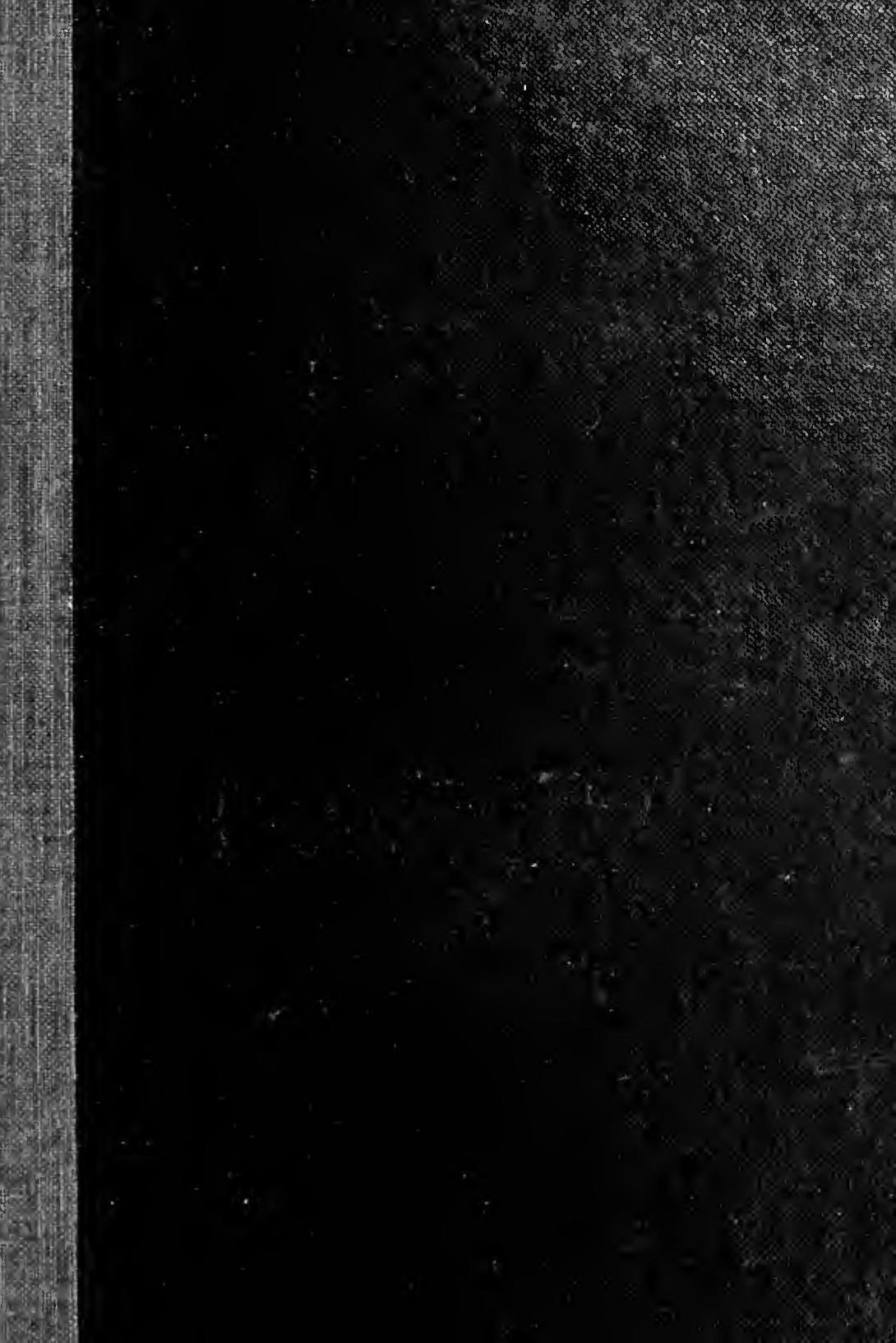




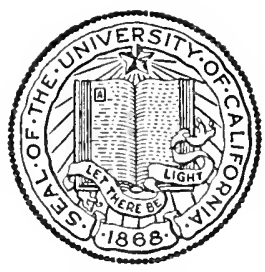

THE LIBRARY

OF

THE UNIVERSITY

OF CALIFORNIA

LOS ANGELES 
Digitized by the Internet Archive in 2008 with funding from Microsoft Corporation 



\section{BRITISH RULE AND JURISDICTION \\ BEYOND THE SEAS}


HENRY FROWDE, M.A.

PUBLISHER TO THE UNIVERSITY OF OXFORD

LONDON, EDINBURGH

NEW YORK 



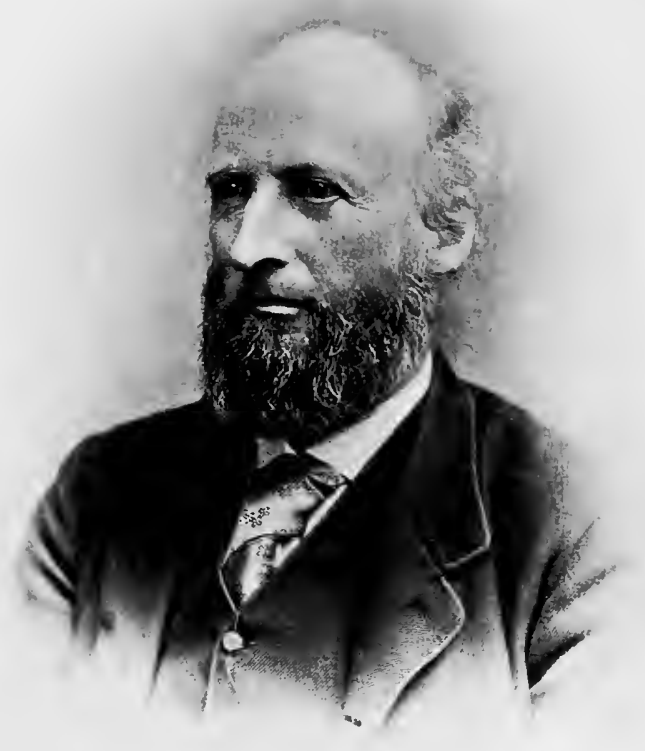




\title{
BRITISH RULE AND JURISDICTION \\ BEYOND THE SEAS
}

\author{
BY THE LATE \\ SIR HENRY JENKYNS, K.C.B. \\ WITH A PREFACE BY \\ SIR COUR'TENAY ILBER'T, K.C.S.I.
}

OXFORD

AT THE CLARENDON PRESS

1902 
OXFORD

PEINTED AT THE CLARENDON PRESS

BY HORACE HART, M.A.

PRINTER TO THE UNIVERSITY 


\section{P R E F A C E}

A pathetic interest attaches to this volume. It was to have been the firstfruits of its author's wellearned leisure. Its completion was arrested by his untimely death.

Henry Jenkyns was born at Durham on September 2, 1838, and was the eldest son of the Rev. Henry Jenkyns, D.D. His father had been a Fellow of Oriel in the timo of Arnold, Copleston, and Newman, and afterwards became Canon of Durham and Professor of Divinity and Ecclesiastical Literature in the Durham University. His mother was the eldest daughter of the Right Hon. Henry Hobhouse of Hadspen House, Somerset, who was permanent Under Secretary of State for the Home Department from I8I7 to I827. He was a nephew, on his father's side, of Richard Jenkyns, the well-known Master of Balliol, and, on his mother's side, of the present Lord Hobhouse. Lord Thring, whose mother was an elder sister of Canon Jenkyns, was his first cousin, though belonging to an older generation.

Henry Jenkyns was educated at Eton and Balliol. He rowed in the Balliol boat when it was head of the river in 1859 , and was one of the three Balliol men who monopolized the first class in Literae Humaniores in the Easter T'erm of June, I860, the 
other two being Chaloner Chute and Lionel Tollemache. After taking his degree he went up to London to study for the bar, and began by reading with a conveyancer at Lincoln's Inn. After spending six months or so in the chambers of Mr. John Welch, the special pleader, at the Temple, he returned to Lincoln's Inn and read with Mr. John Wickens (afterwards Vice-Chancellor), whose pupil he remained until he was called to the bar at Lincoln's Inn in I863. He had some practice as a conveyancer, and occasionally went on circuit, but he very soon left the highway of the legal profession for that special branch of legal work which was to be the occupation of his lifetime. He was entrusted by the Statute Law Committee with the duty of preparing a Chronological Table and Index to the Statutes of the Realm, a task which involved enormous labour and the most minute research into the contents of the statute-book. The first edition of the work appeared in January, I870. When the office of Parliamentary Counsel to the Treasury was ereated in February, 1869, with Mr. Thring as its head, Jenkyns was offered and accepted the post of Assistant Parliamentary Counsel. He held that office until Lord Thring's retirement in July, I886, when he succeeded his former chief. He retired in February, I899, after thirty years' service under the Government. In 1877 he married Madalene Sabine Pasley, youngest daughter of Admiral Sir T. Sabine Pasley, Bart., K.C.B. He was made a C.B. in I882 under Mr. Gladstone's government, and a K.C.B. in 1892 under the 
government of Lord Salisbury. He died, after a brief and unexpected illness, on December Io, I899, within a year from his retirement.

Sir Henry Jenkyns was little known to the world at large. The record of his work is in. scribed on the arid, anonymous, and ungrateful pages of the statute-book, and in the sixty and more folio volumes of confidential papers-drafts, notes, minutes, memoranda, and the like-which testify to his conscientious and unflagging industry.

The period which his official life covered was one of great legislative activity in the British Parliament, and among the many important legislative measures which he drafted, or helped to draft, may be mentioned Mr. Forster's Education Act and Ballot Act, the Army Act of I88I, Mr. Gladstone's Irish Church Act, Irish Land Act and Home Rule Bills, the Acts which transformed the system of Local Government in England and Ireland, and Sir William Harcourt's Finance Act. To make the list complete would be to write the history of English legislation for thirty years. It must not be supposed, nor will it be supposed by any one who is acquainted with the nature of English legislative machinery, that work of this kind was of a mechanical character, or even that it involved nothing more than putting into shape the suggestions of others. The sixty or seventy volumes to which I have referred, if their confidential contents could be disclosed, would tell a very different story. But, from their nature, they cannot be used as materials 
for a biography, nor will any biography be attempted here. All that is attempted is to give the impression produced by a very remarkable man on some of those who knew him best.

It was at the beginning of the year 1870 that I was first brought into close relations with Jenkyns. Mr. Henry Thring, as he then was, wanted a young barrister to give him assistance at his office, and at the suggestion of Jenkyns, whom I knew slightly, I undertook the work experimentally. The experiment, in that particular form, only lasted six months, but during the remainder of the twelve years which elapsed before I went to India I continued to do a great deal of drafting work for the Parliamentary Counsel's Office, and naturally had much to do with the Assistant Parliamentary Counsel. After my return from India in I886 to take up the post which he had vacated, I was intimately associated with him in all his official work.

In personal appearance Sir Henry Jenkyns was a noticeably handsome man, above the ordinary stature, with a powerful frame, strong but clearly chiselled features, and large, dark, expressive, brown eyes. His manners were reserved and sometimes brusque. He had a small circle of intimate friends by whom he was regarded with deep affection. To Ministers and ex-Ministers of the Crown, and in the precincts of Parliament, he was a familiar figure. Among the heads of the Civil Service there was no one who was more frequently consulted, whose opinion carried greater weight, whose 
character commanded more sincere and affectionate respect. But to the world at large he was little known. For this there were many reasons. He was constitutionally shy. He lived the quietest of lives. Even his most intimate friends could not persuade him to dine out. $\mathrm{He}$ abhorred functions. He was the hardest and most indefatigable of workers, and found that he could not reconcile the claims of public duty with the charms of society. Social engagements were incompatible with his method of work, which was to take his papers in the evening to his house in the country, and think out, steadily and quietly, the conclusions which he dictated next morning in the form of memoranda, minutes, or Bills. And lastly, in spite of his robust physique, he had always, from his college days, felt the importance of being careful about his health. His favourite form of recreation was a holiday in the Alps.

For his reluctance to attend public dinners and similar gatherings there was another reason beside that referred to above. He always maintained that a civil servant, especially if engaged on confidential work, should keep in the background, and that the less he spoke in public and wrote for the press the better. It was probably for this reason that during his time of office he made no literary use of the vast mass of materials which he had collected in the course of his official labours. It may be that he was over strict in his self-imposed reticence. But if he crred it was on the side of virtue. The rules which he laid down for his own guidance in these 
matters were the outcome of the stern, lofty, unswerving, austere conscientiousness which was the keynote of his character. No one had a higher standard of public duty. No one lived so conscientiously up to his standard. Private interests, amusements, convenience were, with him, always subordinate and subservient to public duty. If he had a complicated legislative task on hand it absorbed the whole of his time and energies, irrespectively of office hours and vacations. And the level of work which he expected from others never equalled his own.

Probably the first thing that would strike any one who was brought into contact with Sir Henry Jenkyns in his official capacity would be the extent, accuracy, and minuteness of his acquaintance with legislative and administrative machinery. He knew the machine by heart. So far as this knowledge was derived from book-learning it was to be explained by his habits of work. When he was called upon to prepare a Bill on any important subject he would begin by endeavouring to make himself a complete master of the subject in all its bearings. For this purpose he would spare himself no pains in ransacking the contents of statutes, law reports, text-books, blue-books, volumes of Hansard, and the like. The results would be embodied in an exhaustive memorandum, which would describe the existing state of the law, the mode in which, and the sources from which, it had grown up, the authorities by which it was administered, the difficulties which had occurred in its administration, the 
attempts which had been made, in Parliament and elsewhere, to amend it, and the fate which these attempts had encountered, and would end by sug. gesting practical conclusions for adoption, and indicating the arguments for and against each alternative course. The Bill based on these materials would 'be accompanied by full notes, showing the mode in which, and the reasons for which, each clause would alter the law, and the arguments which might be used and would have to be met. The folio volumes to which reference has been made abound in memoranda and notes of this kind. The number of legislative problems with which Parliament has to deal, though great, is not infinite, and the same problems are apt to recur in varying forms. Under these circumstances his years of patient, thorough, and methodical study made him a walking encyclopædia of legislative information, and equipped him for grappling, at a moment's notice, with almost any subject on which legislation might be required, and for offering searching criticisms and useful suggestions on almost any legislative topic. And his knowledge was not derived from books alone. During his long term of office he had mixed with the staff, and become familiar with the actual working, of all the great Government departments; he had enjoyed exceptional opportunities of studying from the inside the ways of Ministers and of Parliament; he knew what legislative experiments had been tried and suggested, why some of them had failed and others had never come to the birth; and he could 
often divine in what quarters, and on what grounds, criticism and opposition might be expected. It may be added that he was, in a small way, a landowner in two counties, and, as such, took a keen interest, and a practical ipart, in working out the problems of rural administration. His practical experience of these matters served him like Gibbon's experience in the militia.

His knowledge of detail was only equalled by his grasp of principle. As a constitutional lawyer he ranked very high, for not only had he an exceptional acquaintance with the actual working of the British constitution, but he had carefully studied its historical development, and made himself familiar with the constitutions of foreign countries and of other parts of the British Empire. And though his practice at the bar had not been extensive, yet, within the domain of private and criminal law, he was a very sound lawyer, and had, what practising lawyers do not always possess, a firm grasp and clear appreciation of legal principles. This was due to the habit of looking at legal questions not merely from the legal, but from the legislative, point of view, and of considering not merely what existing legal rules are, as established by judicial decisions, but how they might be and ought to be modified and developed. And his mind, which was by nature of a judicial cast, had been carefully trained in the habit of weighing and balancing rival considerations, and arriving at an impartial and practical conclusion.

These were the qualities which made his advice 
and criticism so useful to Minister's. A new post, like that of Parliamentary Counsel to the Treasury, is apt to be very much what the holder chooses to make it. Jenkyns' view of his functions was that he was not merely a draftsman, but counsel to the Government in its legislative capacity, and that it was his duty, as such, to bring forward and press any considerations within his knowledge and experience which might assist a Minister in arriving at a sound conclusion, always remembering that it was for him merely to present arguments, and that the responsibility for decision must rest with the Minister himself. To perform this task with effciency and discretion is not easy. The adviser has often to play the part of Devil's advocate, and to insist on difficulties which the sanguine legislator would prefer to ignore. It is easier to prophesy smooth things, and sometimes more profitable. Micaiah the son of Imlah was not popular in high quarters. The extent and variety of Jenkyns' constitutional knowledge and Parliamentary experience made him a formidable critic of legislative proposals, and the frankness and outspokenness with which lie expressed and supported his views, coupled with a certain brusqueness of manner, sometimes gave offence. But those whom his criticism irritated for the moment were usually ready to acknowledge its permanent value later on. And it was not a merely negative and destructive criticism. He was always eminently suggestive and resourceful. He possessed, what is perhaps the most valuable of all qualities for legislative purposes, a constructive 
imagination. He saw administrative machinery in the concrete. He knew not only the law which would have to be applied, but the kind of men who would have to work it, and the human weaknesses, prejudices, and interests which it would bring into play. Hence he could sketch out with great rapidity the heads of a scheme which, though requiring modification in details, would probably be found workable in its main outlines. His feeling for artistic form and literary finish was not strong, and his style was sometimes open to the charge of being rugged and crabbed. But the machine which he turned out, unless thrown out of gear during its passage through Parliament, usually stood the test of practice. The main object had been clearly conceived, the details had been thought out, the parts cohered, the joints were well morticed.

It need hardly be said that his zeal and energy were bestowed irrespectively of political parties. He laboured as indefatigably on Mr. Ritchie's Local Government Bill for England and Mr. Gerald Balfour's Local Government Bill for Ireland as on Mr. Gladstone's Home Rule Bills and Sir William Harcourt's Finance Bill. And there are occupants of the opposition Front Bench who can testify that his criticisms of weak points in legislative proposals were at least as unsparing during their period of office as in the time of their successors.

What he was to his official superiors, that he was to those who worked with him and under him. They also can bear witness that, if he was the most searching, he was also the most helpful and.con- 
siderate, of critics; that while he was always anxious to get to the bottom of things, he was never content with merely finding fault and pointing out omissions, but was unfailingly ready to bring to their assistance his sound, sane, and upright judgement, and his unrivalled store of knowledge and experience. To co-operate with him in his work was a moral and intellectual discipline of a very high order.

He has left his mark deeply and permanently on the Victorian Statute Book. As a draftsman he had to recognize and bow to the Parliamentary exigencies which controlled his craft, but no one ever struggled more conscientiously, more persistently, or more effectually, to remove or minimize the defects of form incidental to Parliamentary legislation. He was substantially the author of the Index which is an indispensable guide to the laby. rinth of our statutes. He was the life and soul of the Statute Law Committee, and lived to see tho completion of the work of expurgation and revision which is represented by the Revised Edition of the Statutes, and he was indefatigable in urging the importance, and giving practical aid to, the work of Statute Law Consolidation.

Of his private life this is not the place to speak. His friends will remember him as a man of stainless honour, justus et tenax, tho most loyal, fearless, and single-minded of public servants, the most conscientious but genuinely kind of friends.

I append to this imperfect sketch of an old friend's character and career some appreciations written after his death. 
Lord Thring has contributed the following note on his early official career :-

In 1869, Mr. Lowe, then Chancellor of the Exchequer, created the office of Parliamentary Counsel, and appointed me to the post. Looking about for assistance, I could think of no one who would be of any possible use except Mr. Jenkyns. Accordingly I informed Mr. Lowe that I should require an assistant counsel, and that I should name Mr. Jenkyns, adding that he was my first cousin, and that possibly his nomination might be considered a job. To which Mr. Lowe replied with characteristic quickness, 'I do not care whether he is your first cousin or not; I am sure you would not appoint an inefficient man.'

Thereupon Mr. Jenkyns was appointed, and worked as my assistant till I resigned my office on being made a peer in I 886.

During the whole of those sixteen years I was in daily nay hourly intercourse with Jenkyns. In his work he was most accurate and industrious, never sparing his toil. His mind was of the best legal type: he understood law profoundly, forming a just opinion on any legislative difficulty which might arise, but above all having the rare qualification of a ready invention in devising means for surmounting each difficulty instead of merely pointing out its existence-an easy task within the eapacity of many lawyers who lack altogether the knowledge and ability necessary to suggest a remedy.

Whilst I was head of the office, Jenkyns had not often an opportunity of undertaking independently important measures, but I recollect several notable exceptions. In $1870 \mathrm{Mr}$. Forster, who was engaged in the preparation of the Elementary Education Act, I 870, entrusted the Bill to Jenkyns; and accordingly the whole of that most important measure, the foundation of our system of elementary education, was entirely drawn by him. The strain put on him was tremendous, and for a short time his health broke down and he had to moderate his work at the office.

Sir Henry James, now Lord James of Hereford, also selected 
him to draw his great measure for the Prevention of Corrupt Practices at Parliamentary Elections (the Corrupt and Illegal Practices Prevention Act, I883), and formed the highest opinion of his ability.

Sir William Harcourt also 'requisitioned' him for the preparation of a Bill, in which he was much interested, for the government of London.

Jenkyns had a very just objection to civil servants endeavouring to procure credit for themselves by writing articles on general subjects in magazines, or otherwise exhausting their energies in tasks not incident to their professional duties. On the other hand, he shrank from no labour which, though not obligatory on the office, was conducive to the public good.

In July, I 879, Colonel Stanley, the Secretary of State for War, requested the Parliamentary Counsel Office to prepare rules of procedure under seetion 69 of the Army Discipline and Regulation Act, I879, and to superintend the preparation of a Manual which should contain an edition of the set and of the rules with notes, and form a text book of Military Law.

To this book Jenkyns contribnted four distinct ehapters or essays : I. 'On the History of the Military Forces of the Crown,' requiring great research. 2. 'On Enlistment.' 3. 'On the Condition of the Military Forces of the Crown.' 4. 'On the Relations of Soldiers to Civil Life.' Besides this, he aided the editor in the composition of several other chapters, and rendered invaluable assistance in generally looking through the work and revising its contents.

In the work of Legislative Reform he was indefatigable.

The Statute Law Revision Committee would have had great difficulty in carrying out their labours had not Jenkyns constantly assisted them by his advice, and managed the details of their business.

He was also a member of the Committee appointed by Lord Halsbury in 1885 to superintend an edition of the Reports of State Trials, berinning with the year 1820-the date of the conclusion of Howell's well-known edition of State Trials-and brought down nearly to the present time.

Here again he was the life and soul of the Committee, and 
undertook for the Committee that kind of practical business which is too often, in spite of its great importance, delegated to the secretary.

I mention these matters, as they display his character before he became head of the office, and show his complete indifference to self-glorification or any other motive save that of doing his duty to the public.

As a subordinate he was most loyal to his chief: for although of a resolute temper and firm in his own opinion, he would when overruled endeavour to carry out his chief's view in the best way he could, without doing as so many men of inferior mind do, sulking and endeavouring to persist in their own way to the detriment of the head of the office, on whom the responsibility rests.

As a friend he was steadfast and faithful, and at the close of my long and laborious life I am proud (as an eminent statesman justly said I ought to be proud) of having introduced into the public service a man who devoted his whole life to the performance of his duty, and when he became the head of the office displayed the most conspicuous ability in the management of the Government Parliamentary business.

I have only spoken of Jenkyns as he was when my assistant, and when he had comparatively little opportunity of becoming lnown to ministers or to the public. It is for others to tell of the great influence he had on public affairs when he succeeded to my post and became the adviser of the Government in respect of the measures passed from the year I 886 till the yesir 1899 , when he resigned his office.

September 3, I900.

THRING.

The following are extracts from private letters :From Mr: John Morley'.

I am heartily glad to learn that even a fragmentary memorial of Jenkyns is to be given to the public.

It can furnish only a most inadequate idea of that remarkable character, but it will be better than nothing, and perhaps 
we can say no more, and not always as much, of ambitious memorials in bronze and marble. As you know, it was my fortune to be in close contact with him in several laborious and diffieult pieces of public business, and more especially in the preparation and working of the Irish Government Bill of 1893 . That project took us in greater or less degree over the whole field, and there was no single point or part of it, constitutional, financial, or administrative, where Jenkyns failed to show himself a consummate master of his trade. His knowledge of administrative practice was never at fault; his store of case and precedent was of the richest; in meeting the endless iropia that rise in every large and comprehensive bill he abounded in skill, in ingenuity, in resource. The only man in my experienee at all comparable to him in the difficult art of rapidly devising the right words for the bare rudiment and intention of a clause or an amendment was Herschell, and Jenkyns was at least as clever in turning a sharp corner. Again, while his vast experience had given him an acute insight into the points that might be raised against you, in the House or elsewhere, nobody that ever lived can have had less in common with that most tiresome variety of the human species which delights in always starting difficulties and parading objections. On the contrary he started with the assumption once for all that the thing must be done, and it was for him to help in getting it efficiently done. His thoroughgoing veracity and faithfulness, alike as man and workman, prevented him from ever giving lazy or compliant assents. I have seen him more than once stand against all Mr. Gladstone's driving power (which was no joke), and I have heard stories of his blunt speech in other cases. Nobody that I have ever lnown was more absolutely free from the faintest tinge of egotism or touchy self-consciousness. I remember, in the case of some Irish land bill, saying to him that I thought I would bring over a certain Irish lawyer with much knowledge of such things to help us. Jenkyns himself was a very old and skilful hand in that entangled branch of legislative industry, but he cordially agreed that a native expert might find out weak plaees, and he welcomed him accordingly. He seemed never to think of 
himself at all, any more than we can suppose a swift and powerful locomotive to think of itself. To make the journey as safely as the state of the road, the cabinet gradients, the force and direction of the parliamentary wind, would allowthis was all that concerned him. He struck me as thinking praise and blame, appreeiation of his work by others or disappointment at it, really no concern of his. The work itself, knowledge extended, duty done-that was what he cared about. His power of work was immense, and his industry unflagging. And work was no passive or receptive makebelieve; he was using an active, vigorous, and searching mind all the time. I know that there are some who question the superiority of new maxims of draftsmanship over the old, but this is a quarrel into which I do not enter. I only wish in all humility and sincerity to tell you some of the impressions made upon me by the high qualities and rare attainments of this zealous and altogether admirable public servant.

From Mr. Arthur Balfour ${ }^{\top}$.

... I have always admired the ability and zeal which he brought to the discharge of public duties of a most difficult and delicate nature. A most acute critic of other men's ideas, rich in suggestions of his own, with unrivalled experience and great legal knowledge, he was possessed of the gifts which go to make a public servant of rare exeellence. I deeply regretted his abandonment of public life....

From Sir Francis Mouatt ${ }^{1}$.

... We have lost in your husband the most distinguished civil servant of his time, and I declare to you that looking back on forty-two years of a Treasury life, I know of no man to whom the State owes a deeper debt of gratitude than Sir IIenry Jenkyns....

From Sir E. Hamilton '.

I was his colleague in the public service for nearly thirty years: and I have often said, that if I were to classify in 
order of merit the many public servants with whom during that period I have come in close contact, I should unhesitatingly place him at the top of the class. His grip of the difficult and raried subjects with which he had to deal was unique: and one always felt safe in his hands. ... There could not be a more pleasant or more considerate or more forbearing man to do business with. ...

\section{From Lord Welby ${ }^{1}$.}

... For years he has been my beau ideal and type of the Civil Service. Few civil servants could hope to rival his abilities. ... He knew exactly how to combine independence, and fearless expression of his opinion, with the due subordination which a civil servant owes to his political chief. His ability was daily impressed upon us, no less than his unfailing good temper, openness of mind, and ripeness of judgement.

I used to wonder how a man who lived so little in the world had become so complete a man of the world.

\section{From Mr. James Bryce?}

... the longer I knew him, the more I admired not only his great abilities, perhaps unequalled in the whole Civil Service, but his high sense of duty, his perfect truthfulness and uprightness, his unfailing public spirit, his strong attachment to all good causes and sound principles. It was an unceasing pleasure to meet him and discuss any subject with him; one always came away knowing more, and having got a better insight into the essenee of a question. He used to seem to me the most powerful arguer I knew; and he never argued but for truth.

It remains to say a very few words about the circumstances under which the following pages were written.

Jenkyns had always intended to employ his leisure after his retirement in giving shape and form to some of the papers which he had written in the 
course of his official work. He began with some notes on colonial questions, worked hard at them for several months, and hoped and believed that they would be ready for the press by the end of I899. The nine chapters of which the book was to consist were, in fact, complete at that time. But they naturally required careful examination before they could be safely entrusted to the printers, and I undertook their revision, with the help of Mr. Graham-Harrison, who had assisted Jenkyns in their preparation. Whilst this work was in progress the Act which established the Australian Commonwealth became law. It seemed impossible to ignore an event of such cardinal importance in the colonial world, but any adequate reference to it involved drastic alterations in the chapter on Selfgoverning Colonies. The perspective had been changed; the proportions allotted to different parts of the subject required shifting; details about the constitution of the Colonies which had now become States of the new Commonwealth could be more appropriately relegated to an appendix. This being so, it was considered desirable to rewrite the chapter, and this task was entrusted to Mr. J. A. Simon. For Chapter IV in its present form he is exclusively responsible, although it is partly based on the materials supplied by Sir Henry Jenkyns. In the other chapters I have made only such verbal and formal alterations as would have been made by the author, if he had had an opportunity of revising his proof sheets. Such few additions as I have made are indicated by square brackets. 
The title of the book had not been settled, and it was necessary to find something which would include not only Colonies and Dependencies, but Protectorates and the exercise of British Jurisdiction in foreign countries. I hope that the title crentually selected sufficiently indicates the scope of the work.

C. P. ILBERT.

3 Whitehall Gardess,

February, I902. 


\section{CONTENTS}

Chapter Page

I. Classes of Territories under British JurisDICTION

II. Relations between Home Government and Colonial Governments . . . . 10

III. British Possessions other than Colonies · 37

IV. Self-Governing Colonies • . . $\quad 54$

V. Colonies not Self-Governing • • . 9 I

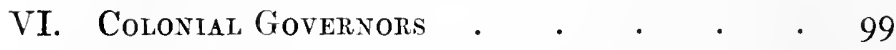

VII. Extra-Territorial Jurisdiction • . . 123

VIII. Consular Jurisdiction . • . . . . $\quad$ I 48

IX. Jurisdiction in British Protectorates and the Position of Foreign Subjects in them 165

\section{APPENDICES}

I. Self-Governing Colonies . Between pp. i96-7

II. Non-Self-Governing Colonies . $\quad$. 197

III. British North America Act, i 867, ss. 91-95, with some Judicial Decisions thereon • 199

IV. Governors' Commissions . . . . $\quad 213$

V. Colonial Laws Validity Act, i865 • • 239

VI. Mr. Scott Hope's Memorandum on British Jurisdiction in Foneign States . . 242

VII. Foreign Jurisdiction Act, 1890 • • . 267

VIII. Early Constitutional History of the Australian Colonies . . . . . 276

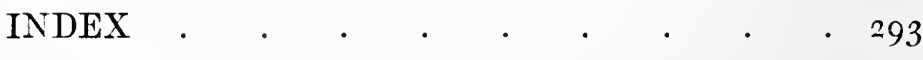




\title{
BRITISH RULE AND JURISDICTION BEYOND THE SEAS
}

\author{
CHAP'TER I \\ CLASSES OF TERRITORIES UNDER BRITISH \\ JURISDICTION
}

The countries or communities outside the United Kingdom, Crr. I. within which British jurisdiction is exercised, may be classed under three heads :

(1) British possessions;

(2) British protectorates ;

(3) Countries or communities outside those possessions and protectorates.

What is now termed a sphere of influence is a portion of a non-Christian or uncivilized country, which is the subject of diplomatic arrangements between European states, but has not yet developed into a protectorate. It comes, therefore, under the third head.

Countries or communities under the first two heads are both in a sense dependencies of the United Kingdom, though some of the self-governing colonics will hardly come within the meaning of dependency as used by Sir George Cornewall Lewis ${ }^{1}$.

It is preferable, therefore, to use the popular, and to somo extent technical, expressions, 'British possession' and 'protectorate,' rather than an expression like dependency, to which authors have hitherto attached different special meanings.

1 Lewis, Gov. Dep. (cd. by Lucas), p. 4, and note $\Lambda$. 
Cн. I. 'British possession' is recognized by a recent Act ${ }^{1}$ as being the technical legal term for every part of the King's possessions. dominions outside of the United Kingdom, which forms a separate community, and has a local legislature of its own, but the Act goes on to explain that where several communities, each of which has a local legislature of its own, are under' a common central legislature, the expression 'British possession' is to be treated as including all those communities as if they were one community.

Thus a British possession may consist of a country which, if it were not part of the British dominions, would be by itself an empire with dependencies, such as British India, or of a federation of states, such as the Dominion of Canada, the Commonwealth of Australia and the Leeward Islands.

Colonies. 'Colony' is now a term used, both technically in Acts of Parliament ${ }^{2}$ and popularly, to include every British possession except the Channel Islands, the Isle of Man, and British India. It thus includes not merely communities formally declared to be colonies, but those which used to be termed plantations, islands, territoriès, settlements, dominions, forts, or factories, and in fact, with the above exceptions, includes every community outside the United Kingdom which is part of the British dominions, whether acquired by settlement or by conquest or cession.

As above pointed out, a country like Canada, which, if not under the British Crown, would be a federation of states, forms one single colony, just as does the little community of the Falkland Islands ${ }^{3}$. And the self-governing colonies, the distinction of which from Crown colonies is pointed out below ${ }^{4}$, approach the position of independent states.

Boundaries of possessions. As a general rule, the British dominions cannot be added to or diminished without the consent of the Crown. Whether

${ }^{1}$ Interpretation Act, 1889 (52 \& 53 Vict. c. 63 ), s. 18.

${ }^{2}$ See ibi, s. 3 .

3 As to the meaning and derivation of colony, see Lewis, Gov. Dep., pp. II 4 , 168 E, I 74 ; Adam Smith, Bk. iii. ch. vii. part i.

4 See pr. 7 seq., and eh. v. pr. 98, 99. 
the Cromn ean, except for the purpose of concluding a war, Си. I. surrender British territory without the consent of Parliament, is a moot constitutional question ${ }^{1}$. The answer would depend largely upon the circumstances of the surrender, but in this, as in most other constitutional questions, the modern tendeney is to consider that the Crown could not do so important an act without the consent of Parliament?

In India, territory is not unfrequently annexed or surrendered by the Governor-General ${ }^{3}$. But the ease of India, with its dependent states, is exeeptional, and ean hardly be cited as a precedent for the surrender of territory in other cases.

In the ease of other British possessions, the boundaries are determined or altered by Order in Comncil or Letters Patent under the Great Seal of the United Kingdom, and are sometimes fixed by or under the direct authority of an imperial Act.

Where an imperial Act has expressly defined the boundaries of a colony or has bestowed a constitution on a colony within certain boundaries, territory eannot be annexed to that colony so as to be completely fused with it, as e.g. by being ineluded in a provinee or electoral division of it, without statutory authority; because-

(a) Any such annexation wonld be altering an Aet of Parliament; and

(b) Colonial legislation cannot operate beyond the colony, and therefore cannot extend to the new territory until it is by some means made part of the colony.

But the King, unless restrained by an imperial Aet, can give to any such colony as above mentioned, and the colony can arcept, the administration and government of any territory; and the most solemn mode of such acceptance is

3 See Forsyth, Cases and Opinions on Constitutional Law, p. 182.

2 See the debates on the cession of IIeligoland in 1890 (Hansard, ecexlvii), a d the Anglo-German $\Lambda$ greement $\Lambda$ ct, 1890 (53 \& 54 Vict. c. 20).

"Seo Ilbert, Gocemment of Indiat, P. 210. 
Cir. I. colonial legislation. In such a case the territory is not incorporated with, and does not become part of, the colony, but is only administered by the same Government.

The same law appears to apply where the boundaries have been fixed by Order in Council or Letters Patent issued in pursuance of statutory authority ${ }^{1}$; and where the boundaries of a colony are altered by diminution. Where a colony, whether self-governing or not, has received a constitution by Letters Patent or Order in Council without any imperial Act, it is competent for His Majesty to grant, and for the colony to accept, variations of the constitution, and, amongst others, an enlargement or diminution of its territory. Of such acceptance a colonial Act is the most solemn expression.

An annexation, even if irregular in the outset, may possibly, if followed by a de facto incorporation for a long period of time, acquire, like other constitutional changes, validity through usage.

In other cases irregular annexations liave been validated by a resort to Parliament ${ }^{2}$. In 1895 a general Act was passed ${ }^{3}$ enabling the Crown, by Order in Council or Letters Patent, to alter the boundaries of any colony, but this power was limited in the case of self-governing colonies by requiring the consent of the colony.

Distinc- The colonies differ according as they have been acquired tion between settled and conquered or ceded colonies. by settlement or by conquest or cession, and the courts of law have sometimes been called upon to decide whether a colony was a settled or a conquered colony. The distinction appears to depend upon whether at the time of the acquisition of any territory there existed on that territory a civilized

' e.g. $5 \& 6$ Vict. c. 76 ; or Order in Council under $50 \& 51$ Vict. c. 54 , s. 2.

2 See for example as to the boundaries of New South Wales and Victoria, I 3 \& I4 Vict. c. $59 ; 18$ \& 19 Vict. c. $54 ; 24$ \& 25 Vict. c. 44 : of Canada, 30 \& 3 I Vict. c. 3, s. $6 ; 34 \& 35$ Vict. c. 28.

${ }^{3} 58$ \& 59 Vict. c. 34. [This Act does not apply to the colonies which are states of the Commonwealth of Australia, but the Commonwealth as a whole is a self-governing colony within the meaning of the Act ( $6_{3} \& 6_{4}$ Vict. c. $[2$, s. 8).] 
society with civil institutions or laws, whether in fact there Crr. I. existed anything which could be called a lex loci ${ }^{1}$.

As regards a settled colony, the principle is well established Settled that an Englishman carries with him English law and liberties into any unoccupied country where he settles, so far as they are applicable to the situation having regard to all the circumstances.

Consequently, apart from statute law, no legislature can be established in a settled colony by the Crown, except one which comprises a representative body having powers of taxation. Nor ean the Crown legislate for it by Order in Council or otherwise ${ }^{2}$.

It was found necessary to alter this rule by statute, in cases where the settlements are so small, or have so large a subject population, that the ordinary representative institutions are unsuitable, and to give power to the Sovereign in Council to legislate for the settlement, and to delegate the power of legislation to three or more persons within the settlement.

This power was first given by an Act of $x 843^{3}$, with reference to the settlements on the coast of Africa, and the Falkland Islands, and was extended by an Act of $1860^{4}$ to other British possessions. Owing to some doubts as to the application of these Acts in certain cases they were repealed and superseded by an Act of $1887^{5}$. The provisions of the Act of 3887 extend to every British possession nat acquired by cession or conquest, and not for the time being within the jurisdiction of the legislature (constituted otherwise than by virtue of the Act of 1887 , or of either of the two Acts which it repeals) of any British possession.

The Act allows the legislative power to be delegated either by an instrument under the Great Seal or by instructions under

1 e.g. Jamaica and St. Helena, R. v. Vaughen, 4 Burr. 2494; and Cumptell v. Hall, 20 St. 'Tr. 239, 290, 30r, 326, 330. See 2 Pecre Williams (1 722), 1. 75 ; Freman s. Fairlie (1828), I Moo. Ind. App. 305 ; and 'larring, Leto relating to the Calonies, 1. 30 .

${ }^{2}$ Camplell $v$. Hall, 20 St. 'Tr. 239, 292.

$36 \& 7$ Viet. c. 13.

s The British Settlements $\Lambda$ et, 1887 (50 \& 51 Viet. c. 54). 
Cr. I. the Royal Sign Manual, and also allows civil or criminal jurisdiction, original or appellate, respecting matters within the settlement, to be rested in the court of some other British possession.

As in the case of a settled colony the Englishman takes his law with him, the fundamental law, or as English lawyers would say, the common law, of every such colony is the English law as existing at the date of the settlement, or as modified by subsequent legislation of the imperial Parliament, expressly or by necessary implication extending to that colony. The date at which the English law so applying is to be ascertained has been in many cases fixed by local legislation. In other cases, legal decisions have been given that English Acts or legral rules are inapplicable under the circumstances of the colony ${ }^{1}$.

Law in

In the case of a conquered or ceded colony, the Crown has

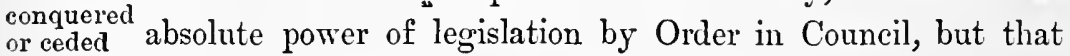
colony. power may be surrendered either by cstablishing or authorizing a governor to establish a representative legislative assembly or otherwise, or, if expressly reserved, may be exercised concurrently.

In a conquered or ceded colony, the law existing before the conquest or cession is usually presumed to continue until altered ${ }^{2}$, and therefore forms the common law. But it is necessarily affected by the introduction of the law of the conqueror as regards administration, appellate jurisdiction, matters connected with the exercise of the sovereignty, or matters of universal policy, e.g. navigation or slave trade. Moreover, any laws contrary to the fundamental principles of English law, e.g. torture, banishment, or slavery, are ipso facto abrogated ${ }^{3}$.

1 See Acts and cases cited in Tarring, op. cit., pp. 6-1 I.

2 Campbell v. Hall, 20 St. Tr. 239, 323, 330. 'The king's power is subject to that of Parliament, and must be in accordance with fundamental principles' (ibid.).

3 See Fabrigas r. Mostyn, 20 St. Tr. 82, 18r. See also Parl. P. as to Hong Kong, C. 3185 of 1882 ; Picton's Case, зо St. Tr. 225 ; Hill v. Eigge, 4 St. Tr., N. S. 723, and cases in Forsyth, Cases and Opinions on Constitutional Law, eh. 3 . 
After the legislature is established, the Crown is in the Crr. I. same position in respect of the colony as it is in the United Kingdom; and indeed, before that establishment, the Crown must follow English law, and therefore cannot create a court with jurisdiction unknown to English law ${ }^{1}$.

There is mueh variety in the instruments of constitution of Instruthe colonies. Such instrument may be an imperial statute, ments of an Order in Council, Letters Patent, a colonial Act or ordin- tion. ance, a governor's commission, or a combination of all these ${ }^{2}$.

There are many methods in which a colony or possession Modes of may be retained in political connexion with the mother $\begin{gathered}\text { governing } \\ \text { colonios. }\end{gathered}$ country.

At one end of the scale is absolute government, where the chief executive officer is appointed by the mother country, with or without councillors so appointed, and in which the inhabitants are kept in subjection either by force, by interest, or by the habit of submission. In such a case, the mother country regulates all the domestic law and institutions.

At the other end is absolute freedom, where the mother country regulates foreign affairs, but all domestie institutions, civil, moral, and religious, are regulated by the inhabitants of the colony itself.

Before the secession of the United States of Ameriea, a system of representative government was commonly adopted. The colonies were considered rather as helps to the trade of England than in any other light. The govermments were distinguished indeed as being royal, proprietary, or chartered, but in all three there was a House of Assembly elected by the people, and a couneil locally appointed helped the Governor in executive and judicial duties. The laws required the assent of the Governor and ratification of the Crown in Council; but in practice the colonies were left, as regards domestic matters, to govern and tax themselves. Representative

1 See In re Bishop of Natal, 3 Moo. P. C., N. S. 115.

2 See Parl. P. 1889, No. 70 (vol. lv. p. 71), and 189o, No. 194 (vol. xlix.

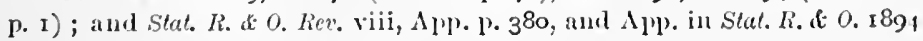
and 1897 , and ch. iv infril. 
Cн. I. government was not usually granted in express terms, but was assumed by the colonists as a matter of right. England merely regulated external commerce and external affairs. The distinction between the three classes of government depended upon whether the Governor was appointed by the Crown - or by a proprietor (whether an individual or a company), or was left to be elected by the representative assembly, the government in such last case being a pure democracy?

A departure from this system largely contributed to the revolt of the thirteen American colonies, and after their complete separation a change of opinion began. Nova Scotia indeed had previously obtained a constitution, but the other colonies had not. New Brunswick obtained one in 1785 , Upper and Lower Canada in I79I ; but the constitutions so granted reserved greater power to the Home Government than did the old constitutions. In Australasia, colonies ${ }^{2}$ have been founded with prospective constitutions, i.e. constitutions to be established hereafter.

Self- None of these constitutions made the colony self-governing governing
colonies. they did not leave the administration of the local government to executive ministers, who are responsible to and dependent on the confidence of the colonial legislature, but left it to ministers responsible to and dependent on the will of the Governor only.

Until I846, no colony was a self-governing colony with responsible government, though at that time the majority of the colonies had legislatures, with an elective assembly having taxing powers; but in all, the executive administration was carried on by the Governor, with the aid of a council, the members of which were nominated by and responsible to him alone ${ }^{3}$.

The change from that kind of government to responsible

\footnotetext{
1 Merivale, Lectures on Colonization and Colonies, vol. i. p. 88.

2 e. g. South Australia and New Zealand.

3 Merivale, C. \& C. (186I ed.) p. 636 .
} 
government requires no legislative authority, as it depends Cr. I. merely upon instructions given to the Governor as respects the choice of the executive ministers ${ }^{1}$. Those instructions were given, and responsible government was introduced into Canada in I 846 , and into the other North American colonies between that date and 1855 , Newfoundland being the last.

But though responsible or cabinet government was then introduced, the colony had not the same amount of independent power which it possesses now. Sir George Cornewall Lewis, in $184 \mathrm{I}^{2}$, wrote that 'if the Govermment of the dominant country substantially governs another country, the representative of the latter country does not govern '; and that 'a self-governing dependeney, supposing the dependency not to be virtually independent, is a contradiction in terms.'

If Sir George Cornewall Lewis eould now study the selfgoverning eolonies, he would not have made this statement, or at any rate would not have made it in such a broad form.

Not only has each of the Australasian colonies obtained responsible government, and become a self-governing colony, but so also have Cape Colony and Natal, in each of which there is a large coloured native population of an uncivilized character, without votes.

The result is that the position of a self-governing eolony approximates more to that of the early American colonies; but its relation to the mother country is less of a protective and more of a federative eharacter. With colonies which are not self-governing, the position is in no respect that of an independent protected state, but varies from that of absolute government by the mother country to relations approximating to the federative character of the self-governing eolonies.

Hardly any two colonies stand in the same relation to the mother country. At one end are the self-governing colonies, nearly independent; at the other are the Crown colonies, in the narrowest sense, entirely governed by a grovernor appointed by the mother country.

1 See below, ch. iv. 1. $5^{6 .}$

${ }^{2}$ Gov. Dep., p. 296. 


\section{CHAPTER II}

\section{RELATIONS BETWEEN HOME GOVERNMENT AND}

COLONIAL GOVERNMENTS

Сн. II. THE links which unite every British possession to the

Links between mother country and British possessions.

(a) Parliament. mother country, and indeed to the rest of the British dominions, are two-the legislative link of the imperial Parliament, consisting of the Crown, Lords, and Commons, and the executive and judicial link of the Crown.

The legislative supremacy of Parliament over the whole of the British dominions is complete and undoubted in law ${ }^{1}$, though for constitutional or practical reasons, Parliament abstains from exercising that supreme legislative power.

Thus, as respects taxation, Parliament expressly abandoned the right to $\operatorname{tax}$ ' $H$ is Majesty's colonies, provinces, and plantations in North America and the West Indies,' except for the regulation of commerce, the net produce in that case to be applied for the use of the colony ${ }^{2}$. And now it is a recognized constitutional rule that Parliament will not impose a tax on any British possession, and that the direct control of the finances of a possession rests with the Government of the possession ${ }^{3}$. This doctrine is quite consistent with the very effective indirect taxing power and financial control which, as will be mentioned below, is exercised in

1 This was challenged in former days, see Lewis, Gor. Dep., pp. 92, 156, 348 , and Sir S. Romilly quoted in Lewis, p. 240 , but was declared by 6 Geo. III. c. 12 , and is now unquestioned. Campbell $\mathrm{v}$. Hall, $20 \mathrm{St}$. Tr. 239, 304, 323. But as to the ChanneI IsIands, see below, ch. iii. p. 37 .

${ }_{2} \mathrm{I} 8$ Geo. III. c. I2 ; ef. Dicey, Lav of the Constitution, p. 63.

3 See, however, below, ch. iii. pp. 39 seq., as to the Isle of Man and British India, and ch. v. p. 95, as to Malta. 
practice by the Home Government over British India and Cн. II. the Crown colonies.

If Parliament were to violate the constitutional rule, and impose a tax upon a colony, that tax would be valid in law, and colonial and imperial courts would feel compelled to give effect to it. And oceasionally in some exceptional eases, such as colonial lighthouses, a charge very similar to a tax is in fact imposed by the authority of the imperial Parliament, and ean thus extend to and be collected in British possessions.

Besides abstaining from taxation, the imperial Parliament, for reasons partly practical ${ }^{2}$ and partly constitutional, never legislates for the internal government of a possession, except where imperial policy is affected or imperial subjects are dealt with, so that the legislative control over internal affairs rests with the legislature of the possession.

Moreover, there is a constitutional understanding that any imperial legislation which affects a self-governing colony, shall, except where imperial subjects are concerned, be only enacted after communication with the colonial Government ${ }^{3}$.

The local Government of a possession will in some instances apply for imperial legislation, as for instance where the constitution is regulated by imperial Aet, and requires modification or explanation, or where some doubt has arisen as to the validity of colonial legislation, or where there is need for a law extending to more than one colony 4 .

1 I8 \& I9 Viet. e. 91, ss. 2-6, re.enacted in 57 \& $5^{8}$ Viet. e. 6o, s. 670; and as to Basses light in Ceylon, $35 \& 36$ Viet. c. 55 .

${ }^{2}$ See Lewis, Gor. Dep., pp. 82, 198, 240, 348.

"Thus, for instance, when the Colonial Courts of Admiralty Act, 1890 (53\& 54 Viet. c. 27), was enacted, the colonies of New South Wales and Vietoria were excepted because they had not assented.

4 e.g., the British North $\Lambda$ meriea $\Lambda$ ct of 1867 , and amendments of it in $187 x, 7875,1886$, and 1895 ; the eonfirmation of Canalian Aets in 1875 ( $38 \& 39$ Vict. ce. $3^{8} \& 53$ ) ; the eonfirmation of Australasian Acts in 189.1 (56\& 57 Vict. e. 72 ); the provision as to boundaries of eolonies in 1895 ( $5^{8} \& 59$ Viet. $\left.c .34\right)$; [the Commonwealth of Australia Constitution Act $(63 \& 64$ Vict. c. 12)?. The Ministry of Victoria oneo snggested a resort to Parliament to overricle the opponition of the Legislative Council to reform, Parl. P. 1878, C. $2217,111.20,64$. 
Cr. II. The imperial Parliament must also be resorted to where legislation is required to take effect beyond the territory of the possession, as e.g. in matters connected with extradition, bankruptcy, bigamy, offences committed at sea, or wholly or in part outside the territory of the possession, or criminals sent from one colony to another to undergo their sentence. For, except where express power is conferred by the imperial Parliament', a law of the local legislature of a possession operates only within the territorial limits of that possession ${ }^{2}$.

In the statement of constitutional rules it must be recollected that any emergencies may cause them to be broken. Improper action by the colonists or a particular party of them might compel Parliament to legislate in disregard of the ordinary maxims of policy.

(b) Crown. The Crown has the supreme executive power in every British possession. The Governor is appointed by the King; and all administrative and judicial acts are done in the name of the King or of the Governor as his representative. Thus the King is a more prominent link than Parliament between the United Kingdom and the British possession.

But the Crown as the executive power in a possession must be distinguished from the Crown as chief executive power in the United Kingdom or the whole empire.

Whether administrative acts in a possession are done in the name of the Governor or of the King, they are done upon the advice of different ministers from those on whose advice the King acts in the United Kingdom. The acts

1 See as to British India, 32 \& 33 Vict. e. 98 , and other enactments referred to in Ilbert, Gort. of India, pp. 20I-209; and as to other British possessions, the Federal Council of Australasia Act, 1885 (48 \& 49 Vict. c. 60) [now repealed by the Commonwealth of Australia Constitution $\Lambda$ ct] ; the Extradition Act, 1870 ( $33 \& 34$ Vict. c. 52, s. I8); the Fugitire Offenders Act, I88I ( 44 \& 45 Vict. e. 69); the Colonial Prisoners Remoral Act, 1884 ( 47 \& 48 Vict. c. 31 ). Extradition from the Straits Settlements is regulated by Orders in Council (Stat. R. \& O. Rit. vol. vi. p. 436) made under 29 \& 30 Vict. e. II 5 .

2 It is doubtful how far, since the passing of the Territorial Waters Jurisdiction Act, 1878 (4I \& 42 Vict. c. 73 ), a law passed by a colonial legislature operates within the territorial waters of the colony. 
done by the Governor or his ministers, i.e. by the loeal Cr. II. Goverument of the possession, must be distinguished from those done by the imperial or Home Government, that is, by the King acting on the adviee of the ministers of the United Kingdom or by those ministers.

The Crown has also in many possessions a legislative power.

The Home Government, apart from what may be done by IIome the imperial Parliament, acts in different ways, either by order Governof the King in Council, by Letters Patent under the Great Seal, by a doeument passed under the Royal Sign Manual, or' by orders or directions of a Secretary of State.

Acts of a legislative character are usually done by the King in Conneil, that is, by an order made by the King sitting in Council. Such a council is attended, not by all the members of the Privy Couneil, but only by those who are summoned. The present practice is to summon very few, usually from among the cabinet ministers of the day.

The Lord President of the Council has under him a department, manned by permanent civil servants, which aseertains that the draft of every order submitted to the King in Council has been previously approved by one of the cabinet ministers as head of a public department, or by the law officers of the Crown; so that practically the passing of an Order in Council is the last formal act ratifying what has been previously settled by the cabinet ministers of the day.

Legislative acts are also done by Letters Patent under the Great Seal; indeed the establishment of the legislatures of various colonies has been effected in this method. Such Letters Patent are only passed upon a warrant signed by the King, and countersigned by one of the cabinet ministers of the day, who thus becomes responsible for the propriety of the Letters Patent. Similarly an order under the Royal Sign Manual is also countersigued by one of these ministers.

The responsibility for all such acts in whatever form they are done rests constitutionally with those ministers of the Crown who for the time being form what is commonly called 
Сн. II. the 'cabinet,' conduct the government of the United Kingdom, are responsible to Parliament, and practically depend for holding office upon the support of the majority of the House of Commons. But the special responsibility for each particular act depends upon the minister who gives his countersignature or authorizes the submission to the King of an order as above mentioned.

This special responsibility for the government of British possessions belongs to the ancient office of Secretary of State. The duties of this office are distributed between five prineipal Seeretaries of State, who are always privy couneillors and members of the cabinet. One of them (commonly called the Home Secretary) is specially responsible for the Channel Islands and the Isle of Man; another (eommonly called the Seeretary for India) is speeially responsible for India; a third (commonly called the Colonial Seeretary) is responsible for all other British possessions; while a fourth is responsible for foreign affairs, and a fifth for military matters. Each secretary is aided by a department of permanent civil servants, and can do many acts by his own authority without obtaining the signature of the King. It is his duty to countersign documents which are signed by the $\mathrm{King}$, and relate to the British possessions under his charge, and, if an Order in Council is made, he is charged with the execution of the Order ${ }^{\text {. }}$.

Governor. In a British possession the Governor is appointed by the Home Government, and represents it. With the aid of ministers appointed by himself he conducts the administration of the possession and forms the local Government; and administrative acts done in the possession, even though influeneed or ordered by the Home Government, are actually done by the local and not by the Home Government.

Local

legisla-

The Crown in a British possession forms part of a different ture. legislature from that of the United Kingdom. In some

I As to the Privy Council and Secretaries of State, see Anson, Law and Custom of the Constitution, part ii. ch. 4 . 
possessions no doubt laws are enacted by the Governor and Cir. II. the legislative council ${ }^{1}$; but in others, including almost all the self-governing colonies ${ }^{2}$, and some, but not all, of the Canadian Provinces, they are enacted by the King, by and with the advice and authority of the two Houses of the local legislature ${ }^{3}$.

The assent of the Crown to a Bill ${ }^{4}$ for any law is given by the Governor on behalf of the Crom, and if the Bill purports to be enacted by the $\mathrm{King}$ is given in his name. A law, though thus assented to by the Governor, can be disallowed by the King in Council within two years after a copy of it reaches the Home Government, and if so disallowed is void. Also the Governor may be, and in some cases is, required by his instructions from the Home Government to reserve the Bill for the King's pleasure. When a Bill is so reserved it has no force until assented to by the King himself, i. c. by (in effect though not in form) the Home Government.

The old practice of a law having no effect until confirmed by the Crown has ceased except in Gibraltar.

In assenting to laws the Governor, aceording to the character of the possession, or the nature of the legrislation, acts either on his own responsibility or in obedience to instructions from the Home Government, or on the advice of the ministers of the possession.

In the case of the reserved Bills and of the disallowance or the refraining from disallowance of Bills assented to by

1 Especially in colonies not having any representative assemlly. In India they are enacted by the Governor-General in Council. For the form of West Indian taxing Acts in the r8th century, sce Cumpbell v. Ilall, 2o St. Tr. 239, 249, 529.

2 See p. 77 infrid.

${ }^{3} \mathrm{As}$ to the constitution of the legislative and executive authorities, sce Parl. P. r889, No. 70, and 189o, No. 194.

4 'Bill' is the usual term for a proposed law before it recoives the Royal $\Lambda$ ssent. When it is assented to, and therofore passed, it becomes in the United Kinglom and most, if not all, colonios whth representative legislatures an ' $\Lambda$ ct'; in other colonies it beemes an 'Ordinanee' ; in those the Bill may be called a draft Ordinanee, see Colonial Oflice Rules and Regulations, 54 . 
Cr. II. the Governor, the Crown acts on the advice of the home ministers, who are responsible to the imperial Parliament.

The constitutional understanding in the case of selfgoverning colonies is, that disallowance shall only be resorted to for the purpose of protecting imperial interests, or of carrying into effect a policy of general observance throughout the empire. The inconveniences attending its use are so great that it cannot often be used.

But it is not unusual to point out to the Government of a possession objections to proposed legislation, and to suggest either an alteration of the proposed law, or the suspension of its operation until opportunity has been given for the Home Government to reconsider the matter ${ }^{1}$.

The legislature of every colony is subordinate to the imperial Parliament, and, in colonies where the Crown can legislate, to the Crown. And, as above mentioned, the legislation of the colonial legislature has of itself no effect beyond the territory of the colony. Even the King in Council, when legislating in that capacity for a colony, is a local and subordinate legislature, and the legislation has no greater territorial effect than if it were enacted by the ordinary legislature of the colony. In both cases the legislation may be challenged in a court of law as ultra vires.

But the powers of a colonial legislature are plenary and not delegated powers; such a legislature is not a delegate or agent of the imperial Parliament. Therefore the principle of delegatus delegare non potest does not apply, and although the limits of legislation are prescribed, yet within these limits the right of legislation is absolute, and the colonial legislature is supreme, and has the same authority as the imperial Parliament to confer powers on other bodies and persons, as for instance to give a municipal body power to make by-laws ${ }^{2}$.

1 See below, ch. vi. pp. II 7 seq. For list of Acts disallowed or not assented to, see Part. P., 1894, No. 196.

2 This was decided by the Judicial Committee: see cases quoted in Appendix III, and especially, Povell v. Apollo Candle Co., L. R. Io A. C. 282 . 
At common law the Sovereign has the sole power of Cr. II. raising and regulating forees by sea and land ${ }^{1}$. This was declared after the Restoration by the preamble to the Act military I 3 Car. II. Stat. I. c. vi, and by subsequent Acts. forces.

The power as regards naval forees is now exereised through the Lords Commissioners of the Admiralty, who are commissioners to exereise the ancient office of Lord High Admiral. The Royal Navy is raised and governed by them, partly in aceordance with Acts of Parliament, and partly in aceordance with regulations made by the Sovereign.

In I 865 an Aet was passed ${ }^{2}$ under which the legislature of a colony, with the approval of the King in Couneil, may provide, at the expense of the colony, for maintaining vessels of war, and raising seamen for such vessels and volunteers for general service in the Royal Navy, and for appointing officers to train and command these men, and for enforeing order and dis. cipline among them, whether ashore or afloat, and whether within the limits of the colony or elsewhere. These provisions are, however, to be subjeet to such conditions, and the vessels are to be for such purposes, as the King in Council from time to time approves.

Some of the Australasian colonies have availed themselves of this power, but latterly have made an arrangement by which they contribute money towards the equipment and maintenance of eertain vessels in the Royal Navy for service in the waters of the Australian station ${ }^{3}$.

Canada maintains cutters for police and revenue purposes, and Ceylon maintains vessels for police and lighthouse purposes, c.g. for regulating the police of the pearl fisheries, but the vessels so maintained are hardly to bo considered as part of a naval force.

The Indian Government maintains an Indian marine service for the transport of troops, the guarding of convict settlements, the suppression of piracy, and purposes of survey

1 Blackstone, Bk. j. ch. vii. 228 \& 29 Vict. c. 14.

\footnotetext{
5I \& 52 Viet. c. 32.
} 
Сн. II. and lighthouses; and power to govern and maintain the discipline of the ships belonging to this service was given by an imperial Act of ${ }_{1} 884^{1}$. Under that Act the King in Council in case of war may direct that any vessel belonging to the service shall be under the command of the senior officer of the Royal Navy upon the station where the ship may be, and shall for that time be deemed a vessel of the Royal Navy.

As respects land forces, the powers of the Sovereign are exercised through a commander-in-chief, and general and other officers holding commissions from the Sovereign for the purpose.

What are termed the 'regular forces' are raised by the Crown in the United Kingdom, are bound to serve in any part of the world, and are governed by the imperial Army Act, formerly called the Mutiny Act, which is annually passed by Parliament. On the other hand the militia and volunteer forces raised in the United Kingdom are only bound to serve in the kingdom ${ }^{2}$.

The Sovereign has not constitutionally any power to raise a military force without the consent of Parliament; but when a force is raised with that consent can, subject to any cnactment, regulate it in any manner that appears good. The same constitutional rule applies to a colony, but in the case of colonial forces the consent is given by the colonial legislature instead of by the imperial Parliament. The existence of such a force is distinctly recognized by s. 177 of the Army Act ${ }^{3}$, although that section appears to contemplate volunteers or militia rather than a permanent force. That section, however, enables a colonial force to serve outside the colony by providing for the discipline of it when so serving ${ }^{4}$. This provision is made, first by extending the colonial Act to the

${ }^{1} 47 \& 48$ Vict. c. 38 . See Ilbert, op. cit., p. 208.

2 Their members may volunteer for service elsewhere. See as to the Militia, $45 \& 46$ Vict. c. 49 , s. I2, as amended by 6 I \& 62 Vict. c. 9, s. 2.

s 44 \& 45 Vict. c. 58 .

- It will be remembered that several colonies sent contingents to serve in South Africa in 1899 and subsequent years. 
military force wherever it may be, and secondly, by extending Сн. II. to the foree when serving with the regular forces the Army Act, with certain modifications.

In most of the colonies the forces raised are militia or volunteers, serving only within the colony, but in others, e.g. New South Wales, colonial Acts have been passed authorizing the raising of forees of a rather different character.

A New South Wales Act ${ }^{2}$ authorizes the Governor on behalf of the Crown to engage such number of men as the New South Wales Parliament from time to time provides for. Each man so engaged is to bind himself to serve for a number of years, and is to be subject to the imperial Army Act in force for the time being, and to the King's regulations for governing the army. The command-in-chief in the Sovereign's name is vested in the Governor, who is empowered to appoint the officers and issue commissions under his hand and the seal of the colony, and to convene, and to delegate the power of convening, a court-martial ${ }^{2}$.

'[In Canada the militia consists, according to the Militia Act of $1886^{4}$, of all the male inhabitants of the age of eighteen years and upwards, and under sixty-not exempted or disqualified by law, and being British subjects by birth or naturalization; but His Majesty may require all the male inhabitants of Canada, capable of bearing arms, to serve in case of a levié en masse. The militia-or any part thereofmay be ealled out for active service either within or without Canada at any time when it appears advisable so to do by reason of war, invasion, or insurrection, or danger of any of them. In time of peace, 45,000 militia may be trained

1 No. Ig of 1871 .

2 [As to the control of the Crown in military and naval matters in tho colonies, see Todd, Parliamentary Goremment in the Colonies, and ed., ch. xii, and, in particular, the procedings fully deseribed in that chilpter as to the dismissal of Mr. Molteno by Sir Bartle Frere in 1877.$]$

3 [I have added here some information supplied to me by the Colonial Office as to the militia and similar forees in Canada, tho Cane, and the Australasian colonies. C. I. I.]

449 Vict. c. 11 ; Revised Statutes of Canada, ch. 4 I. 
Сн. II. annually for a period not exceeding sixteen days or less than eight days in each year. The several corps are subject to such inspections from time to time as His Majesty may direct.

In the Cape Colony the Burgher Force and Levies Act ${ }^{1}$ provides for all males between the ages of eighteen and fifty, with certain exemptions, being placed on a burgher list, and for the Governor assembling the men on this list or such of them as may to him appear expedient for inspection, or for inspection and rifle practice, when and where, within their respective divisions, he may direct. The Governor may, whenever it is necessary for the defence of the colony or any part thereof, call out the whole or part of the burgher force or levies for service within the colony or beyond the borders thereof.

In South Australia the Defences Act of $1895^{2}$ makes all British male inhabitants between the ages of eighteen and forty-five liable, with certain exemptions, to military service in any part of Australia or Tasmania, but not elsewhere, in case of actual invasion or the imminent prospect thereof, and to continue to serve until the Governor proclaims that the invasion or prospect thereof has ceased. The Governor is empowered to appoint officers to keep up a roll of persons liable to serve.

The defence force in Queensland ${ }^{3}$ consists of all male inhabitants, with certain exemptions, between the ages of eighteen and sixty, who are British subjects, and a roll of these inhabitants is required to be kept up. They can be called out to complete establishments which cannot be filled by volunteering, in case of war or invasion or imminent danger thereof, for service in any part of the Australian colonies.

In Tasmania the Defence Act ${ }^{4}$ constitutes a defence force consisting of all male inhabitants, with certain exemptions, between the ages of eighteen and fifty-five, being British subjects, and provides for a roll of these inhabitants being kept up. They can be called out for service in the colony at

1 No. 7 of 1878 .

2 Act No. 643 .

3 Defence Act, 1884,48 Vict. No. 27. 49 Vict. No. I6 (1885). 
any time, to complete establishments which cannot be filled Crr. Ir. by volunteering, and are liable to serve in peace for three years, during which they may be trained for a period of not more than sixteen or less than five days in a year.

In New Zealand, according to the Defence Act ${ }^{1}$, the militia consists of all male inhabitants, with certain exemptions, between the ages of seventeen and fifty-five, and a roll of such inhabitants is required to be kept up. The whole of the militia or any part thereof is to be trained as a military foree for service in the colony, but no man is to be compelled to train more than seven days in the year.

The compulsory powers contained in these Acts are not now actually enforced, and similar powers are not given by the military Aets of Natal, Western Australia, Vietoria, and New South Wales.]

Any colonial force of the kind described above would be a force such as is referred to in 5.177 of the imperial Army Act, and even though the men in it have engaged to serve in any part of the world, would not be part of the regular forees, but a distinet force. Consequently an officer of the regular forees would not, as such, have any command over the officers and men of the colonial foree, nor would an officer or man of the colonial foree have, as such, any command over an officer or soldier of the regular forces.

And if the King were to grant commissions giving eommands to officers of the regular forces over officers and men of a colonial foree, this might be considered to be an increase of the regular forees made without the consent of Parliament.

Portions of the regular forces of the United Kingdom were formerly maintained in several of the colonies, but since 1870 the troops have been gradually withdrawn, except so far as garrisons are required for certain naval stations, such as Halifax, or Simon's Bay in the Cape ${ }^{2}$. The fortifications

1 No. 17 of 1886 .

${ }^{2}$ [The present situation in South $\Lambda$ friea had not arisen when this chapter was written.] 
Сн. II. which had been erected by the Home Government or obtained by conquest, have also of late years been transferred to the colonies in which they are situate, a transfer authorized by an imperial Act ${ }^{1}$.

The land defence of every colony was thus left to the colonial Government, but undoubtedly if war should arise the Home Government would, to the extent of its ability, defend the colony by land as well as by sea, unless indeed the quarrel were one entered into by the colony against the will of the Home Government.

The Home Government has pressed several colonies to erect fortifications for their own defence, and in some instances, where the fortifications were of general benefit to the empire for the purpose of naval defence, has made a contribution towards the expense of them.

Subjects for exercise of imperial authority.

The various subjects in respect of which the authority of Parliament and the Crown can be exercised in a British possession may be summarized under the following heads :-

(a) The relations of the British possession with other communities, whether part of the British dominions or of foreign countries, including the defence of the British possession against foreign foes.

(b) The external affairs of the British possession, such for instance as trade, shipping, or matters of law and policy affecting the whole empire, and including the rights and duties of the inhabitants of the possession when outside that possession ${ }^{2}$.

(c) The judicial arrangements of the possession.

(d) The supreme executive government of the possession.

(e) The internal government of the possession, i.e. its domestic institutions, civil, moral, and religious, and the administration of the government, including finance.

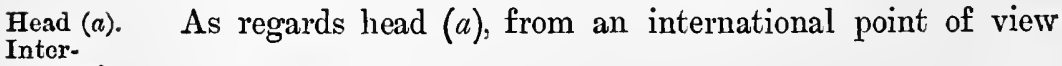
national relations.

${ }^{1} 40 \& 4$ I Vict. c. 23 .

2 [I have not ventured to alter the arrangement, but heads $(a)$ and $(b)$ seem to overlap each other. C. P. I.] 
the British possessions are not independent political societies, Crr.Ir. but are part of the British Empire, though in the case of the self-governing colonies and British India, their position has gradually assumed that of members of a federation rather than that of an integral part of a single dominion.

Imperial federation is in a strict sense a contradiction in terms. The imperial Parliament and the Home Government, i. e. the King as advised by the ministers of the United Kingdom, form the supreme power of the empire. In that supreme power the people and Government of a British possession have no direct share. They are not directly represented in Parliament, and therefore have no direct influence in the selection of the ministers, or the adoption of any particular policy.

British possessions are therefore subordinate members or dependencies of an empire, and not members of a federation; because each member of a federation has a share in the central supreme power of the federation. But according to constitutional practice the self-governing colonies, and to some extent British India, are treated as members of a federation rather than as subordinate dependeneies.

British possessions are all bound by treaty made by the Home Government with foreign countries; and the local Governments of those possessions have no direct communication with any foreign Government. Any such communication must pass through diplomatic representatives appointed by and aeting under the direction of the Home Government.

But it is now the constitutional practice to exclude every self-governing colony from any treaty which affects the internal law of the colony unless the colonial Goverument assents to its inclusion; and a right is reserved to denounce the treaty for each such colony separately 1 . Also in some international conferences the self-governing colonies and

' See for example the Berne Copyright Convention, 1885, and the Conventions for the Postal Union and the Postal Convention with Franco of 1890 , as to which see the Mail Ships Act, I89r (54\& 55 Vict. e. 31 ). 
Сн. II. British India have been represented by separate delegates, and representatives of the colonies have been associated with the appointees of the Home Government in negotiations with a foreign state or in a joint commission ${ }^{1}$.

Every treaty, however, which affects a possession, binds the local Government of the possession, whether it has or has not assented. But a treaty is not law, and if a change of law is necessary to give effect to the treaty, legislation is required. That legislation may no doubt be effected by an Act of the imperial Parliament, if the local Parliament refuses to pass it, and would then bind all the courts and persons in the possession. But the administrative measures required for enforcing the treaty might give rise to difficulties. Practically, the Government of the possession cannot be compelled to take such measures against their will, and if they refuse to take them, the Home Government may be embarrassed by a demand from the foreign state for the enforcement of the treaty 2 .

In I89I a Bill for enforcing in Nerwfoundland the Treaty of Utrecht with France passed the House of Lords, and was only withdrawn in the House of Commons because the Newfoundland Legislature passed a similar measure. In that case the Act could have been enforced on the sparsely populated 'French shore' of Newfoundland by British menof-war.

Instances have occurred of a foreign state complaining to the Home Government of the legislation of a British possession, because it is contrary to a treaty, or is inconsistent with peaceful relations with that state ${ }^{3}$.

1 As, for example, in the Postal and Telegraphic Conferences, and the Bi-metallic Conference at Brussels, and in the Joint Commission and Conference with the United States.

${ }^{2}$ A difficulty of this kind arose between the United States and Italy when some Italian subjects were killed in Louisiana, and redress could not be obtained in the Louisiana courts. See also Lewis, Gov. Dep., p. 296. On the question whether a treaty can alter the rights of private persons, see Walker v. Baird, L. R. [r892] A. C. 49I.

3 For instance, China, on account of New South Wales and Victorian Acts excluding Chinamen; and Japan, on account of British Columbian legislation excluding Japanese. As to the latter case, see below, p. IIg. 
Any complaint may usually be met by the power of the Cr. II. King to disallow the Act complained of, but the legislation may drive the Home Government to denounce the treaty ${ }^{1}$.

And undoubtedly the Home Government may find itself involved in international difficulties, and possibly in war, owing to acts of the Government of a British possession for which the Home Government are interuationally responsible, although practically unable to eontrol or remedy them ${ }^{2}$.

British possessions, though bound by the treaties of the Home Government, have the correlative right to the protection of that Government, both in a diplomatic and in a military sense. They are proteeted by the British navy and army against foreign and often against internal foes; their ships carry the British flag, and obtain all the protection and advantages which the British flag enjoys throughout the world; and the individual inhabitants obtain in all foreign countries the protection and assistance of British diplomatists and consuls. For this protection and these advantages the British possessions until recently made no peeuniary contribution, though latterly the colonies in Australia and the Cape have made a contribution towards naval expenses; and British India and New South Wales, and still more recently others of the self-governing colonies, have sent military forces to aid the imperial forces in Malta and Africa. This aid from the self-governing colonies has been voluntarily given with the patriotic object of supporting the British Empire, and proving their fellowship in it. It does not alter the constitutional point of view that there is no legal obligation to render such aid. And it is open to any colony which disapproves of or is not interested in the object of a war to refuse the aid. Indeed writers in at least one of the colonies have challenged the expediency of giving such aid, on the

1 For instance, the Canadian fiscal legislation in 1898 led the Home Government to denounce the German Commercial Treaty.

${ }^{2}$ The history of British India, events in South Africa, and the seal question in the Behring Sea, aro illustrations. 
Cr. II. ground that the colony has no voice in the question of peace or war.

Inter- In the relations of one British possession to another the colonial relations.

Crown is the connexion between them. All formal communications pass through the Home Government, and that Government is the arbiter in all serious disputes, whether arising from frontier difficulties, as e.g. between New South Wales and Victoria, or from the treatment by one possession of the inhabitants or ships of another, as e. g. in the case of British Indians in Natal, or of refusal of entry to a colonial ship on the grounds of there being infectious disease on board.

Head (b). As regards head (b), i. e. the external affairs of a British. External affairs. possession, it is obvious that all legislative or administrative action respecting the relations under this head must be that of the imperial Parliament or the Home Government.

Imperial Acts give effect to treaties, as for instance those relating to seal hunting in the Behring Sea, or international copyright; provide (by the Foreign Enlistment Act) for the maintenance of neutrality in wars between foreign countries; and regulate the prosecution of crimes committed by foreigners on board foreign ships within the territorial waters of a British possession. The administration of these Acts is largely left to the Home Government, or to the colonial Governor acting as the representative of that Government.

The extradition of criminals, whether to a foreign state under treaty, or to another part of the British dominions, is also provided for by imperial Acts, though these Acts enable effect to be given to the legislation of a possession on the subject ${ }^{1}$.

The necessity for imperial legislation to provide for extradition between different possessions arises from the inability of a legislature of a possession to legislate for matters beyond

1 As to foreign states, 33 \& 34 Vict. c. 52 ; 36 \& 37 Vict. c. $60 ; 58$ \& 59 Vict. c. 33. As to British dominions, $44 \& 45$ Vict. c. 69. 
the boundary of the possession?. Legislation on extradition

by such a legislature was considered to be ultra vires as being extra-territorial, and for this reason the Federal Council of Australasia Act, $1885^{2}$, gave express powers to the Federal Council to legislate on the subject.

The same inability renders it necessary for the imperial Parliament to legislate, or to give express power to a colonial legislature to legislate, for the punishment in a possession of crimes committed outside (e.g. on the high seas), or for the removal out of the possession of convicted prisoners to undergo their punishment elsewhere ${ }^{3}$.

It is only an imperial Act that can give effect outside a possession to an enactment of that possession vesting a bankrupt's whole property in a trustee for his creditors, or can confer on an author of a book, by the mere fact of his publishing the book in the possession, copyright in every part of the British dominions.

In England the regulation of the general commercial policy of a possession was in former days universally recognized as a proper attribute of the Home Government ${ }^{4}$; but, as regards the self-governing colonies at least, not only has this doctrine been abandoned ${ }^{5}$, but the Home Government has acquiesced in colonies imposing protective duties on the importation of manufactures of the United Kingdom. A survival of the older system of regulation is still to be found in the prohibition of the importation into British possessions of unlaw-

1 [See In re Gleich: Olivier, Bell \& Fitzgerald's Reports, New Zealand [Supreme Court, p. 39], and ef. p. 70 infr:t.]

${ }^{2} 48 \& 49$ Vict. c. 60 [repealed and superseded by $63 \& 64$ Vict. c. 12].

$3 \Lambda$ to offences at sea, $12 \& 13$ Vict. c. $96 ; 23 \& 24$ Viet. e. $122 ; 37 \& 38$ Vict. c. 27. $\Lambda$ s to the removal of prisoners, $32 \& 33$ Vict. c. 1o; $44 \& 45$ Vict. e. $69 ; 47 \& 48$ Vict. e. 31 . Tho jurisdietion of a colonial court to try and punish for bigamy an inhabitant of the colony who married his second wife outside the colony, depends on the imperial $\Lambda$ ct, 9 Geo. IV. c. $3^{I}$, though that $\Lambda$ et has been repealed as respects the United Kingdom. A colonial law cannot give the jurisdietion, as it is oxtra-territorial. [Sce Mracleod v. Attorney-General for New South Wales, L. R. [1891] A. C. 455.]

1 Lewis, Gov. Dep., pp. 82, I39, I58, 240, 348; Merivale, op. cit., pp. 192, 622.

- See 29 \& 30 Vict. c. 74 ; $5^{8}$ \& 59 Viet. e. 3 . 
Crr. II. fully printed copies of copyright books. The regulation of the coasting trade was expressly abandoned in 1869 by an imperial Act which enabled the legislatures of British possessions to legislate on the subject ${ }^{1}$.

The slave trade is prohibited by an imperial Act throughout the British Empire as a part of general imperial policy ${ }^{2}$. But the maintenance of the general principles of English law in British possessions is usually effected rather by disallowance of legislation contrary to those principles ${ }^{3}$, than by positive legislation of the imperial Parliament.

Merchant shipping is regulated mainly by imperial Acts. But by these Acts the legislatures of British possessions are expressly authorized to legislate for their own coasting trade, and the King in Council is empowered to allow provision to be made for certain local matters by local legislation in substitution for the provisions of the imperial Act. The reasons for this lind of regulation are, partly the need for extraterritorial legislation, partly the fact that foreign countries are concerned, and partly the importance of maintaining a uniform law for all vessels which enjoy the protection of the British flag.

Coinage should also be mentioned in this connection, because a coin coined in a British possession cannot ipso facto be a legal tender in any other part of the British dominions, unless so made by imperial authority or by special legislation in each such part. The regulation of the coinage is one of the ancient prerogatives of the Crown, and has remained so in British possessions; and is there exercised either by an Order in Council of a legislative character, or by a proclamation of the King in Council. This prerogative has, in nearly all British possessions except India and Canada, been converted

${ }^{1} 32 \& 33$ Vict. c. II, repealed by and re-enacted in 57 \& $5^{8}$ Vict. c. 60 , s. 736 .

${ }^{2} 5$ Geo. IV. c. Ir 3 .

3 e. g. Acts authorizing marriage with a deceased wife's sister were formerly repeatedly disallowed, but have in recent years been allowed. 
into statutory power by the Coinage Act, I870, and Orders in Cur. II. Council made under it 1 .

In many British possessions the coinage has been regulated by local legislation, and in a few by imperial Acts.

In British India, the East India Company, under power given by early charters from the Crown established mints, which have continued ever since, and are regulated by Indian legislation 2. Coins minted there were, by Order in Council, made legal tender in Ceylon and other eastern British possessions ${ }^{3}$. But the recent introduction of a gold standard, with the sovereign as legal tender, has led to proposals for the establishment of a branch of the royal mint for the coinage of sovereigns in India.

Except in India the only coins lawfully issued in the British Empire are coined by or under the direction of the Royal Mint in England, of which the Chancellor of the Exchequer is master, and a civil servant is deputy master. Branches of that mint, under deputy masters appointed by the Home Government, have been established in three of the Australasian colonies ${ }^{4}$, and the expenses are defrayed and the receipts received by the colonial Governments. But in law, the deputy master in the colony and his officers are officers of the Royal Mint in England, and coins which are coined in a branch mint are treated as coined by the Royal Mint, and have currency accordingly in other parts of the empire, not only where the current coins are of the same denomination as

${ }^{1} 33 \& 34$ Vict. c. 10 . The Orders in Council extending the Act to British possessions are published in Stat. $R$. \& O. Rer., vol. i. pp. 627-30; Stat.R.\& 0., 1896, p. 13; 1898, pp. 13, 22.

2 Ilbert, op. cit., pp. 20, 22, 123, 222. The Governor-General in Council alone, and not the local Indian legislatures, can regulate the coinage.

3 See Stut. R. \& O., 1896, p. 840. British dollars have been coined in India for the sole purpose of circulation in Hong-Kong and Labuan, Stat. R. \& $0 ., 1895, \mathrm{pP} \cdot 708,764,769$. [The silver rupee of Britisle India has been mado the standard coin of the East African Protectorate, Stat. R. \& $0 ., 1898, \mathrm{p} .376$.

- At Sydney, Melbourno, and Perth. [Seo Stat. R. \& O. Rev, vol. viii. p.. 627-4I ; Stat. R. \& 0., 1894, p. 33; 1896, p. I3; I900, p. 21.] 
Cu. II. those of the United Kingdom, but in parts like Canada, where dollars are in use.

Hitherto, gold coins alone have been coined in the colonial branch mints. If silver coins were coined there, the imperial control would be clearly necessary in order to prevent an excessive coinage, because the silver coins are only token coins; and a difficulty might arise from one colony taking the profit when the coins are largely used in another colony, and the profits of such coinage are large.

For Canada and other British possessions which use coins of different denominations from the British pound and shilling, dollars and other coins are coined at the Royal Mint in England, and the possession pays the expenses or receives the profit?

As respects private law, each British possession is a separate country, just as Scotland or Ireland is a separate country from England. Thus there may be a conflict of laws between a British possession and England, or between two British possessions, just as there may be between Scotland and England. The supremacy of the imperial Parliament may limit this conflict, as above pointed out, in cases of general imperial policy, or cases like bankruptey; but the proposals in this direction, made at the colonial conference in 1887 , did not lead to much, the net result being an Act for resealing in England probates of wills obtained in a possession ${ }^{2}$.

More effect in this direction is obtained from the tendency of British possessions to make their private law agree with English law, particularly in commercial matters, such as those relating to joint stock companies ${ }^{3}$ or merchandise marks ${ }^{4}$; and

1 The history and condition of colonial currency are exhaustively treated in the book entitled Colonial Currency, by Robert Chalmers.

${ }^{2} 55 \& 56$ Vict. c. 6.

3 Companies incorporated by'charter, e. g. banking companies, have asserted that their charter exempts them from colonial law; but recent practice in both charters and imperial Acts of a local character conferring powers on a company is to declare expressly that the company shall not be so exempt.

- In 1887 the imperial Merchandise Marks Act of that year was sent to each British possession with an invitation to enact a similar law. 
from the supervision over loeal legislation which is exereised by Crr. II. the Home Government to a greater or less extent, aceording to the character of the possession.

The inhabitant of a British possession when outside the British dominions remains, equally with an Englishman, within the allegiance of the King, and is therefore subject in many respeets to British law; but the law to which he is so subject is (apart from questions, such as succession, which depend on domicile) English and not colonial law. If he is on board a ship of his own possession he earries with him, by virtue of the Merehant Shipping Aet ', the law of that possession in all matters to which that Act does not apply; but if he is on board any other ship, or dwells in (say) China or Turkey, he carries with him, and is subjeet to, English law.

As regards head $(c)$, judieial matters, all writs run and pro- Head (c). ceedings are earried on in the name of the Crown 2 . In most Judicial British possessions the courts were established by charter ments. under the Great Seal of the United Kingdom. In some cases their establishment was authorized by imperial Aets, but sineo I $865^{3}$ the intervention of the Home Government is not so mueh required for the establishment of courts.

Except in the self-governing eolonies, the judges are appointed by the Home Government; and in every British possession they ean be removed by the Governor and council of the possession for absence without reasonable eause, neglect,

${ }^{1} 57$ and $5^{8}$ Vict. c. 60 , s. 265 .

2 Professor Dicey (Law Const., p. 10) calls tho doctrine that all jurisdiction of the courts is derived from the Crown an unreality and a fiction. But the doctrine is true historically, though the development of law in England may conceal the truth. Even in Eugland the King may still creato a prize court, and until i89 the Crowu was perhaps the sole authority for creating such a court. See 54 \& 55 Vict. c. $53,8.4 ; 57$ \& $5^{8}$ Vict. c. 39. The truth of tho doctrine clearly appears in tho judicial history of British possessions, and it still has sulstantial reality in tho less developed communitics outside tho United Kingdom.

${ }^{3}$ The date of the passing of the Colonial Laws Validity Aet, I865 (28 \& 29 Vict. c. 63 ), printed in $A$ pl. V infra. Seo also 50 \& 5 I Vict. c. 54. 
Сн. II. or misbehaviour, subject to an appeal to the $\mathrm{King}$ in Council ${ }^{1}$.

An appeal lies to the King in Council from the decision of every court in a British possession ${ }^{2}$. In most cases this appeal is of right, in others leave to appeal has to be obtained from the King in Council. Thus a person convicted of murder or of any other offence can and occasionally does petition the King for leave to appeal, although in England there is no such appeal by a person convicted. But partly by rule, partly by practice, and partly by colonial legislation, the appeals are so limited as to prevent any great delay or inconvenience in the administration of justice. Thus a person convicted by a jury only obtains leave to appeal if there is substantial ground for believing that there has been a grave miscarriage of justice ${ }^{3}$. And a civil suitor is refused leave to appeal to the King until he has exhausted his rights of appeal in the colony.

The petition for leave to appeal, and the appeal, are made to the King, and the order upon the petition or appeal is made by the King in Council. But every petition or appeal is referred to a committee of the Privy Council called the Judicial Committee, and is heard by that committee, and the order of the King in Council is always made in accordance with the advice of the committee, the purport of which is stated in a single judgement read in open court.

Constitutional questions of great importance to a colony have been referred by the Sovereign to the Judicial Committee, such as the powers of the legislative council of Queensland in respect of money Bills, and the validity of Protestant marriages

1 By Burke's Act, 22 Geo. III. c. 75: see Willis v. Gipps, 5 Moo. 379 ; Montague v. Lieut.-Governor of Van Diemen's Land, 6 Moo. 489. See also memorandum as to removal of colonial judges in 6 Moo. N.S., Appendix IX, set out in Tarring, Lavo relating to the Colonies, p. 162 .

${ }^{2}$ See, however, as to appeals from the Federal Court of Australia, s. 74 of the Commonwealth Constitution in $63 \& 64$ Vict. c. I2, and p. 89 infra.

3 [See Ex parte Deeming, L. R. [1892] A. C. 422 ; Tops v. the Queen, L. R. [1894] A. C. 650.] 
in Malta, and upon their report have been decided by the Cr. II. Sovereign in Council 1 .

The Judicial Committee consists of the most eminent judges in the United Kingdom; and to them have been added, since 1895 , certain eminent colonial judges 2 .

The jurisdiction of a court in a British possession is limited to the possession and its territorial waters, exeept so far as a wider jurisdiction is conferred by an imperial Act ${ }^{3}$.

In criminal matters this jurisdiction has been conferred in most cases where similar jurisdiction is exercised by English courts. In civil matters, the most important branch of extraterritorial jurisdiction, that of the Admiralty Court, was, until 1890 , mainly exercised by Vice-Admiralty Courts established by an instrument under the seal of the office of admiralty, issued in pursuance of authority given to the Commissioners of the Admiralty in England by a commission under the Great Seal of the United Kingdom. In practice, a judge of the Superior Court of the possession was always made judge of the Vice-Admiralty Court; but he held that office by virtue of an appointment from the British Admiralty, and not by virtue of his position as judge of the possession. His jurisdiction therefore was vested in him personally, and not in the colonial court; and if he was incapacitated, could not be exercised by his brother judges.

In I890, the Superior Court itself was in most of the British possessions made an Admiralty Court, subjeet to rules to be made by Order in Council; but the power of the King to set up Vice-Admiralty Courts is reserved ${ }^{4}$.

1 See Purl. P., 1894, No. 214; 1896, C. 7982.

2 Under the Act 58 \& 59 Viet. c. 44 any one who is or has been a juclge of a Superior Court in Canada, any Australasian colony, the Cape or Natal, or of any other Superiol Court of tho British dominions named by tho King in Council, should, if a Privy Couneillor, be a momber of the Judieial Crmmittce. As the King can appoint any person to bo a Privy Councillor, this in effect enables him to ap point any of those judges to be members of the Judicial Committee.

${ }^{3}$ [See, howev'], 1. 12, uote 2, supra.]

4 The imperial Act, 53 \& 54 Viet. c. 27 , empowered tho legislaturo of 
Cr. II. The King can also appoint a vice-admiral in any British possession, and if none is so appointed, the Governor of the possession is vice-admiral ${ }^{1}$. He has practically no powers, except in connection with prize courts.

Prize courts are international courts, and exist only in time of war; but in 1894 , to meet the exigencies created by telegraphs and other conditions of modern warfare, power was given to the Crown to issue for prize courts in British possessions dormant commissions, which become effective upon a proclamation by the vice-admiral that war has broken out ${ }^{2}$. The commission may be given to the colonial Court of Admiralty; but the court when acting as a prize court is an imperial court, and not a court of the possession. Appeals from colonial Courts of Admiralty and prize courts lie, as do those from Vice-Admiralty Courts, to the King in Council ${ }^{3}$.

Head $(d)$. Governor.

As regards head $(d)$, the supreme executive goverument of a British possession is vested in the Governor, aided (with two or three exceptions) by local ministers; and many, if not all, administrative acts are done in the name of the Governor or his ministers, and not of the King.

The powers of the Governor, and his relations to his ministers and to the Home Government, vary so much that little is common to all British possessions, except the existence of the Governor, and his responsibility to the courts in England and the possession, a responsibility which extends to any other officers appointed by the Home Government 4 .

a possession to declare any court of unlimited jurisdiction to be a colonial Court of Admiralty. Any law affecting a colonial Court of Admiralty, unless previously approved by the Home Government, must be reserved, or contain a suspending clause. New South Wales, Victoria, St. Helena, British Honduras, and the Channel Islands, were excepted from the Act until it was applied by Order in Council. 'The two first colonies did not assent to the application of the Act.

${ }^{1} 55 \& 56$ Vict. c. 27 , s. 10.

2 The Supreme Court of the United States is, under the Constitution, a dormant prize court.

${ }^{3} 53 \& 54$ Vict. c. 27 , s. $6 ; 57 \& 58$ Vict. c. 39.

4 The powers and position of the Governor are dealt with more fully in chapter vi. The title of Governor given to the clief executive officer 
The Governor of a British possession and any other officers Crr. II. appointed by the Home Government to hold office in the possession are amenable to the High Court in England in respect. of their acts done in the possession. They are liable to eivil actions brought in that court by individuals, whether inhabitants of the possession or of the United Kingdom, for the recovery of damages for any injury 'eaused by their action, and cannot escape liability because their action was an Act of State or ordered by the Home Government ${ }^{1}$.

They are further liable in a eriminal court in England to prosecution for offences eommitted in the possession ${ }^{2}$. Both the civil and criminal proceedings are in the ordinary courts, and not before a special tribunal for government officials.

Judges of the Supreme Court of any possession can also be removed by Order of the King in Couneil ${ }^{3}$, and this power of removal is in addition to the power of removal by the Governor and his council 4 , and to any power of removal provided by the law of the possession. The law of the possession usually follows the law of England, i. e. that a judge ean

of each state in the United States appears to be a survival from the time when the state was a colony of Eugland with the Governor appointed by the Crown.

1 An action was brought against the Governor of Gibraltar for assault and false imprisonment, Glyn v. Houstoren, 2 MI. \& G. 337, and for an illegal court-martial, Conner v. Sabine (cited in Fobrigas v. Mostyn); against the Governor of Minorea for assault and false imprisomment, Fabrigas v. Mostyn, 20 St. Tr. 81, see pp. 218, 228, 232 ; against tl.o Governor of Jamaica, Phillips v. Eyre, L. R. 4 Q. B. 225, 6 Q. B. I. See also Co. Litt. 39I (a) IIargraves' note; Tarring, Law Col., p.5 I ; Smith's Leuding Cases, 7 th ed., vol. i. pp. 670,679 .

"Under II Will. III. c. I2, as to governors, which was extenderl to all persons in the service of the Crown hy 42 Geo. III. c. 85 , General Picton was tried for illegally ordering torture while Governor of 'Trinidad, but judgement was never given, 30 St. Tr. 225, 955. Seo also Li. v. Eyre, L. R. 3 Q. B. 487. The Act does not apply to felonies; but under the Act relating to the trial of murders committed abroat Governor Wall was ernvicted in England and hanged for nurder committed by him whon Governor at Gorec in West Africa by excessive Ilogrging of a sollior: 28 St. Tr. 5 I.

s See memorindum by Privy Conncil, 6 Moo. P. C., N. S., Appendix IX; Tarring, Lace Col., p. 162.

- Under liurke's Act, 22 Geo. III. ‘. 75. 
Сн. II be removed by the Crown on the address of the two Houses of the legislature, but not otherwise. Head $(e)$. As respects head $(e)$, the internal government of a British
Internal govern- possession is left almost entirely to the local government ment. except so far as it is affected by its relation to imperial policy or external affairs. Except in those cases the imperial Parliament never interferes; but the position of the possession as member of the empire, and the influence of the Home Government, whether by control over the legislation of the possession, or by advice or direct administrative interference, have more or less influence on the internal government. The extent of that influence, and in particular the financial control, vary so much, that they must be dealt with among the differences between, rather than among matters common to, all British possessions. 


\section{CHAP'TER III}

\section{BRITISH POSSESSIONS OTHER THAN COLONIES}

THe general relations between the Home Government and Cir. III. all British possessions have been stated in the last chapter. It now falls to state the differenees between various classes $\begin{gathered}\text { Posses- } \\ \text { sions }\end{gathered}$ of British possessions, and for that purpose to state in more which are or less detail their constitution and position in relation to the colonies. United Kingdom.

The British possessions which are not colonies, namely the Channel Islands, Isle of Man, and British India, will be first dealt with.

The Channel Islands and the Isle of Man, which, together with the United Kingdom, are frequently called the British Islands ${ }^{1}$, are the oldest of the British possessions.

The Channel Islands indeed claim to have conquered Channel England, and are the sole fragments of the dukedom of Normandy which still continue attached to the British Crown. For this reason, in these islands alone of all British possessions, does any doubt arise as to whether an Act of the imperial Parliament is of its own foree binding law. In practice, when an Act is intended to apply to them, a section is inserted authorizing the King in Council to issue an Order for the application of the Act to these islands, and requiring the registration of that Order in the islands and the Order in Council is made by the King and registered by the States accordingly.

'This description is recognized and authorized by the Interpretation Act, 1889 (52 \& 53 Vict. c. 63 ), s. 18 (3). 
Cн. Il I. Guernsey and Jersey have their own legislatures and execntives. The legislature consists in each case of a quasi-representative body called the States, with certain legislative and administrative powers. Sark and Alderney are in the bailiwick of Guernsey. The body called the States is composed partly of nominees of the Crown and partly of officers elected, some for life, others for a short term of years, by the richer ratepayers.

The States of Jerscy, with the consent of the Governor, can pass a law without the King's consent to last for three years only, but except in that case a law passed by the States either of Guernsey or Jersey requires the assent of the King in Council.

Alderney has a separate court and States of its own; but there is an appeal to the Royal Court of Guernsey, and the States of Guernsey legislate for Alderney.

The King in Council can also legislate for the islands, but whether that power to legislate can be exercised without the consent of the States is a moot question, which has been twice argued before the Judicial Committee of the Privy Council, but not decided .

The Royal Courts in each island, consisting of the Bailiff nominated by the Crown and twelve Jurats elected for life by the richer ratepayers, have judicial, and in Guernsey, some minor legislative functions.

The Governors of Guernsey and Jersey are appointed by the King on the advice of the Home Secretary.

Each island has its own special laws, resting largely on the old Coutume de Normandie, and its own customs duties, or rather absence of duties. Until some time after the beginning of the nineteenth century, the islands formed the base

1 See the cases of Re States of Jersey, 9 Moo. P. C. 185, and Jersey Prison Board, 8 St. Tr. N. S. 286, where some of the information collected for the argument is given. App. C in $8 \mathrm{St}$. Tr. 1127 contains a reprint of the report of the Royal Commission of 1846 , which gives a full account of the law and institutions of the Channel Islands. See also Anson, L. \& C., pt. 2, ch. v, and Falle v. Godfray, L. R. I4 A. C. 7 o. 
from which a large amount of smuggling was carried on Crr. III. into the United Kingdom.

The islands make no contribution towards the British navy or army, the maintenance of the Crown, the diplomatie service, or the National Debt, and indeed liave raised difficulties about placing their militia in an effieient state.

The Isle of Man is in a different position. The lordship Isle of of the island was granted by the English Crown to a noble, Man. and was eventually repurehased by it from his descendants in 17651 .

The island has a legislature of its own-the Court of Tynwald-consisting of two branches, the Council and the House of Keys.

The Council consists of the Governor, the Bishop (who is the sole representative of the old barons), the Attorney-General, the Clerk of the Rolls, the two Deemsters (i.e. judges), the Archdeacon, the Receiver-General, and the Vicar-General. Of these all are nominated by the Crown, exeept the VicarGeneral, who is appointed by the Bishop.

The House of Keys consists of twenty-four members, who were formerly co-opted with the approval of the Governor, but are now elected by popular election.

When a law has been passed by each branch separately, it is signed at a meeting of the two branches held under the presideney of the Governor, and must be signed by a majority of the House of Keys. It is then sent to the Home Secretary for the Royal Assent, which is given by the King in Council. It does not, however, become law until promulgated at the Tynwald Court, held usually on July 5 (Tynwald Day) with aneient ceremonies on a particular hill.

The Governor, as representing the Sovereign in his capacity of Lord of Man, was until recently the sole judge in the isle,

1 Under 5 Gen. III. c. 26. See also 45 Geo. III. c. 123 aud Parl. P., 1805, vol. ix. 3. The Land of Home liule, by Sir S. Walpole, K.C.B., sometimo Governor of the Isle of Man, gives an interesting account of the history nd present condition of the island. 
Cr. III. and the only person capable of issuing a warrant of arrest. The ordinary judges are called Deemsters, and, when there was an appeal, sat with the Governor to hear the appeal. But they were assessors only, not judges, so that if the Governor differed from the two Deemsters his judgement prevailed.

The Governor also personally administers the government of the island without the aid of any ministers, but is under the control of the Home Secretary with respect to ordinary administration, and of the imperial Treasury with respect to finance ${ }^{3}$.

The Isle of Man was for many years a base for smuggling into England, and continued to be so long after the customs were taken under the control of the customs serviee of the United Kingdom.

The imperial Parliament in $1 ; 67$, immediately after the purchase, in order to stop smuggling passed an Act fixing the customs duties for the isle, and requiring them to be collected by imperial officers. This system has continued, but now under a recent Act the imposition, variation, or abolition of any customs duty fixed by the Court of Tynwald, with the approval of the imperial Treasury, comes into force at onee for six months, but requires for its permanency confirmation by a subsequent Act of the imperial Parliament ${ }^{2}$.

In other respects the taxation of the island is quite independent of the taxation of the United Kingdom. No contribution is made by the island towards the army, navy, or militia, the maintenance of the Crown, the diplomatic service, or the National Debt; but the island has now a force of Volunteers which it in part maintains.

Until I 866 the surplus revenue of the island was paid into the imperial Exchequer, but in that year an agreement was made by which payment of $E_{10,000}$ a year should be made out of the surplus revenue to that Exchequer, which sum 
may be treated either as interest on the purchase money paid Си. III. for the island, or as representing the surplus income of the island before 1866, while the rest of the surplus is applied for the benefit of the island. The general result is that, though the imperial Treasury still controls the finanees of the island, the Tynwald is practically left to manage them in its own way, so long as the customs duties are not such as to lead to snumgling into the United Kingdom.

Like the Channel Islands, the Isle of Man is not bound by an Act of Parliament unless the Act is expressly, or by necessary implication, extended to it.

British India is in no sense a colony, even with the exten- British sion commonly given to that word, but is a dependency India. acquired partly by conquest, partly by cession.

It is beyond the seope of this work to give a history of the various stages by which the present government of India was reached. That history is full of practical lessons in the government of dependencies with an oriental population, lessons both from failure and from suecess ${ }^{2}$.

It is only by a study of that history that much in the Outline of present position of the Indian Government can be fully underlistory. stood; a meagre outline can alone be given here?

In the beginning the East India Company, chartered by the Crown with a monopoly of trade, reeeived power to govern the members of the Company who engaged in the trade and their employees, to make by-laws for them and punish a breach of the by-laws by fine and imprisonment. Then, when the Company established factories, the Governor and comeil of the factory received power to judge all persons in the factory in civil and criminal cases.

$129 \& 30$ Vict. c. 23.

2 The listory of British India illustrates the doctrine that no sulject of the Crown can acquire dominion except on behalf of the Crown, see Camplucll v. Hall, 20 St. 'Tr. 239 ; preamble to 53 Geo. III. ‘. 155; and resolution of IIouse of Commons of May ro, I 773, quoted by Illert, op. cit., p. 53 , note 4 .

3 For at slort summary of the lisiory of the government, see ibicl., ch. i. 
Cr. III. Power was then given to the Company to raise land and naval forces and to govern them by martial law, to coin money, to create municipal bodies, and (in effect) to make war and peace.

Next the Company took over powers of government from the ruling powers in India, and became in practice territorial sovereigns, though the sovereign power continued to be exercised in the name of the Indian ruler. Thus the Company held courts deriving authority from the native Indian rulers, and not from the British Crown.

The courts established by the Company under the royal charter were largely superseded by the courts for exercising jurisdiction over Europeans, which were established under imperial Acts with judges appointed by the Crown.

Parliament also authorized the Company to raise a European army, and passed a Mutiny Act for the government of that army.

The factories developed into presidencies, each with its own governor and council, while after a time the Governor of the Presidency of Bengal and his council developed into a Governor-General and council, with control over the other presidencies and over the relations with native Indian states.

Legislative powers were conferred by Parliament on the Governor-General in Council over all British India and over the servants of the Company everywhere, subject to disallowance of any ordinance by the Court of Directors of the Company. In 1833 one member, and in 1853 several members, were added to the Council for logislative purposes, so as to make the Legislative Council of the Governor-General a body larger than and therefore different from his Executive Council. [The constitution of the Legislative Council was further altered in 1892.$]$

Home

Government of British India.
In $x 784$ a special department of the King's Government, called the Board of Control, was established to attend to Indian affairs and to control the Court of Directors of the East India Company. The government of British India, so 
far as it was exereised in England, was thus of a dual Crr. III. character, resting partly with the Company and Court of Direetors and partly with the Crown acting through the Board of Control. It would, perhaps, be more correet to say that the establishment of the Board of Control emplasized and organized the dual character rather than ereated it, as for many years previously the Crown, either through the Ministers of State or through Parliament, had excreised control over the Indian Government.

In 18 I 3 the trade monopoly of the East India Company was abolished, and Europeans were allowed to settle in India under license. In 18,33 the license system was abolished, the right to trade and settle in India was made iree to every one, and the Company was prohibited from trading and beeame solely a body for the internal government of India.

Finally, in $185^{8}$, after the suppression of the great mutiny of the native army, Parliament abolished the Company and vested in the Crown the sovereignty and direct government of British India ${ }^{l}$; and it is now governed in the name of the King.

An additional Secretary of State was appointed to take charge of the internal government. IIe is aided by a Comeil of India, of from ten to fifteen members appointed by him, who hold office for ten years, and of whom nine must have served or resided in British India for at least ten years ${ }^{2}$. He is also aided by a staff of permanent officers similar to those of the British Civil Service.

The relations between the Seeretary of State and the Council of India are intricate, but in substance the Council are only a consultative body, while the power and responsibility rest with the Seeretary of State. He has to sign every order or communication sent to the local government of

'21 \& 22 Vict, c, 106.

ilid., ss. 7-13; 32 \& 33 Viet. c. $97 ; 52$ \& 53 Vict. c. 65. Tho silirios of the Secretary of State and Council and of the suhordinate staff at the India Office aro paid out of the revenues of British India. 
Cr. III. India ${ }^{1}$, and is responsible to Parliament for all his acts and orders.

Local government of British India.

'British India' must be carefully distinguished from 'India.' The former includes only places in the King's dominions, while 'India' includes, besides British India, the territories of any native prince or chief under the suzerainty of His Majesty exercised through the Governor-General of India or through any governor or officer subordinate to that Governor-General ${ }^{2}$. The position of these latter territories will be noticed elsewhere.

By reason of these dependencies British India would, as before observed, be itself an empire if it were not a dependeney of the British Crown. This imperial position was recognized in the title of Empress of India (translated in India into Kaiser-i-Hind), assumed by Queen Victoria in $1876^{\circ}$.

Further, apart from its dependencies, the local government of British India is of the federal type, that is to say, it has a central legislature and executive, while in sundry portions of it there are local legislatures and executives. Consequently the legislative and administrative powers are distributed between the central and the local governments.

The central government consists of the Governor-General in Council, in whom is vested, both by the terms of his commission and by imperial Act, the superintendence, direction, and control of the civil and military government of India ${ }^{4}$.

Governor- The Governor-General, who is appointed by the King under General of India. Royal Sign Manual to hold office during pleasure, is thus, what no governor of any other British possession is, a Viceroy ${ }^{5}$. But he is bound, both by his commission and by imperial Act, to pay due obedience to all such orders as he may receive from

\footnotetext{
1 2I \& 22 Vict. c. 106, s. 19.

${ }^{2}$ See Interpretation Act, 1889 ( $52 \& 53$ Vict. c. 63), s. 18 (5).

3 Under the Act 39 \& 40 Viet. c. 10 : see the London Gaztte, April 28, 1876 . + 2 I \& 22 Vict. c. 106, s. 29.

${ }^{5}$ See ch. vi. p. 102, infra ; 13 Geo. III. c. 63 , s. $9 ; 3 \& 4$ Will. IV. c. 85 , s. 39 ; and Commission of Governor-General in Appendix IV, p. 232, infra.
} 
the Seeretary of State, and must keep the Secretary of State Crr. III. constantly informed of all matters relating to India. $\mathrm{He}$ is also subject to various restrictions contained in divers imperial Acts $^{1}$, and in particular is prohibited from engaging in war or making a treaty for guaranteeing the possessions of any state, except by the express command of the Secretary of State or for purposes of defenee.

The Governor-Gencral cannot as a rule act against the advice of the majority of his council. The ordinary members of this council, five or six in number, are appointed by the Home Government, and three of them must have served the Crown in India for at least ten years. The commanderin-chief of the military forces in India, who is appointed by the Home Government, may be, and usually is, appointed an extraordinary member of the council; and if the council were to sit (which it never does) in the Presidency of Bombay or Madras, the Gorernor of the Presideney would become an extraordinary member of the council .

The Governor-General and his council hold executive and Central legislative meetings ${ }^{3}$, but at the latter the council is enlarged legislaby the addition of the Lieutenant-Governor or Chief Com- India. missioner of the province in which the meeting is held, and of from ten to sixteen nominees of the Governor-General who hold office for two years, and of whom half at least must not be in the service of the Crown in India. Five of these nominees are appointed on unofficial recommendations, namely, one on the recommendation of the unofficial members of cach of the councils of Madras, Bombay, Bengal, and the NorthWestern Provinces, and one on that of the Calcutta Chamber of Commerce ${ }^{4}$.

1 These Acts were passed with referener to the old dual government of the East India Company and the Crown, hut, though Iargely inapplieable to the present constitutional relations of the Governor-fieneral and the Secretary of State, remain unrepealed.

24 \& 25 Viet. $\because 67$, ss. 3, 9.

'In the colonial constitutions of the r8th ecntury the governer's cruncil often actel in both an ex'entive and legislative character.

1 $24 \& 25$ Vict. c. 67 , ss. 9-11; $33 \& 34$ Vict. c. 3 , s. 3 ; $55 \& 56$ Viet. c. 44 , 
Сн. III. The legislative power of the Governor-General in Council depends on imperial Acts, and has been extended, beyond the territorial limits of British India, to all British subjects, and servants of the Government of British India in any part of India (in the wide sense of the term), and to native Indian subjects (i.e. natives of British India) in any part of the world, and to the Indian marine service; but the power is limited so as to exclude legislation altering the constitution of the Indian Government, or authorizing loans to be raised in the United Kingdom ' .

The Governor-General's sanction is required for the proposal of legislation touching finance, religion, military and naval forces, or the relations of the Government with foreign princes or states. Nothing but legislative business can be transacted at legislative meetings of the Governor-General in Council except that rules of the Governor-General, approved by the Secretary of State, may authorize a discussion of the annual financial statement of the Governor-General, and the asking of questions ${ }^{2}$.

Local

Governments in India.
Passing to the local Governments, they vary according to the provinces. In the Presidencies of Madras and Bombay, there is a Governor appointed by the Home Government, and a council of two members appointed also by the Home Government from among Indian officials ${ }^{3}$.

The Governor cannot, as a rule, act against the advice of

s. I ; and Regulations of the Governor-General made under the latter Act, and printed in Ilbert, Govt. India, p. 337.

1 See $3 \& 4$ Will. IV. c. $85 ; 24$ \& 25 Vict. c. 67 , s. $22 ; 28$ \& 29 Vict. c. 17 ; $3^{2} \& 33$ Vict. c. $98 ; 33 \& 34$ Vict. c. $3 ; 47 \& 48$ Vict. c. 38 , ss. $2-5 ; 55 \& 56$ Vict. c. I4, s. 3. The power to legislate for native Indian subjects when outside India is a larger extra-territorial power than is possessed by the legislature of any other British possession.

The Governor-General alone, in cases of emergency, has the same legislative power as the Governor-General in Council, but a law so made by him lasts for six months only (24 \& 25 Vict. c. 67, s. 23 ).

${ }^{2} 24 \& 25$ Vict. c. 67 , s. 10; $55 \& 56$ Vict. c. 14, s. 2. The present rules are printed in Ilbert, op. cit., p. 348 .

3 The appointment is by warrant under the Royal Sign Manual, countersigned by the Secretary of State; the number may be fixed by the Secretary of State, but is not to exceed three. 
the majority of the council. The Governor and council hold Cr. III. both executive and legislative meetings, but at the latter the couneil is enlarged by the addition of from eight to twenty nominees of the Governor, of whom at least one-half must not hold office under the Crown in India.

The other provinees are under either Lieutenant-Governors or Chief Commissioners, who are appointed by the GovernorGeneral from among Indian oflicials, and act without any executive council.

For each province under a Lieutenant-Governor there is a legislative council consisting of the Lieutenant-Governor and not more than twenty persons nominated by the LieutenantGovernor, with the approval of the Governor-General ${ }^{1}$.

An Act passed by a local legislature ean be vetoed by the Governor, or Lieutenant-Governor, but even if assented to by him does not become law until assented to by the GovernorGeneral; and when so assented to can be disallowed by the Home Government like a law passed by the Governor-General in Council.

A local legislature cannot alter an imperial Act, nor (without the previous consent of the Governor-General) an Act of the Governor-General in Council, nor affect the customs or general revenue of British India, or currency, post office, penal code, religion, patents, copyrights, naval and military forces, or the relations with foreign states; but otherwise has full legislative power ${ }^{2}$.

A provinee under a Chief Commissioner is administered by the Commissioner without any council, and for such a provinee the Governor-General in Couneil in legislative session is the leçislative authority.

To the more backward parts of India the ordinary law and the ordinary methods of legislation are unsuitable. Special

$124 \& 25$ Vict. c. 67 , ss. 44,$48 ; 55$ \& 56 Vict. c. $x_{4}$, s. r, which anthorized the Governor-Goneral in Council, with the appmoval of a Secretary of Statre, to create new Lieutenant-Governors; but it has been questioned whether this powor is not exlatusted.

${ }^{2} 24 \& 25$ Viet. c. 67 , ss. 42-8; 55 \& 56 Vict. c. 14, s. 5 . 
Cr. III. provision has therefore been made for any part of India to which the Secretary of State and Council of India declare such provision to be applicable. As respects any such part the chief executive officer of the provinec, whether Governor, Lieutenant-Governor, or Chief Commissioner, may propose, and the Governor-General in Council in executive session may approve, a law for that part; and the law so approved has the samc force, and is subject to the same disallowance as if it were a law passed in legislative session ${ }^{1}$.

Com-

parison between governments of British India and of other possessions.
The government of British India camnot properly be compared with that of any other British possession, as the conditions are so widely different.

Not only do the area and population exceed those of any other possession, but in British India there are found ancient civilizations and religions, highly organized, as well as barbarous communities, and a large number of different languages and customs; while in areas intermixed with British India there are native sovereigns of very ancient descent still ruling under British suzerainty many millions of people.

The central executive and legislature of British India have, therefore, in some respects larger powers than those of any other British possession. The executive has, as the paramount authority in India, powers outside the British dominions, powers of making treatics and acquiring territory, and practically of making war and peace. It also has powers derived, not from the British Crown, but by succession from the Indian sovereigns whom the Company and the British Crown have displaced ${ }^{2}$.

The wide extra-territorial powers of the central legislature have been already noticed. There are no elective and thercfore truly representative members of any of the legislatures: all the members are nominees of the Home Government or the Governor-General ${ }^{3}$.

33 \& 34 Vict. c. 3 .

2 See Ilbert, op. cit., p. 179.

3 In some of the legislatures there are members nominated on the recommendation of elective bodies. 
On the other hand, the government of India is much more CII. III. regulated, and its executive and legislative powers are more restricted by imperial Acts, than the government of other British possessions. The restrictions enacted for the East ment of India Company and their governors and offieers apply to the Secretary of State and to the Governor-General and governors appointed by the Crown: Thus the King on the advice of a Secretary of State can remove any officer of the Crown in India.

The finanees of India are directly eontrolled by the Secretary of State, and no appropriation of money out of the revenues of India can be made without his permission and the concurrence of a majority of the Conneil of India.

The accomnts of the Indian finances have to be laid before Parliament, and there is an annual debate upon them. A loan cannot be borrowed in the United Kingdom withont the consent of Parliament, nor can money be spent on military operations beyond the frontiers of British India without that consent.

In practice the Home Government, whether through Parliament or the Secretary of State, exercises much more control over the details of the government of British India than it does in the case of a self-governing colony; although the local Government of the latter has in many respects less power than that of British India.

While the government of British India continued in the Courts of East India Company there were, as before mentioned, two sets Justico of courts. The one set consisted of courts of the Company held partly under charter, partly under their powers as collectors of revenue and territorial sovereigns derived from native Indian rulers. 'The other set comprised courts held under eharters issued by the Crown in pursuance of an imperial Aet of $1773^{1}$.

Speaking broadly, the Company's conrts exercised jurisdiction civil and criminal over the natives, the Crown courts over Europeans.

$$
113 \text { Gieo. III. c. } 63 .
$$


Cr. III. After the assumption by the Crown in 1858 of the whole government of British India, charters issued by the Queen under the authority of an imperial Act established in the towns of Calcutta, Madras, and Bombay, High Courts for the provinces of Bengal, Madras, and Bombay, and amalgamated the two sets of courts. Subsequently a fourth High Court for the North-Western Provinces was established at Allahabad.

The other courts in British India are established by the local Governments under Indian Acts; in these the judges are members of the Indian civil service, who may be, but usually are not, natives of India.

The judges of the High Courts are appointed by and hold office during the pleasure of the Home Government, which also fixes their number, salaries, furloughs, and pensions ${ }^{1}$.

The jurisdiction of these High Courts is in the main fixed by the charters; and an appeal lies from them to the King in Council.

They have original civil and criminal jurisdiction within the limits of the provinces for which they are appointed, and in certain cases outside those limits; they have also a general superintendence of the local courts and are courts of appeal from them.

Until i 872 a European British subject could only be tried before a High Court; and though he can now be tried before a district judge, if a European he has still certain privileges as regards jury and otherwise which native Indians have not ${ }^{2}$.

1 This tenure of high court judges during pleasure is contrary to the principles of English law (see 12 \& r3 Will. III. c. 2, Act of Settlement), which are generally followed in the British possessions. In practice, however, the judges hold during good behaviour. One-third of the judges of each high court must be barristers or advocates of the United Kingdom of not less than five year's' standing, and one-third inust be Indian officials of not less than ten years' standing, and with not less than three years' experience as district judges. The total number is limited to fifteen for each court, $24 \& 25$ Vict. c. IO4, ss. 2, I9.

2 Strachey, India, pp. I55 seq. 
The extent to which, and the time at which, English law

has been introduced in British India have been the subject of controversy and legal decision ${ }^{1}$, but the matter is now largely settled by the enactment of the Indian codes ${ }^{2}$.

But in civil matters, particularly inheritance, succession to lands or goods, marriage, and to some extent, even in ordinary contracts, the local or personal law or custom remains, and the personal law or custom applied is, if both parties are not under the same law or custom, that of the defendant.

One very important part of the central government which Military does not exist, at least to the same extent, in any other India. British possession, is the army, which consists partly of British troops, sent from England, partly of native troops raised in India, but officered in part by British officers. The British troops are a part of the 'regular forces,' and remain under the government of the imperial Army Act. The native troops are governed by Indian law. The whole of them are under the command of a commander-in-chief appointed by the King under the Royal Sign Manual, and in the main are governed by him independently. The commander-inchief has to comply with the instructions given by the Governor-General in Council, just as a general in England has to comply with the instructions given him by the Crown through a Secretary of Statc; but in purely military matters he is independent of the Governor-General and is responsible to the Home Government only ${ }^{3}$. Many of the native Indian

1 Mayor of Lyons v. East India Company, r Moo. P. C. 176, 3 St. Tr. N.S. 647 (see notes in latter report); Freeman v. Fairlie, I Moo. Ind. App. 305, 2 St. Tr. N.S. 1000 ; Sir J. Stephen's Nuncomar and Impey, vol. ii. p. 18; Illerert, op. eit., p. 34 .

2 The Penal Code, the Code of Criminal Procedure, the Code of Civil Procedure, and the Indian Contract Aet. The Succession Act of 1865 applies almost exclusively to Europeans. [For an account of codification in India, see Ilbert, Legislative Methods and Forms, pp. 129-55.]

3 The Indian Government cannot raise il separate army of Europeans, $23 \& 24$ Viet. $\bullet$ roo. The Governol-General cannot issuo a military commission, Ilbert, Giont. India, N1. 271-5. Lord Ellenborough, when Governor(iencral, asked for the right to have the command of the army, but was refused. Lord Inardinge hiad the right given him, and at one time took 
Crr. III. rulers maintain military forces, under certain restrictions as to numbers and arms imposed by the Governor-General. Some of them maintain a force better armed and available for service under the orders of the Governor-General for places outside the limits of the native state in which they are raised.

Indian

Civil Service,

British India has another peculiarity in having the government administered by a highly organized permanent civil service which consists (roughly) of two divisions, the ' civil service' formerly called the 'covenanted service ${ }^{1}$ ', and the 'provincial service' corresponding to what was called the 'uncovenanted service.' All the more important posts in the old 'regulation' provinces are reserved by imperial Act to the civil service except under very special circumstances ${ }^{2}$. In the 'non-regulation' provinces all offices are open alike to native Indians, to military officers who are members of the staff corps, and to members of the civil service.

Members of the civil service are appointed by the Secretary of State from among those who succeed in a public literary examination, held annually in London, and open to all natural born British subjects under the age of twentyfour. The candidates selected at this examination afterwards pass a probationary year, and comply with certain requirements, such as learning to ride on horseback, and learning Indian law ${ }^{3}$.

over the command of the army from Lord Gough, but this was by virtue of his military rank and length of service; see Life of Peel, vol. ii. pp. 20, 300.

The independent commanders-in-chief in Madras and Bombay were abolished in 1893 by $56 \& 57$ Vict. c. 62.

1 'Covenanted service' is a term derived from the covenant entered into by the appointees, formerly with the East India Company, and now with the Secretary of State, not to trade, not to receive presents, to subscribe for pensions, \&c. Strachey, Intia, p. 257, n. 3. See form of covenant, Ilbert, op. cit., p. 593 .

${ }^{2} 24 \& 25$ Vict. c. 54 . 'The 'regulation' provinces are Bengal, NorthWestern Provinces, Madras, and Bombay, Struchey, p. 445 ; Ilbert, op. cit, pp. 105, 135, 277 .

${ }^{3}$ I I \& 22 Vict. c. 106, s. 32, and rules made under it by the Secretary of State in Council of India. 
When once appointed, they rise partly by seniority and Cir. III partly by promotion, until they can, after twenty-five years' service, retire with a pension. They practically hold during good behaviour, though any of them ean be removed at will by the Home Government. They can be suspended by the local Government of India, but cannot be removed without the approbation of the Home Government.

Although in $1 \delta_{33}{ }^{1}$ Parliament declared that a native of India should not by reason of his religion, descent, place of birth, or otherwise, be disqualified for office, yet the covenanted service continued in fact to be filled wholly by European British subjects.

Even after Parliament in $1853^{2}$ threw open the covenanted service to public competition, only a few natives, owing to the examination being held in London, succeeded in the competition. Parliament in 1870 passed an Act ${ }^{3}$ for facilitating the employment of Indian natives. Under that Act rules for the purpose were made in 1879 , and, on their failure, also in I 889. Under the latter rules the provincial service consists almost entirely in each province of natives of the province selected in a manner suitable to local circumstances.

Of the total number of civil employees in India, ninety per cent. are natives. The offices held by the 'civil service' are under 1,000 , and if these posts (which are mostly the higher posts) are excluded, there are nearly 3,c00 superior administrative and judicial offices, most of which are held by natives of India. The officers of the army, whether European or native, are not included in these figures.

The population thus governed is about 221 millions in British India, besides 67 millions in the native states, in which some of the officers composing the staff are employed ${ }^{4}$.

3 \& 4 Will. IV. c. 85 .

${ }^{2} 16 \&$ I 7 Vict. c. 95.

${ }^{3} 33 \& 34$ Vict. c. 3. For the rules under it, see Strachey, op. cit., p. 258; Ilbert, op. cit., p. 127.

4 Sce Strachey, op. cit., P. 285; Ilbert, op. cit., r. 128 ; India Office List. 


\section{CHAPTER IV}

\section{SELF-GOVERNING COLONIES}

Cr. IV. THE constitutions of the self-governing colonies differ The amongst themselves in many points of detail, but vastly problem of more important than any analysis of differences is the colonial examination of those common principles which underlie the
selfgovernment. structure of all alike. The problem of colonial self-government is the problem of reconciling local parliamentary institutions framed after the English model with the supremacy of a Parliament at home in which the colony has no voice. To appreciate the difficulties of the problem and the form which its solution takes it is necessary to bear steadily in mind that feature of the English Constitution on which Professor Dicey has laid such stress-the essential supremacy of the legislature in our system, with the two results, (I) that the English executive is responsible to the legislature, and dependent on the will of the majority in the popularly elected House; (2) that the English judiciary has merely to interpret and apply legislative enactments, never to declare them invalid or beyond the competence of the legislature to enact. The second of these results is due to the fact that the sphere of legislative power in the English Parliament is unlimited in extent and undisputed by any rival law-making authority-that Parliament is a sovereign law-making body, in fact-and therefore obviously cannot be reproduced in a self-governing colony, where legislative powers are limited and Imperial statutes of superior force. Consequently the courts of a self-governing colony have of necessity a function not found in their proto- 
type, the function of deciding on the validity as well as the $\mathrm{C}_{\text {r. IV. }}$ meaning of colonial statutes.

But the first of the two results above indicated, namely, the dependence of the executive on Parliament, is perfectly consistent with a restricted range of legislative power, and therefore is reproduced in a self-governing colony without difficulty. Such a colony has more than representative government; its characteristic feature is not merely a control of local taxation and an influence over local legislation exercised by a popularly elected Chamber. Such a colony has also responsible government: i.e. the heads of administrative departments form a ministry which continues in office only so long as it commands the confidence of the legislature.

It is this dependence of the colonial Executive on the Meaning colonial Parliament which constitutes at once the essential of respon resemblance between the constitutions of our self-governing $\begin{aligned} & \text { govern- } \\ & \text { ment. }\end{aligned}$ colonies and that of the mother country, and the essential divergence between the constitutions of our self-governing colonies and all foreign systems. From this point of view, at any rate, the charge of 'official mendacity' brought by a learned writer ${ }^{1}$ against the preamble of the British North America Act, $1867^{2}$ (because it recites the wish of the Canadian provinces to be federally united into one Dominion ' with a constitution similar in principle to that of the United Kingdom') cannot be sustained. His criticism that this statement would only be true if 'United States' were substituted for ' United Kingdom' ignores a distinction far more significant than any analogies based on features common to all

1 Dicey's Law of the Constitution, Ist ed., p. r53. In tho $4^{\text {th }}$ ed., p. I56, the expression is ehanged to 'diplomatic inaccuracy, thougl tho author still maintains that 'it is clear that the Constitution of the Dominion is in its essential features modelled on that of the Union,' explaining that he is regarding the Dominion solely from the federal point of view. But even if wo shut our eyes to the erucial distinction between parliamentary government and presidential government, the points of rosemblanco between Canada and the United States aro not nearly so remarkable, it is submitted, as the points of difference. $\Lambda$ s to this, see below, p. 90.

30 Vict. c. 3 . 
Crr. IV. federal constitutions. In the Dominion of Canada, no less than in every other self-governing colony in the cmpire, the system of government is that of responsible, or what has been termed 'parliamentary' or ' cabinet' government, just as in the United Kingdom. The executive power is vested in the Crown, but is wielded by ministers who, though appointed by the Governor-General as delegate of the Crown, necessarily require the support and confidence of a majority of a popularly elected assembly, and are consequently responsible to that assembly. In the United States, on the other hand, the executive is in no sense dependent on the legislature. The President is elected by the people, and appoints for the administration of government ministers who are never members of the legislature, who need not enjoy the confidence of the majority of the legislature, and who are responsible to the President alone, and not to the legislature.

Informal origin of responsible government.

It is the more important to insist on this fundamental characteristic of the self-governing colonies, because it is not to be discovered by an examination of their 'instruments of constitution.' Whatever be the form which these documents assume 1, they will be found in every case to concern themselves mainly with the establishment of colonial legislatures, and to be silent, or almost silent, as to the relations between legislature and executive. The circumstance is highly significant of the vogue, in the self-governing colonies no less than in England, of what has been termed the 'rule of law.' Just as in England parliamentary government arose, without any formal constitutional change, from William III's recognition of the necessity of choosing ministers of homogeneous opinions, able to command the support of a parliamentary majority, so in the self-governing colonies the change from merely representative to fully responsible government is due, not to imperial legislation or formal prerogative orders, but to private instructions from the Colonial. Office to the Governor, directing him to select his ministers from the predominant

1 See Appendix I. 
party in the legislature, on the understanding that they will Crr. IV. give way to their successors when they lose the parliamentary support which pointed them out for ofice ${ }^{1}$.

Thus the date of the introduction of responsible government Origin of into a colony is not as a rule to be discovered in Acts of responParliament or Orders in Council. To take the earliest governinstance, Lord Durham's famous report, the result of his Canada. appointment as Governor-General and High Commissioner after the Canadian rebellion of $1837-8$ and the suspension of the Constitution of Lower Canada ${ }^{2}$, was presented to Parliament in 1839 , and recommended-(I) the union of the two provinces, and (2) the introduction of responsible government. The Union Act introduced by Lord John Russell, setting up one nominated legislative council and one elected legislative assembly for the whole colony, became law in I $8+0^{\circ}$, and this therefore is the date of representative institutions in the reunited province. But the legislative machine was at work for some years before responsible government began. 'Up to July, I846,' wrote the statesman to whom self-governing colonies chiefly owe their autonomy, 'the problem of bringing into satisfactory operation this system of administration had certainly not been solved'4. Section 45 of the Union Act of 1840 (the only section in an instrument of constitution of sixty-two clauses which deals with the colonial Executive) merely refers to 'such executive council ... as may be appointed by Her Majesty for the affairs of the Province of Canada,' and is silent as to the principle on which

${ }^{1}$ Cf. C. O. R. 57, and 1) 92 infr. In the two self-governing colonies of Sonth Africa the introduction of responsible govermment may be referrerl to a colonial statute-in Cape Colony to Act No. I of 1872, amending the Constitution Ordinance of 1852 , and in Natal to the Constitution Act, No. 14 of 1893 . But even in these cases tho enactments only hint faintly at the parliamentary control of administration. see below, p. 63.

2 I \& 2 Vict. c. 9.

${ }^{3} 3 \& 4$ Vict. c. 35 . From I 79 I to 1837 cach of the two provinees enjoyed

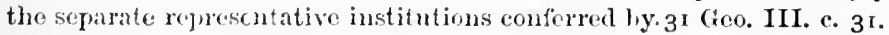

- Earl Grey's Colonial Policy of Lord Jolin Iussell's Administration, vol, i. p. 203 . 
Cr. IV. appointments are to be made. In I84I Lord John Russell instructed the Governor-General to call to his councils 'those persons who by their position and character have obtained the general confidence and esteem of the inhabitants of the province,' and it was not till $\mathbf{I} 847$ that Lord Elgin was expressly instructed 'to act generally on the advice of the executive council, and to receive as members of that body those persons who might be pointed out to him as entitled to be so by their possessing the confidence of the Assembly'.

In the North American colonies, therefore, representative institutions, dating back in the case of the old provinces of Canada to $179 \mathrm{I}^{2}$, and in the case of Newfoundland to $183^{2}$, were silently transformed, without formal constitutional change, in the decade 1846 to 1855 into a system of responsible government. Even so late as 1867 , though the British North America Act ${ }^{3}$ recites that 'it is expedient, not only

1 Quoted by Munro, Constitution of Canada, p. 20. An even more instructive instance of the adaptation of parliamentary government to a colony which had already received representative institutions is furnished by Earl Grey's dispatch, dated Nor. 3, r846, to Sir John Harrey, Lieutenant-Governor of Nova Scotia (House of Commons Sessional Paper, No. 621 of 1848 , p. 8, set out in Earl Grey's Colonial Policy, vol. i. pp. 209213). Sir John had reported that there were vacancies on his Executive Council, but that he was urged by members of the opposition to dissolve the assembly and hold a general election. Grey directed him, however, to fill up the vacancies by calling upon 'the members of your present Executive Council to propose to you the names of the gentlemen whom they would recommend.' If they fail to form a complete council, the Governor is to apply to the opposite party, and only if the opposition also fail to form a satisfactory council is he, on their advice, to dissolve the assembly. 'The object with which I recommend you this course,' the Colonial Secretary goes on, 'is that of making it apparent that any transfer which may take place of political power from the hands of one party in the Province to those of another is the result, not of any act of yours, but of the wishes of the people themselves, as shown by the diffieulty experienced by the retiring party in carrying on the government of the Province according to the form of the Constitution. To this I attach great importance; I have therefore to instruct you to abstain from changing your Executive Council until it shall become perfectly clear that they are unable, with such fair support from yourself as they have a right to expect, to carry on the government of the Province satisfactorily, and command the confidence of the Legislature.'

2 3I Geo. III. c. 3 I.

${ }^{3}$ зо Vict. c. 3 . 
that the constitution of the Legislative Authority in the Crr. IV. Dominion be provided for, but also that the Nature of the Executive Gorernment therein be declared,' yet Parliament was content to provide ${ }^{1}$ that there should be a Privy Council for Canada, consisting of members 'from time to time chosen and summoned by the Governor-General,' and left unexpressed the fundamental requirement that the Governor-General should select ministers from the party in the majority in the Lower House.

Much therefore that is at the very root of the constitutions Unwritten of our self- constituof our self-governing colonies is unwritten, though it is none tional the less constitutional because its origin lies in a practice custom which is nowhere formally recorded, and which develops nerw colonies. rules in the course of years. The genius of Earl Grey not only devised for the greater colonies a system of government which reproduced as nearly as possible the external features of our own, but (in spite of the restrictions which a written constitution tends to impose) breathed into the copy the inner essence of the original-the possibility of silent constitutional growth. And while colonial instruments of constitution lay down in express terms many rules (especially in connexion with legislative practice) which in England are inwritten, yet much of the autonomous system of government in the colonies remains based, as in England, on unenacted custom, and some unwritten conventions have been developed in the colonies which are hardening into constitutional rules without a counterpart in this country.

As an example of the reproduction of the unvritten consti- Some contutional conventions of England in the form of enacted rules of the of a colonial constitution, the provisions of the British North English Ameriea Act regarding money Bills may be noted. The rule tion rethat a money Bill must originate in the popularly-elected enpear as law in the colonies.

1 Sect. Ir. Cf. the provision in clause 62 of the Constitution of the Australian Conmonwealth, $63 \& 64$ Vict. c. 12 . On the other hand, there is no mention of an Executive at all in the New Zealand Constitution ( 5 \& 16 Vict. c. 72). Seo below, p. 62. 
Crr. IV. House, and the rule that such legislation must be preceded

(I) Rules as to money Bills.

by a recommendation from the Crown, are both specifically enacted ${ }^{1}$. On the other hand, a third rule-that every money Bill must begin in a committee of the whole House-is an uncnacted convention, prescribed by nothing but long eustom and a Standing Order, at Westminster and Ottawa alike ${ }^{2}$. Similarly, the Commonwealth of Australia Constitution Act ${ }^{3}$ provides that money Bills shall not originate in the Senate ${ }^{4}$, and that the Governor-General's recommendation is necessary ${ }^{5}$; but it adds two further rules not expressed in the Canadian Constitution, namely, that the Senate may not amend money Bills ${ }^{6}$, and that laws imposing taxation shall not deal with any other subject matter ${ }^{7}$. In the New Zealand Constitution of 1852 the only rule regarding money Bills which is expressly enacted is the requirement of the Governor's recommendation to the House of Representatives ${ }^{8}$. In New South Wales both this rule and the rule that Taxation and Appropriation Bills must originate in the Legislative Assembly are laid down in the constitution scheduled to the imperial Act

1 so Vict. c. 3 , ss. 54 and 55 ; and ef. s. 9o. The only written security for the observance of the second of these rules by the imperial Parliament is Standing Order 57. The first may be read in a resolution of the Commons of 1678 , 9 Com. J. 509. But the real basis of both is of course unwritten; and, what is not the same thing but more important, neither rule is in England a 'law' in the sense that an English court would recognize its validity, whereas in Canada both rules are 'laws' in the strictest sense.

2 The Standing Order of the imperial Parliament was agreed to in 1707. See Anson, L. and C., vol. i. p. 257. The Canadian Standing Order is No. 88. Cf. Mumro, Constitution of Canada, p. 153 .

${ }^{3} 6_{3} \& 64$ Vict. c. 12.

4 Clause 53 of the Constitution (which is set out in s. 9 of the Act).

${ }^{5}$ Clause 56 of the Constitution.

- Clause 53 of the Constitution. The clanse does not prohibit the Senate from rejecting a money Bill, though it was the exercise of this power by the House of Lords in I860, which necessitated Mr. Gladstone's three resolutions. The section concludes with a provision which has no counterpart in English practice-that the Senate may at any stage return a money Bill to the House of Representatires, with a request for omission or amendment of any items or provisions therein.

7 Clause 55 of the Constitution.

8 I5 \& 16 Vict. c. 72 , s. 54 ; cf. s. 25. 
of $\mathrm{I} 855^{\mathrm{x}}$; while the Victorian Constitution, similarly scheduled Cir. IV. to an imperial Act which received the Royal Assent on the very same day ${ }^{2}$, specifically incorporates three rules relating to money Bills- the two just mentioned, and also the rule that such Bills 'may be rejected but not altered by the Council's.

But perhaps the Colonial Constitution which most openly acknowledges the desire to incorporate the unwritten rules of Westminster as to Money Bills into its enacted code, is the Cape Colony Constitution Ordinance of $185^{2}{ }^{4}$, which, besides requiring the recommendation of the Governor for such legislation $^{5}$, deseribes the Bills which must originate in the House of Assembly as 'of such a nature that if bills similar to them should be proposed to the Imperial Parliament of Great Britain and Ireland such bills would, by the law and custom of Parliament, be required to originate in the IIouse of Commons' ${ }^{6}$.

Another instructive set of instances of the inclusion of our (2) Statuunwritten constitutional understandings in written instru- torydefiniments of constitutional law for the colonies is furnished by position an occasional reference to the Executive in these documents. tive. In England the position of the Executive is hardly defined by statute at all, and, as has been above pointed out, even the framers of colonial constitutions have not attempted to reduce to writing the real relations of executive to legislature. Yet

18 \& 19 Vict. c. 54 ; Sched. I. The rules are in clauses I and 54 of the Constitution. The reference in the former to "the limitation contained in clause sixty-two' is apparently intended as a reference to the latter. The same two rules are enacted in the Western Australian Constitution, ss. 66 and 67 , scheduled to 53 \& 54 Vict. e. 26, and in the Queensland $\Lambda$ et, No. 38 of 3 I Vict., ss. 2 and 18.

218 \& 19 Vict. e. 55, Sched. I. These three mles also appear in the Natal Constitution Act, No. 14 of 1893 , ss. 48 to 50.

3 Clauses 56 and 57.

4 Schedulerl to Order in Comncil of March 11, 1853 .

5 Sect. 80 .

- Sect. 88. The section concludes with a proviso giving the Legislative Conucil and the Governor full power to amend a money Bill and to return the Bill so amended for reconsideration. This departure from: English practice is apparently to be explained (like the milder proviso in the Commonwealth of Anstralia Constitution, s. 53) by the finct that tho Uper House is elective. 
Crr. IV. a comparison of the instruments of constitution of the selfgoverning colonies, in order of date, shows that during the last half-century the tendency has been growing to express in the form of written law some part at any rate of the administrative understandings on which responsible government is based. In the earlier instruments there is nothing whatever to suggest that colonial Ministers of State should not hold office during good behaviour ${ }^{1}$, or indeed that the administration of government is to be conducted on the advice of parliamentary chiefs at all. Thus the New Zealand Constitution of $185^{2}$ concerns itself solely with legislative and judicial organization : the relations between legislature and executive are not even faintly indicated, and cabinet government is as much outside the law as it is in England itself ${ }^{2}$. The two instruments of constitution which date from I855, those of New South Wales and Victoria ${ }^{3}$, contain the first inkling of a parliamentary executive in a phrase common to both, and referring to 'the appointments of the officers liable to retire from office on political grounds.' In I 867 Parliament inserted into the British North America Act, by way of partial fulfilment of the recital that it was expedient to declare 'the nature of the executive government,' the provision ${ }^{4}$ that there should be

1 In October, 1839 , Lord John Russell found it necessary, in a dispatch to Mr. Poulett Thomson (House of Commons Sessional Paper, No. 62I of 1848), to explain that for the future Canadian administrators would not hold office during good behaviour, but would be liable to be called on to retire whenever motives of policy rendered it expedient.

${ }^{2} 15$ \& 16 Vict. c. 72 . When the General Assembly first met in 1854 a deadlock resulted, as the office-holders of the old régime were determined to remain as the Executive. Finally it was resolved to apply for an English Act to establish responsible government, but the Colonial office intimated that no enactment was necessary, as the practice rested upon usage. Consequently, after another general election, the New Zealand legislature in $185^{6}$ passed a Pensions Bill for the benefit of existing ministers, and ministerial responsibility then began. Cf. Coghlan, Sexen Colonies of Australasia, 1899-1900, p. r99. The Executive Council is constituted under Letters Patent to the Governor, dated February 22, 1879.

${ }^{3}$ I8 \& I9 Vict. ec. 54 and 55. The phrase referred to occurs in s. 37 of the respective scheduled constitutions. Cf. Anson, L. and C., vol. ii. 1. 270 .

${ }^{4}$ 3o Vict. c. 3, s. Ir. Professor Dicey has pointed out that there is in 
' a Council to aid and advise in the Government of Canada,' to Crr. IV. be styled the 'Queen's Privy Council for Canada,' and that its members should be appointed and might be removed by the Governor-General. The word 'cabinet' does not appear, though the term is commonly applied to the body of acting ministers. In $18_{72}$ the legislature of the Cape Colony passed a 'Constitution Ordinance Amendment Act 1', which recited as its object 'the introduction of the system of executive administration, commonly called Responsible Government,' but the Act leaves the essence of that system to be understood, and contents itself with providing that the five ehiefs of departments may ${ }^{2}$ be members of the legislature, and that the existing administrative heads when they retire from office 'on political grounds' shall be pensioned. The Western Australia Constitution Act, I890, goes a step further, for besides providing that the 'five principal executive offices of the Government liable to be vacated on political grounds' may be held by members of the legislature, it expressly enacts that one of the five "shall always be held by a member' of the Legislative Council 3.' Three years later ' may' has changed to 'must,' and the Natal Constitution Act of $1893^{4}$ enacts that 'every minister shall be, or shall within four months from the date of his appointment become, a member of the Legislative Council or of the Legislative Assembly, but not more than two Ministers may be members of the Legislative Couneil.' The example of putting down in black and white the rule that ministers must sit in Parliament is followed in the Constitution of the Australian Commonwealth, which provides

federal constitutions a tendency to define the division of powers even beyond what federalism necessitates (Law of the Constitution, 1. 142). It is all the more remarkable, therefore, that so littlo is thought suffieient here.

1 No. I of 1872 .

${ }^{2}$ Sect. 3. Similarly in $188_{4}$ the Queensland legislature was content to cnact the eligibility of ministers ( $N 0.29$ of 48 Viet. s. 1 ).

${ }^{3}$ Sect. 6 of the Constitution Act, which is scheduled to $53 \& 54$ Viet. c. 26 ; ef. also s. 28 .

+ No. 14 of 1893 , s. 9 . 
Сн. IV. for ' a Federal Executive Council to advise the GovernorGeneral in the government of the Commonwealth', and enacts that 'the members of the Council shall be chosen and summoned by the Governor-General and sworn as Executive Councillors, and shall hold office during his pleasure ${ }^{1}$ '' Moreover, the officers appointed by the Governor-General to administer during his pleasure the departments of State 'shall be members of the Federal Executive Couneil, and shall be the Queen's Ministers of State for the Commonwealth. After the first general election no Minister of State shall hold office for a longer period than three months unless he is or becomes a senator or a member of the House of Representatives 2.' Thus at last the constitutional understanding which associates political office with membership of Parliament ${ }^{3}$ has become enshrined in the enacted law of a colonial constitution. But the selection and function of a premier, the collective responsibility of a cabinet, the merely nominal activity of ex-cabinet ministers in the executive council, and the dependence of the administration on a majority in the legislature-all these are as far from finding expression even in the latest of colonial constitutions as in the Bill of Rights or the Act of Settlement.

One colonial legislature has indeed gone further in the direction of expressing the truth that departmental ehiefs must resign their positions if they have not a majority of the legislature behind them. This is the legislature of South Australia, a colony whose constitutional enactments are especially well worth study for the sake of their boldness and ingenuity in other respects ${ }^{4}$. The South Australian Con-

1 Clause 62.

2 Clause 64.

3 This constitutional understanding has occasionally suffered a temporary breach in England. From December, 1845, to July, I846, Mr. Gladstone was Secretary for the Colonies without a seat in the House of Commons ; Mr. Goschen became Chancellor of the Exchequer in January, 1887 , but did not succeed in getting returned to Parliament till February; and Mr. Horace Plunkett, though losing his seat in the General Election of September, I900, still (Jan. I902) holds the office of President of the Irish Departmeut of Agriculture.

t e. g. sec s. 16 of South Australia Act, No. 236 of I88r, providing alter- 
stitution Act of $1855-6$ not only requires the five Ministers Св. IV. of State to be members of Parliament, and makes them ex-officio members of the Executive Council ${ }^{1}$ (in fact, of course, they are the only effective members of that.body), but openly admits the fact that they are "liable to loss of office by reason of their inability to become members of the said Parliament or to command the support of a majority of the members thereof or upon other grounds without any misconduct or incapacity' 2 , and therefore provides for a retiring allowance to existing chiefs of departments, who entered on their offices with no fears of the fickleness of the legislature.

The result is that the nature and functions of the execu- The executive in a self-governing colony are, for the most part, but not tive so completely as in England, based on a mere constitutional understanding, the observance of which a parliamentary majority can always enforce. In essentials the parallel between such a colonial Executive and the Executive at home is as complete as the difference between imperial and colonial government allows. But there are variations of detail. Thus, the governor presides over formal meetings of the executive council in a self-governing colony, whereas the Sovereign has not been present at deliberations of an English Cabinet since the death of Annc. Again, the eabinet and the ministry in most of the self-governing colonies are coterminous, though in some, as in Canada, subordinate ministers, such as the solicitor-general, are commonly members of the administration without being members of the eabinet. On a change of government, members of the superseded eabinet in some colonies remain part of the executive council and retain their title of 'Honourable'-just as ex-Cabinet Ministers continuc to be Privy Councillors in England-but of course they take no effective share in the counsels of the new administration.

nativo methods for dealing with a deadlock between the two Chambers of the legislature.

${ }^{2}$ Sect. 32 of No. 2 of $1855-6$ of tho colony.

2 Sect. 39. 
Cн. IV. Colonial constitutions not infrequently declare the number of ministers who may remain members of parliament ${ }^{1}$, and thus in effect fix the size of the cabinet.

The legislature in selfgoverning colonies.

(I) The upper house.

A reference to Appendix I will show that the legislatures of the self-governing colonies which are there analysed, all follow the imperial pattern in consisting of two houses, though of the seven provinces of Canada, Quebec and Nova Scotia alone preserve an upper chamber. In the federal legislatures of Canada and Australia, the upper house is called a Senate: in the unitary legislatures it is called a Legislative Council. In Canada, New South Wales, and Queensland, it consists of members nominated for life by the governor on the advice of his ministry. In Newfoundland legislative councillors are appointed for life by the Crown under the sign manual and signet. In New Zealand and Natal the members of the legislative council are nominated for a term of years. In the other self-governing colonies they are elected: in Victoria, Western Australia, Tasmania, and the Commonwealth of Australia for six years, in the Cape Colony for seven, and in South Australia for nine ${ }^{2}$. In nearly all cases the size of the upper chamber, even when a nominated body, is precisely defined by legislation; but where it is not (as in New South Wales, where a minimum limit of twenty-one is the only restriction imposed) the Government of the day might be tempted to swamp opposition in the

1 Cf. s. 3 of Law No. $x$ of 1872 of Cape Colony; s. 8 of Law No. I4 of I 893 of Natal ; s. 32 of No. 2 of $1855^{-6}$ of South Australia.

${ }^{2}$ In South Australia the governor's power of dissolving the house of assembly 'whenever he may deem it expedient' does not extend to the legislative council (s. 2 of No. 2 of $1855-6$ ), which therefore has a continuous existence, one-third of its members surrendering their places to newly elected substitutes every three years. The only case in which the legislative council can be dissolved arises, after a deadlock between the houses, under s. 16 of Act 236 of 188r. A similar arrangement has been adopted in the Australian Commonwealth. See below, p. 87. The governor has no power to dissolve the council in Victoria. In the Cape he can dissolve both houses together, or he may dissolve the assembly without the council. (Const. Ordinance of 1852 , s. 74 ; ef. Law No. 9 of I897.) 
non-eleetive house by the sudden ereation of additional members, CH. IV. as was done in England in 1712 , and threatened in 1832 . This method was on one occasion adopted in New South Wales, during one of the premierships of Sir Charles Corper, but the home authorities rebuked the governor, Sir Joln Young, for lending himself to the seheme, and the principle was laid down that the number of legislative couneillors should be limited to what is convenient, and 'that no nominations should ever be made merely for the purpose of strengthening the party which happens to be in power' '.

The lower house in all the self-governing colonies is elected (2) Tho by the people upon a wide franchise, which gives a vote to house. nearly every man, or rather to every white man ${ }^{2}$. In South Australia and Nerv Zealand women vote as well as men, and a Female Franchise Bill has also passed the lower house in New South Wales. Only in the Dominion of Canada has the title of 'House of Commons' been conferred on the popular branch of the legislature; in New Zealand and in the Australian Commonwealth it is ealled the 'House of Representatives'; in Newfoundland, South Australia, Tasmania, and the Cape Colony the 'House of Assembly'; and in the other self-governing colonies (as also in all the Canadian provinces) the 'Legislative Assembly.' The duration of the lower house varies in different colonies from five to three years, and it is noteworthy that although recent colonial legislation shows a tendency to shorten the period, 'annual Parliaments' have in no case been established. Among

1 Return from New South Wales at p. 43 of Parl. P., 1889, No. 70.

${ }^{2}$ In New Zealand the legislative council includes two members of tho aboriginal native race, and there are four Maori electoral districts each returning one member to the house of representatives. In tho Capo Colony the franclise is, nominally, open to men of all colours possessing the necessary qualifications, but persons whose only qualification is a share in tribal occupancy are excluded from voting (No. 41 of 1887 ), and the Ballot and Franchise Act, 1892 requires every voter to sign his namo and write his address and occupation. In Canada there is a special franchise for Indians. In Western $\Lambda$ ustralia aboriginal natives of Australia, Asia, or Afriea, ean only vote in respect of a freehold qualificition (57 Vict. No. I4, ss. 12, 21). 
Сн. IV. other points of difference between the legislatures of the selfgoverning colonies and their prototype at Westminster, the following may be noted :-

Differ-

ences

between

imperial

Parlia-

ment and

legisla-

tures of

self-

(I) Mcmbers of a colonial lower house are, in every case except one ${ }^{1}$, paid from public funds. In several of the colonies $^{2}$ members of the upper house are also paid.

(2) Some of the colonies ${ }^{3}$ have adopted the continental plan of giving ministers audience in both houses, though they only vote in the house to which they belong.

governing

(3) The special rules as to money Bills, which in England are at best mere conventions, reappear, more or less exhaustively, in the colonies as a part of their statute law ${ }^{4}$.

(4) The rule that Parliament shall meet every year-the observance of which, in England, is secured only by the necessity of appropriating supplies and of providing for the discipline of the army annually - is reduced to writing, and usually appears as one of the clauses of the instrument of constitution in the self-governing colonies ${ }^{5}$.

(5) It is commonly provided in colonial constitutions that a member of the legislature vacates his seat by prolonged absence. Failure of attendance for one whole session is the usual disqualifying period ${ }^{6}$.

1 In Western Australia the members of both houses serve gratuitously. In Natal members are not paid a salary, but those residing more than two miles from the seat of government receive $\mathfrak{E}_{\mathrm{I}}$ a day as travelling allowance; ef. the provisions of the Cape Act No. I6 of I888.

${ }^{2}$ Members of the upper house are not paid in Queensland, Victoria, N. S. Wales, and Western Australia.

3 e.g. Natal, the Cape Colony. A Bill for this purpose is now under consideration in Sonth Australia.

4 supra, p. 60 .

s e.g. s. 77 of the Constitution Ordinance of 1852 runs: 'And be it enacted that there shall be a session of the Parliament of the Cape of Good Hope once at least in every year, so that a period of twelve calendar months shall not intervene between the last sitting of the said Parliament in one session and its first sitting at next session.' Believers in an unwritten constitution will not fail to note that this explicit provision did not prevent a breach in rgor.

- In South Australia a member loses his seat by absence for two con- 
(6) A colonial member, unlike a member at Westminster, Cи. IV. can resign his seat by written notice, without having recourse to our antiquated method of nominal appointment to disqualifying office.

(7) Ministers are not in some colonies required to submit themselves for re-clection upon their acceptance of office.

The sphere of a self-governing colony's legislative activity Limits to is limited by two considerations: first, by the restriction the legisimposed by its instrument of constitution, which defines the power of power thereby conferred as a power to 'make laws for the governing peace, order, and good government of the colony'; secondly, by the superior authority of imperial legislation extending to the colony. In other words, an enactment of a colonial legislature may be treated, even by the courts of the colony, as of no effect either because it is beyond the competence of the legislature to enact, or because, though within the competence of that legislature, it is repugnant to an imperial statute which applies to the colony. These two limitations to the effectiveness of colonial enactments must now be considered in detail.

The power to make laws for the 'peace, order, and good (r) Colo. government of the colony' confines colonial legislation to nial legisthe territorial limits of the colony. Colonial legislatures are $\begin{gathered}\text { must not } \\ \text { be extra- }\end{gathered}$ 'local and territorial legislatures' not merely in the sense in territorial. which every legislature is practically limited by the impossibility of making its legislation effective in alien jurisdictions, but in the sense that even within their own jurisdiction the municipal courts of a colony treat its extra-territorial legislation as a nullity ${ }^{1}$. An English court treats every Act of Parliament, whatever its seope, as valid; the rules limiting its application to England, to the United Kingdom, or to

secutive months of a session, withont tho leave of tho house to which he belongs (ss. 12, 25 of No. 2 of 1885-6). This rulo has been adopted in the Australian Commonwealth (cc. 20,38 of the Constitution, 63 \& 64 Vict, c. 12, s. 9).

' Cf. Harrison Moore on 'The Sourecs of the Laws of the Colonies' in Journal of Soc. of Comp. Leg., Aug. 1900. 
Сн. IV. British territory ${ }^{1}$, are mere prima facie rules of interpretation; only foreign courts can disregard (in virtue of international principles) the enactment of a sovereign law-making body, on the ground that it professes to be in force where the law-maker cannot enforce it. But a colonial court does not hesitate to disregard colonial acts, if it considers that they are ultra vires because extra-territorial. Thus, in 1879 , the Supreme Court of New Zealand held that the Foreign Offenders Apprehension Act, I863, of that colony, which authorizes the deportation of persons charged with indictable misdemeanours in other colonies, was beyond the competence of the New Zealand legislature, for it involved detention on the high seas, which the legislature could not authorize, as it could legislate only for peace, order, and good government within the limits of the colony ${ }^{2}$.

While this is the general limitation set to the powers of colonial legislatures, imperial Acts have in exceptional cases conferred an extended power of legislation. Sometimes the imperial Act authorizes a colonial legislature to make laws on a specified subject with extra-territorial operation ${ }^{3}$; sometimes an act of the colonial legislature is given (usually by Order in Council, authorized by imperial statute) the force of law throughout British dominions ${ }^{4}$.

Questions might be raised as to whether, apart from imperial statutes extending to the colony, there are not restrictions on the power of a colonial legislature to enact within territorial limits what laws it pleases. It might be contended that there are some subjects of internal legislation which, though clearly not extra-territorial, are yet so far matters of imperial concern that a colonial legislature has no power to deal with them ${ }^{5}$. Previous to Io \& II Vict. c. $8_{3}$, colonial legislation for the naturalization of aliens was sometimes so

${ }^{1}$ See Reg. v. Jameson [1896], 2 Q. B. 425, per Lord Russell, L.C.J., at p. 430, and Ilbert, op. cit., pp. 406-8.

${ }_{2}$ In re Gleich, Ollivier Bell and Fitzgerald's N. Z. Reports, S. C, p. 39.

3 e. g. Merchant Shipping Act, 1894 , ss. $478,736$.

4 e.g. 28 \& 29 Vict. c. 64 .

${ }^{5}$ Cf. Harrison Moore, op. cit. 
regarded. Finance and shipping are other subjects whieh Cir. IV. have raised this difficulty; the former because it used to be supposed that imperial fiscal policy was of paramount obligation, the latter because it threatened to overstep territorial limits. But a broader view of the powers of colonial selfgovernment combined with the conferment of special powers of legislation have probably met, or might be made to meet, all the cases that are likely to arise. Were a colonial legislature to raise the question by passing a Bill dealing with such subjects, even if the Bill were not vetoed or disallowed the practical difficulty would probably be met by an overriding imperial statute. It is easy, however, to imagine a ease which would raise difficult questions of theory; e.g. would it be beyond the powers of a colonial legislature to enact that within the limits of the colony the subjects of a foreign power with whom this country was at war should not be treated as alien enemies?

The second condition to be fulfilled by every colonial law (2) Colobefore it can have any effective operation is that it should not nial legisbe 'repugnant to the laws of England.' In most cases this must not condition is left to be understood, but in the instruments of nant. constitution of some of the colonies ${ }^{1}$ it is expressly laid down. The meaning of 'repugnancy' has been much discussed; the view which finally prevailed is embodied in 'an Act to remove doubts as to the validity of colonial laws,' known as the Colonial Laws Validity Act, $1865^{2}$.

This view is that a colonial law is void for repugnancy Moaning only if it conflicts with an 'Act of Parliament extending to of 'repugthe colony,' i.e. an Act by which Parliament intends to bind the colony. A colonial legislature has therefore full power to alter what is sometimes termed the 'common law of the colony'-an expression which in 'settled' colonies includes the whole law of England, statute law as well as common

1 e. g. New Zealand. See the proviso at tho end of s. 53 of 15 \& 16 Vict.

c. 72. Cf. $5 \& 6$ Vict. c. 76 , s. 29 , and 13 \& 14 Vict. c. 59 , s. I4.

${ }^{2} 28$ \& 29 Vict. c. 63 . Tho $\Lambda$ ct is set out in full in $\Lambda$ ppendix V. 
Cr. IV. law, so far as applicable to the colony at the date of settlement ${ }^{1}$. It is not, therefore, a complete statement to say that a colonial legislature 'may make laws opposed to the English common law ${ }^{2}$ ', for it may also make laws opposed to an English statute which, in the absence of such colonial legislation, would be in operation in the colony, not because made applicable to the colony, but merely as part of its 'common law.' For instance, the Caroline Statutes of Distribution, governing the descent on intestacy of personal property, operate in the Australian colonies ${ }^{3}$ save so far as they may be varied by colonial Acts.

In practice the conflict between colonial and imperial law, on the ground of the former's repugnancy to the latter, rarely arises ${ }^{4}$, because where it is threatened either the colonial Bill is disallowed, or, if the imperial Government is willing to make the colonial law effective, they procure for it the sanction of an imperial Act.

Powers of legislatures of selfgoverning colonies to make changes in their constitution.
The powers of internal legislation which have been described include, with certain exceptions now to be noted, the power of constitutional change. Professor Dicey has expressed this feature by saying that colonial parliaments, though non-sovereign, are commonly both legislative and ' constituent' assemblies ${ }^{5}$. 'This power to vary the provisions of the instruments of constitution by which they are created appears in different forms and subject to different conditions in the early statutes setting up the various colonial legislatures ${ }^{6}$. But these detailed regulations are largely

' See p. 5, supra.

${ }^{2}$ Dicey, Law of the Constitution, p. Tor.

3 All the Australian colonies are 'settled.' See Cooper v. Stuart, L. R. I4 A. C. 286, especially at p. 29 I.

' For a case where it was discussed, see Robinson v. Reynolds, Macassey's N.Z. Reports, p. 562, where a New Zealand court laid it down that a statute of the General Assembly is not void for repugnancy to the law of Eugland unless it is opposed to some Act of the imperial Parliament made expressly binding upon and applicable to the colony.

5 Dicey, L.C. p. I04. Cf. Bryce's Studies in History and Jurisprudence, ii. p. 199.

See Appendix VIII : 'Early Constitutional History of the Australian Colonies.' 
superseded by an enactment of general application con- Cr. IV. tained in sect. 5 of the Colonial Laws Validity Act, I $865^{1}:-$

'Every colonial legislature shall have, and be deemed at all times to have had, full power within its jurisdiction to establish Courts of Judicature, and to abolish and reconstitute the same, and to alter the constitution thereof, and to make provision for the administration of justice therein; and every representative legislature' (i.e. by sect. I, every colonial legislature which comprises a legislative body of which one-half are elected by the inhabitants of the colony) 'shall in respect of the Colony have, and be deemed at all times to have had, full power to make laws respecting the constitution, powers, and procelure of such legislature, provided that such laws shall have been passed in such manner and form as may from time to time be required by any Act of Parliament, letters patent, order in council, or colonial law for the time being in force in the said Colony.'

The proviso appears to mean that if any Act, imperial or Powers of colonial, requires Bills varying the constitution of a colonial constitulegislature to be specially reserved for the Royal Assent, or to change in be passed by any particular majority, such requirements must tralian still be observed; but that if no such requirements exist, a Colonies. colonial legislature may alter its constitution by ordinary enactment.

Thus, the New South Wales legislature may 'alter the provisions or laws for the time being in force ... concerning the Legislative Couneil,' provided that every such Bill 'shall be reserved for the signification of Her Majesty's pleasure thereon, and a copy of such Bill shall be laid before both houses of the imperial Parliament for the period of thirty days at the least before Her Majesty's pleasure thereon shall be signified ${ }^{2}$ '

$128 \& 29$ Vict. c. 63.

${ }^{2}$ S. 36 of the Constitutional $\Lambda$ ct, scheduled to $18 \&$ i9 Vict. c. 54 . The 
Сн. IV. The Victorian legislature may modify the constitution of either house (or the official salaries and pensions included in Schedule D of the Constitution Act) only by Bill which (I) passes its second and third readings in both houses by an absolute majority in each, and (2) is then reserved for the royal pleasure ${ }^{1}$.

This requirement of absolute majorities for any Bill effecting a change in the legislature also obtains in Western Australia ${ }^{2}$.

In South Australia, Bills which alter the constitution of legislative council or house of assembly must be passed by an absolute majority in both houses and reserved ${ }^{3}$.

In Queensland, the constitution of the legislative assembly may be varied by ordinary Bill; but any alteration in the legislative council must be by a Bill which passes its second and third readings in both houses by a two-thirds majority, and the Bill must be reserved and laid on the table of the House of Commons for thirty days ${ }^{4}$.

In Tasmania, Newfoundland, the Cape Colony, and Natal there appear to be no special statutory conditions for Bills involving constitutional change.

Power of constitutional change in New Zealand ;

New Zealand stands in a curious position. The Constitution Act of $185^{2}{ }^{5}$ requires the reservation of Bills altering its provisions concerning elections, the salary of the governor, provincial councils, and certain other matters. But section 2 of 20 \& 2I Vict. c. 53 empowers the General Assembly of New Zealand 'to alter, suspend, or repeal all or any of the provisions of the said Act' (viz. the Constitution of $185^{2}$ ) 'except such as are hereinafter specified'; and then follows a list of the provisions of the Constitution Act which the

requirement of unusual majorities in this section and in s. 15 has been repealed by a New South Wales statute of 1857 (20 Vict. No. Io).

1 S. 60 of the Constitution Act, scheduled to I8 \& I9 Vict. c. 55 .

${ }^{2}$ S. 73 of the Constitution, scheduled to $53 \& 54$ Vict. c. 26.

${ }^{3}$ S. 34 of South Australia Act No. 2 of $1855-6$.

${ }^{4}$ Constitution Act of $1867,3^{I}$ Vict. No. $3^{8}$ of the colony, ss. 9 and ro.

5 I 5 \& 16 Vict. c. 72. 
New Zealand Legislature cannot alter. Included in these Сн. IV. unalterable provisions are the section declaring the New Zealand Parliament to be bi-cameral ', and the sections prescribing the form of oath or affirmation to be taken by members ${ }^{2}$. The question therefore arises, whether the Colonial Laws Validity Act (which is subsequent in date to $20 \mathrm{\&}$ 2 I Vict. e. 53) gives to the New Zealand Legislature the power to amend its constitution in those particulars which the Act of 1857 declares to be beyond its power to change. It is submitted that it does not. The Colonial Laws Validity Act is an Act to remove doubts, not to make changes, and it follows that there are some things in the New Zealand Constitution of $185^{2}$ which the General Assembly cannot alter at all; others which it can alter only by reserved Bill; and yet others which it may alter by ordinary enactment.

The two federations of Canada and Australia are also in unaffected by section 5 of the Colonial Laws Validity Act, although both are self-governing colonies in the sense of $5^{8} \& 59$ Viet. c. $34^{3}$. The powers of the Dominion Parliament to amend the constitution are limited to changes of small importance: it can only (I) vary the quorum for the senate ${ }^{4}$; (2) regulate electoral machinery ${ }^{5}$; (3) vary the franchise ${ }^{6}$; (4) vary provisions to meet the case of the Speaker's absence ${ }^{7}$; $(5)$ increase the number of members, but only if the proportionate representation of the provinecs is preserved ${ }^{8}$; (6) fix judicial salaries ${ }^{9}$; (7) establish a general court of appeal and additional courts ${ }^{10} ;(8)$ alter the salary of the governor-general ${ }^{11}$; and (9) establish a new province in any territories of the dominion not ineluded in an existing province ${ }^{12}$. In fact, the provincial legislatures have within their limits a greater power of constitutional ehange than the

1.S. 32 of $15 \&$ I 6 Vict. c. 72 .

3 Cf. 63 \& 64 Vict. c. 2, s. 8.

${ }^{2}$ Ss. 46 and 47 .

30 Vict. c. 3 , s. 35 ; but not for the House of Commons, s. 48.

S. 40.

${ }^{8}$ S. 52 .

6 S. 4 r.

S. 100.

${ }^{7}$ S. 47 .

"S. IO

${ }^{12} 34$ Vict. c. 28, s. 2.

10 S. IOI. 
Cr. IV. Dominion Parliament. To alter the senate, to alter the seat of government, to abolish either house, to alter the proportionate representation of the provinces, an imperial Act would be necessary. On the other hand, the provincial legislatures can amend the constitution of the province, except as regards the office of lieutenant-governor ${ }^{1}$.

and in the Clause 128 of the constitution of the Australian CommonAustralian Common. wealth. wealth ${ }^{2}$ prescribes the mode in which that constitution can be altered. Any Bill which provides for such alteration must first pass in each house by an absolute majority, and must secondly be submitted, not less than two nor more than six months afterwards, to the electors in each state who are qualified to vote for the house of representatives. Its fate then depends on the result of this referendum.

It will be noticed that the power of constitutional change conferred on representative legislatures by section 5 of the Colonial Laws Validity Act is a power to make laws respecting the constitution, powers, and procedure of the legislature. An earlier part of the same section confers not only on every representative legislature, but on all colonial legislatures, a retrospective power to alter the constitution of the colonial can judiciary. But a power to vary the constitution of the colonial colonial executive is neither explicitly created nor explicitly tures vary limited or taken away. Such an omission is characteristic the constitution of the
executive? from the administration in British instruments of constituof the prominence given to the legislature as distinguished tion. They set forth the representative system explicitly and in detail, but they leave the position and powers of responsible ministers to be determined by constitutional usage. It is obvious that there are some matters of administration, e.g. the position of the governor, which, though arising wholly within the colony, are beyond the power of the colonial legislature to affect; but it is not altogether easy to draw the line which bounds the right of the colonial legislature to affect the exercise of the prerogative of the Crown 
within the colony. For instance, could such a legislature Cir. IV. enact that a colonial bishopric should be filled only by colonialborn clergymen? Or that the governor should exercise his power of pardon only in accordance with a popular plebiseite? Such hypothetical enactments cannot be said to be extraterritorial, and there can be no question that the imperial Parliament could make them.

In nearly all the self-governing colonies laws purport to be The posimade, not by the governor, but by the Crown 1, 'by and with tion of the advice and consent' of the two houses. But in New in colonial Zealand Acts are expressed to be made 'by the General tion. Assembly of New Zealand in Parliament assembled,' and Newfoundland statutes are passed 'by the Governor, the - Legislative Conncil, and the House of Assembly in legislative session convened.'

A Bill after it has passed the two houses is, it is true, presented to the governor of the colony, but it is so presented for His Majesty's assent. Three courses are then open to the governor :-

(I) He may assent to the Bill in His Majesty's name. In The this case the Bill (unless it contains a suspending clause re- governor's quiring the special confirmation of the Crown) beeomes law from the date of his signification of assent, or from the date of commencement specified in the Bill itself. It is the duty, however, of the governor to transmit to the Colonial Office a copy of the Act in order that the Crown may have an opportunity of exercising its power of disallowanee. The instruments of constitution of some colonies prescribe that this power of disallowance, if exercised at all, must be exercised within two years ${ }^{2}$. The Crown's disallowance takes

1 The enactments of somo of the Canadian provinces, however (like tho ordinanees of colonies without representativo assemblies), aro not profaced with tho namo of the King. In Nova Scotia statutes aro oxpressed to bo marlo by the lieutenant-governor, council, and assombly; and in New Brunswick, Prince Edward Island, and North-West Territories by tho lieutenant-governor and assembly. On the other hand, in Ontario, Quelee, Manitoba, and British Columbia the regular form is adopted.

2 e. g. Canada (3o Vict. c. 3, s. 57). 
Сн. IV. the form of an Order in Council, and is signified by the governor in speech or message to the legislature, or by other official notification, and the Act becomes void from that time forward.

The governor's

(2) He may withhold His Majesty's assent, i. e. veto the veto. Bill in His Majesty's name. The Bill is then as absolutely lost as would be a Bill of the imperial Parliament, were the Crown to exercise its obsolete power of veto over imperial legislation. The governor's veto is exercised, like his power of reservation, in accordance with instructions from home. These instructions may be in general terms or in reference to a particular measure; they may owe their origin to the forethought and experience of the Colonial Office, or they may be in answer to a request of the governor for advice in view of apprehended damage to imperial interests. Failing such instructions, the governor of a self-governing colony now exercises his veto only on the advice of his ministers and not according to his own personal discretion '.

Reserva- (3) He may reserve the Bill for the signification of His tion. Majesty's pleasure. Some Bills are so reserved in consequence of provisions in instruments of constitution requiring reservation for measures of their class ${ }^{2}$; others in consequence of a provision in the Bill itself; others in consequence of the governor's instructions from home '. A reserved Bill is of no effect until the Crown assents to it. Such assent is by Order in Council, and must be signified by the governor, in a manner similar to that in which the Crown's disallowance is signified, within two years from the day on which the Bill was presented to the governor for His Majesty's assent.

Reservation and disallowance contrasted.
It will be noticed that a reserved Bill to which the Crown fails to assent within two years never has any legislative force at all, whereas the disallowance of a measure to which the governor has assented only operates' to deprive of further

1 For a full discussion of the question, see chap. vi.

2 See above, pp. 73, 74 .

${ }^{3}$ Cf. par. Io of Old Instructions, and par. 8 of Present Instructions in Appendix IV [New South Wales (iii) and (iv)]. 
effect an Act which is actually in force until disallowed. Crr. IV. The two years' interval within which the Crown's assent to reserved Bills must be signified is still invariably retained: it is a survival from the old rule which was enacted for the Australian colonies by the still existing imperial Act of $1842^{1}$. The period seems absurdly long in the case of Canada, though not too long sixty years ago for communication with Australia. On the other hand, the requirement that the Crown's prerogative of disallowance should be exercised within two years only appears in the instruments of constitution of some of the self-governing colonies; in others, no limit of time is imposed; while clause 59 of the Constitution of the Australian Commonwealth ${ }^{2}$ provides that the Crown may disallow any law within one year from the governor-general's assent.

The extent to which imperial eontrol over colonial legis- Practical lation, by way of governor's veto or subsequent disallow- limits on ance, is in fact exercised, is discussed elsewhere ${ }^{3}$. On the one control hand, so long as points of contact between imperial and colonial colonial interests continue to arise, it is impossible for the legislaCrown's veto on colonial legislation to become a dead letter: on the other hand, not only has a constitutional understanding grown up as to the cases in which the wishes of colonial legislatures may be overruled, but these cases are becoming steadily more rare. Two illustrations, separated by just half a century, will show the narrowing of the field for imperial interference. In 1849, an Act of the legislature of New Brunswick granting a bounty for the cultivation of hemp within the colony was made the text of a dispatch from the Colonial Office to the lieutenant-governor, direeting him in future to veto such measures ${ }^{4}$. On the other hand, the British Investors in New Zealand Government Securities Act, I $900^{5}$, contains a provision (section 5) which rums :-

$5 \& 6$ Vict. c. 76.

$263 \& 64$ Vict. c. 12, s. 9.

${ }^{3}$ Chap. vi ; cf. Dicey, L. C. p. III ; Todd's Parl. Govt. in British Colonies, pp. 130 seq.

1 Grey on Colonial Policy, vol. i. p. 279.

- 64 Vict. No. 9 of New Zealand. 

sembly is passed which in the opinion of the imperial Government in any way injuriously affects the rights or remedies of the holders of New Zealand Government securities, or alters the terms of the contract under which such securities were created or issued, then that Act may properly be disallowed by Her Majesty.'

Earl Grey would indeed have been astonished at a colonial legislature attempting to prescribe in what circumstances the Crown might exercise its power of disallowance. The truth is that the home authorities will now interfere only in two cases: (I) where, in the opinion of the law officers of the Crown, a colonial enactment is ultra vires; and (2) where, if a colonial enactment stands, imperial interests would be directly prejudiced. The section from the New Zealand statute above quoted was inserted in return for an imperial Act, authorizing English trustees to invest in colonial securities ${ }^{1}$, in order to preserve intact the rights of investors in those securities; but the provision is none the less significant because it suggests the view that colonial consent is desirable where imperial disallowance cannot be justified on either of these two grounds.

Federa- The federal constitutions within the empire-the Dominion tions within the of Canada and the Commonwealth of Australia ${ }^{2}$-require in empire. some respects separate treatment. These two federations are necessarily alike in exhibiting the essential characteristic of federalism, viz. the distribution of powers between the federal government and its constituent states; but if this inevitable point of resemblance is set aside, the contrasts between these two federations are more remarkable than the similarities. Before attempting a comparison, each federation will be considered separately.

1 The Colonial Stock Act, Igoo (63 \& 64 Vict. c. 62), s. 2.

${ }^{2}$ In addition to these, the Leeward Islands form a federation of non-self-governing colonies; see below, chap. v, p. 97. The federation of South Africa was provided for, but never carried out under an Act of 1877 . 
In I 866, the colonies of Canada (consisting then of Upper Cr. IV. and Lower Canada), New Brunswick, and Nova Seotia agreed to a federal union; and this agreement, which was carried into effect by the imperial Act known as the British North Canada. America Act, $1867^{1}$, nuited these colonies into one colony, under the name of 'the Dominion of Canada,' with four provinees, Upper Canada beeoming the provinee of Ontario, and Lower Canada the province of Quebec.

Provision was made for subsequently ineluding Newfoundland, Prince Edward Island, British Columbia, Rupert's Land, and the North-Western Territory. Prinee Edward Island and British Columbia joined almost immediately, and became separate provinces. Newfoundland has not joined. Out of Rupert's Land and the North-Western Territory have been formed the provinee of Manitoba, and various districts which together form the North-Western Territories ${ }^{2}$.

The Act expressly declares that the executive power and the command of the naval and military forces are vested in the Crown, and the executive government is to be carried on through a governor-general on behalf of and in the name of the Queen, but with the aid and advice of a Privy Council.

The Privy Council consists not only of the cabinet ministers in office but also of ex-cabinet ministers, who remain honorary members of it. The Cabinet, in fact, is a committee of the Privy Council, and powers given to the Governor-General in Council are exereised by the governor-general acting with the advice of his cabinet ministers.

The legislative power in the Dominion of Canada is given to a Parliament, which is required to meet annually, and consists of two houses, a Senate and a House of Commons.

The senators are nominated by the governor-general for life, but must be selected from residents in the different

$30 \& 31$ Vict. c. 3 .

2 All British possessions in North $A$ merica, otler than Newfoundland, were annexed to Canada by Order in Council of July 31, I880, Stat. R. \& 0 . Rev. vol. vïi, 1. 408. 
Cr. IV. provinces, so that Ontario and Quebec shall be each repre-

Parliament of Canada. sented by twenty-four senators; and in Quebec one senator must reside in each electoral division, while the maritime provinces, i.e. Nova Scotia, New Brunswick, and Prince Edward Island, are represented by twenty-four senators, ten for Nova Scotia, ten for New Brunswick, and four for Prince Edward Island.

The number of senators to represent any new provinces depends upon the terms of admission, which are settled by an address of the houses of the Parliament of Canada, approved by the Crown, and carried into effect by order of the Sovereign in Council. But the maximum of senators cannot, unless upon the admission of Newfoundland, be increased above seventy-two, except by the admission of extraordinary members. On the recommendation of the governor-general the Crown may add either three or six extraordinary members to the Senate, but they must represent equally Ontario, Quebec, and the maritime provinces.

The House of Commons is elected by the people in electoral districts specified in the Act, and unalterable by the Parliament of Canada. The franchise and the qualification of the members and the mode of election were made the same as before 1867 , but can be settled from time to time by the Parliament of Canada. The franchise is a wide one.

The representation of the four provinces is to be readjusted by the Parliament of Canada after the completion of each decennial census, on the principle that Quebec is to have sixty-five members, and the other provinces a number proportionate to their population, and that the number of members of each province is not to be reduced unless its proportion of population is reduced by one-twentieth ${ }^{1}$.

The result of these provisions is that each province has a fixed number of representatives in the Senate, but that the representation in the House of Commons is in proportion to

1 This readjustment seems to imply a corresponding power to alter the electoral districts. 
population, the principle being thus similar to that of the $\mathrm{C}_{\mathrm{H}}$ IV. United States Congress. Each House of Commons is to last five years, unless sooner dissolved by the governor-general.

The Aet of 1867 (ss. 9I-5) distributes the powers between the Parliament of Canada and the provineial legislatures ${ }^{1}$, but reserves to the former all powers not expressly given to the latter, the reverse of the provision in the United States constitution, and (as we shall see) in that of the Australian Commonwealth.

In the Canadian provinees the exeeutive power is vested in Governa lieutenant-governor, appointed by the Governor-General provinces in Couneil (i.e. by the central exeeutive) and paid out of the ${ }^{\text {in Canada. }}$ funds of the central Government. He is aided by an executive couneil, consisting of certain ministers who are appointed by him, but who in effect must have the confidence of the legislative body. The number of these ministers is fixed in the case of Ontario and Quebee by the British North Ameriea Aet of 1867 , and in the ease of Nova Seotia and New Brunswiek by the previous law, but is in every ease alterable by the provincial legislature.

The provineial legislature consists; of the lieutenantgovernor and house of eleeted representatives, called 'the legislative assembly, to which in Quebec and Nova Scotia there is added a second house, ealled 'the legislative couneil,' consisting of members appointed for life by the lieutenantgovernor, one of whom in Quebee is to represent each of the twenty-four eleetoral divisions of Quebee existing in I867. The form of the enacting elause, as we have seen ${ }^{2}$, varies.

In Ontario and Quebee the electoral divisions for the house of assembly were fixed by the $\Lambda$ et of 1867 , but made alterable by the provineial legislature, with a restrietion in the case of Quebec as to the majority by whieh the Aet is to be passed. The franehise, the qualifications for members, and the method of election to the house of assembly, until

1 Set out in App. III, with an abstract of cases illustrating the effest of the sections.

2 Supra, P. 77, note I. 
Сน. IV. altered by the provincial legislature in each case, were to continue the same as in the former colony of Canada; but the legislative assembly was to continue only for four years, unless sooner dissolved.

The constitution of each of the provincial legislatures of Nova Scotia and New Brunswick was left as before the Act, until altered by that legislature.

Each provincial legislature, as respects taxes, money Bills, and the assent to Bills, was placed in the same position as the Parliament of Canada except in one important point. The lieutenant-governor and not the Crown forms part of the legislature, and the instructions of the lieutenant-governor, subject to which he is to act, are given by the governorgeneral, on the advice of his Canadian ministers, and not by a Secretary of State on behalf of the King.

The disallowance also of a Bill passed by the provincial legislature is by the governor-general, and such a Bill, if reserved, is reserved for the signification of the pleasure of the governor-general. The governor-general acts according to the advice of the Canadian ministers, and consequently the Home Government has no direct control over legislation by the provincial legislatures in Canada.

Australian Proposals for the constitution of a central authority for Federation. the Australian colonies were made by Lord Grey as long ago as 1856 , but the proposals then made were premature, and met with no general support. The establishment of the Dominion Parliament of Canada in 1867 , suggested to Sir Henry Parkes the expediency of following the Canadian example, but the movement for federation still stagnated for several years. An Australian conference, summoned at the instance of Sir Henry Parkes in 1883 , led to the passing by the imperial Parliament of the Federal Council of Australasia Act, I $885^{1}$; which anthorized a federation of the Australasian colonies, by creating a council of two members, subsequently increased to five members, from each colony. This council 
was given power to legislate on various subjects, such as the Cr. IV. relations of the colonies with the Paeifie Islands, fisheries in Australasian waters beyond territorial limits, the enforeement of eivil and eriminal process beyond the limits of each colony, the extradition of offenders, and the eustody of offenders on board ships belonging to the colonial Governments beyond territorial limits. The council could also legislate on any matters referred to it by Order of the Queen in Couneil, made on the request of the colonial legislatures. The legislature of any two or more colonies might also refer to the council for legislation, questions of defence, quarantine, patents, copyrights, bills of exchange, recognition of marriage and divoree, naturalization, joint stock companies, and other matters of general Australasian interest. But the legislation on a subject so referred, was to extend only to the colonies referring it, and such other colonies as might afterwards adopt the legislation.

The council met on various occasions, but the several colonies were not fully represented at the different meetings; the legislation passed was not extensive, and the seheme cannot be considered to have been a suceess ${ }^{1}$.

Negotiations for a closer union between the different Australian colonies still frent on, and a convention which met at Sydney in 189 I produced the draft of a Commonwealth Bill, which became the basis of all subsequent diseussions. In 1895 the premiers of the Australian colonies agreed to bring forward enabling Bills in their several parliaments for providing a convention of delegates which should be instrueted and empowered to frame a constitution. This constitution, after consideration by the several parliaments, and reeonsideration by the convention, was finally ito be submitted to the people of the several states under a general referendum. In these circumstances, the Bill to eonstitute the Commonwealth of Australia was formally framed by the eonvention which sat in Adelaide in I 897, and in Sydney and Melbourne in

' Sec particulars in Colonial Offico List under 'Victoria.' 
Cr. IV. I 898 , was amended by the conference of premiers at Melbourne - in 1899 , was adopted on a referendum to the electors of the colonies of New South Wales, Victoria, Queensland, South Australia, and Tasmania, in I899, and was in that year transmitted to England on addresses to the Queen from both houses of parliament in each of the five colonies, praying that it might be passed into law by the imperial Parliament.

The

Commonwealth of Australia (Constitution) Act.

The Bill thus sent to England was introduced by Mr. Chamberlain as a Bill to the imperial Parliament on May I4, I900', and received the Royal Assent as an imperial Act on July 9 of the same year ${ }^{2}$.

The Act vests the legislative power of the commonwealth in a federal parliament, consisting of the Crown, the senate, and the house of representatives.

The senate consists of senators for each state, directly chosen by the people of the state. There are six.senators for each of the original states, that is to say, for each of the states which are part of the commonwealth at its establishment. These numbers may be altered by federal legislation, but equal representation of the several original states is to be maintained, and no original state is to have less than six senators. The senators hold office for six years.

The house of representatives is composed of members directly chosen by the people of the commonwealth, and the number of these members is to be, as nearly as practicable, twice the number of the senators. The number of members to be chosen in each state at the first election is fixed by the Act, but may be altered for a subsequent election, according to an ingenious system of calculation based on the principle of making the number of members chosen in the several states bear proportion to the respective numbers of their people.

1 Mr. Chamberlain's speech on the introduction of the Bill gives a succinct account of the circumstances which led to the preparation and passing of the measure; Hansard (Fourth Series), vol. Ixxxiii. p. ${ }_{4} 6$.

${ }^{2}$ Under the title of the Commonwealth of Australia (Constitution) Act $\left(6_{3} \& 6_{4}\right.$ Vict. c. I2). 
The house of representatives sits for three years unless Cr. IV. sooner dissolved. The qualifications of electors of senators and of members of the house of representatives are to be the same. Elaborate provision is made for the contingency of disagreement between the senate and the house of representatives. If, after certain other stages they fail to agree on a proposed law, there is to be a joint sitting of the two houses, and the law may be passed by an absolute majority of the total number of the members of both houses.

The legislative powers of the parliament extend to the making of laws for the peace, order, and good government of the commonwealth, with respect to a long list of specified subjects. The several states retain their powers of legislation; but if the law of a state is inconsistent with the law of the commonwealth, the latter is to prevail, and the former is, to the extent of the inconsistency, to be invalid.

The governor-general is the Sovereign's representative, and is advised by a federal executive council. As representative of the Crown, he has the command-in-chief of the naval and military forces of the commonwealth.

There is a federal supreme court, which is to be called ' the High Court of Australia,' and consists of a chief justice and so many other justices, not less than two, as the parliament prescribes. Justices of the high court are appointed by the Governor-General in Council, and are not removable except by the Governor-General in Council on an address from both houses of parliament in the same session, praying for such removal on the ground of proved misbehaviour or incapacity.

Provisions are made for the relations of the commonwcalth to the several states in mattcrs of finance and trade, and in particular for the imposition of uniform dutics of customs throughout the commonwealth within two years after its establishment.

The constitutions of the several states and the powers of their parliaments remain as before, except as expressly altered 
Сн. IV. by or under the constitution of the commonwealth. There will continue to be governors of the several states appointed by the King, not lieuteuant-governors as in the Dominion of Canada.

Provision is made for the admission of new states, and for the seat of Government, which is eventually to be in the state of New South Wales.

Any alteration of the constitution requires an absolute majority of the two houses of the federal parliament, and involves a referendum.

The Bill as passed by the imperial Parliament was on almost all points identical with the draft Bill sent to England from Australia. Provision was made for the admission of Western Australia as an original state, and certain words which had raised doubts as to the applicability of the Colonial Laws Validity Act were struck out. But the only question on which any substantial difference of opinion arose between the imperial Government and the colonial representatives related to the question of appeals from the new federal high court.

The provision on this subject which appeared in the draft Bill as sent to England, and which became widely known as 'Article 74,' was the result of a compromise between those who wished to retain the existing right of appeal to the Queen in Council and those who wished to abolish it altogether, and ran as follows :-

Appenls No appeal shall be permitted to the Queen in Council in any 'from the matter involving the interpretation of this Constitution or of the Constitution of a State, unless the public interests of some part Australia. of Her Majesty's Dominions, other than the Commonwealth or a State, are involied.

Except as provided in this section, this Constitution shall not impair any right which the Queen may be pleased to exercise, by virtue of Her Royal Prerogative, to grant special leave of appeal from the High Court to Iler Majesty in Council. But the Parliament may make laws limiting the matters in which such leare may be asked.

This change was objected to by Her Majesty's Govern- 
ment, and the Bill as introduced into the House of Commons Cir. IV. provided that-

Notwithstanding anything in the Constitution set forth in the Sehedule to this Aet, the prerogative of Her Majesty to grant special leave to appeal to Her Majesty in Conneil may be exercised with respect to any judgement or order of the Iligh Court of the Commonwealth, or of the Supreme Court of any State.

Ifter long negotiations and several attempts to effect $\Lambda$ iticle $7 \%$. an arrangement between divergent views, Article 74 was eventually settled as follows:-

No appeal shall be permitted to the Queen in Council from a decision of the Iligh Court upon any question howsoever arising as to the limits inter se of the Constitutional powers of the Commonwealth and those of any State or States, or as to the limits inter se of the Constitutional powers of any two or more States, unless the High Court shall certify that the question is one which ought to be determined by IIer Majesty in Couneil.

The High Court may so certify if satisfied that for any speeial reason the certificate should be granted, and thereupon an appeal shall lie to Her Majesty in Council on the question without further leave.

Except as provided in this section, this Constitution shall not impair any right whieh the Queen may be pleased to exercise by virtue of IIer Royal Prerogative to grant special leave of appeal from the Iligh Court to Ifer Majesty in Council. The Parliament may make laws limiting the matters in which such leave may be asked, but proposed laws containing any such limitation shall be reserved by the Governor-General for IIer Majesty's pleasure.

The chief constitutional difference between the federations The of Canada and Australia arises from the circumstance that in federaAustralia the federal legislature has only those powers which Canada are expressly conferred upon it, whereas in Canada it is the Australia provincial legislatures which are limited to the exercise of conpowers specifically delegated to them, the Dominion Parliament being left with the residue. Connected with this is the distinction that the constituent parts of the federation in Canada are 'provinces': whatever their status before I 867 they are not self-groverning colonies after it; while the six 'states' of which the Commonwealth of Australia is composed are and remain self-governing colonies, while at the same time combining in federation to form a larger whole. Each of: 
Сн. IV. the Australian 'states' retains its colonial governor, who continues to be appointed by and responsible to the Crown, whereas in Canada the provincial licutenant-governors are, as we have seen, appointed and dismissed ${ }^{1}$ by, and liable as regards their assent to provincial legislation to be overruled by, the Governor-General in Council.

While, however, in the matter of distribution of legislative power the constitution of Australia approximates more nearly to the United States constitution than does the constitution of Canada, in neither of the colonial federations does the resemblance with the American scheme extend much beyond what is common to all federal forms of government. Apart from the fundamental distinction, already pointed out, which is based on our conception of 'responsible government,' the points of difference are numerous and important. Thus in the United States the governor of each state is elected by the people of the state; and the federal government has no control over the governor or legislature of a state, or over the internal administration of the state, except for the purpose of enforcing the laws of the federation, governing the militia, and suppressing insurrection. In fact, apart from the division of powers which is necessary in every federation and the fixed proportion of the number of senators from each province, it is difficult to specify any point of resemblance between the Government of Canada and that of the United States which is not also a point of resemblance between the former and the Government of the United Kingdom. One other point of resemblance with the United States must be conceded in the case of Australia-viz. the leaving to constituent states of the residue of legislative power-but apart from this the points of resemblance between the federal constitutions of Australia and the United States are equally few.

1 Cf. the case of Mr. Letellier, lientenant-governor of Quebcc, who was dismissed by Lord Dufferiu, the governor-general, upon the advico of Dominion ministers, although his continuance in office was desired by a majority of the Quebec legislature. 


\section{CHAPTER V}

\section{COLONIES NOT SELF-GOVERNING}

THE colonies which are without responsible government, Crr. V. and therefore not self-governing ${ }^{1}$, may be divided into two classes, those which have and those which have not repre- classes of sentative institutions. non-self governing

The latter may be divided into those whieh have a council colonies: and those which have no council. (I) those with,

The second class are Crown colonies strictly so called, (2) those though that term is frequently applied also to the first representclass. tutions.

The eolonies of both classes have certain general points of Rolation resemblanee. Their connexion with the United Kingdom is to the much closer than that of the self-governing colonies, and has Governmore of a subordinate, and less of a federative, character. A mueh larger portion of the local government is carried on under the direetion of the Home Government.

The constitutional authority of the imperial Parliament is greater, as it is the practice for Parliament to legislate for a Crown colony of either class in cases where it would not legislate for a self-governing eolony, or at any rate would not do so without previously consulting the colony 2 .

But it would be contrary to constitutional practice that

1 For a list of these, see $\Lambda$ pp. II.

2 Thus the Colonial Courts of $\Lambda$ dmiralty $\Lambda$ et, 1890 ( 53 \& 54 Vict. c. 27 ), was applied to almost all the Crown colonies without consulting them, whereas it was expressly exeluded from applying to New South Wales and Vietoria, because those colonies had not assented. See also the Mail Ships $\Lambda$ ct, 1891 (54 \& 55 Vict. c. 31 ). 
Cr. v. Parliament should tax the colony, or should alter its constitution, except with its own consent?

The legis- The legislature of the colony is, when acting within its a Crown colony. powers, supreme. But the control exercisable by the Home Government over the legislation of the colony is very much greater, because the governor acts directly upon the instructions of the Home Government, and is not tied by the advice of ministers who are responsible to, and dependent on the support of, a majority of the local legislature. In Crown colonies proper, and in some of the other colonies that are not self-governing, the governor has the sole initiative in legislation.

The Even where there is a representative assembly the executive ministers are appointed by the governor independently of that assembly, and do not depend for holding office upon retaining the confidence of the assembly.

As the executive ministers in all colonies, self-governing as well as others, are appointed by the governor and hold office during his pleasure, they are legally all in the same position. But constitutionally, in the self-governing colonies the ministers can only hold office if they retain the confidence of the representative legislative body, while in the other colonies the ministers are independent of the legislative body, even though it may be a representative assembly. The change from the latter to the former position of ministers requires, as before observed, no legislative alteration, but merely instructions to the governor who is responsible for the selection of his ministers ${ }^{2}$. But the practical and constitutional effect

1 This view was not always accepted. In $188_{3} 8$ the constitution of Lower Canada was suspended. The proposal of Lord Melbourne's Government to suspend the Jamaica constitution in 1839 without consulting the colony was opposed by Sir R. Peel, and led to the resignation of the Government. See Sir Robert Peel's speech on the Jamaica Government Bill, Peel's Speeches, iii. 623. The old constitution of Jamaica

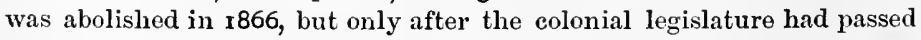
an Act for the purpose; and the same course was adopted in the case of other West Indian islands. If an emergency arose the ordinary rulo might again be disregarded.

${ }^{2}$ See Merivale, p. 636 ; C. O. R. 57 . 
of this change is immense. The colony is converted into Си. $\mathrm{V}$. a self-governing colony.

Where the ministers are not responsible to a local legislative body, the governor is an absolute, not a constitutional, sovereign; he governs and does not merely reign; it is his duty to regulate, and he has power to regulate, the local administration; and he is responsible for that administration to the Home Government. In a self-governing colony these duties, powers, and responsibilities are vested in the ministers. When the colony is not self-governing the governor, although he may be bound to act on the advice of his ministers, can change those ministers without regard to the views of the local legislative body. But he is necessarily subject to the practical limitations that government can only be carried on, at any rate where an English population is concerned, with the general assent of at least a large portion of the population, and that government upon English principles cannot be carried on against strong public opinion of the locality.

As the governor is the nominee of the Home Government, this additional power and responsibility of the governor in a colony which is not self-governing means additional power and responsibility on the part of the Home Government. That Government has thus a responsibility for good local administration, which is upon a colony becoming self-governing transferred to the colonial ministers.

In a Crown colony, within the strictest sense of the term, the Home Government-that is to say, either the King by a document countersigned by the Secretary of State, or the Secretary of State in his name-nominates the judges, appoints or approves the appointment of all public officers, approves of the budget, controls the public works and the loans and general finance of the colony, requires legislation for certain objects, and interferes more or less in the colonial legislation and in the details of colonial administration ${ }^{1}$.

In a colony which, though not self-governing, has a repre- 
Cн. V. sentative assembly, the control is less direct. It may be that

Relations

of the representative body to the local government.
Conflict between legislature and executive in Malta. the governor has not the sole right of initiating legislation, and that the budget has to be accepted by the assembly. But the Home Government may require the governor to dismiss ministers for refusing to initiate legislation desired by the Home Government, or for submitting a budget disapproved by that Government, and may require him to veto an Act of which the Home Government disapprove.

In colonies of this class conflicts of opinion and authority are very apt to arise between the governor or his nominee ministers and the representative assembly. These conflicts have led on the one side to the establishment of a selfgoverning colony where there was an active white population, either without, or with only a few, coloured voters, and on the other side to the abolition of the representative assembly where a tropical climate enervates the activity of the white population, or where coloured voters are numerous ${ }^{1}$.

The Cape and Natal have an active white population and a very large coloured population; but the members of the latter have not in practice the franchise, and therefore do not constitute a political force in the representative legislature, though they seriously complicate the questions to be dealt with. These colonies have been made self-governing, though a large part, perhaps the majority, of the white population are not of British descent, while little if any security has been taken for the proper treatment of the coloured population.

In Malta the majority of the legislative council consists of persons who are elected on a franchise which excludes many persons, or represents special interests, such as the ecclesiastics or nobles. It has been found necessary to use the legislative power of the Crown to override opposition by this council to measures which the Home Government considered to be required in the interests of the majority of the population;

1 Several West Indian islands have recently surrendered their representative legislatures. 
and this power has been used even to impose a tax for the cir. $\mathrm{V}$. expenses of sanitary works ${ }^{1}$.

The differences between the Crown colonies proper are broadly as follows:

In some the Crown has retained the power of legislating Legisla. for the colony, whether by Order in Coumeil or by Letters tive power Patent. In others this power has been abandoned ${ }^{2}$. of the

The King's Bench decided in $1774^{3}$ that where the Crown granted a representative legislature to a conquered colony, without reserving the legislative power, the original power of the Crown to legislate was surrendered. And that power is not considered to have revived although the representative legislature has been abolished.

In a settled colony that power never arose except under the British Settlements Acts ${ }^{4}$.

In one or two cases (e.g. the Straits Settlements) an imperial Act gives general power to the Queen in Council to legislate for the colony ${ }^{5}$.

The legislative power of the Crown is but rarely exereised, exeept in Crown colonies within the strictest sense of that term. The exereise of it is usually for the purpose of dealing with what, in the case of a colony with responsible government, would be eonsidered an imperial subjeet, or for purpose of coinage, which may be considered also an imperial subject. It might also be used in a fortress like Gibraltar or Malta for aiding the defence of the fortress. Where there is a representative legislative body the exercise of the Crown's legislative power is more unusual than where there is only a nominee couneil or no couneil at all.

In such a case, however, it may be cxercised (as mentioned above in the ease of Malta) in the interests of the majority of

1 Parl. P., 1899, No. 287 ; and O. in C. of July 14, 1899.

2 See the list of such colonies in $\Lambda$ pp. II.

${ }^{3}$ Campiell v. IIall, 20 St. Tr. 239.

' 5o \& 5 I Vict. c. 54, and thro onactments repealed by that $\Lambda$ ct.

\& 29 \& 30 Vict. c. I15. Cp. also Jamaica, 29 \& 30 Vict. c. 12; and Grenada, $39 \& 40$ Vict. c. 47 . 
Сн. V. the population, as against certain powerful interests, who control the legislative body.

The power is used as a means of inducing a legislative body to pass a particular measure. In the case of Malta the threat of its use did not avail.

Folms of constitutions in Crown eolonies.

The colonies with representative institutions differ: in some cases the legislature consists of two chambers, in others of only one.

In some West Indian islands the old English model of a colonial constitution still survives, that is to say, a legislature of the two Houses, one elected by the people, the other nominated by the Crown. The latter often forms the executive council of the governor, and sometimes sits as a court of appeal.

This form of the constitution was, in the early part of the eighteenth century, considered to be so much a matter of course that it was granted almost immediately after the conquest of a conquered country; but it was found unsuitable to the circumstances of a colony where a large number of the voters consisted of negroes or half-castes, who, after the abolition of slavery, had acquired political rights, but not the political genius necessary for representative institutions. For this reason it has been abolished in some of the West Indian colonies ${ }^{1}$. The abolition was effected by a law passed by the legislature, with a request to the Crown to create a new constitution or (as in Honduras) with an addition of an enactment of the new constitution.

In other colonies the legislature consists of one chamber, some only of the members being elected by the people, and others nominated by the Crown.

In some of these colonies the number of the elective members is fixed below that of the nominee members, in other cases it is fixed so as to give the elective members the majority. In the latter case the governor, and consequently

1 e.g. Jamaica, Grenada, St. Vincent, Tobago, Honduras. In I884, however, Jamaica again obtained a representative legislature. 

Colony.

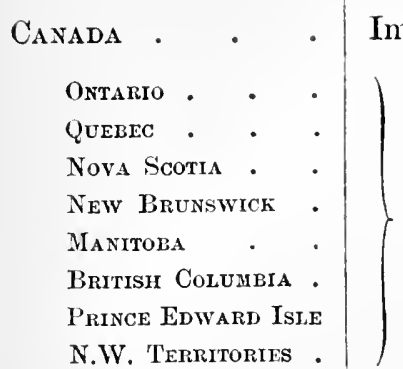
Instrument of Constitution.

Newfounda nd

New South Wales .

VICTORIA

South Australia .

Queensland . .

Western Australia

Tasmania . .

New Zealand . .

The Cape Colony .

Natal

Commonwealth of Australia
Imperial Act, 30 Vict. c. 3 [1867] .

Note. -The provinces of the Canadian Federation are not self-governing colonies, and these details are here inserted only for convenience of reference. On the other hand, the states constituting the Australian Commonwealth are, no less than the Commonwealth itself, self-governing colonies. See sehedule to $5^{8} \& 59$ Vict. c. 34 ; cf. $6_{3} \& 6_{4}$ Vict. c. I2, s. 8 .

Senate of 8I mem

(No Upper

Legislative Council c Legislative Council c

(Upper House abo

(Upper House abo

(Upper House a

Commission to Governor of Mareh2, $183^{2}$; cf. Letters Patent of March 28, I876, St. R. \& O. Rev. vol. iii. p. 57I

Colonial Bill scheduled to Imperial Act, I8 \& 19 Vict. c. 54

Colonial Bill scheduled to Imperial Act, I8 \& 19 Vict. c. 55

Colonial Act, No. 2 of $1855^{-6}$, passed in virtue of I3 \& I4 Vict. c. 59

O. in C. of June 6, I859, confirmed by 24 \& 25 Vict. c. $44, \S 3$, and amended by Colonial Act, $3^{\text {I Vict. No. } 3^{8}}$

Colonial Bill scheduled to Imperial Act, $53 \& 54$ Vict. c. 26

Colonial Act, I8 Vict. No. I7, passed in virtue of $I_{3} \&$ I4 Vict. c. 59

Imperial Act, 15 \& 16 Vict. c. 72 [1852]

Colonial Ordinance, confirmed by $\mathrm{O}$. in $\mathrm{C}$. of Mareh II, I853, and amended by Colonial Act, No. I of 1872

Royal Charter of July 15, 1856, amended by Colonial Act, No. I4 of 1893

Imperial Act, 63 \& 64 Vict. c. 12 [1900]
Legislative Coun ceeding ${ }_{5} 5$ (

Legislative Counc than 2I (now Legislative Counc Legislative Counc Legislative Counc Legislative Coun Legislative Coun Legislative Coun Legislative Coun

Legislative Counc Senate of $3^{6}$ (6 fo 


\section{G COLONIES}

pper House.

Nominated for life

se-B. N.A. Act, sect. 69)

- Nominated for life

- Nominated for lise

d by Colonial Aet, 54 Viet. c. 9)

d by Colonial Aet, 39 Vict. e. 28)

Upper House)

hed by Colonial Act, 56 Vict.)

Upper House)

not ex- Nominated for life (5)

not less Nominated for life 48 . Elected for 6 years

24 . Elected for 9 years

42 . Nominated for life

30 - Elected for 6 years

I9 Elected for 6 years

45 - Nominated for 7 yrs.

23 - Elected for 7 years

I2 . Nominated for IO years

istate) Elected for 6 years

\section{I.ouer IIouse.}

$\{$ House of Commons of 213 members

Elected for

• 5 years.

Legislative Assembly of 94 . $\quad 4$ years.

Legislative Assembly of 74 . 5 years.

Legislative Assembly of $3^{8} \quad$. $\quad$. 5 years.

Legislative Assembly of 46 . . 4 yrs. 2 mths.

Legislative Assembly of 40 . . 4 years.

Legislative Assembly of $3^{8} \quad . \quad 4$ years.

Legislative Assembly of 30 . . 4 years.

Legislative Assembly of $3^{\mathrm{I}} \quad \cdot \quad 4$ years.

House of Assembly of $3^{6}$. 4 years.

Legislative Assembly of 125 . 3 years.

Legislative Assembly of $95 \quad$. 3 years.

House of Assembly of 54 . 3 years.

Legislatrve Assembly of $72 \quad$. 3 years.

Legislative Assembly of $5^{\circ} \quad$. 3 years.

House of Assembly of $3^{8}$. $\quad$. 3 years.

Iouse of Representatives of $74 \quad 3$ years. House of Assembly of 95 • 5 years.

Legislative Assembly of $39 \quad$ - 4 years.

Ilouse of Representatives of $75 \quad 3$ years. 

the Home Gorernment, have obviously much less power than Crr. V. they have where the nominee members are in the majority.

Even where the council consists wholly of nominee members, a difference arises, as in some cases all the members of the council are officials, in other cases they are partly official and partly unofficial. In some instances the number of official members, in others that of unofficial members, is the larger ${ }^{\mathbf{1}}$.

Where the Home Government insists on a measure being passed by the legislative council, the official members are bound to vote for it. A measure is sometimes so insisted on, either for imperial purposes or to give effect to a treaty ${ }^{2}$, or for local purposes, where the measure is for the general benefit, but is objected to by the influential classes from which the members of the council are drawn.

Where there is no representative body, the initiation of all legislation, including that for taxes, rests with the governor, and even where there is a representative body, the general rule is that no money shall be appropriated, and no tax imposed, except on the recommendation of the governor. This rule is strictly in accordance with that of the United Kingdom, but has a different effect in consequence of the governor acting on his own motion, and not on the advice of persons having the confidence of the representative body.

The West Indian colonies have shown a disposition to unite Federaso as to reduce the expenses of government. tion in $\operatorname{th} \theta$ West

Under an imperial Act of $186 \mathrm{I}^{3}$ the colonies of Antigua, Indies. St. Kitts, Nevis, Dominica, Montserrat, and the Virgin Islands were combined into a single colony under the name of ' the Leeward Islands,' with six presidencies.

There are a governor and executive and legislative council for the whole colony, and a president and executive and legislative council for each presidency. The Act fixes the powers to be exereised by the federal legislature.

${ }_{1}$ For the composition of the various councils, sce Parl. P., 1889, No. 70, and 1890, No. 194.

2 e. g. the treaty with France of 1854 respecting mail ships.

${ }^{3} 34$ \& 35 Vict. c. 107. 
Cн. v. The Islands of Grenada, St. Lucia, and St. Vincent are under one governor-in-chief, the Governor of the Windward Islands, but there is no central executive or legislative council : each island has its own council, and a resident administrator who acts as the deputy of the governor.

Another of the Windward Islands, Tobago, has been annexed to Trinidad under the imperial Act of $1887^{1}$.

On the other hand the West African colonies, after being under a single governor for some years, were again divided into separate colonies. And the Seychelles have been severed from Mauritius ${ }^{2}$.

In some of the West Indian colonies the Council, with the Governor, acts as a court of appeal.

I $50 \& 5$ I Vict. c. 44 .

Stat. R. and 0., I897, p. 676. 


\section{CHAPTER VI}

\section{COLONIAL GOVERNORS}

Is every British possession the Goveruor is appointed by Cur. VI. the Crown, and is the representative of the Crown in the possession; but there the resemblance between the governors of different classes of British possessions ceases. The position Appoint. ment and and powers of the governor of a colony differ from those of the governor of a British possession which is not a colony, and the position and powers of the governor of a self-governing colony differ from those of the governor of a Crown colony. The present chapter will treat of colonial governors, that is to say, of governors of colonies, whether self-governing or not.

Every governor holds during the pleasure of the King, but the usual term of office is six years. Formerly each governor was appointed and commissioned by Letters Patent, under the Great Seal of the United Kingdom; but sinee 1875 the practice has been to ereate the office of governor in each colony by Letters Patent, and then to make each appointment to the office by commission under the Royal Sign Manual, aud to give to the governor so appointed instructions in a uniform shape under the Royal Sign Manual. The commission is countersigned by a Secretary of State. The instruetions are often approved by Order in Couneil ${ }^{1}$, and are all issued under the Royal Sign Manual with the 'signet' attaehed by the Secretary of State, but without his counter-signature; subsequent special instructions are given to the governor through the Secretary of State. The Letters Patent, commission,

\footnotetext{
1 Sce Stat. R. and O., I895, pp. 739 ser.
} 
Cr. VI. appointment, and instructions, are commonly, for the sake of brevity, referred to as 'the governor's commission ".'

Besides these instructions the Secretary of State issues from time to time circulars which are practically instructions to the governors, such as those relating to martial law in I867, and to pardons in 1877 . Some of these are, with other rules, put together into what are known as 'the Colonial Regulations,' for the information and guidance of governors and all officers appointed by the Home Government ${ }^{2}$.

Dignitics The constitutional rule is that the Crown is the sole founand honours. tain of honour in the British Empire. A colonial governor has no power to confer any dignity or honour except by express warrant from the Crown under the sign manual, and the grant of lonours by the King is no interference with the rights of a colonial legislature.

The Governor-General of Canada (and not the provincial Lientenant-Governor) has the right to appoint King's counsel for all courts in the dominion, but a provincial legislature can confer on the Lieutenant-Governor of the province power to appoint King's counsel for courts within the province, because it can determine by what officers the Crown, or in other words the executive government of the province, is to be represented in its courts of law or elsewhere ${ }^{3}$.

Military It will be observed that the governor's commission contains command. only a provision requiring all military officers to obey him, and does not confer on him military command. Even though the constitution gives him, as it in some cases does, the title of captain-general or commander-in-chief, he does not thereby obtain military command unless it is given him by

1 The forms now in use are printed in Appendix IV. See also Stat. R. and O. Rev., vol. viii, Appendix of Prerogative Orders.

2 These are printed in the annual Colonial Office List, and referred to herein as 'C. O. R.'

${ }^{3}$ Attorney-General for Dominion of Canada v. Attomey-General for Province of Ontario, L. R. [1898] A. C. 247. This overrules the decision of the Supreme Court of Canada in Lenoir v. Ritchie (quoted in Todd, Col. Govt., and ed., p. $33^{6}$ ), which was to the contrary effect, and was based on the ground that the Queen was not part of the provincial legislature. 
special appointment from the Crown. He is not, therefore, $\mathrm{CH}_{\mathrm{r}} \mathrm{VI}$. invested with the command of any part of the regular forces, that is to say, any part of the British regular forces which is in the colony ${ }^{1}$. He is not therefore entitled, even though he is the military officer of highest rank in the colony, to take the immediate direetion of any military operations, or, exeept in the case of urgent necessity, to communieate officially with subordinate military offieers without the concurrence of the officer in command of the regular forces in the eolony.

If military operations are rendered necessary, either by invasion or assault of a foreign enemy or by domestic strife, the officer in chief command of that portion of the regular forces which is in the colony assumes the entire military authority, and is responsible for the details of military operations.

It is, however, for the governor to determine the objects with which, and the extent to which, the King's troops are to be employed, and to give general directions as to their distribution and employment.

The governor on the one hand, and the military officer on the other, are bound to eonsult together as to the matters within each other's province ${ }^{2}$.

In a colony where no portion of the regular forces is stationed, the military command of the colonial forees depends on the legislation of the colony.

As regards Canada, by s. I 5 of the British North America Act , the command-in-ehief of the land and naval militia, and of all naval and military forces, of and in Canada was declared to continue and be vested in the Queen. In accordance with that section, the Canadian Militia $\Lambda$ et of 1868 provides that ' the command-in-chief of the land and naval militia and of all naval and military forces of and in Canada is vested in the Queen, and shall be exereised and administered by Her

${ }^{1}$ C. O. R., ch. ii. s. 2. As to India, see above, ch. iii. p. 51 .

2 C. O.R. 12 A.

$30 \& 31$ Vict. c. 3 . 
Cr. VI. Majesty personally or by the governor as her representative.' But the commission of the governor does not give him more military power than that of any other governor.

In Canada, those matters which are of imperial direction, and concern the regular army and navy, are subject to the control of the Home Government, while those which concern the disposition and management of local forces are regulated by the local government ${ }^{1}$.

Statutory power of governor.

The imperial Acts relating to the constitution of the colonies give no general, as distinct from specific, powers to a governor, and are as a rule silent about his position and powers, except as regards his consent to legislation.

Thus the British North America Act ${ }^{2}$ is silent as to the powers of the Governor-General of Canada and the LieutenantGovernors of the provinces, except so far as it transfers to these officers statutory powers existing under other imperial or colonial Acts. The Act, like the Acts relating to the Australasian colonies, treats the governor as a well-known officer. The explanation of the silence of these Acts is that the powers of a governor depend primarily not upon the Acts, but upon his commission from the Crown and his position as representing the Crown in the colony, i.e. as the supreme executive of the colony.

Various Acts dealing with imperial subjects or otherwise applying to the colonies give specific powers to the governor, as in the case of extradition, territorial waters or merchant shipping.

Governor - The position of a colonial governor has been considered in not a viceroy. more than one case ${ }^{3}$ by the Judicial Committee of the Privy Council. The Judicial Committee have laid down that the governor cannot be considered as being a quasi-sovereign or viceroy, i.e. as having all the prerogatives of the Crown

1 Todd, Col. Govt. (2nd ed.), p. 377 .

2 30 \& 3 I Vict. c. 3 , ss. I2, 65 .

3 Cameron v. Kyte (1835), 3 State Trials, N.S. 6o7, see 6I6-8; Hill v. Bigge (184r), 4 State Trials, N. S. 723, see 731, 732 ; Musgrave v. Pulido (1879), L. R. 5 A. C. IO2, III. 
or having the whole sovereignty of the colony delegated to Cur. VI. him, unless it is expressly given him by the commission. Consequently, the powers of the governor must depend upon his commission in each case, and he is only an officer to act within the scope of his commission and to execute the powers which that commission expressly and impliedly gives him; and it has been further laid down that there exists in the case of a governor no such necessity, as Lord Stowell said might exist in the case of a naval commander, for the exercise of powers of sovereignty out of the ordinary and usual course.

The commission gives, it will be observed, very little express Power power. In a characteristically English way, it defines but given by little, and by authorizing the governor to do and execute all commisthings that belong to the office, incorporates the practice without stating it. This provision of the commission and the dependence of the powers of the governor upon his commission, give great elasticity. Practice and custom give more power in one colony and less in another, according to local circumstances; and thus in former days immediately after the conquest of a colony the governor was able to exercise powers which had been previously vested in the government superseded by the conquest.

The commission also can always be varied to meet local circumstances. It may confer on the governor, as it has in India, the whole prerogative of the Crown, even as regards dealings with foreign powers; or it may give him the chief command of the troops. On the other hand, it may restrict his powers if circumstances make it desirable to do so.

Notwithstanding legal decisions of the Judicial Committee as to the limitations on a governor's powers, there can be little doubt that a governor will always be held to have had all the power necessary for meeting any emergency which may have required him to take immediate action for the safety of the colony. If he acts in good faith, and, having regard to the circumstances, reasonably, he will be held harmless. In the 
Cr. VI. last resort the colonial legislature or the imperial Parliament will intervene to indemnify him ${ }^{1}$.

The Mr. Todd ${ }^{2}$ asserts this 'reserve power' of the governor in 'resernor's very wide terms. He says, 'Nevertheless there is a general power.' devolution to every colonial governor of so much of the authority of the Crown as may be necessary for the purpose of administering the government of the colony over which he is placed by the sovereign, whose office and authority he represents. . . The office of governor is as much a constituent of the constitution in every colony as is that of either of the other branches of the local legislature. A constitutional governor is not merely the source and warrant of all executive authority within his jurisdiction: he is also the pledge and safeguard against all abuse of power, by whomsoever it may be proposed or manifested.'

With respect to this 'reserve power' reference may be made to the Colonial Regulations ${ }^{3}$ and to the opinion of Willes, J., in delivering the judgement of the Exchequer Chamber, in Governor Eyre's case ${ }^{4}$. After referring to a charge of Tindal, C. J., as to the obligation of every citizen to endeavour to suppress a riot, the judge continued, 'This perilous duty, shared by the governor with all the Queen's subjects, whether civil or military, is in an especial degree incumbent upon him as being entrusted with the powers of government for preserving the lives and property of the people and the authority of the Crown, and if such duty exists as to tumultuous assemblies of a dangerous character, the duty and responsibility in case of open rebellion are heightened by the consideration that the existence of law itself is threatened by force of arms and a state of war against the Crown established for the time.'

The Jamaica legislature passed an Act of indemnity for Governor Eyre, which indemnified him against actions for damages brought in England. Phillips v. Eyre, L. R. 6 Q. B. I.

${ }_{2}^{2}$ Parliamentary Government in the British Colonies (2nd ed.), p. 36, a book of which much use has been made in this ehapter.

S. O.R. 34, 35 .

4 Phillips v. Eyre, L. R. 6 Q. B. I, at p. 16. Tindal's charge will be found in the Bristol Riots case, 3 St. Tr. N. S. I. 
This judgement had reference to a colony which was not $\mathrm{Cr}$. VI. self-governing. In a self-governing colony, the ministers are responsible to the colonial legislature for maintaining Detween the peace and good order of the colony, and it rests with them governors and not with the governor to take the steps neeessary for that governing purpose. The governor has thus in a self-governing colony colonies. less responsibility, and therefore in a sense less 'reserve power,' than he has in a colony where he is responsible to the Home Government for maintaining the peace and good order of the colony, has full liberty to choose his ministers and advisers, and appoint such officers as he thinks proper for the purpose, and cannot throw any part of the responsibility on the colonial legislature or local ministers or officers.

This is only one, though a very important, instanee of the wide distinction as regards position and power between the governor of a self-governing colony and the governor of any other colony, whether with or without a representative assembly.

An examination of colonial history during the past thirty or forty years shows that there has been a gradual change in the position of the governor; that in the self-governing colonies he has gradually become more of a constitutional sovereign and less of an actual governor. He 'reigns' more and 'governs' less. In other words, he acts less upon his personal opinion and more upon the advice of his ministers.

A colonial governor is under the control of the Crown, Acts as exercised throngh a Seeretary of State, and acts in two inperial capacities; namely, $(a)$ as an imperial officer, and $(\zeta)$ as a local offeer: officer.

Mr. Herman Merivale, for twelve years Under Secretary of State for the Colonies, thus states ${ }^{1}$ the position of a governor of a self-governing colony:- 'So far as regards the internal administration of his Government he is merely a constitutional sovereign, aeting through his advisers, interfering with 
Сн. Vr. their policy or their patronage, if at all, only as a friend and important councillor; but whenever a question is agitated touching the interests of the mother country, such for instance as the imposition of customs duties or the public defence, his functions as an independent officer are called at once into play; he must see that the mother country receives no detriment. In this duty he cannot count on aid from his advisers; they will consult the interests either of the colony or of their own popularity; he may often have to act in opposition to them, either by interposing his veto on enactments, or by referring those enactments for the decision of the Home Government; but for these purposes the constitution furnishes him with no public officers to assist him in counsel or execution, or to share his responsibility. The Home Government looks to him alone. . . In Crown colonies, he (the governor) is without check in executive affairs, and in the distribution of patronage, except such as may be administered from home. In the old representative colonies his acts are subject to the indirect check which may be given by the disapproval of the legislature, and the refusal of supplies, but to no direct interference. But under responsible government he becomes the image, in little, of a constitutional king. . . . Even in the domestic politics of the colony, his influence as a mediator between extreme parties, and controller of extreme resolutions, as an independent and dispassionate adviser, is far from inconsiderable, however cautiously it may be exercised. But the really onerous part of his duty consists in his watching that portion of colonial politics which touches on the connexion with the mother country. Here he has to reconcile, as well as he can, his double function as governor responsible to the Crown, and as a constitutional head of an executive controlled by his advisers. ... And this duty of peculiar nicety he must perform alone.'

Mr. Merivale's statement is still to a very large extent true, except as regards customs duties ${ }^{1}$. 
There is also an increasing tendency to regard the governor as a social head, and the patron of interests not connected with polities, rather than as concerned in the political Influeneo government.

of governor.

The influence which a governor enjoys as social head of the community is very great. $\mathrm{He}$ is able to present to the inhabitants of the colony wider views and higher aims in political matters than might otherwise prevail in a small community, namely, the views and aims of the best men in the British Empire as contrasted with those of men who are versed only in local politics. He can promote the interests of education, science, art, commerce, and humanity outside the domain of party politics ${ }^{1}$.

In quiet times and with certain governors this part of the governor's function is the most prominent. But even in quiet times the advice of a governor of ability and of experience in a wider sphere than that of the colony, is so valuable that he can greatly influence the government. And when a critical time comes, whether caused by the fierce conflicts of political parties or by outside circumstances, the governor, as the arbiter in those conflicts, or as representative of the Home Government, appears openly as a person of great political importance. It is with him in a small sphere as it is with the occupant of the throne of the United Kingdom in a larger sphere.

A governor's relations to his ministers and his duties vary Relations according as he acts as an imperial or local officer.

Thus, on March 26, 1862, the Secretary of State for the Colonies (the Duke of Newcastle) wrote as follows to the Governor of Queensland (Sir G. F. Bowen) :-

'The general principle by which the governor of a colony possessing responsible government is to be guided is this: that when imperial interests are concerned, he is to consider limself the guardian of those interests; but in matters of purely local

1 See as to this Lord Elgin in Wahrond's Life, pp. 124-8, and Todd (and ed.), pp. 8o9-12. 
Сн. VI. politics he is bound, except in extreme cases, to follow the advice of a ministry which appears to possess the confidence of the legislature. But extreme cases are those which cannot be reduced to any recognized principle, arising in circumstances which it is impossible or unwise to anticipate, and of which the full force can, in general, be estimated only by persons in immediate contact with them.'

The Duke of Newcastle, however, defined the 'extreme cases' referred to by him as 'such extreme and exceptional circumstances as would warrant a military or naval officer in taking some critical step against or beyond his orders. Like such an officer, the governor, who took so unusual a course in the absence of instructions from home, would not be necessarily wrong, but he would necessarily act at his own peril. If the question were one in which imperial interests were concerned, it would be for the Home Government to consider whether his exceptional measure had been right and prudent. If the question were one in which colonial interests were alone or principally concerned, he would also make himself, in a certain sense, responsible to the colonists, who might justify the course he had taken, and even prove their gratitude to him for taking it by supporting him against the ministers whose advice he had rejected, but who, on the other hand, if they perseveringly supported those ministers, might ultimately succeed in making it impossible for him to carry on the government, and thus, perhaps, necessitate his recall ${ }^{1}$ '

Rule 57 of the Colonial Regulations directs that:'In colonies possessing what is called responsible government, the governor is empowered by his instructions to appoint and remove members of the executive council, it being understood that councillors who have lost the confidence of the local legislatures will tender their resignation to the governor or discontinue the practical exercise of their functions in analogy with the usage prevailing in the United Kingdom.'

1 Parl. Papers, 1878, C. 21 73, p. 70. 
The instructions to the governor are as follows ${ }^{1}$ :-

'In the execution of the powers and authorities rested in him, the governor shall be guided by the advice of the executive council; but if in any case he shall see sufficient cause to dissent from the opinion of the said council, he may act in the exercise of his said powers and authorities in opposition to the opinion of the council, reporting the matter to us without delay, with the reasons for his so acting.

'In any such ease it shall be competent to any member of the said council to require that there be recorded upon the minutes of the council the grounds of any advice or opinion that he may give upon the question.'

This paragraph is now (with several others) omitted from the instructions to the Governor-General of Canada, not as being contrary to practice, but as unnecessary, because the constitutional practice is sufficient.

The governor is responsible solely to the Crown, and this responsibility creates a difference between his position as a eonstitutional sovereign and that of the sovereign in the United Kingdom.

His ministers, on the other hand, in a self-governing colony are, as in the United Kingdom, responsible to the colonial legislature, and especially to the popular chamber.

In matters for which the ministers are responsible, the governor should, as a rule, follow their advice, whether it is or is not in accordance with his own opinion.

The distinction between imperial matters and local matters is the same in the main as that between matters which are not and matters which are within the competence of the local legislature. It is in respect of matters of the latter class that colonial ministers are responsible to that legislature. In constitutional practice their advice must be followed in matters as to which they are, and need not be followed in matters as to which they are not, so responsible.

When the governor acts as an imperial officer, his duty

1 See $\Lambda$ ppendix IV, p. 230. 
Сн. VI. appears to be to consult his ministers before he acts, although he does not take their advice ${ }^{1}$.

But the obligation of the governor to act on the advice of the ministers in local matters is subject to the exceptions that he cannot be asked either to disobey the law or to aet contrary to his instructions from the Crown, and that he is at liberty to dismiss his ministers.

This power of dismissal is a reserve power which should only be used in extreme cases. The governor is a constitutional sovereign, and the duty of a constitutional sovereign is, as a rule, to take the advice of his ministers on local matters, even though he does not agree with it.

Power of pardon.
In exercising the Crown's prerogative of pardon, which is delegated to him by his instructions, the governor acts largely as an independent officer.

In regard to the pardon or reprieve of offenders, the present instructions ${ }^{2}$ to the Governor-Greneral of Canada require the governor-general to receive advice in capital cases from all, and in other cases from one, of his ministers; but ' in any case in which sueh pardon or reprieve might directly affect the interests of our empire, or of any country or place beyond the jurisdiction of the Government of our said Dominion,' he is, before deciding, to 'take those interests specially into his own personal consideration in conjunction with such advice as aforesaid.'

In the correspondence between Canada and the imperial Government prior to the issue of these instructions, it was understood that in all eases of a merely local nature the governor-general should act on the advice of his ministers. Before the issue of the new instructions, the governorgeneral had felt himself at liberty to disregard the advice of his ministers, and that with the approval of the Home Government.

As respects New South Wales ${ }^{3}$ and other colonies with

2 See Parl. Papers, 189o, vol. xlix, No. 194.

2 See App. IV, p. 2rg.

${ }^{3}$ See App. IV, p. 23I. 
responsible government, the present instructions are the same Cr. VI. as those for Canada quoted above.

The former instructions to the governor (e. g. of New South Wales in $1879^{1}$ ) required him to eonsult the executive eouneil, but to pardon or not 'according to his own deliberate judgement, whether the members of the exeentive couneil coneur therein or otherwise.'

The question as to the governor's porvers and duties with respect to pardons was much discussed in New South Wales, the result being that all applications for pardon are to be submitted to the governor through the intervention of a responsible minister, whose opinion is specified in writing upon the papers, thus leaving the responsibility for the exereise of the prerogative solely with the governor.

Lord Camarvon approved of this arrangement, and justified leaving the ultimate deeision to the governor on the ground that 'the effect upon neighbouring colonies, the empire generally, and foreign countries, of letting loose a lighly criminal or dangerous felon to reside in any part of the world .. . was a step which might elearly and not unreasonably give rise to complaints from without the colony.'

Similar questions have arisen also in Tasmania and in Canada, and particularly in reference to the wider question of a general amnesty or pardon. The porver to grant this is not given to a governor by his commission. But the governor, if so instrueted by the Home Government, ean, with the assent of his ministers, proclaim that no prosecution shall be instituted for certain offenees; and that has the same practical effect as an amnesty for them.

A question in which a governor may frequently lave to act Power of independently of, or even contrary to, the advice of his minis- dissolu. ters for the time being is that of the dissolution of the colonial legislature, or of that branch of it which is elected by the people.

The constitutional rule is that the exercise of, or the refusal

$$
{ }^{1} \text { S.O A.P. IV, P. } 227 .
$$




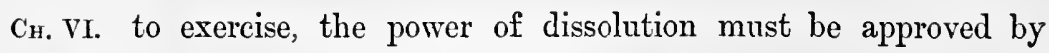
a minister of the Crown directly responsible to the popular branch of the legislature.

But, nevertheless, in granting or refusing a dissolution the governor should by no means be a passive instrument in the hands of his ministers. It is his duty to exercise his judgement on the advice that may be tendered to him.

In considering the matter, he should inform himself as to the probable result of a dissolution and new election, having regard to the state of opinion in the colony and the importance of the issue. Thus he should take into consideration whether the ministers against whom an adverse vote has been carried have not already appealed to the country; whether there are reasonable grounds for believing that the adverse vote would be reversed after a new election; under what circumstances the existing legislature was elected, and how long a period has elapsed since the last election; whether the majority against the ministers is such as to make it probable that a sufficiently strong Government can, if there is no dissolution, be formed by the Opposition; and whether there is any great question of public policy which the country ought to decide.

Various cases have arisen in the colonies in which a governor has refused to grant a dissolution upon the advice of his ministers: those ministers have thereupon resigned, and new ministers have been summoned who have carried on the government.

The principle to be gathered from these instances appears to be that, constitutionally, the discretion of the governor is in every case unfettered, and that he is not bound by any precedent. Each case must be decided according to the circumstances. It is his duty to consider the question of dissolution in reference solely to the general interests of the people and not to the interests of the party in power, which he is under no obligation to sustain. $\mathrm{He}$ is therefore justified in withholding a dissolution requested by his ministers, when he is of opinion 
that the object of the request is merely to strengthen their Crr. VI. party and not to ascertain the public sentiment upon any disputed question of public policy. If he believes that a strong administration ean be formed, commanding the confidence of the existing legislature, he is free, instead of granting a dissolution to his ministers, to aceept the alternative of their resignation and try if such an administration can be formed.

One very important matter in which the question arises Royal as to the obligation of a governor to take the advice of his assent ministers is the exercise of the prerogative of giving or with- allowance holding the assent of the Crown to an Act passed by the local tion. legislature.

The universal rule in colonies with representative legislatures, i.e. with legislatures consisting wholly or partly of elected representatives, is that when the legislature has passed a Bill the governor of the colony has power either to give or to withhold the King's assent, or to reserve the Bill for the signification of the King's pleasure.

Further, if he gives assent, he must send a copy to the Secretary of State for the Colonies, and, within two years afterwards, the King in Council can disallow the Bill ${ }^{1}$.

A reserved Bill which is not, within two years, assented to by the King in Council is, ipso facto, dropped.

In some cases the Bill contains a clause eommonly known as 'a suspending clause,' providing that the Bill shall not take effect until the Sovereign's assent has been signified in the colony, and some imperial Acts ${ }^{2}$ provide that an Act of the colonial legislature on some particular subject slall not be valid unless it contains such a suspending clause.

It will be observed that the withholding of assent, i.e. veto, is distinct from disallowance.

According to the old practice, the formal instructions by

1 See above, cls. iv, and, as regards the Australasian colonies, 5 \& 6 Vict. c. 76, ss. 3J-3; 7 \& 8 Vict. “ 74, s. 7, applied ly 13 \& 14 Vict. c. 59, ss. 32, 33; 18 \& 19 Viet. c. 54, s. 3; c. 55, s. 3. As to Cauadal, 3o \& 31 Virt. c. 3, ss. 55-7; as to other colonies, C. O. R.

"S..0 32 \& 33 Vict. थ. 11, s. 4; 48 \& 49 Vict. c. 7, s. 4 . 
(Mr. VI. Letters Patent, or under the Quecn's Sign Manual ${ }^{1}$, given to a governor in all colonies included provisions as to assenting to Bills, and expressly required him to reserve for the signification of the Queen's pleasure certain classes of Bills, unless they contain a suspending clause. As regards the Australasian colonies, the imperial Acts expressly authorized the Queen to give these instructions, and required the governor to comply with them ${ }^{2}$.

As regards Canada, the British North America Act, r $867^{3}$, provided (s. 55) that the governor should, in his discretion, subject to Her Majesty's instructions, assent to, or withhold assent to, or reserve, the Bill.

Considerable discussion has arisen in the case of the Australasian and Canadian colonies, as to whether the governor, in exercising these powers of assenting to, vetoing, or reserving Bills, ought to act under the advice of his colonial ministers.

The old doctrine was that the governor was bound to exercise his discretion upon his own responsibility as an imperial officer, unfettered by the advice of his ministers, but in accordance with the instructions of the Crown and after consultation with his ministers and (in case of assent) satisfying himself by legal advice that no legal objection exists to his assenting.

This is still the case in colonies not self-governing. But in self-governing colonies the doctrine is, especially in the case of Canada, that the governor must aet as a constitutional sovereign, that is to say, act on the advice of his ministers, unless he is prepared to dismiss or accept the resignation of those ministers, and to obtain other ministers to carry into effect his policy; and, as pointed out above, the dismissal or enforced resignation of ministers is a reserve power which should be rarely exercised. In fact, the frequent

${ }^{1}$ See App. IV, p. 226.

${ }^{2} 5$ \& 6 Vict. c. 76 , s. 40 , which was expressly applied to New South Wales by 18 \& 19 Vict. c. 54 , s. 3 , and to Victorian Bills by 18 \& 19 Vict. c. 55 , s. 3 .

s $30 \& 3$ I Vict. c. 3 . 
exercise of the powcr would practically make it impossible to Cr. V1. carry on the government.

In consequence of the acceptance of this doctrine, all provisions as to vetoing or reserving Bills have, since $\mathrm{I} 878$, been struck out of the formal instructions given under the Royal Sign Manual to the Governor-General of Canada, and any veto by the governor on imperial grounds must be given either under less formal directions from a Secretary of State, or on his own responsibility.

The practical result is that in Canada the power of the imperial Government is merely that of disallowing an Act which has been passed, and not that of vetoing a Bill before it becomes an Act.

In the case of the Australasian colonies, though royal instructions are still given to the governors to reserve certain classes of Bills for the signification of the King's pleasure, the number of these classes has been reduced so that they relate almost exclusively to imperial matters, and thus in all matters of local concern the governor is not bound by his instructions to interfere, and ought to be guided by the advice of his ministers as to the action he takes on any Bill.

But, as before pointed out, the governor is not the mere mouthpiece of ministers, he is responsible to the Crown for the proper administration of the colony; and thus even in a matter of purcly local concern, he may be able by discussion and persuasion to lead his ministers to advise or at least acquiesce in a course of action different from that which they had previously advised. Todd mentions a case in which the governor persuaded his ministers to countersign the royal assent to a Bill to which they had previonsly requested him to refuse the Queen's assent ${ }^{1}$.

A governor also is bound to protect imperial interests, and is not bound to act against the law, nor, therefore, to assent to a Bill which is ultra vires. In such a case he may have to refuse his assent, notwithstanding the advice of his

1 Todd (znd ed.), p. $66_{4}$. 
Сн. VI. ministers. He therefore stipulates for an assurance on proper authority that the Bill is within the competency of the legislature, and is not one which he is required by his instructions to reserve. This assurance is usually given by the colonial minister of justice, or attorney-general, or other law officer of the Crown in the colony, who reports to the governor whether any legal objection exists to the governor assenting to the Bill, or whether it is his duty as representative of the Crown to withhold assent to or to reserve the Bill ${ }^{1}$.

If the governor is not satisfied, and the matter is not one of purely local concern, he can take further counsel from the law officers in England through the Secretary of State. But if the question is one of purely local concern, it is not regular for him in a self-governing colony to take formal and official advice from any authority other than the law officers of the colony; and if he does so on a grave emergency he must personally take the risk, as he cannot shelter himself behind advice obtained from outside his ministry.

Disallow- Even where the governor has given the royal assent to an
ance by ance by Act of a colonial legislature, the Act can be disallowed by the King in Council.

The Act comes into operation at once (unless it contains a clause suspending its operation until the assent of the Crown is proclaimed, or some other act is done), but the governor transmits a copy to the Secretary of State for the Colonies, and the Act may be disallowed by the King in Council within two years after it is received.

Colonial Acts are, when necessary, referred by the Secretary of State to the law officers of the Crown for the purpose of ascertaining their legality; and if they relate to matters within the cognizance of another public department are referred to that department. Thus Acts relating to commercial questions are referred to the Board of Trade.

1 See Governor Manners Sutton's Dispatch, Parl. P., I867-8, vol. xlviii. p. 701. Lorl Dufferin's Dispatch, Parl. P., ז874, vol. xlv [C. 911$]$, p. 28. C. O. R., ch. iii. s. I, Parl. P., I878. 
In the case of the Australian Commonwealth and Canada, Сr. VI. the power of disallowance is statutory, as it was in the case of the Australasian colonies; but in the ease of other colonies the power rests on the charter, Order in Council, or other instrument regulating the constitution of the colony. Some of the charters in the eighteenth century required every law passed by the colonial legislature to be sent home for the approbation of the Crown, and the law, if not so approved was void, even though it purported to be enacted by the government and the assembly of the colony, and had been assented to by the governor. But this provision has disappeared except in Gibraltar ${ }^{1}$.

Acts passed by the legislature of a self-governing colony have from time to time been disallowed on the ground that they are ultra vires, or (as in the case of Acts relating to marriage with a deceased wife's sister) on the ground of general public policy.

Sometimes the Home Government cautions the colonial Government as to the exercise of powers conferred by an Aet, or as to the mode of administering an Act, and on receiving assurances in those respects from the colony does not disallow the Act.

In other cases objections to an Act are pointed out, and if they are removed by the colonial legislature within two years no disallowance takes place.

Not infrequently, also, the Home Government points out to the colonial Government, before a Bill proposed by them is passed into an Act, that the Bill will interfere with general imperial policy or interests, and suggests that it should be altered to remove those objections, or that its operation should be suspended until opportunity has been given to the Home Government to reconsider the objections in the light of the arguments of the colonial Government. The colonial legislature usually amends the Bill, and the necessity of disallowance is avoided ${ }^{2}$.

'Cp. the case of the Isle of Man, ch. ii.

2 For instance, a Copyright $\Lambda$ ct passed in 1889 by the Canadian 
Сн. VI. In the case of Canada in 1873 , an Act relating to oaths, and in 1878 one relating to merchant shipping were disallowed as being ultra vires ${ }^{1}$.

In 1874 an Act relating to copyright was disallowed on the ground that it was in conflict with imperial legislation. In 1875 the ministers were informed that if a Bill establishing a supreme court in Canada did not preserve to the Crown its right to hear the appeals of all British subjects who desired to appeal, the Bill would be disallowed, and consequently a saving clause was inserted in the Bill, and it received the royal assent.

In $1876-7$ a Queensland Act respecting Chinese immigration was reserved by the governor for the Queen's assent, and that assent was refused.

Within the last ten years there have been disallowed Acts of the Australasian colonies relating to merchant shipping (load line), to marriage with a deceased wife's sister, and to other matters, while a criminal code has been amended so as to avoid disallowance.

Where a colony is itself in the nature of a federation, the Crown may not have the same direct control over the legislation of the local legislature as it has over that of the central legislature.

InCanada. Thus in Canada the British North America Act, I867 ${ }^{2}$, placed the provinces, in relation to the dominion, in a position analogous to that in which colonies stand to the United Kingdom.

It provided (s. 9o) that the provisions of the Act respecting the assent to Bills, the disallowance of Acts, and the signif-

Parliament provided that it should not come into operation until proclaimed by the governor-general owing to objections by the Home Government, and that proclamation has never been made. See also the statement by Lord Knutsford, formerly Secretary of State for the Colonies, in the report of the House of Lords Committee on Copyright, Parl P., I898, vol. ix. No. 393, p. 23I, Q. 769. See also Todd (2nd ed.), pp. I57, 158.

${ }^{1}$ See return of Acts not assented to or disallowed, Parl. P., 1894, vol. xi. No. 196.

${ }^{2} 30 \& 31$ Vict. c. 3 . 
cation of pleasure on Bills reserved, should extend to provin- Си. VI. cial legislatures as if they were re-enacted for the respective provinees, with the substitution of the Lieutenant-Governor for the Governor, and of the Governor-General for the Queen, and of one year for two years.

The effect of this is (see ss. $55,56,57$, and 66) that the Lieutenant-Governor of a province assents to, vetoes, or reserves, a Bill by the advice of his provincial ministers. If a Bill is reserved, it is for the Governor-General to give assent to it by the advice of the dominion ministers.

Further, within twelve months after an Act has been assented to by the Lieutenant-Governor, the Governor-General ean disallow it.

A controversy arose between the Canadian ministers and the Secretary of State, whether in this disallowance the GovernorGeneral was to act on the advice of his ministers or independently.

The result may be said to be, that in the view of the Canadian ministers, the Governor-General must act solely on their advice; while the view of the Home Government was that the Governor-General, while bound to consult his ministers, need not precisely follow their advice, but had a right to act independently ${ }^{1}$.

The Canadian view can only apply to Acts of local concern. If a provincial Act contains sueh provisions as would, if they were contained in an Act of the Dominion Parliament, justify the Governor-General in acting as an imperial officer, and either refusing assent or reserving the Aet for the King's assent, even against the advice of his ministers ; or if the Home Government informed him that the Act would, if it were an Act of the Dominion Parliament, be disallowed, the GovernorGeneral ought to act as an imperial oflicer, and to disallow it even against the advice of his ministers.

Thus, if an Act like the reeent Act of British Columbia respecting the immigration of Japanese is contrary to treaties

' I'url. I', 1878-9, C. 2445, p. Io9. 
CII. VI. with Japan, it may become necessary for imperial reasons that the Act should be disallowed, although the Canadian ministers may be unable, having regard to public opinion in Canada, to advise the disallowance.

It is, however, worthy of note that the Crown has not quite the same power over the legislation of the local and subordinate legislature as it has over that of the central and superior legislature.

Todd $^{1}$ states the principles followed as respects the dis-. allowance of provincial Acts in Canada. He says that the Governor-General has in fact always acted on the advice of his ministers, and that disallowance has been freely exercised, but on the same principles as those observed by the Crown in relation to the colonies, namely, "that no mere calculation of political expediency or difference of opinion as to a colonial enactment would suffice to induce the Crown to veto the same, provided only it was within the legislative competency of the colony, and did not injuriously affect the interests of other parts of the empire.'

The British North America Act, 1867, guarantees to every province the right of local self-government in cases within the competency of the provincial authorities, and therefore does not contemplate any interference with the exclusive powers of the provincial legislatures, except in regard to Acts which are beyond ' provincial jurisdiction, or which assert a principle, or prefer a claim that might injuriously affect the interests of any portion of the dominion, or in the case of Acts which diminish rights of minorities,' as regards education, which are saved by s. 95 of the above Act.

The practice is for the minister of justice to report upon any provincial Acts which he considers open to objection, as being illegal, wholly or in part, or, in case of concurrent jurisdiction, as clashing with the dominion legislation, or as affecting the interests of the dominion generally.

No instructions have been given to the Lieutenant-Governors

1 Parl. Gov. Col. (and ed.), pp. 5ai-5. 
as respects the rescrvation of Bills, but they have in repeated Crr. VI. cases reserved for the consideration of the Governor-General Bills which appeared to them to contain doubtful or objectionable provisions.

The power of disallowance, though for the most part only exercised in cases where the Acts were ultra vires, has been sometimes invoked with respect to Acts 'whieh eontain provisions that were deemed to be contrary to sound principles of legislation, and therefore likely to prove injurious to the interests or welfare of the dominion.'

On the other hand, provincial Acts have in some cases not Acts utre been disallowed, though containing provisions regarded as necessariultra vires. They are left to take the chance of being declared ly disinvalid by the courts, or of being amended by the provineial legislature.

The cases before the Judicial Committec of the Privy Council show that this course has been not unfrequently adopted, as the question often has been whether a provincial Act was or was not intra vires, and this question has been argued on behalf of the attorney-general for the dominion on the one side and of the attorney-general for the province on the other. And the Judicial Committee has pointed out that though a provincial Act is void if repugnant to a dominion Act, which is within the powers of the Dominion Parliament, yet that repugnancy must be settled by the courts of law, and cannot be settled by the Dominion Parliament itself by a repeal of the provincial Act ${ }^{1}$.

It is also to be observed that the question of the validity of either a dominion or provincial Aet ean be referred by the Governor-General, or in the case of a provincial Act by the Lieutenant-Governor, to the Supreme Court of Canada or the province as the case may be; and the decision upon that reference is subject to an appeal to the King in Council, and is heard by the Judicial Committee, just like any other appeal

1 Attomey-Gencral for Ontario v. Attomey-General for the Dominion of Canada, L. R. $[1896], \Lambda$. C. 348 . 
Сн. VI. between private parties, and not as a non-judicial reference to the Committee. In the United States the question of the validity of legislation can only be tried in a case instituted for determining the rights of private parties.

The

governor in a nonselfgoverning colony.

In a colony which is not self-governing, the governor is not a constitutional sovereign, but the actual ruler. $\mathrm{He}$, and not his ministers, is responsible for the conduct of the local affairs of the colony. He is responsible to the Home Government, while his ministers are responsible to him, and not as in a self-governing colony to the local legislature. Where the local legislature comprises a representative assembly, the governor and his ministers must so act as to avoid, as far as possible, a deadlock by reason of the assembly refusing supplies or otherwise creating great difficulties in administration. But the ministers depend solely on the governor and not on the assembly for their continua: ce in office.

The governor in many such colonies has the sole initiative for legislation, and, subject to the control of the Home Government, appoints and dismisses the officers, and regulates the finance and the details of the government of the colony.

But, on the other hand, in the exercise of these powers he is, far more than the governor of a self-governing colony, under the control of the Home Government. The Colonial Office Rules and Regulations show how small is his freedom of action. While the most important officers are appointed by the Home Government, he has to obtain sanction for the appointment and dismissal of all but the humblest of the other officers, to report on the officers' conduct and efficiency, to submit all important questions to the Home Government, and obtain their sanction for new expenses and for the annual budget, and he must keep the Home Government informed on all the details of the administration. 


\section{CHAPTER VII}

\section{EXTRA-TERRITORIAL JURISDICTION}

'THE essence of political sovereignty is that it is legally Crr. VII. omnipotent within its own territory, but that it is legally powerless within the territory of another state'

The principle thus laid down has been recognized by the limited to Judicial Committee of the Privy Council ${ }^{2}$, and is also expressed in the maxim of the civil law, extra territorium ius dicenti impune haud paretur. The application of the principle differs as between civil and criminal proceedings.

With respect to civil proceedings the maxim actor sequitur Civiljurisfortm rei which is usually followed in countries governed by diction of Roman law, is not recognized by English law, and an English crurts. civil court has an almost unlimited jurisdiction to decide any matter which may be brought before it, without reference to the nationality or domicile of the litigants, or to the place where the cause of action arose.

In practice, however, English courts usually decline to exercise their civil jurisdiction where the person on whom or property on which the order of the court would operate is beyond the reach of the court, so that the court would only stultify itself by asserting jurisdiction, or where for any reason the court is of opinion that the proceedings might with more propriety have been taken elsewhere.

If, however, a ship comes within the jurisdiction of the High Court of England, the court will under its powers as an

1 Lewis, Foreign Jurisdiction, p. x. Seo also p. 8.

2 Papayanni v. Iiussian Steam Navig. Company (The Laconia), z Moore P'. C. (N. S.) I6r. 
Сн. VIr. Admiralty Court, arrest the ship so as to secure the execution of its orders.

The High Court in England can, upon cause shown, order the defendant in an action to be arrested and to give security not to leave England without leave of the court ${ }^{2}$. This provision was substituted for the old law of arrest upon mesne process, under which the first proceeding in every action was to arrest a defendant and require him to give security.

An instance will show more clearly the effect of the jurisdiction of Enghish courts.

A foreign ship manned by foreigners is driven by stress of weather into Falmouth; one seaman may sue for his wages in the Admiralty Division of the High Court; another may sue the mate in the King's Bench Division of the High Court for damages for an assault; a third, who has been mutinous and put in irons by the master, may first get his release by habeas corpus, and then bring an action in the King's Bench Division for false imprisonment.

In the admiralty proceedings the ship might be arrested by the court, and in the other proceedings the mate and master might be arrested and required to give security not to leave England:

The master, on the other hand, cannot, until he returns to his own country, take any proceedings to punish the seaman for his mutiny or disobedience of orders, nor even for a crime recognized as such by the laws of both countries, e.g. assault with intent to murder, if it was committed on board the ship beyond the three mile limit.

British ships, especially those which frequent American waters, have been often detained by actions brought, for the sake of extortion, against the ship or her officers on the eve of her departure, by low crimps or their attorneys in the name of some seaman of the ship. These actions usually take the form of actions for wages or assault or false imprisonment, 
and as there is usually some process similar to the Enghish Cr. VII. one by which either the ship or the master can be arrested and required to give security, the master, to avoid the detention of the ship, is obliged to yield.

Similar eases might arise in England, but in fact rarely do so, because of the practice of the court which is stated in the judgement of the Judicial Committee of the Privy Council ${ }^{1}$ as follows :-

' Their lordships are of opinion that in the case of a suit for wages by seamen for service on board a foreign vessel, the Court of Admiralty has jurisdiction, but that it will not exercise it without first giving notice to the consul of the nation to which the foreign vessel belongs, and that if the foreign consul by protest objects to the prosecution of the suit, the court will determine according to its diseretion judicially exereised, whether, having regard to the reasons advanced by the consul, and the answers to them offered on the part of the plaintiff, it is fit and proper that the suit should proceed or be stayed.'

In the case of a collision at sea between two ships, of which one is a British ship, and even in some cases where both are foreign ships, the British Court of Admiralty exercises jurisdiction if either ship has come within the territorial jurisdiction of the court.

The application, however, of the prineiples and maxims stated above to eivil proceedings belongs to what is called private international law, and is a matter of private rather than of public interest, as it mainly affeets the private interests of the persons concerned.

The applieation of the same principles and maxims to Criminal criminal proceedings raises questions of jurisdiction of more furisdicgeneral public importance, especially as the above-quoted English maxim as to sovereignty is only in part true. Owing to local. the increase of commeree and of eommunication in different countries the citizens of one country travel and reside to 
Cr. VII. a constantly increasing extent in the country of another, and the question of the criminal jurisdiction of a state over its subjects when outside its territory has become of considerable importance.

The civil law maxim has in respect of criminal proceedings its counterpart in English law, under which the jurisdiction to try for crime is purely local.

Under the old English law a man could only be placed on his trial for a crime by the finding of an indictment or accusation on oath against him by a grand jury, i. e. a jury of the freeholders of the county in which the crime was committed, and he was then tried upon the accusation by a petty jury of the inhabitants of the county before the court of assize for the county. And this, notwithstanding various modifications made in modern times, still remains the basis of the English criminal law.

Under that law an English criminal court has a local and not a personal jurisdiction; i.e. it has jurisdiction over offences committed within the limits of the locality where it has jurisdiction, but not over persons who have committed offences outside those limits. The procedure for trial by a grand jury and petty jury is based on this conception of criminal jurisdiction; and the exceptions which have been made to it have had to provide that the jurisdiction shall attach as if the offence had been committed within the local limits.

The Royal Commissions issued periodically under the Great Seal for constituting the courts of oyer and terminer and of gaol delivery (which together are commonly called the court of assize), direct the judges to inquire of and try in each county the offences committed there, and those courts can only try persons indicted by the grand jury of that county; and the grand jury of a county cannot at common law inquire into or indict a person for any offence committed out of the county. The statement of the proper county, the renue as it is termed, forms part of every indictment. 
Still less then was it possible for the court of assize to try Cr. VII. a person for an offence out of the British dominions. And the ancient expression still used in every indictment, though no longer essential to its validity, that the crime is committed against the peace of our Sovereign Lord the King, his Crown and dignity, is an expression of the doctrine that the offence must be committed within the King's dominions.

The trial, therefore, of British subjects in a British court for offences committed outside of the King's dominions is contrary to the procedure and practice, and to some extent to the theory, of English common law.

There are various objections in principle to the trial of Trial of persons for offences at a distance from the locality in which persons at the offences are alleged to have been committed. At the crime. locality the witnesses are usually on the spot, and although the prosecution, with public money at its back, may be able to obtain the presence of those witnesses at a distance from the spot, the person charged is much less able to do so.

Much also of English liberty is due to the fact that a person charged with an offence can only be tried by his neighbours, and when he has the sympathy of those neighbours he can act in politics and oppose the Crown, or the ministers of State, with much more boldness than if he could be tried amongst strangers.

Again, the removal of an accused person from the spot where the offence was committed may in itself be a very great hardship. Persons at a distance may often take a different view of the nature of the offence from those who are on the spot.

The sound principle is that crime should be tried by the authority which has jurisdiction at the spot where the crime was committed ${ }^{1}$.

1 See Lewis, For. Jur., pp. 29, 3о. Compare on these points Trevelyan's American Revolution, Pl. 116, 546. In Ireland, to take a Protestant from Antrim and try him by a Roman Catholic jury in Cork for an offenco which aroused religious feeling, or vice versa, might be grossly unjust. 
Сн. VII. There is indeed a grave practical difficulty in effectively trying British subjects for offences committed out of the British dominions, namely the difficulty of witnesses.

An English jury, and it is believed a colonial jury also, will hardly ever convict upon purely written evidence, and it is not only with juries, but with judges, that this difficulty arises. Thus the late Mr. Justice Coleridge, in a judgement, said :-

' The most careful note must often fail to convey the evidence fully in some of its most important elements-those for which the open oral examination of the witness, in presence of prisoner, judge, and jury, is so justly prized. It cannot give the look or manner of the witness, his hesitation, his doubt, or variations of language, his confidence or precipitancy, his calmness or consideration; it cannot give the manner of the prisoner, when that has been important upon the statement of anything of particular moment. Nor could the judge properly take on him to supply any of these defects, who, indeed, will not necessarily be the same on both trials. It is, in short, or it may be, the dead body of the evidence, without its spirit, which is supplied, when given openly and orally, by the ear and eye of those who receive it ;' and other judges have taken the same view.

The provision of the Merchant Shipping Act ', that depositions taken before a justice or British consular officer may be used as evidence, has been nearly useless for the purpose of obtaining convictions for offences.

This difficulty of obtaining a conviction without oral evidence is a difficulty which does not, it is believed, exist, at any rate to such a serious extent, in the ease of foreign courts in Europe, though no doubt it would arise in courts in the United States.

Exceptions in case of erimes committed

There were two exceptions from the old English law. The one was that in case of offences committed within military lines abroad: the Court of the Earl Marshal, now obsolete, had

\footnotetext{
${ }^{1} 57$ \& 58 Vict. c. 60 , s. 69 I, re-enacting s. 270 of 17 \& 18 Vict. c. I04.
} 
jurisdiction and tried the crime according to the law of Cr. VIr. that court, and not according to the course of the common law.

The other was an exeeption which, owing to the necessity abroad, or of the ease applies universally in all countries, namely, where the offence was conmitted at sea. In that ease the Lord High Admiral had jurisdiction to try the offence in his own court, known as the Admiralty Court.

A ship is for most purposes of jurisdiction treated as part of the territory of the nation to which it belongs, and though English writers deny the soundness of the doctrine that a ship is a continuation of the territory, yet in praetice the consequences of that doctrine largely prevail in England.

The Admiralty Court tried, according to the course of the civil law, all offences committed on the high seas, which in England means the sea below low-water mark, and in tidal rivers up to the first bridge ${ }^{1}$. The trial by civil law is declared in the preamble of the Act of $153^{2}$ to be of the nature that before any judgement of death ean be given against the offenders they must plainly confess their offences (which they will never do without torture), or else their offences must be proved by eye-witnesses, who can seldom be got, beeause they are often murdered by the offenders, and also, being mariners and shipmen, often depart without long tarrying to the great cost of the King as well as of those who would pursue the offenders. The Act for this reason proceeded to give to a special commission of oyer and terminer under the Great Seal power to try persons who had committed treason, felony, robbery, or conspiraey at sea, according to the course of the common law, in any part of the kingdom directed by the eommission, as if the offence had been committed there.

In $1699^{3}$ power was given to the commission to try in the

'See ${ }_{5}$ Rich. II. e. 3 , an Aet passed to restrict the encroachments of the admiral on the jurisdiction of the county authorities.

28 Hen. VIII. c. I5.

${ }^{3}$ I I Will. III. c. 7 , which recites that in consequence of $28 \mathrm{Hen}$. VIII. c. 15 trials bofore the admiral were disused. 
Cн. VII. colonies or at sea piracies and robberies committed at sea, and in 1806 the two Acts were extended to all offences committed at sea ${ }^{1}$. Subsequent legislation has extended this law both as regards the offences and the person by whom they are committed, so as to include persons who belong or have recently belonged to British ships, even though they are not British subjects. The flag is thus presumed to bring them within British municipal law.

Existing law as to trial of offences committed

The present law is as follows:-

Any British subject who commits any offence on board a British ship on the high seas or in any foreign port or on board a foreign ship to which he does not belong, can be tried and punished in any British court which would have cognizance of the offence if committed on board a British ship within the ordinary jurisdiction of the court ${ }^{2}$.

Any person who commits an offence against property or person at any place ashore or afloat, and is at that time, or within three months previously has been, employed in any British ship, can be tried and punished by the same court, and in the same place, as if the offence had been committed within the jurisdiction of the Admiralty of England ${ }^{3}$.

Any person who, not being a British subject, commits an offence on board a British ship on the high seas, and is found within the jurisdiction of any court in the British dominious which would have cognizance of the offence if committed within the ordinary jurisdiction of that court, can be tried and punished by that court ${ }^{4}$.

All offences against English law committed within the jurisdiction of the admiralty can now be tried by the ordinary criminal courts in England, and in some cases in the colonies.

The English Criminal Acts of 186 I provide that any offences

${ }^{1} 46$ Geo. III. c. 54 .

${ }^{2} 57 \& 5^{8}$ Vict. c. 60 , s. 686 , re-enacting I $8 \&$ I9 Vict. c. 9I, s. 22, and $30 " \& 31$ Vict. c. I24, s. II.

${ }^{3} 57 \& 58$ Vict. c. 60, s. 687 , re-enacting s. 267 of $17 \& 18$ Vict. c. ro4.

$57 \& 58$ Vict. c. 60, s. 686 , re-enacting s. 21 of I $8 \&$ Ig Vict. c. 9 I. 
under them, if committed at sea, may be tried by the ordinary Cr. VII. criminal courts in England 1 .

But there is no power to try an offence committed on board a foreign ship on the high seas by a British subject who belongs to that ship.

The law on this subject, and on the position of persons Existing detained on board a foreign merchant ship in an English port, law respects is touched on in the following extracts. The law on the latter detention topic is not very clear. Halleck, in his International Law ${ }^{2}$, ers on states as follows :board a foreign

'The rule of law, and the comity and practice of nations, ship. go much farther than these cases of necessity, and allow a merchant vessel of one state, coming into an open port of another voluntarily, for the purposes of lawful trade, to bring with her, and keep over her, to a very considerable extent, the jurisdiction and authority of the laws of her own country, excluding, to this extent, by consequence, the jurisdiction of the local law. This jurisdiction of a nation over its vessels, while lying in the port of another, is wholly exclusive. For any unlawful acts done by her while thus lying in the port of another state, and for all contracts entered into while there, by her masters or owners, she is made answerable to the laws of the place. Nor, if her master or crew, while on board in such port, break the peace of the community by the commission of crimes, can exemption from the local laws be claimed for them. But the eomity and practice of nations have established the rule of international law, that such vessel, so situated, is, for the general purpose of governing and regulating the rights, duties, and obligations of those on board, to be considered as a part of the territory of the nation

${ }_{4} \& 5$ Will. IV. e. 36, s. $22 ; 24 \& 25$ Viet. ce. 94 and $96-100$; and as to the colonies 12 \& 13 Vict. c. 96 . As to tho jurisdiction of the admiral and its application to foreign ships in territorial waters, seo the Franconia case, R. v. Keyn, L. R. 2 Ex. D. 63, and $4 \mathrm{r} \& 42$ Vict. c. 73 , passed in consequence of the decision in that case.

${ }^{2}$ Sir S. Baker's cl., vol. i. p. 230. Sce also Wheaton, International Law (8th ed.), ss. 102, 103. 
Сн. VII. to which she belongs. The local authorities, therefore, have a right to enter on hoard a foreign merchantman in port, for the purpose of inquiry universally, but for the purpose of arrest only in matters within their ascertained jurisdiction.

'It therefore follows, that, with respect to facts happening on board which do not concern the tranquillity of the port, or persons foreign to the crew, or acts committed on board while such vessel was on the high seas, they are not amenable to the territorial justice, and that all such matters are justiciable only by the courts of the country to which the vessel belongs. So firmly is this doctrine incorporated into the practice of nations that the French regard it as a positive rule of international law, and the French laws do not hesitate to prescribe that, when crimes are committed on board a French vessel in a foreign port by one of the erew against another of the same crew, the French consul is to resist the application of the local authority to the case.'

In 1856, the United States Attorney-General gave an opinion ${ }^{1}$ on the following case :-

An American merchant ship, the Atalanta, was on a voyage to New York, and on the high seas a mutiny occurred, and the ship put into Marseilles. On arrival, the mutineers, on the application of the American consul, were imprisoned on shore by the local authorities. Some of them were afterwards placed on board the Atalanta for conveyance to the United States on a charge of crime. Then the French local authorities went on board the Atalanta, and, in spite of the remonstrances of the American consul, forcibly resumed possession of the prisoners, and replaced them in confinement on shore.

The United States Attorney-General advised as follows :-

'In my opinion, when the Atalanta arrived at Marseilles, the master of that ship had lawful power, with aid of the consul, if required, to retain these men on board. Though not citizens of the United States, they were American seamen under voluntary contract for a voyage to New York, whom the local authorities had no power to discharge from their contract. 
' The consideration that they had committed erimes on board the ship, but not withiu the local jurisdiction, for which erimes they were liable to be punished on her reaching New York, did not give to the local authorities any just right to interfere. If crime had been committed while the ship lay in the territorial waters, then the local authorities, and they alone, would have had jurisdiction, and might have gone on board to seize the prisoners by force, but not when no act had been done by them to give jurisdiction of the case to France.

'I transfer the question to the United States, and proceed to suppose that a French merchant ship on her way to Marseilles puts into New York in distress, having at the time mutinous members of her erew confined on board. Could such persons in such a case be lawfully taken away from the custody of the master by the local authorities, with instrumentality of the writ of habeas corpus or otherwise? I think not.'

' My conviction is clear that the local authority, even if it may refuse to aid, cannot lawfully interpose to defeat, the lawful confinement of any members of the crew by the master on loord the ship, with advice and approbation of the consul.'

(After stating the French view of the law as given above.)

"We do not go so far in this as France. I admit, as already stated, the local authority in regard to crimes committed on board a merchantman in the territorial waters; but I deny that the local authority has any right to interfere with persons lawfully detained on board the ship by the laws of the country to which she belongs, as for a crime committed on the high seas among members of the crew, and not justiciable by the foreign jurisdiction. France, at least, cannot deny to us, it would seem, this exception, when she herself claims to extend it so much further, and make it comprehend oceurrences internal to the erew, even though happening in port.

" The doctrine of the pulJlic latw of Europe on this point is well stated by Riquelme, as follows: "Crimes committed on the high seas, whether on board shijs of war or merchantmen, are considered as committed in the territory of the State to which the ship belongs, beeause only the laws of the latter are infringed, and consequently only the jurisdiction of the same is called upon to adjudicate, whether the aceused be of the nationality of the ship or a foreigner, and whether the crime were committed against a fellow countryman, or between foreign passengers.

" If the ship on board of which the crime has been committed arrives then at a port, the jurisdictional right of the territory to which the ship belongs over the accused does not on that account cease. So that if one of these were a foreign subject to which the port at which the ship stops belongs, even in that ease it is the right of the eaptain to detain lim on board, that he may 
Crr. VII. be judged by the tribunals of the ship's country. And if this passenger should get on shore, and should institute before the tribunals of his country proceedings against the captain, the local authority will be incompetent to judge the foreign captain, because the fact in question occurred in a foreign country-that is, on board a foreign merchantman on the high seas-and because, by embarking in that ship, the party is presumed to have submitted himself to the laws of the foreign territory of which the ship constitutes a part."

'I confess myself wholly at a loss, therefore, to see on what assignable ground of strict international right it was that the local authority at Marseilles proceeded in withdrawing these parties from their lawful confinement on board the Atalanta.

'If, indeed, it were the intention of France to try these men for their crime, and it had been committed in the territorial waters so as to be capable of being tried there, then, indeed, we might see cause for withdrawing them from the custody of the ship or consul. But no such thing is proposed in the despatch of M. Baroche.

'If the legality of what has been done be admitted, then municipal crimes perpetrated on the high seas will much of the time escape unpunished. One term of every royage is a foreign port. If a crime other than piracy be committed while on the way thither, and the criminal be detained on board the ship or on shore, subject to the discretion of the consul, he cannot be tried; for the local authority cannot try him, and if he is to be withdrawn from the custody of the ship he cannot be tried in the country to which she belongs, and which alone has jurisdiction.

'Thus, the effect of the course entered upon by the local anthority at Marseilles, if it should be sanctioned by the Emperor's Government, and admitted by the United States, would be to discharge these criminals without punishment, to set the example of immunity of crime in all such cases for the future, and tend to the most calamitous consequences as respects the safety of the commercial marine of both France and the United States.'

'Permit me to add that the United States, while recognizing' the local authority generally in the case of merchant ships, have never claimed nor conceded it as to things not appertaining to the territorial jurisdiction. We have constantly affirmed our right to detain on board our ships, eveu in a foreign port, persons held to such detention by the laws of the United States '.'

Phillimore ${ }^{2}$ says that the masters and crews of ships are

1 The A.-G. referred to Mr. Legare's opinion of July 20, 1842, and to Wheaton's Elements. See and ed.. by Lawrence, p. 207, note ; and Hall, International Law, part ii. ch. iv. $\S \S 5^{8-60}$.

International Lare, vol. iii. p. 603. 
deemed to possess the national character of the ships to which Crr. VIr. they belong during the time of their employment, and refers to the case of the Endranght ${ }^{1}$.

The following cases illustrate the diffieulties which arise with respect to offences at sea:-

Case a.-Three seamen on board a Swedish brig, committed Illustramurder and mutiny on the high seas. On arriving at Brisbane they were handed over to the local police; and then their extradition was demanded by the Swedish consul.

One of the men, a Swede, was surrendered under the Extradition Act, but two of the three men were British subjects, and, though they could not be tried in Queensland, their extradition could not be legally granted because the extradition treaty does not allow the surrender of nationals. Nor could they be delivered under the Foreign Deserters Act, $185^{2}$, because that Act applies only to the delivery of deserters, and not to the surrender of men for the purpose of being tried for crime.

If the men, instead of being handed to the local police, had been kept in custody on board the Swedish ship with a view to being taken back to Sweden, and had sued out a habeas corpus, the question would have arisen whether they were in legal custody while the ship was in port.

Case b.-An Englishman, one of the crew of a German ship, while on the high seas, murdered another member of the crew, also an Englishman, and was put in irons. On the ship arriving at Table Bay in the Cape Colony, the murderer, instead of being kept on board ship, was allowed to land and go free. The authorities of the colony were unable, when the captain of the ship applied to them, either to try the man for the murder, or to detain him with a view to extradition.

If the murderer had not been allowed to go free, and had applied for a habeas corpus, the question would have arisen

1 I Rob., p. 23.

2 I \& I6 Vict. c. 26 , now re-enacted in 57 \& 58 Vict. c. 6o, s. 238. 
Cr. VII. as in the last case, whether he was detained in legal custody on board the German ship while in colonial waters at Table Bay.

Case c.-The crew of an Uruguayan ship committed mutiny and murder on the high seas, the culprits being two Englishmen and an American, while the murdered man was a Russian. The ship was boarded by a French transport, and the culprits were brought to Brest.

The French courts had no jurisdiction, as the crime was committed by aliens on board a foreign ship.

The English courts had no jurisdiction, because the offence was committed on board a foreign ship by Englishmen belonging to that ship.

The Uruguayan Government declined to take any steps in the matter.

Trial of As respects offences on land, legislation has made excepcommitted tions from the law of local jurisdiction to try them when on land committed outside the British dominions, in the following British cases :-

dominions.

(a) Treason ;

(b) Murder and manslaughter;

(c) Offences against the Explosives Act, $188_{3}$;

(d) Slave trade offences;

(e) Bigamy, when the first marriage was in the British dominions ;

$(f)$ Offences such as forgery or perjury committed abroad with reference to proceedings in some English court;

(g) Possession of goods stolen abroad.

In cases $(a)$ and $(d)$, and sometimes in cases $(e)$ and $(f)$, the offences can be tried in any British possession. In the other cases the offences can be tried only in England.

The exceptions are defended on the ground that every British subject, wherever he may be, continues to owe allegiance to the Crown, and therefore to be subject for certain purposes to English municipal law, and that consequently if he does anything contrary to that allegiance or law he is liable, if 
found within the jurisdiction of an English court, to be Cr. VII. punished as if he had committed the offence within the dominions of the Crown.

This doctrine would justify an Act enabling a British subject to be punished not merely for the offences above mentioned, but for all offences. It involves not merely the right to try a British subject, but the duty of the British subject to obey English municipal law. This doctrine of obedience is comparatively simple in the case of offences like murder, which are considered to be offences by the law of every civilized country, but would lead to extraordinary complications if it were extended to all the numerous minor offences which may be committed under English law. Practically, the doctrine must be limited to the common crimes recognized as such by all civilized peoples.

The doctrine is fully recognized by international law and Foreign by the law of foreign countries. In, it is believed, all foreign doctrines. countries (except the United States, where the English common law prevails), criminal jurisdiction is considered to be personal and not local, so that the subjects of a state are liable to be punished for crimes committed abroad ${ }^{1}$.

The French law was amended in 1866 , and provides for the trial of every French subject accused of 'crimes' abroad, thus excluding ' contraventions' and 'délits.'

In England, the tendency has been rather to surrender British subjects for trial abroad under the Extradition Acts than to provide for their trial in England. The Extradition Act, 1870 , was so framed as to authorize the surrender of them, though most treaties have been so drawn as to preclude it ${ }^{2}$.

As respects offences committed on land abroad, the first Act allowing them to be tried according to the course of the

1 Lewis, For. Jur.; pp. 18-20. [See, however, Holland, Jurispmedence, 8thed., Pr. 374-7.] The principle of personal jurisdiction is recognized in the Indian Code of Criminal Procedure (v. of 1898 ), s. 188.

${ }^{2} 33 \& 34$ Vict. c. 52. See fi. v. Wilson, L. R. 3 Q. B. D. 42. 
CH. VII. common law ${ }^{1}$, was 33 Hen. VIII. c. 23 , which provided that if

English statute law relating to these offences. a person, being examined by the King's council or any three of them on a charge of treason or murder, confessed the offence, or was thought by the council to be vehemently suspected of the offence, a commission of oyer and terminer might be issued into such county as should be appointed by the King, with power to inquire of, hear, and determine such offence in whatever place, within the King's dominions or without, it had been committed.

The Act was repealed as respects treasons in $I 554^{2}$. The rest of the Act, and the subsequent amending Acts, are now replaced by the provisions of the Act of $186 \mathrm{I}^{3}$, under which no examination of the Privy Council or special commission of oyer and terminer is required, and any person charged with murder or manslaughter on land, either within British dominions or without, can be tried in any part of England in which he is found.

The next general Act was in $1699^{4}$, and provides that if any governor or commander-in-chief, \&c., of any plantation or colony within His Majesty's dominions shall be guilty of oppressing any of His Majesty's subjects within his government or command, or shall be guilty of any other crime or offence contrary to the laws of this realm that are in force within his government or command, such oppression, crime, and offence shall be inquired of, heard, and determined in the King's Bench, or before such commissioners in such county of this realm as shall be assigned by His Majesty's commission.

This was amended in 1802 by the Criminal Jurisdiction Act of that year ${ }^{5}$, which recites that persons holding employments out of Great Britain often escape punishment for

1 As to offences committed within military lines or at sea, see above, pp. 128, I29. It was by a special commission under 33 Hen. VIII. c. 23 that Governor Wall was tried and convicted for murdering a negro twenty years previously by illegal flogging while Governor of Goree, in West Africa, 28 St. Tr. 5 I.

2 I \& 2 Philip \& Mary, c. Io.

4 Ir Will. III. c. I2. 
offences committed by them for want of courts having sufficient Cr. VII. jurisdiction, and that such persons cannot be tried in Great Britain, and that it is therefore expedient that the like prorisions to those contained in the Acts above mentioned should be extended to the punishment of such offenders. It then enacts that if any person employed by or in the service of His Majesty in any civil or military station, office, or eapacity out of Great Britain, or holding or exercising any public station, office, capacity, or employment out of Great Britain, shall be guilty of any crime, misdemeanour, or offence in the execution or under colour or in the exercise of any such station, office, capacity, or employment, the crime, offence, and misdemeanour may be inquired of, heard, and determined in the King's Bench, either upon information or upon indictment.

These Acts are still in force, though the High Court has absorbed the King's Bench. Under them it has been held, first, that the Act of I699 only applied to misdemeanours, and afterwards that the Act of 1802 also only applied to misdemeanours, because it recited the Act of 1699 and did not itself contain any express mention of felony, and referred to proceedings by information as well as by indictment ${ }^{1}$. The Acts have been applied in fact to offences committed outside the British dominions.

Similar provisions are to be found in several enactments relating to India ${ }^{2}$.

The Acts directing persons to be tried in England for offences committed outside England involve the assumption that English officials carry with them the obligation to obey English municipal law, and that they will be punished criminally if they fail to do so.

The Acts relating to India provide for Indian judges taking evidence upon a mandamus from the King's Bench, if required

1 R. v. Shawe, 5 Maule \& Selwyn, 403.

2 ro Geo. III. c. 47 ; 13 Geo. III. c. 63 , ss. $39-45$; 24 Geo. III. sess. 2 , c. 25 ; 26 Geo. III. c. 57 . Of these, 13 Geo. III. c. 63 extends to folonies : see s. 45 . 
CH. VII. for the purpose of a criminal prosecution in England under the Acts, and upon a warrant from the Lord Chancellor or the Speaker if required in the House of Lords or in the House of Commons. The defendant in any such case was to be allowed to cross-examine, and the depositions were to be used as evidence in England as if the witnesses were present.

The Act of $1802{ }^{1}$ contained similar provisions as to evidence in the case of prosecutions under that Act or under the Act of 1699 . It referred to taking evidence in capital cases, which at that date might be assumed to include all felonies, but, as above mentioned, the Act did not itself provide for the trial of felonies. The Act was made use of in one wellknown case, that of General Picton, who was afterwards killed at Waterloo ${ }^{2}$.

No power to try for offence on board a foreign ship to which British subject belongs.

It will be observed that none of these Acts make any provision for trying a British subject for an offence committed on board a foreign ship to which he belongs. The reasons for this provision not being made are as follows :-

A British sailor serving on board a foreign ship acquires for some purposes the national character of the ship ${ }^{3}$. He ceases for the time to be subject to English municipal law, and has contracted to be subject to the municipal law of the foreign country to which the ship belongs so far as such law affects seamen, and therefore to submit to the punishment for mutiny or other offences against that municipal law. But he has not submitted to be tried by British courts for offences against the foreign municipal law; and if he can be so tried, and the rest of the crew cannot, justice may not be done, especially as offences on board ship are often much mixed up with questions of civil right.

42 Geo. III. c. 85 .

2 30 State Trials, 225. As regards taking evidence in one part of the British dominions for use in another, see also $6 \& 7$ Vict. c. 98 , s. 4 ; 22 Vict. c. 20 ; and $48 \& 49$ Vict. c. 74 .

"See the quotation of United States Attorney-General's opinion above, p. 132, and Phillimore, International Law, vol. i. p. 487 . 
The same argument does not quite apply to the case of Cr. VII. a British subject in a foreign colony on land, for not only are the powers of the eaptain of a ship and his relations to the erew of a special character, but if the British subject is on land in a foreign country he is naturally amenable to the eourts of that country, whereas if he is on board a foreign ship which puts into an English port, he comes within the jurisdiction of a British court before he reaches the foreign country.

Where the offence is, like murder or manslaughter, an offence against all eivilized law as well as against English municipal law, the objection to trying the British sailor for the offence is not quite so strong; but those offences, when committed on board ship, are often only the conclusion of a series of acts connected with the civil rights or with the diseipline of the ship, and therefore closely connected with the enforcement of the foreign municipal law as respeets merehant shipping.

Suppose, for instance, that a British seaman, being one of the crew of a Swedish merehant ship, in the course of a dispute about wages or food, commits some offence against the Swedish merehant shipping law for which the master can under Swedish law punish him. The seaman denies the alleged offence and resists his punishment and kills the master.

The seaman may wish to be tried by his own countrymen, in the hope that a jury may believe that the foreigner had bullied him. The Swedes, on the other hand, may wish, in the interests of the discipline of their own merchant ships, to try the man by their own law.

To allow the authorities in a British port into whieh the Swedish ship put to try the man aceording to English law would be inconsistent with the rule of international law, whether as adopted by the French or as adopted by the opinion of the United States Attorney-General ${ }^{1}$.

\footnotetext{
- See above, p. r32. Cp. also the Franconia case, $h . v$. Keyn, L. R. a Ex. D.
} 
Cr. VII. The foregoing considerations do not apply to offences

Offences

on land

in non.

Christian or barbarous countries.

Trial of oflences by British subjects in areas.

(a) Newfoundland. committed on land. Wherever there is a civilized, or perhaps it might be said an organized, Government there are local courts and local officials capable of dealing with such offences.

But where the Government of the locality is a Mahommedan or other non-Christian Government, whose social organization and views of justice differ widely from those of European or Christian Governments, or where the territory is under a barbarous Government, it is impossible to submit British subjects to non-Christian law or to trust to the justice of local courts, and therefore either crimes committed by British subjects must be left unpunished or power must be taken for the British Government to punish them. Hence arose what are known as the capitulations, and consular jurisdiction.

Before the great extension in recent years of this jurisdiction it had for the same reasons as those above mentioned been found necessary to provide for the punishment of crimes committed by British subjects in certain special areas in different parts of the world, which were not under any organized government and to which these subjects resorted for fishing and trade.

Thus as early as 1699 an Act, after reciting that thefts, robberies, murders, and other felonies upon the land in Newfoundland and the islands adjacent thereto often escaped unpunished because the trial of such offenders had hitherto been ordered and adjudged in no other court of justice but before the Lord High Constable and Earl Marshal in England, enacted that all such offences might be tried in any county in England by virtue of the King's commission of oyer and terminer and gaol delivery ${ }^{1}$, as if committed within the realm. This Act was repealed when an organized Government was established in Newfoundland in 1832 .

In 1817 the settlement in the Bay of Honduras was in the

63. Piracy, being an offence against all nations, can be tried by any court independently of the nationality of the offenders or their ship.

Io \& I I Will. III. c. 25, s. 13. 
possession and under the protection of the British Crown, but Crr. VII. not within the dominions of the Crown, and offences committed there and also in the South Pacific, both on the high duras, seas and on land ontside the dominions of the Crown, by the New masters and erews of British ships and other persons who had otaheite for the most part deserted from then or left their ships and Pacific. continued to reside in the islands, went unpunished, so that great scandal was raised against the character of British and other European traders. Consequently an imperial Act was passed to provide that murders and manslaughters committed on land at the settlement in Honduras by any person within the settlement, or committed in the islands of New Zealand and Otaheite, or within any other islands or places not within the British dominions nor subject to any European state or power, nor within the territory of the United States of America, by any person sailing in or belonging to a British ship, or who had sailed in or belonged to and had quitted any British ship to live in any such island or place, might be tried and punished in any part of the dominions of the Crown under the Act ${ }^{1}$. The Act has been repealed as to Honduras, New Zealand, and Otaheite, but is still in force for other islands and places.

In 1828 the Act ${ }^{2}$ which authorized the establishment of courts of judicature in New South Wales and Van Dieman's Land authorized those courts to try all offences of whatever nature committed on the sea or where the admiral hath jurisdiction, or committed in the Pacific Occan by any such persons as are specified in the foregoing provisions of the Act of I 8 I 7 .

In 1836 it was found that as the inhabitants of the terri- (c) Cape. tories adjacent to the colony of the Cape of Good Hope and south of the twenty-fifth degree of south latitude were in an uncivilized state, offenees against their persons and property

${ }^{1} 57$ Geo. III. c. 53. See al ${ }^{4} 6$ Geo. III. c. 54 , which was one of the $\Lambda$ cts amending the $\Lambda$ ct 33 IIen. VIII. c. 23, beforo mentioned.

9 Gieo. IV, e. 83. 
CH. VII. were frequently committed by British subjects with impunity. Therefore an Act $^{1}$ was passed extending to all British subjects within the above-mentioned territories the laws in force in the colony for the punishment of crime, and providing that they should be tried and punished as if they had been committed in the colony. The Act also authorized the issue of commissions to British subjects in these territories conferring on them the powers of a magistrate for the purpose of arrest, committing to custody, and bringing to trial all persons charged with such offences ${ }^{2}$.

This Aet was in $1863^{3}$ repealed and re-enacted, with two additions, the effect of which was

(I) to exclude plaees within the jurisdiction of any civilized goverument; and

(2) to give the courts of the colony of Natal concurrent jurisdiction to try the cases.

(d) Sierra Provision similar to that made for the Cape was made in Leone. I86I for the territories adjacent to the colony of Sierra Leone, extending five hundred miles east of that colony as well as a considerable distance both north and south of it ${ }^{4}$.

(e) Chinn. In 1833 powers for the regulation of trade were vested in certain officers called 'superintendents of the China trade,' and on the constitution of the eolony of Hong-Kong the governor of that colony was made ehief superintendent of the China trade. And in 1843 the Crown was authorized by a commission under the Great Seal to empower the chief superintendent of the China trade, as long as he is also governor of HongKong, to legislate for the peace, order, and good government of Her Majesty's subjects being within the dominions of the

$16 \& 7$ Will. IV. c. 57.

2 The Act contained an express saving that nothing in any commission should be construed as investing the Crown with any clain to dominion or sovereignty over the territories, or should derogate from the rights of the tribes and people inhabiting the territories or their chiefs or rulers to such sovereignty.

3 By $26 \& 27$ Vict. c. 35 , now superseded by $53 \& 54$ Vict. c. 37.

424 \& 25 Vict.c. 3 I, now superseded by $53 \& 54$ Vict. c. 37. 
Emperor of China, or being in any ship or vessel at a distance Cr. VII. of not more than one hundred miles from the coast of China, and to enforce such legislation by penalties and forfeitures. Power was also given to the Queen in Council to make for the government of Her Majesty's subjects within these limits any ordinance which she could make for the government of the island of Hong-Kong ${ }^{1}$.

The Act of 1843 was repealed by the Foreign Jurisdiction Act, $1878^{2}$, which however reproduced the power of the Crown to legislate for British subjects in vessels within one hundred miles of the Chinese coast.

The provisions of the Acts of $S_{1}{ }_{7}$ and $1828^{3}$ for the trial of murders committed in the Pacific Ocean were not found sufficient, and two Acts of 1872 and $1875^{4}$ further dealt with the matter, by creating certain offences connected with the kidnapping of natives and by taking power to seize vessels, and provision was made for the trial of offenders under the Acts.

The Act of 1872 assumed that the offenders were to be . tried in the courts of one of the Australasian colonies, and only made provision for obtaining evidence beyond the jurisdiction of those colonies. The Act of 1875 went further. It gave jurisdiction to all Vice-Admiralty Courts as well as the High Court of Admiralty of England to try and condemn the ships seized, and also gave the Qucen power to exercise jurisdiction over British subjects within any islands in the Pacific Ocean, not being within Her Majesty's dominions nor within the jurisdiction of any civilized power, in the same manner as if the jurisdiction had been acquired by the cession or conquest of territory.

It also authorized the Queen :-

(a) To create the office of high commissioner for these

${ }^{1} 3 \& 4$ Will. IV. c. $93 ; 6 \& 7$ Vict. c. 8 o.

$241 \& 42$ Vict. c. 67 , s. 6 , now superseded by $53 \& 54$ Viet. c. 37 . s. 14.

3 Sce above, p. I43.

4 $35 \& 3^{6}$ Vict. c. $19 ; 3^{8} \& 39$ Vict. c. 5 r. 
Cr. VII. islands, or some of them, and to confer on him porver to make regulation for the government of British subjects there;

(b) To create a court of justice with civil and admiralty jurisdiction over all British subjects within the islands to which the authority of the high commissioner extended, with power to try crimes either there or on the high seas; and

(c) To legislate for British subjects in the islands.

The Act contained a provision saving native customs and negativing any presumption of sovereignty, similar to that in the Cape Act of $183^{6}$. The Act, though not repealed, is in part made unnecessary by the Foreign Jurisdiction Act, I $890^{1}$, the enactments of which are wider. Under the Acts of 1872 and 1875 a high commissioner has been constituted and courts set up. In March, I89.3, an Order in Council ${ }^{2}$ was passed under the Act of I 890 continuing the high commissioner and authorizing the appointment of a special commissioner and also of an assistant commissioner, who is in effect a judicial officer and head of the court.

The Order was declared to apply to persons who were British subjects, and to natives and foreigners in so far as by reason of being or having been on board a British ship or otherwise they had come under the duty of allegiance to Her Majesty. Crimes committed by any such persons against natives or foreigners are to be tried as if they were committed against British subjects.

But in civil suits the consent of the Government of the foreigner has to be given, as in the case of other orders under the Foreign Jurisdiction Acts ${ }^{3}$.

Power is given to the high commissioner to legislate. In practice the high commissioner is also governor of the colony of Fiji.

In all three cases the Acts and Orders in Council have a double aspect, that of making British subjects justiciable for acts done out of the British dominions, and that of apply-

${ }^{1} 53$ \& 54 Vict. c. 37 , set out in App. VII.

${ }^{2}$ Stat. $R . \&$ 0., 1893, p. $312 . \quad 3$ Ibid. p. 347 ; and see ch. viii. p. 156. 
ing to them British municipal law, either by implication, or Crr. VII. by express application of English or colonial law, or by giving power to legislate for them.

No mention has been made above of extra-territorial juris- Jurisdicdiction exercised at sea in the case of sea fisheries, and for prevent the protection of the revenue. The reason for the omission is and prothat such jurisdiction is rather a local extension of territorial tect sea jurisdiction than a true extra-territorial jurisdiction. The fisheries. right to stop ships on the high seas for the purpose of preventing smuggling has been acquiesced in by different nations, and therefore may be treated as having been recognized by international law as an exercise of territorial jurisdiction ".

The same is the case with some fisheries. In the case of other fisheries, treaties have been made providing for the regulation of the fisheries by the different states whose subjects fish there. The question was much discussed in the arbitration proceedings about the Behring Sea fur seals ${ }^{2}$.

The extent to which British jurisdiction ean and cannot be exercised over foreigners in territorial waters ${ }^{3}$ is also rather a question of the limits of territorial than of extra-territorial jurisdiction.

'Hall, Internutional Lavo, part ii. c. 4. §59; For. Jur., part iii. c. 4. § 103.

${ }^{2}$ Parl. P., 1893 , United States, No. 3 (ch. vi); R. v. Keyn, L. R. 2 Ex. D. 63 .

${ }^{3}$ See Hall, For. Jur., part iii. c. 4 . $\$$ 107. The question was argued in R. v. Keyn, ubi supra. 


\section{CHAPTER VIII}

\section{CONSULAR JURISDICTION}

Сн. VIII. Consuls are appointed by the Crown in European and - other Christian states, and receive an exequatur from, and Consuls in are recognized as British officials by, the Governments of
civilized are states. those states. But they perform merely ministerial acts, and have no judicial power or coercive jurisdiction.

They may act as arbitrators between British subjects, and they perform various duties under the Merchant Shipping Acts in respect of the documents which ships have to carry, the transfer of ships, sending home destitute seamen, and other matters. They also take affidavits and perform notarial acts.

They may be authorized to solemnize marriages where one of the parties is a British subject, but this authority can only be given if the state in which the consul acts consents to or acquiesces in its exercise. The Govermment of the German Empire objects to the solemnization of marriages by consuls, and consequently authority for this purpose is now never given to consuls in Germany.

But in Mahommedan and other non-Christian states, whose social system and habits and views of morality and justicc differ widely from those which prevail in Christian countries, the consuls, though appointed and receiving an exequatur in the same manner, exercise judicial and coercive jurisdiction. This jurisdiction is exercised in Turkey under what are known as the Capitulations, the origin of which, and indeed of consular jurisdiction in general, goes far back into history.

Owing to historical reasons-partly to the Roman system 
of leaving the coloniae under their local law and introducing Cr. VIII. the Roman law only for the purpose of Roman eitizens, and partly to other causes-it became a familiar practice to have The Capidwelling in a territory a body of persons having an internal form of government different from that of the territory. Cornewall Lewis observes that one form of extra-territorial jurisdiction, which has existed from the earliest times, is that of factories established for commercial purposes by a more civilized, in the territory of a less civilized, nation, with the consent of the latter: and that factories have always been allowed to appoint magistrates of their own and to exercise an independent jurisdiction, from the Greek factory of Naucratis in ancient Egypt and the factories of the Genoese and Venetians in the Levant in the middle ages to those of the English East India Company in Hindostan 1.

The Hanseatie merchants had what was equivalent to a factory in the Steelyard in London, which was known as the Guildhalla Teulonicorum, had privileges granted to them under Letters Patent, and were under an alderman appointed by themselves ${ }^{2}$.

England also had factories in the Levant under the Levant Company, and in Russia. The Russia Company is virtually extinct, but traces of it remain on the statute-book in the provision of the Marriage Aet as to marriages in a Russian factory $^{3}$. The Levant Company was extinguished in $1825^{4}$, and its extinction led to the enactments relating to foreign jurisdiction, the history of which is stated in the Laconia case ${ }^{5}$ and in the learned and interesting memorandum of the late Mr. Hope Scott, printed in Appendix VI.

1 Lewis on For. Jur., pp. 93, 14x. See also Rashluall, Universities of Europe in the Middle Ages, i. $153,178$.

2 Sce Loftie, Hist. of London, vol. i. p. I72; and the 1 ets, 4 Edw. IV. r. 5 ; 19 Hen. VII. c. 23 .

34 Gico. IV. c. 91, now repealed by $55 \& 56$ Vict. c. 23.

- IBy 6 Geo. IV. c. 33, which transferred the juriscliction of tho consuls of the company to the consuls appointed by the Crown.

- Reported is L'apayanni v. The Iiussian Steam Navigation anal Thading company, a Moore, I. C. (N.S.) 16I. 
Сн. virr. Briefly, the Capitulations were treaties with the British Crown made by the Sultan of Turkcy with respect to the whole of the Ottoman dominions, directing disputes, civil or criminal, between British subjects to be left to the decision of the ambassador or consul according to custom, and providing that if a British subject is accused of crime or is sued civilly by an Ottoman subject the ease shall not proceed unless some British official is present in court.

They also gave certain exemptions to the persons, houses, and property of British subjects with respect to arrest, entry, and taxation. They did not surrender the right to punish British subjects for offences against the local law. They did not in terms confer upon the British Crown or the consul jurisdiction to try British subjects for offences, or to determine disputes arising between British subjects ${ }^{1}$.

Similar treaties were made from time to time by the Sultan with other European nations. The jurisdiction under them had been exercised for many years, and customs had grown up under them by which the jurisdiction had been in practice extended beyond the original grant.

These Capitulations were prima facie protective, i.e. were for the protection of the British or other European subjects against oppression by the Turkish authorities. The protective character of them is divelt upon by $\mathrm{Mr}$. Hall ${ }^{2}$. The privileges granted were treated as involving an implied obligation on the part of the British Crown to provide against the concession of them injuring the Turkish sovereign, and therefore to maintain order among British subjects and repress and punish crime ${ }^{3}$.

In considering these Capitulations the international must be distinguished from the municipal aspect.

Internationally, the Capitulations are made with the Crown,

1 See Capitulations of 1675 confirmed by the Treaty of the Dardanelles, I809 (Hertslet, Commercial Treaties, ii. p. 346).

2 For. Jur., part iii. ch. ii. §65.

${ }^{3}$ See circular after passing of Act of $18_{43}$, Parl. P., 1845, vol. lii, No. 127 . 
and the jurisdiction under them is to be exercised under the Cr. VIII. authority of the Crown by officers called consuls.

The method in which the Crown exercises that jurisdiction is a matter for municipal law. Practically until 1825 it was exercised by the Levant Company and by the consuls of that Company.

The abolition of the Company in 1825 gave rise to the difficulties specified in Mr. Hope-Scott's memorandum ${ }^{1}$. But these difficulties arose out of defects in the municipal law, and not out of any international complications.

The Foreign Jurisdiction Act of $1843^{2}$ was passed in accor- The dance with the recommendations in $\mathrm{Mr}$. Hope-Scott's memo- Foreign randum. The Act recited that by treaty, capitulation, grant, tion Acts, usage, sufferance, and other lawful means Her Majesty had power and jurisdiction within divers countries and places out of Her Majesty's dominions; and that doubts laving arisen how far the exercise of such power and jurisdiction was controlled by and dependent on the larrs and customs of this realm, it was expedient that the doubts should be removed. It then authorized the Queen to hold, exercise, and enjoy any power or jurisdiction which Her Majesty might at any time have within any place out of Her Majesty's dominions in the same and as ample a manner as if Her Majesty had acquired such power or jurisdiction by the cession or conquest of territory. It went on to enact that everything done in pursuance of the power and jurisdiction should be treated as valid and effectual as though the same had been done according to the local law then in force in such place.

Consequently every Order in Conncil made for the purpose of the exercise of jurisdiction takes effect only as a local law, and therefore does not operate beyond the territorial limits of the territory. It cannot therefore, without express power from Parliament, authorize anything to be done outside the territory, such as sending persons, whether convicted of or charged with offences outside the territory, to a colony either

$$
\text { App VI } \quad{ }^{2} 6 \& 7 \text { Vict. c. } 94 .
$$


Cн. VIII. to be tried or to undergo their sentence. Still less can it authorize the deportation of persons for the purpose of preventing them from either committing offences or being an annoyance to the sovereign of the territory.

Power of The provisions of the Act of I 843 included a power to send tion. offenders convicted of offences to a colony to undergo their sentence, and also to send them for trial to a British colony, but not a power to deport them by way either of punishment or prevention.

The power of deportation had been exercised for many years before 1843 , and continued to be so exercised after the Act of 1843 came into operation ${ }^{1}$. After some years its legality was challenged on the ground of its being an extraterritorial power. It was then legalized by an Act of $1875^{2}$.

An Act of $1878^{3}$ was also passed to give power to the Crown to extend to any place where the Crown exercised foreign jurisdiction certain imperial Acts dealing with extra-territorial matters.

The same Act also enlarged the power of the Crown by Order in Council to confer jurisdiction on colonial courts in respect of matters, civil or criminal, arising within the territory under the Foreign Jurisdiction Act.

It also provided that where a foreign country was not subject to any Government from whom Her Majesty the Queen might obtain jurisdiction, as recited in the Act of 1843 , the Queen should by virtue of the Act have jurisdiction over Her subjects for the time being resident in or resorting to that country. The object of this enactment was to enable British subjects in uncivilized territories which were not under any protectorate or any civilized Government to be punished for offences committed there. At the time when it was passed, British subjects on the river Congo and in other parts of Africa had committed heinous offences for which there was no power to try and punish them.

\footnotetext{
1 Sce Parl. P., I845, vol. lii, No. I 27. $\quad{ }^{2} 3^{8} \& 39$ Vict. c. 85.

${ }^{3} 4$ I \& 42 Vict. c. 67.
} 
The Act of $18+3$ and all the amending Aets were consoli- Crr. VIII. dated in $1890^{1}$.

In considering the Orders in Council issued under the $\Lambda$ cts the nait. must be recollected that in any legal proceding, civil or jure of tho eriminal, the validity of any Order can be challenged on the tion unground that it is ultra vires, as, for instance, that it dealt Lets. with jurisdiction which the Crown did not possess or purported to confer powers in excess of the jurisdiction possessed by the Crown.

The Acts provide that any court may refer to a Secretary of State a question respecting the existence and extent of any power or jurisdiction of the Crown in any foreign country, and the answer of the Secretary of State is final ${ }^{2}$; but not only would the answer of the Secretary of State be merely to the question of fact as to what jurisdiction had been in an international sense acquired by the Crown, but it would be for the court to draw the inference from the facts stated by the Secretary of State, and that inference might be adverse to the Order in Conncil.

The British Crown is by English law recognized as having complete power to govern and legislate for any country acquired by conquest or cession. Consequently the effect of the Act of 1843 was to confer on the Crown the same power of administration and legislation in any foreign country so far as the jurisdiction or power there acquired extends, even though the Crown did nct possess territorial sovereignty. It therefore recognized the fact that sovereignty might exist without territorial dominion. The sovereignty, however, which is conferred may be considered part of the sovereignty naturally belonging to the sovereign of the territory, and either delegated or transferred by the territorial sovereign to the British Crown. But in some of the treaties there is no express delegation or transfer. 'The jurisdiction in such eases is only implied, and may thercfore be considered to have been aequired by usage or sufferance. 
Crr. VIII. The Act of I 843 does not confer territorial, or indeed any jurisdiction on the Crown, but facilitates the exercise by the Crown and its officers of the jurisdiction acquired $a b$ extra. The extent of the jurisdiction depends, therefore, on the treaty or usage, and not upon the Act ${ }^{1}$. Also the Act does not expressly apply to cascs where jurisdiction is acquired by conquest or where sovereignty is acquired by cession, and it may be doubted whether the words 'or other lawful means' can be held to apply in either of these cases 2

The jurisdiction acquired has two aspects :-

(I) the administration of the law by British officers within the dominions of another sovereign; and

(2) the law which is applicable to British subjects for whom law is to be so administered.

In either case it is assumed that if the Order in Council with respect to the jurisdiction in any territory is silent, English law applies to all British subjects within the territory, but frequently the Order in Council legislates for those subjects. It has been already seen that such legislation eannot of itself extend beyond the territorial limits within which the jurisdiction may be exercised. Hence the necessity of expressly authorizing the Crown to apply the Acts dealing with offences at sea or with fugitive offenders ${ }^{3}$ or other matters beyond the territorial limits.

What per- In speaking of British subjects, difficulties may often arise sons are subject to the jurisdiction, and what law is applicable. as to who are the British subjects who are entitled to the protection and subject to the jurisdiction. Thus, for instance, a question may arise whether the class would include an alien naturalized in a British possession or the grandson born in a foreign country of a British subject resident there, who is only entitled to be deemed a British subject by virtue of the

${ }^{1}$ See The Imperial Japanese Gort. v. Peninsular and Oriental Steam Natigation Company, L. R. (1895), A. C. 644 .

2 Hall, For. Jur., part iii. ch. ii. §8o, considers that extradition implies territorial sovereignty. It is in fact exereised under the Imperial Aet by British consuls.

${ }^{3} 53 \& 54$ Vict. c. 37 , s. 5 . 
special statutes ${ }^{1}$. It has also been the practice for a British Сн. VIII. consul to grant protection to divers persons who are sometimes even natives of the foreign eountry in which he exercises jurisdiction. These persons are ealled British protected persons. The practice of granting this protection has of late years been exercised very sparingly by British officials, but is still exercised freely by the officials of other European countries. The treaties usually refer only to British subjects.

The subjects of Indian native states under the protection of the British Crown have been expressly directed by an imperial Act to be treated in the same manner as British protected persons under the Foreign Jurisdietion Aets ${ }^{2}$, and the natives of other British protected states may no doubt justly elaim to be treated as British protected persons for the purpose of foreign jurisdiction.

By English law, a direction to a court to administer a particular law is considered to be an applieation of that law to the persons to whom that law is to be administered. Consequently a direction by an Order in Comeil to a consular court to administer the law of England is prima facie an application of the law of England to all British persons within the jurisdiction of the court.

This application is natural enough as regards British subjects who, as stated above ${ }^{3}$, are as a rule, when outside the British dominions, subject to English law. But the application of English law is not so obviously right in the case of British protected persons, especially where they are subjects of a state which, though under the protection, is not part of the dominions, of the British Crown, and for whom no British legislature legislates, such, for instanee, as the natives of Indian or Malay protected states. In their case, however, the sovereign of the protected state ought to delegate the power to the British Crown to legislate for his subjects; and if there is no express delegation, such a delegation might

1 This subject is dealt with in Ifall, For. Jur., pp. 123-31.

$53 \& 54$ Vict. c. 37 , s. 15.

${ }^{3}$ Ch. vii. p. 137. 
Cr. VIII. perhaps be implied by the fact of the protection as regards the subjects when ontside the territorial limits of the protected state. It might also be argued that if such a subject accepts the protection of the British Crown in a foreign country, he must also accept the burden of obedience to English law and submit to the jurisdiction of the British consul. In either case English law can only be applied as in the case of a new British settlement, so far as it is applicable ${ }^{1}$.

In the case of foreigners, that is to say persons who are not British subjects or British protected persons, there cannot ordinarily without delegation from their own sovereign be an obligation on their part to obey English law, nor any jurisdiction in a British court over them.

In a civil case a man may be justiciable in a court held by authority of a sovereign who did not make the law applicable to that man. The law so applicable may depend upon his status or domicile, and what law is so applicable may in some cases be a matter of great doubt ${ }^{2}$. But there is no reason why such a foreigner should not sue a British subject in a court of the British consul in accordance with the general maxim actor sequitur forum rei. The foreigner in that case -only accepts the jurisdiction pro tanto, just as where a foreign sovereign sues an Englishman in England.

In a criminal case it is different. A man is, as a rule, only liable to a criminal procceding in any court where he is bound to obey the law administered by the court. But here again there seems no reason why a foreigner not subject to the jurisdiction of the court should not prosecute criminally a person who, by reason of his British nationality, is subject to that jurisdiction.

In the Ottoman dominions the custom had grown up before 1843 of the courts dealing freely with all suits brought before

1 In the case of succession or marriage, or any other matter dependent on a person's status or domicile, the law applicable to him would usually not be English law.

2 See Hall, For. Jur., p. 162. 
them, at least in civil cases, whatever the nationality of the Cir. VIII. parties ${ }^{1}$; and even though the Ottoman Government did not surrender the right of arresting and proseenting a British subject for crime, the custom had grown up of the prosecution being frequently conducted in the eonsular court.

The first Orders in Couneil with reference both to civil and criminal jurisdiction issued under the Act of 1843 directed the consuls to continue to exercise all such power and jurisdiction as had theretofore been customarily exercised by them or their predecessors in office; and the Order in Council issued in June, I 844 , gave the consuls the necessary power to try all crimes and offences committed by British subjects within the Ottoman dominions over which Her Majesty had jurisdietion.

In 1863 a case arose of cross suits between British subjects and a Russian company, and the Judicial Committee of the Privy Council deeided that a British court could not exercise any jurisdiction over a foreigner unless the foreign state to which he belonged had consented to the exereise of that jurisdiction ${ }^{2}$. It is probably due to this deeision that the provisions of the Orders in Couneil requiring the consent of the Govermment of a foreigner who sued in the court or prosecuted a criminal in the court were inserted.

The Ottoman dominions included Egypt, Tunis, Tripoli, In what and Cyprus, in each of which there were local courts subject conpitulato the Supreme Court of Constantinople. But the courts in tions exist. Egypt are suspended as to mixed suits by an Order in Couneil of February, $1876^{3}$, so long as the international courts continue. Those in Tunis were abolished in 1889 as respects all matters within the jurisdiction of the Fiench courts established there ${ }^{4}$; while the courts in Cyprus were super-

1 See I'url. P., 1845, vol. lii, No. 127, which shows various suits against foreign defendants, and which contains circulars issucd after the passing of tho Act of 1843 .

2 The Laconin, 2 Mroo. P. C. (N.S.) I6r.

stret. li. \& O. liev., vol. iii. p. 690.

' Ibid. 1) 697. 
Cr. VIII. seded on Great Britain undertaking the administration of Cyprus in $1878^{1}$.

The system of capitulations originally established for the Ottoman dominions was extended to other Mahommedan and eastern countries, namely, Morocco, Muscat, Persia, including the Persian coast and islands ${ }^{2}$, China, Corea, Japan, and Siam.

The same system was also extended to Madagascar until it became part of France in 1896 , and to Zanzibar, which is now a protectorate. But as regards these other countries there is no ancient custom to justify anything done under the Order. The jurisdiction of the Crown depends upon the treaty made in each case, and upon any practice which has subsequently arisen, and which may be held to amount to usage.

The treaties were not quite the same in all cases, and, as mentioned before, did not in all cases delegate jurisdiction ${ }^{3}$.

Abnormal In the treaty of December, 1884, with the King of the exclusive jurisdiction of British Consuls in the Congo Free States. Belgians, acting as founder of and in the name of the International Association for the Congo, power is given to the British Crown to appoint consuls to reside in the free states under the Association. The Association undertakes to protect these consuls, and there is a provision that every British consul may hold his consular court for the district assigned to him, and shall exercise sole and exclusive jurisdiction, both civil and criminal, over the persons and property of British subjects within the same in accordance with British law. British subjects, however, are to obey the laws of the free states applicable to foreigners, but infractions of them are only to be justiciable by a British consular court.

This exclusive jurisdiction over British subjects seems very exceptional. Nor is it quite consistent with the provision,

1 Stat. R. \& O. Rev., p. 396.

2 A separate Order in Council has been issued for the Persian coast and islands, but only applies to places within the Persian dominions (Stat. R. \& O. Rev., vol. iii. p. 796).

${ }^{3}$ See the comments on these points in Hall, For. Jur., p. 149. 
which appears to have been copied from the treaty with China cur. VIII. and Siam, directing the consul on complaint against a British subject by an inhabitant to decide the matter amicably, and if he cannot do so to request the assistance of the authorities to decide it ${ }^{1}$.

The Order for the Ottoman dominions of $1873^{2}$ contains a The complete law for the administration of the Foreign Jurisdiction Ottoman Act in the Ottoman dominions. Order.

It provides that the civil and criminal jurisdiction shall be * administered according to English law for the time being, and according to the procedure and practice of English courts, but saves any reasonable custom existing in the Ottoman dominions except where that custom is contrary to some specific provision of the Order. The Order established a Supreme Consular Court for the Ottoman dominions, consisting of a judge appointed by the Queen under Her Sign Manual, who must have been an English or Irish barrister or a Scotch advocate of not less than seven years' standing in each case, and an additional judge appointed by a Secretary of State, who must have been a judge of a British possession or Cyprus, or such a barrister or advocate as above mentioned.

The judge and additional judge form the court of appeal from the court for Egypt.

There is a chief consular court for Egypt, to which judges are appointed by separate warrant under the King's Sign Manual.

Every commissioned consular officer, with such exceptions as a Secretary of State makes, forms for his own consular district a provincial consular court, and an uncommissioned consular officer, with such exceptions as the Supreme Court makes, also forms a provincial court.

All resident British subjects, except native Indians, are required to register themselves at the consulate, and on failure to regrister are not entitled to be considered British

2 State Papers, vol. 1xxv. p. 29. $\quad{ }^{2}$ Stut. L. \& O. Mier, vol. iii. p. 587. 
Cr. VIII. subjects, and are liable to a fine and are amenable to the criminal jurisdiction of the court. A native Indian subject may or may not register himself, but if unregistered is not entitled to protection and is not within the jurisdietion of the consular court.

The Supreme Court ordinarily sits at Constantinople, and has an original jurisdiction concurrent with the court of Egypt and the provincial courts. The judge ean visit in a magisterial or judicial capacity any place in the Ottoman dominions and there try any case, civil or criminal. The * rules of procedure for the court, the fees to be taken, and the provisions as to summoning witnesses are contained in the Order. Certain eases are tried either by a jury or with assessors.

Where an Ottoman subject or a foreigner desires to institute in any of these courts a suit against a British subject, or a British subject desires to institute a suit of a civil nature against an Ottoman subjeet or a foreigner, the court may determine it, provided that the subject or foreigner first obtains and files in the court the consent in writing of the competent authority on behalf of the Ottoman Porte or of his own nation to his submitting and does submit to the jurisdiction of the court, and if required gives security to abide the dccision of the court and to pay fees, damages, \&c.

If the evidence of a British subject is required in any court or before a judicial officer of the Ottoman dominions: or a foreign state in amity with Great Britain, the court can compel the attendance of that subject.

The Supreme Court has jurisdiction in bankruptcy, viceadmiralty as regards vessels coming within the Ottoman dominions, Iunacy, matrimonial causes (except the jurisdiction relative to dissolution, nullity, or jactitation of marriage), and is a court of probate.

As regards criminal matters, crimes which in England are capital are tried by the Supreme Court with a jury, or, if a jury eannot be obtained, with an assessor or assessors. 
The lists of jurors are made out annually from among the Cr. VIII. male British subjects resident in the dominions having a competent knowledge of Euglish and having a gross income of not less than $\mathfrak{E}_{5}$ o a year. Other crimes above the degree of misdemeanour, if not tried summarily, are tried with a jury or assessors. Other classes of criminal cases may, having regard to the law and practice of England, be directed by the Supreme Court to be tried summarily.

Before the Supreme Court was constituted with judges of legal training capital crimes were sent to Malta for trial.

The provincial courts can only try cases which can be adequately punished by imprisonment for three months or a fine of $£_{2}$. In other cases the court must either send for trial to England, Bombay, or Malta, or reserve the case for the Supreme Court or in Egypt for the chief court for Egypt.

The court for Egypt and every provincial court must send to the Supreme Court a report of the sentence of the court in every case tried on indictment, and the Supreme Court, if required by the Secretary of State, transmits the same to him.

A person convicted elsewhere than in the Supreme Court has an appeal to the Supreme Court, which may report to the Secretary of State recommending the mitigation or remission of any punishment awarded by the inferior court.

In capital cases the judge orders judgement of death to be entered on record. The judgement is then reported, together with the notes of evidence, to the Secretary of State for his direction.

An offender sentenced to imprisonment may be imprisoned Imprisonat any place in the Ottoman dominions approved by the ment and Secretary of State, or may be sent, if a native of India, tion. to Bombay, and in any other case to Malta or Gibraltar, to undergo his sentence.

Where it is proved that there is reasonable ground for apprehending that a British subject is about to commit a breach of the public peace or that his acts are likely to 
Cr. VIII. produce a breach of the public peace, or where he has been convicted of any crime before the consular court or before any court in the sentence of which the consular officer concurs, the court may require him to give security for his future good behaviour, and if he refuses may deport him, if a native of India, to Bombay, if a native of Malta, to Malta, and if a native of Gibraltar, to Gibraltar ; in any other case to England. If the order is made by any court other than the Supreme Court there is an appeal to that court. The person ordered to be deported is embarked in custody on board any British or other fit vessel bound to the place of deportation, and if he returns is liable to imprisonment and fine.

Other

Foreign

The Orders made for other countries-Persia, Moroceo, the

Jurisdic-

tion

Orders.

Persian coast and islands, China, Japan, Corea, Siam-are all framed on the lines of the Ottoman Order, though they vary in detail.

Persia and Thus in Persia there is no special judicial officer. The Persian (iulf. consul generally holds the chief court.

That Order also gives the consul-general power to legislate for British subjects and for British protected subjects so far as they are subject to the Order. It also declares that crimes and wrongs affecting natives or foreigners are punishable or cognizable with the consent of the native, or foreigner, as if they affected British subjects.

A separate Order has been made with respect to the Persian coast and islands, i.e. the coast and islands of the Persian Gulf and Gulf of Oman within the dominion of Persia. Under this Order the consul-general or political resident in the Persian Gulf holds the court, and Indian, and not English, law is applied!

Morocco. In the case of Morocco special provision is made to meet a special provision in the treaty as to mixed civil cases between British and Moorish subjects.

The Morocco Order also gives the Supreme Court of Gibraltar concurrent original jurisdiction in civil matters between British

1 This Order is applied to the Somali coast protectorate. 
subjeets, and in criminal cases where the defendant is a Cr. viIr. British subject. It provides for the recovery in the consular court of certain taxes due to the Moorish Government by British subjects and for the punishment of smuggling.

The Order for Siam extends to foreigners whose Governments Siam. have consented to the exercise of power by His Majesty. It also makes penal certain acts by British subjects, and, like the Persian Order, gives the consul-general power to legislate for British subjects resident in or resorting to Siam.

For China and Corea there is a Supreme Court, with a chief China and. justice and an assistant judge, who sit at Shanghai. These judges are all appointed by the King under Royal Sign Manual, and must be members of seven years' standing of the Bar of England, Scotland, or Ireland.

The King's Minister in China can legislate for the government of British subjects in or resorting to China ${ }^{1}$.

In Corea the consul-general holds the court, subject to an appeal to the Supreme Court for China and Corea.

The consular jurisdiction formerly exercised in Japan has Japan. recently come to an end, in pursuance of the treaty of July 16, $1894^{2}$, and the British Crown has now no more jurisdiction over British subjects in Japan than in any European state.

A curious result of the foreign jurisdiction formerly exercised in Japan occurred recently. In 1892 a collision oecurred in Japancse waters between the Chishima, an imperial Japanese cruiser, and the Ravenna, belonging to the British P. and O. Steam Navigation Company. The Japanese Government sued the company in the consular court to recover damages. The company counterclaimed against the Government, and urged that as the Government had submitted to the jurisdiction of the court, the court had jurisdiction to try the claim of the company against

${ }^{1} \mathrm{Cp}$. power of $\mathrm{King}$ in Council to legislate for British subjects in China or at sea within 100 miles of China, 53 \& 54 Vict. c. 37, s. 14, re-enacting $6 \& 7$ Vict. c. $80 ; 4$ I \& 42 Viet. e. 67 .

2 See the Orders in Council of Oct. 7, 1899, and Mareh 3, 1900. 
Cr. VIII. the Government. But the Judicial Committee held that the treaty gave no jurisdiction in any claim against a Japanese subject, to say nothing of the Government, and that the Government could not be said to have submitted to the juris: diction because, having surrendered by treaty the right to try a claim against a British subject, they had no option but to sue the company in the British court ${ }^{\text {. }}$

${ }^{1}$ Imperial Japanese Gort. v. P. \& O. Co., L. R. [1895]. A. C. 644. The judgement observes that the Order in Council could not confer on the British court a wider jurisdiction than is given by the treaty, but possibly the court might be bound to conform to the order and leave the party to a diplomatic remedy; also that the Order prescribes how the jurisdiction is to be exercised, but what jurisdiction the court possesses must be determined ab extra. 


\section{CHAPTER IX}

\section{JURISDICTION IN BRITISH PROTECTORATES AND THE}

POSITION OF FOREIGN SUBJECTS IN THEM

A Britisi protectorate is a country which is not within Cr. IX. the British dominions, but as regards its foreign relations is under the exclusive control of the King, so that its govern- Definition ment cannot hold direct communication with any other foreign protecpower, nor a foreign power with that government ${ }^{\text {. }}$

The British Crown, either by treaty, by sufferance, or by force, assumes over a defined territory a protectorate in this sense, and thus excludes the government of the protected territory from making treaties with other foreign powers, or declaring peace or war with them, or receiving ambassadors or consuls from them; whilst, on the other hand, the Crown undertakes to protect the inhabitants of the territory from interference by any foreign power.

In other respects the powers of the Crown over the pro-

' See Sir H. Maine, quoted below, p. ${ }^{167} 7$ and Sir Travers Twiss, Law of Nutions, ed. $r 884, \S \S 25,26$ : "There are exceptional instances in which the communications of in independent state with foreign powers are earried on through the medium of a third power, which has been acknowledged by public treaties as the autherized organ of such communications. In certain of these cases the intermedate power has been recognized by foreign states as exercising a protection over the weaker state, and has been acknowledged in terms as the protecting power. . . In the case of protected states, which are not members of the family of nations, the relations between them and the protecting power are for the most part founded upon some compact between thom ; but as the protected state does not maintain any relations whatever with foreign powers, it is virtually a dependency of the protecting powor, leing distinguished from ordinary dependencies in this respect, that its rights are secured and its obligations limited by compact.' 
Сн. IX. tected territory vary with the different cases, but in every case the territory is, as respects internal sovereignty ${ }^{1}$, left more or less under an independent government.

Effect of exclusion of external relations.

By the exclusion of external relations'with foreign powers, the protector is held according to international law to assume the external sovereignty of the protected territory, and the territory becomes what is termed by international writers a semi-sovereign state, or, as Sir T. Twiss prefers to call it, a 'protected independent state'?

Sir Henry Maine says ${ }^{3}$ :- ' It is necessary to the Austinian theory that the all-powerful portion of the community which makes laws should not be divisible, that it should not share its power with anybody else, and Austin himself speaks with some contempt of the semi-sovereign or demi-sovereign states which are recognized by the classical writers on international law. But this indivisibility of sovereignty, though it belongs to Austin's system, does not belong to international law. The powers of sovereigns are a bundle or collection of powers, and they may be separated one from another. Thus a ruler may administer civil and criminal justice, may make laws for his subjects and for his territory, may exercise power over

1 The division of sovereignty into internal and external is a convenient form of expression, and seems well established in international law.

External sovereignty means 'the independence of one political society in respect to all other political societies,' the mark of which is complete liberty of action in its relation with other states, i. e. power independently of any otler state to make peace or war with, receive embassies from, and conclude treaties with other states.

Internal sovereignty means the sovereignty "which is inherent in the people of any state or vested in its ruler by its municipal constitution,' and the marks of it are power to organize its life in its own way and to have its own legislature and judiciary. Wheaton, $\S 5, \mathrm{pp} .35,3^{6}$; Hall, International Lav, pp. 50, 5I ; Calvo, Le droit internationat theorique ef pratique (Paris, I880-1), §§ 39-4I, 104, 106, 734 .

"The recognition of these semi-sovereign states seems universal. See, as respects the United Kingdom, Phillimore, Int. Law, vol. i. p. 94 seq. ; Hall, Int. Law, §§ 3, 4, pp. 24, 25; as respects United States, Wheaton, § 13 , p. 59 ; Halleck, ch. iii. § I 7, p. 65; as respects France, Calvo, $\$ \S 4 \mathrm{r}, 62,734$; as respects Germany, Heffter, transl. by Bergson, 1866, §§ 18, 19; and Bluntschli, transl. by Lardy, I881, $\$ 78$.

3 International Law (1888), p. $5^{8 .}$ 
life and death, and may levy taxes and dues, but nevertheless he may be debarred from making war and peace, and from having foreign relations with any authority outside his territory. This, in point of fact, is the exact condition of the native princes of India; and states of this kind are at the present moment rising in all the more barbarous portions of the world. In the protectorates which Germany, France, Italy, and Spain have established in the Australasian seas, and on the coast of Africa, there is no attempt made to annex the land, or to found a colony in the old sense of the word, but the local tribes are forbidden all foreign relations except those permitted by the protecting state.'

The instances given by writers on intermational law of Instanees semi-sovereign states are all in Europe or bordered by the of semiNediterranean Sea, with the exception of the Indians in the states.

United States of America. In two well-known cases the Supreme Court decided that a tribe of Indians had remained an independent state under the protection of the United States, by virtue of treaties entered into originally with the British Government, and subsequently with the United States ${ }^{1}$.

Since the Ionian Islands became part of the kingdom of Greece in 1863 , there has not been any case of a civilized, or one should rather say a Christian, state under British protection; and all the protectorates which are now of so much importance, whether under the protection of the United Kingdom or of other states, are non-Christian.

Writers on international law never worked out the result Protecof a state being protected or semi-sovercign, even where it internawas Christian, and they did not until reeently even notice tiona. the position of a protected non-Christian state. This position, though unrecognized by international law writers and indeed by every foreign power except Spain and Holland, had been worked out in practice in India to a large extent

1 Wheaton (d. 1863), § 14, p. 68. Sir 'J. Twiss, however, refers to the native states of India (Law of Nations, ed. 1884, § 26). 
Cr. IX. and with very great variety. During the last twenty years the question has, in the scramble for Africa, assumed European importance, and a system is now being gradually developed not merely as regards British protectorates, but also as regards those of other Powers.

In this respect, as in others, e.g. consular jurisdiction, international law alters and grows with changing circumstances, international compacts, and even municipal law; while international law writers invent principles or apply old principles so as to suit accomplished facts.

It is generally recognized that the rules of international law apply only to Christian countries in Europe and America, and that if they apply at all to non-Christian states ${ }^{1}$ they so apply with considerable modifications. Modifications must therefore also be made in the application of international law to the relations of Christian states inter se in their dealings with non-Christian states. It is said that Great Britain was the only country which refused at the Berlin Conference of I 884-5 to recognize the necessity for such modifications. Germany, at any rate, recognized the necessity, and in an early stage of the modern African protectorates Prince Bismarck is said to have declared that he intended to make the African protectorates of which he had been the founder resemble India under the government of the East India Company ${ }^{2}$.

British protectorates:

The various protectorates of Great Britain may be grouped as follows :-

The Indian group, consisting, apart from the protected

1 Recent treaties with Japan (see p. 163 supra) and the decision in Brinckley v. A.-G., L. R. I5 P. D. 76, as to Japanese marriages, seem to place Japan in the same position as Christian states.

2 Twiss, § 96 ; Phillimore, vol. i. pp. 80-87; Hall, Int. Law, p. гзо, $\S 38$; Calvo, $\S \S 25,69,70$. International law writers refer in a very meagre manner to some of these modifications in connexion with the Mohammedan states bordering on the Mediterranean, but (with the exception of Twiss [and Westlake, Chapters on the Principles of International Law, p. 2I I sqq.]) make no reference to India or any Asiatic barbarous states. See also Maine, Int. Lav, p. 59 ; Hall, For. Jur., p. 207, § 94. 
states in India, of the protected local chiefs on the Arabian Crr. IX. coast near Aden and the island of Socotra, all under the Indian Government; of the Somali coast, lately transferred to groun. the management of the Secretary of State for Foreign Affairs; of the Maldive Islands under the Government of Ceylon; and of various islands under the Government of Mauritius. In these protectorates there is no interference with the internal government, nor indeed any interference except the payment or receipt of a subsidy, and the exclusion of dealings with or interference by other nations.

The Malay group, consisting of the Malay states in the Malay Burmese peninsula near the Straits Settlements, and the three group. protectorates in Borneo-North Borneo, Brunei, and Sarawak -administered under the Colonial Secretary.

The African group, consisting of British Central Africa, African East Africa, Uganda, and Zanzibar, which are administered group. under the Secretary of State for Foreign Affairs; and of Nigeria (including the territories recently under the Royal Niger Company ${ }^{1}$ ), the territories now under the British South Africa Company, and Basutoland and British Bechuanaland, which are administered under the Secretary of State for the Colonies.

In the Pacifie there are still one or two groups of pro- The Pacific tected islands, but other places have been made part of colonies, steh as the Cook Islands and the Kermadec Islands, now united to New Zealand, while the British part of New Guinea has been made into a separate colony, administered under the superintendence of the Government of Queensland. Norfolk Island is administered by New South Wales. Pitcairn Island has been placed under the High Commissioner of the Western Pacific.

Of the Malay group, the protectorates in Borneo were all Borneo. made such in 1888 by three separate agreements between the British Crown on one side and the chartered North

1 [The eharter of this company has now been revoked; see $62 \& 63$ Vict. c. 43, and the Southern Nigerian Order in Council, 1899.] 
CH. IX. Borneo Company on the other. In each case the agreement provided that the territory should continue to be governed as an independent state under the protection of Great Britain, and that this protection should confer no right on the Queen's Government to interfere with the internal administration of the state further than is provided by the agreement, or (in the case of North Borneo) by the charter.

The relations between each state and all foreign states were to be conducted by Her Majesty's Government and in accordance with its directions, and the protected state agreed to abide by and give effect to the decision of Her Majesty's Government in the case of any difference with a foreign state.

Her Majesty was to have the right to establish in any part of the state consular officers, who would receive exequaturs in the name of the Government of the state and enjoy the privileges usually granted to consular officers.

British subjects were to have the rights of the most favoured nation and of the subjects of the state.

No cession was to be made to any foreign state or the subjects thereof without the consent of Her Majesty's Government.

Sarawak In the case of Sarawak and Brunei the Crown must deand Brunei. termine the questions of succession. In Brunei exclusive jurisdiction, civil and criminal, over British subjects and their property was reserved to Her Britannic Majesty, to be exercised by such consul or other officers as Her Majesty might appoint for the purpose; and the same jurisdiction was reserved over foreign subjects enjoying British protection, and also in cases between British subjects and the subjects of a third power whose Government consents. In mixed civil suits between British subjects and the subjects of the protected state the trial was to be in the court of the defendant's nation, but in the presence of an officer of the plaintiff's nation ${ }^{1}$.

' See Hertslet, Commercial Tieaties, vol. xviii. pp. 225-8. It must be 
The Brunei Order in Couneil (November 22, 1890) pro- Cи. IX. vides for the constitution of Consular Courts to be held at Brunei and elsewhere, from which there is to be an appeal to the Supreme Court of the Straits Settlements; these courts are to have ciril and eriminal jurisdiction, and not only over British subjects and their property, but also over foreigners whose Government has consented to the exercise of such jurisdiction by the British Crown, and over foreign plaintiffs who eomply with eertain conditions.

The North Borneo Company obtained a charter from the Crown, with power to accept a concession of government from the Sultan of Brunei, and the Company does in fact exercise sovereign powers and issue eoins, and does not trade. The governor of North Borneo, though appointed by the Company, has to be approved by the Secretary of State.

In the ease of Sarawak, the Rajah had obtained the eoncession of the government from the Sultan of Brumei.

These two cases are anomalous, inasmuch as according to constitutional doctrine any sovereign power aequired by a British subjeet is acquired on behalf of the Crown, whereas the agreement of 1888 recognized the Company in the one case and the Rajah in the other as independent states, exercising sovereignty independently of the Crown.

The Niger Territories were until reently under the Niger The Nigor Company, which had obtained a charter from the Crowu, and Terrihad been reeognized by international agreements made with (iermany and France. The eharter authorized them to execute all sovereign rights aequired by them. These rights lepended partly upon cession and treaty, and partly upon what had been acquired by foree, or by the fact of the

chserved that the treaties refer to Her Majesty and Her Majesty's (iovermment without any mention of the Queen of Great Britain in the preamble, or, with one or two exceptions, in the main part of the agreement. The agreements seem to be almost identical, excopt as mentioned in the text, and except in the preambles, which in the case of Borneo and Sarawak refer to the grants and commissions obtained from the mative sovereigns. 
Сн. IX. Company having been the most powerful governing body within the territory.

The power of the Company to legislate for and administer justice to foreigners would therefore appear to have depended not so much upon such international rules as apply in the case of protectorates acquired by the Crown, as upon the actual physical state of affairs existing within the territories.

The British Central Africa, East Africa, and Uganda protectorates are all administered by a commissioner and consulgeneral appointed by the Secretary of State, who has general powers of legislation and administration, subject to the Secretary of State.

The title of consul-general, where there is no foreign Power capable of giving an exequatur to a consul, seems out of place, and is merely a survival indicating and due to the fact that foreign jurisdiction first arose in case of capitulations under the Ottoman Government.

It is difficult to distinguish these protectorates from any territory inhabited by uncivilized tribes which has been taken possession of in the name of the British Crown. But technically they are not part of the British dominions.

Two types of protectorates.

Apart from the Indian group, there are two types of British protectorates: one where there is an organized government under à sovereign, with more or less distinct boundaries; the other where there is no organized goverument over the whole of the territory, but where either a petty chief governs his own tribe or sometimes a combination of several tribes, or where there is even still less eivilization and merely tribes, perhaps nomad. In these cases there are often no specific boundaries.s. But these two types run into each other, so that it may be difficult in some cases to determine whether a protectorate belongs to one or the other.

There is also the case of the chartered companies, in which there is a protectorate of one type or the other under the organized Christian government formed by the chartered 
company, while that company is in its turn subordinate to Crr. IX. the British Government.

Protectorates of the first type are those of the Malay states, Zanzibar, and Brunei, to which perhaps may be added Muscat, if indeed it is a protectorate.

Protectorates of the second type are the East African, Somali, Uganda, Nigeria, the Somali coast, and the Pacific islands.

The cases of Socotra, of the protected Arab chiefs near Aden, and of the Maldive Islands under Ceylon, do not distinctly fall within either type, and the interference of the British Goverument is so small that it may be disregarded.

Since the extinction of the Royal Niger Company there are now only two chartered companies, the well-known South Africa Chartered Company under Mr. Rhodes, and the British North Borneo Company. But with these companies should be classed the Rajah of Sarawak, an Englishman, who acquired a petty sovereignty in part of Borneo from the native Sultan of Brunei and is now recognized as head of a state under British protection.

In the first type of protectorates there is a native sovereign (i) Where with an organized government capable of sending and receiv- an existing diplomatic representatives and making a treaty. In the ing organbest organized protectorates a British officer, called a Resident, vernment. resides in the country and advises on all matters of government, legislative or execntive, while the British Government undertalies to maintain internal as well as external peace; but does not directly interfere with the internal government. And the natives of the state continue under their local law and local courts and administration.

In protectorates of the second type there is no sovereign or (b) Whero organized government. What may be termed the tribal there is government is left untouched, but the general goverument governof the country, i.e. the maintenance of peace, is carried on by a British officer under the name of commissioner or consulgencral. There is no general treaty, though conventions are 
Cr. IX. usually made with the petty kings or tribal chiefs, by which they cede their territories or surrender external and internal sovereign rights to the British Government. In these protectorates there is no legislation or exercise of judicial funetions properly so called for the natives, but the British official requires the chiefs to observe certain rules in governing their tribes ${ }^{1}$. Thus he prohibits war and slave-trading.

In both types of protectorates external foreign relations are entirely managed by the British Government; and strangers, whether British subjects or other Europeans, are mostly exempt from obedience to the native law and the native courts or officials.

As to the internal government, the types differ as regards the amount of internal sovereignty which is assumed by the British Crown as protecting state. In the first type hardly any of the internal sovereignty is assumed directly, although in the Malay states much indirect influence may be exercised through the Resident.

But in protectorates of the second type a very large amount of internal sovereignty has been assumed and exercised. As regards the position of British subjects in a protected state of either type the internal sovereignty is only a matter of British municipal law, and no difficulty arises about it in either type of protectorate if the municipal law is in fact made sufficient.

The posi- But the position of foreigners, e.g. the subjects of other foreigners European states, has to be considered both from the point of in British protectorates. view of international as well as of municipal law.

Internationally the question is how far the internal sovereignty can be exercised against foreigners without the consent of themselves or their Government.

The rule that a Christian state cannot aequire jurisdiction in the territory of a third Power over the subjects of another Christian state without the consent or acquiescence of the

1 [Perhaps this statement needs qualification as to some of the African protectorates.-C. P.I.] 
latter applies to European or independent states, but does Cur. IX. not seem applicable to protectorates of the second type, even if it applies to any protectorate. Foreign nations, Germany in particular, appear to hold that the rule does not so apply ${ }^{1}$ The general principles, so far as respects foreigners in a protectorate, would seem to work out as follows:-

As the protector stands between the protected state and foreign Powers, both as the sole channel of communication and as shielding the protected state from their attacks, foreign Powers must seek from the protector redress for any injuries which either directly or in the persons of their subjects they suffer from the protected state ${ }^{2}$. The Powers must also seck from the protector that justice for their subjects which they cannot get from the local courts of an uncivilized state, and would get from their consuls if they were not excluded.

The protector must, therefore, have power to secure subjects of foreign Powers from injury within the protected state $^{3}$. Whether the protector exercises that power directly

1 See judgement in The Laconia, 2 Moore, P. C. (N. S.) p. I6r, and above, p. I57. As to Germany, see p. I77, 11. 3. As to Franee, compare the treaties with Annam and Cambodia, State Papers, vol. Ixv. p. 375 and vol. lxxv. p. 992. In Tunis, French legislation establishing French courts for all persons was also enacted by a decree of the Bey of Tunis (State Papers, vol. Ixxiv. p. 693).

2 See Calvo, $\S \S 34,734,735$; of. also $\S \S 35^{8}$, 2344; Bluntsehli, $\S \S 380-8$.

3 Compare also the undertaking of foreign powers in the general Act of the Conference of Berlin, signed February 26, I885 (Parl. P., I886, C. 4739). The last paragraph of Artiele 30 is as follows :-'La GrandeBretagne s'engage à protéger les négociants étrangers de toutes les nations faisant le commerce dans les parties du cours du Niger qui sont ou seront sous sa souveraineté ou son Protectorat, comme s'ils étaient ses propres sujets, pourvu toutefois que ces négociants se conforment aux Règlements qui sont ou seront établis en vertu de ce qui précède.'

Articles $3^{r}$ and 32 contain a similar engagement on the part of France and other foreign powers having rights of sovereignty or protectorite in the hasin of the Niger.

Article 35 is as follows:- 'Les Puissances Signataires du présent Acto reconnaissent l'obligation d'assurer, dans Ies territoires occupés par elles sur les cotes du continent africain, l'existence d'une autoritó suffisanto pour faire respecter les droits acruis, lo cas ichéant, la liberto du commerce et du transit dans los conditions où elle est stipulée.' 
Cir. IX. or through the medium of the local Government of the pro-

Foreigners justiciable and punishable.

tected state is immaterial as regards any foreign Power.

But the protector must also, as correlative with his duty of protecting subjects of foreign Powers from injury and supplying them with justice, have a right as against those Powers to keep their subjects when resorting to the protected state from injuring others, and to punish them if they are wrongdoers. The protector must be responsible to foreign Powers for the proper exercise of this right; but if exercised through a proper court, whether it is exercised directly or through the medium of the local Government of the protected state, is immaterial as between the protector and the foreign Power, and is merely an internal question as between the protector and the protected state; and the mode of exercise of the right may vary infinitely with the various circumstances of the protected states.

A foreign Power, therefore, which is excluded from holding direct communication with the protected state, cannot complain if the protector of that state exercises jurisdiction over the subjects of the foreign Porver who resort there.

In the absence, therefore, of any special agreement it seems, to say the least, consistent with the principles of international law, that when the Crown has assumed a protectorate in the sense before mentioned over an uncivilized state, it should have power to legislate for and punish persons resorting there who are not natives of that state.

This position is strengthened by the provisions of Article 34 of the General Act of the Conference of Berlin, I885 ${ }^{1}$, which

1 Acte Général de la Conférence de Berlin, February, 1885 (Art. 34), (Purl, P., 1886, c. 4739) :-

' La Puissance qui dorénavant prendra possession d'un territoire sur' les côtes du continent africain situé en dehors de ses possessions actuelles, ou qui, n'en ayant pas eu jusque-là, viendrait à en acquérir, et de même ia Puissance qui y assumera un protectorat, accompagnera l'acte respectif d'une notification adressée aux autres Puissances signataires du présent Acte, afin de les mettre à même de faire valoir, s'il y a lieu, leurs réclamations' (Le Partage politique de l'Afrique, by Banning, 1888, p. 179). 
provides that a Power who assumes a protectorate on the Cr. IX. coasts of Africa is to notify it to the other Powers who signed the Act, in order that they may complain if necessary.

That article, which must now, it is presumed, be considered as international law for the uncivilized countries on the Afriean eoast, shows that by the proclamation of a protectorate over those eountries, the rights of other European Powers are either exeluded or limited ${ }^{1}$; and a Power which makes no objeetion when the protectorate is signified must be presumed to have assented to such exelusion or limitation.

This article must be construed so as to enable the protector to give effect to the undertaking in Articles 30 and 35 of this General Act, to protect foreign subjeets, and maintain authority sufficient to proteet existing rights and the freedom of trade $\%$

The eonstruetion which the German Government plaeed - upon the Article is shown by the letter of protection given on February 27, $188_{5}$, immediately after the Conference was concluded, to the German East African Company. That letter gave the Company jurisdiction orer subjects of foreign Powers sojourning within the area protected ${ }^{3}$.

1 It is said that in a comntry over which there is noteritorial jurisdiction which can be recognized by civilized Powers, every eivilized Power has equal jurisdiction (Hall, Int. Lax, p. 257). If this was the case with the portion of the African coast to which the proclamation of protectorate applied, the proclamation would elearly, when notified, exclude the equal jurisdiction of other European Powers.

${ }^{3}$ See these articles, quoted above, p. 175, n. 3 .

3 Charter of Protection to the Societr lor German Colonization for their territorial aequisitions in EAST AFrICA.

'We, Willak, \&c., ordain as follows:

'The present presidents of the society for German colonization, Dr. Karl Peters and our Chamberlain Felix, Count Behr-Bandelin, having sought our protection for the territorial acquisitions of the society in East Africa, west of the empiro of the Sultun of Zanzibar, and outside of tho suzerainty ("Oberhoheit") of other powers, and the treaties lately coneluded by the said Dr. Karl Peters with tho rulers of Usagara, \&e., by which these territories have been eeded to him for the Gerhan Colonial Socioty, with sovereign rights ("Landesholeit") over the same, having been laid before us, with the petition to place theso torritories under our suzerainty, we hereby declare that we have aceepted the suzerainty; 
Cr. IX. The main objection to holding that the protector should

Suggested objection to giving power to Crown over foreigners in protectorate.

lave power over subjects of European Powers within a protectorate appears to rest upon the maxims of territoriality already mentioned ${ }^{1}$, and on the doctrine that the jurisdiction in a protected state must be extra-territorial, because 'the very meaning of a protected state is that the territory remains independent.'

This doctrine is based on the Austinian theory, objected to by Sir Henry Maine in the passage above quoted ${ }^{2}$, of the indivisibility of sovereignty, and ignores the distinction between external sovereignty and internal sovereignty which is recognized by writers on international law. According to that distinction a state may be independent as regards internal, but not as regards external sovereignty, and that is the case with the protectorates now in question.

If 'territory' is considered to mean the area over which complete sovereignty is exercised by some one sovereign, the reply is that there may be extra-territorial sovereignty. As Sir Henry Maine says ${ }^{3}$, 'Sovereignty was not always territorial; it was not always associated with a definite portion of the earth's surface.' That sovereignty need not be necessarily territorial is pointed out by Mr. Hope in his Memorandum of $1843^{4}$. The acceptance of the principle is also shown by and have placed under our imperial protection the territories in question, reserving to ourselves a right of deciding hereafter respecting any further acquisitions in the same district which may be proved to have been obtained by legal contract by the society or by their legitimate successors.

'We grant unto the said society, on the condition that it remains German, and that the members of the board of directors, or other persons entrusted with its management, are subjects of the German empire, as well as to the legitimate successors of this society under the same conditions, the authority to exercise all rights arising from the treaties submitted to us, including that of jurisdiction over both the natives and the subjects of Germany and of other nations established in those territories, or sojourning there for commercial or other purposes, under the superintendence of our Government, subject to further regulations to be issued by us, and supplementary additions to this, our Charter of Protection."

\footnotetext{
1 p. 123.

${ }^{2}$ p. 166.

${ }^{3}$ Int. Law, p. 56. See also Hall, Int. Law, p. 257 ; Heffter, $\S 65$.

1 Printed in $\mathrm{App}$. VI. See p. 243.
} 
the Foreign Jurisdiction Acts and the numerous Orders in Сн. IX. Council made under them ${ }^{1}$.

But the sounder view to take is that 'territory' means the Sovearea in which any of the powers of sovereignty, external or reignty is area in which any of the powers of sovereignty, external or divisible, interual, can be exercised. and internationally

Sir Henry Maine, in the passage above quoted, points out only exterthat the rights of sovereignty are divisible, and that the nal sovesovereign who exercises the external sovereignty need not be need be the same as the sovereign who exercises the internal sovereignty; and that the rights of the internal sovereignty are also divisible, and may be exereised partly by one sovereign and partly by another.

This division of sovereignty is also shown by the existence of consular jurisdiction, and as regards English law by the Foreign Jurisdiction Acts.

The jurisdiction of the British Crown, which is com- monly called consular jurisdiction, in Turkey, is clearly a portion of the sovereignty which might be exercised by the Sultan. Whether it was eeded by the Sultan, or obtained by sufferance equivalent to cession, and whether it is or is not a power delegated by him, is immaterial.

If the rights of sovereignty, whether external or internal, are divided, the defined area within which any portion of those rights is exerciseable is the territory within the meaning of the maxim above quoted of the sovereign possessing that portion of the rights of sovereignty.

Thus a protected state is a territory for the purpose of giving effect to the external sovereignty acquired by the protector.

If this view is sound, the jurisdiction will depend on the

1 The punishment of offences committed on board ship or in foreign countries, which is recognized by British, German, and Freneh law, also shows this. The doctrine that the ship is a continuation of the territory, even if sound, which is not admitted by Englisl writers (see Hall, Int. Law, p. 258; Calvo, vol. ii. Nationalite de Natire; Heffter, $\S 78$ ), is a legal fiction, invented for the purpose of justifying the extra-teritorial jurisdiction, by those who held strongly tho connexion between sovereignty and a defined territory. 
Сн. IX. existence in fact of the assumption of the protectorate, and not on the question whether some naked chief living in the country is or is not sufficiently civilized to cede jurisdiction, or has or has not by some informal agreement in fact ceded it. It really seems absurd that the question of the jurisdiction of a British court should depend upon such points.

The rule of international law, that 'as a matter of right no state can claim jurisdiction of any kind within the territorial limits of another state,' was limited by the court in the Laconia case to European or Christian states and to independent states ${ }^{1}$. The rule, therefore, is inapplicable to the present case, as the protected state is neither European nor Christian nor completely independent.

The Crown therefore, by virtue of its assumption of the external sovereignty, has from the point of view of international law certain legislative and judicial jurisdiction for the purpose of dealing with foreigners.

If foreigners wish to enter, travel in, or settle in British protected territory, we can say to them, as in the case of our own territory ${ }^{2}$, we will not admit you except on the same condition on which we admit our own subjects, namely, that you submit to our tribunals.

A question may be raised whether that jurisdiction can only be acquired by cession.

If, as is above argued, the protector has a portion of the complete sovereignty of the protected state, there seems no reason why such portion of sovereignty should not be acquired in the same way as complete territorial sovereignty, namely, by conquest, cession, or occupation.

It must be recollected that in the case of an uncivilized state, cession may be obtained by consent without any treaty, and that 'consent may be expressed by constant usage, permitted and acquiesced in by the authorities of the state,

1 a MI00. P. C. (N.S.), I6r.

2 See Phillimore, vol. i. p. 446; Halleck, vol. i. p. 349 ; Hall, Int. Law', p. 52 ; Heffter, $\$ \S 60-62$; Bluntschli, $\$ 382$; Calvo, $\$ 734$. 
active assent or silent acquiescence where there must be full knowledge ?'

But if a native chief is not in a position to give jurisdiction over foreigners, why may not that jurisdiction be assumed by a sovereign who annexes the territory so far as not oceupied by the native ehief, but annexes it for eertain limited purposes only, and not so as to make it part of that sovereign's territorial dominions for all purposes?

That there may be such assumption of jurisdietion seems recognized by the article of the Aet of the Berlin Conferenee quoted above ${ }^{2}$, which distinguishes between the protectorate and the possessions.

It is diffieult to see why sovereignty in each case can be acquired by one alone of the above modes, namely, conquest, cession, or oceupation. A strong power may have aequired by conquest one part of certain territory, or a protectorate over certain tribes in it, and the natives of the adjoining part of that territory, or other tribes in it, may yield obedience to that power on aceount of fear without any actual eession. In such a case the sovereignty of the protectorate may be acquired partly by conquest and partly by sufferanee without there being the possibility of determining under which head the acquisition is to be placed.

If, in a region like New Guinea or the eentre of Africa, a British officer enters and assumes control of the territory in the name of the King, either with or without agreements with the tribes dwelling there, is not that to all intents and purposes as mueh a eonquest as if the territory was acquired by the defeat of the former sovereign and the consequent annexation of the country?

We say to foreign Powers, "We hold this territory, and if you attempt to interfere we shall maintain our position with the sword.' How does this differ from conquest? And yet surely there ean be no obligation to assume the internal as wcll as the external sovcreignty.

1 The Laconia, 2 Moo. P. C. (N.S.), 16r.

2. I 76 , note 1 . 
Cн. IX. There appears, therefore, to be nothing contrary to the

The continental view. general principles of international law in what is believed to be the view of other European Powers as to a protectorate in the sense adopted in this chapter, namely, that the entire sovereignty which an independent state possesses is divided between the protector and the protected state; that the protector has the external sovereignty and the responsibilities which belong to it, namely, the responsibility to foreign Powers for injuries committed to their subjects within the protected state; that as regards the internal sovereignty, foreign Powers are not concerned, and therefore have no right to inquire whether the jurisdiction over their subjects within the protected state, so long as it is exercised by a civilized court, is exercised by the protector or by the protected Government.

Objections It is difficult for foreign Powers to object to the exercise by

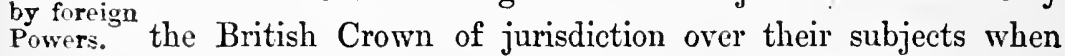
within a protected uncivilized state. By virtue of the protectorate they are excluded from interfering with the protected state. They can only dispute that exclusion in the same way in which they would dispute the sovereignty of the Crown over any part of the British dominions. And by virtue of that exclusion they can only interfere through the British Gorernment with any proceedings against their subjects which are taken in the protected state.

The extent of our responsibility for the natives of protected states when in other states and the amount of protection to be given to subjects of foreign Powers within a protectorate are matters to be decided gradually with the growth of international law on this subject. The latter protection will probably be no greater than what we give to our own subjects, and if foreigners travel or settle, in spite of a warning that they will not be protected, there will be no just complaint against the protecting power for not supporting them.

The extent to which internal sovereignty in the protectorate 
is acquired by the Crown varies with the different protectorates, Cir. IX. and must in each ease be a question of fact ?

Thus, where there are merely native tribes, the chiefs of Extent of which have tribal but no territorial anthority, the amount of $\begin{gathered}\text { sove- } \\ \text { reignty }\end{gathered}$ internal sovereignty aequired by the protector is much larger acquired. than where there is a semi-civilized government, with a snltan or other ruler exereising control within certain territory.

In each ease the internal sovereignty assumed by the protector would be the whole sovereignty of a completely independent state, except what is left to the local Government.

To the extent to which that internal sovereignty is assumed it can be exereised against a foreigner or native as well as against any British subject, including in that term British protected persons who, as in the case of foreign jurisdiction before mentioned ${ }^{2}$, are mainly treated as being in the same position as British subjects.

For the purpose of the exereise of the internal sovereignty, and generally of the exereise of the jurisdietion of the Crown in protectorates, resort has been had to the Foreign Jurisdiction Acts, which were originally passed for different purposes ${ }^{3}$.

The extent of such resort, and the extent to which powers of internal sovereignty have been assumed in Africa, may be gathered from the following summary of the Orders.

In the ease of the territories adjoining the colonies of the Internal Gold Coast, Lagos, Gambia, and Sierra Leone, powers have reiguty is been given to the colonial legislature (subject to disallowance $\begin{gathered}\text { exercised } \\ \text { by Orders }\end{gathered}$ by the King signified through a Secretary of State) to legis- under tho late for giving effect to all jurisdiction of the Crown aequired Jurisdic. in the adjoining territories ${ }^{4}$.

The eharter of the Niger Company, July, $1886^{5}$, authorized

1 In India the power of the British Government over the differont native states (several hundred in number) has to be ascertainod as a fact in each case. Cp. Twiss, § 26 ; Lee Warner, p. 3x, § 13.

2 Seo above, p. 155. SSee above, p. I5I.

- See Stat. K. \& O. Rev. vol. iii. Gold Coast, Dec. 1887, p. 52r ; Lagos, Dec. 1887 , p. 523 ; Gambia, Stut. I. \& O., 1893, p. 31 I ; Sierra Loone, Stat. K. \& O., I895, p. 272.

s Hertslet, Map of Africa by Treaty, vol. i. p. 446. 
CH. IX. the company to retain all powers acquired under the thirtyseven Acts of Cession specified in the schedule for the purposes of government, the preservation of public order, and the protection of the territories. It required the company to fulfil the stipulations of those Acts of Cession, and prohibited the company from transferring their rights under them except with the consent of the Secretary of State. It bound the company to discourage the slave trade, to abstain from interfering with the religion of the inhabitants, and to observe in the administration of justice the customs of any class, tribe, or nation to which the parties belong. It also required the company to comply with any suggestion made by the Secretary of State with reference to the proceedings of the company as regards the inhabitants or foreign Powers or their exercise of rights where there is any adverse claim. It also required the company to comply with any treaty made by the British Crown, and with any directions of the Secretary of State given with reference to it.

The charter followed broadly the lines of the charter given to the North Borneo Company in November, I88I ${ }^{1}$, and the same lines were followed in the charter given to the British South Africa Company in October, I $889^{2}$. But the Borneo charter provided for the exercise of extra-territorial jurisdiction in Borneo by officers appointed by the Crown, and the South Africa charter required all differences with any chief or tribe to be submitted to the Secretary of State for decision, required the company to preserve peace and order and maintain police, and authorized them to make ordinances with the approval of the Secretary of State.

The provisions of the British South Africa Company's charter have been modified to some extent as regards Southern Rhodesia by the Order in Council of $1898^{3}$.

The Africa Order of $1889^{4}$ established for Africa and

1 Hertslet, Commercial Treaties, vol. xv. p. 85 .

${ }^{2}$ London Gazette, Dec. 2o, 1889; Hertslet, Com. Tr. vol. xviii. p. 133 .

${ }^{3}$ Stat. R. \& 0., 1898, p. 385. 'Stat. R. \& O. Rev. vol. iii. p. 259. 
Madagascar a general system to come into force in such areas, Crr. IX. called 'local jurisdictions,' as might be constituted by a Sceretary of State. The Order necessarily did not apply to places within any British possession or the possession of any non-African power or of any other independent state, e. $\mathrm{g}$. Egypt, Morocco, Tunis, Liberia, Orange Free State.

The Order was declared to apply to all British subjects, including British protected subjects and natives ${ }^{1}$ of any other 'local jurisdiction,' and to foreigners who submit themselves to a court in accordance with the Order, and to foreigners with respect to whom any state, king, chief, or government whose subjects they are, has by any treaty agreed with the Crown for, or consented to, the exercise of power or authority by the King. 'Foreigner' in this case includes persons whether natives of Africa or not.

The Orders in Council for protectorates such as those sub- System of ject to the Africa Order of I 889 or the Zanzibar Order of courts in 1897 follow in their structure very largely the Orders in torates, Council for the exercise of foreign jurisdiction in the Ottoman adminisdominions, that is to say, there is a central court held by them. a commissioner or consul-general, with subordinate courts in different districts held by consuls or other inferior officers, with an appeal to the central court, and an appeal from the central court to some court in the British dominions, and an altimate appeal to the King in Council.

These courts have both eivil and criminal jurisdiction, and follow the English law, or on the east side of Africa the Indian law, subjeet in either case to the modifications made by the Order or by regulations made under it.

The Africa Order of 1889 applies some or all of the Acts Africa scheduled to the Foreign Jurisdiction Act, 1890 , such as those relating to fugitive offenders or colonial prisoners. 1889, 1891,

'The Order applies the ordinary criminal law of England, and allows the Secretary of State to apply any law for the time being in force in any British possession in Africa. It

${ }^{1}$ Under the Africa Order, 1893, Stat. I. \& O. (1893), p. 308. 
Сн. IX. also gives the force of law to the provisions of any treaty made by the Crown and applying to any place within the local jurisdiction.

Crimes affecting the personal property of foreigners are to be punishable, with the consent of the foreigners, in the same manner as if they were committed against British subjects.

Every person for the time being holding a commission from the Crown as consul-general, consul, or vice-consul is, if so authorized by a Secretary of State, to hold a consular court in his district, and if the Crown appoints a person not holding such commission to act as judge in any district, he is to have the judicial powers of the consular court ${ }^{1}$.

Appeals are allowed to the Supreme Courts of British possessions in Africa and of Bombay.

The Order, besides applying English criminal law, creates certain new offences; which inclnde levying war against any chief, tribe, or power, acting in contravention of treaties, disturbing any religious ceremony, and smuggling. Further, every consul, if so authorized by a Secretary of State, can make regulations for securing the observance of any treaty or of any native or local law or custom within the district, and also for the peace, order, and good government of British subjects within the district ${ }^{2}$. The regulations, when allowed. by a Secretary of State and published, have effect as if contained in the Order.

In the case of civil suits the Order repeats the provision which is contained in the Ottoman and other Orders respecting foreign jurisdiction in Oriental states requiring a foreigner who sues a British subject to file in the court his own consent, and, if so required, the consent of the competent

1 For the purpose of the Capitulations in Turkey it was necessary that every person exercising any judicial jurisdiction should be a consul. This reason does not apply in places where the Capitulations do not extend ; and in many of those places the terms 'consul' and 'consular' court' are inapplicable, not to say misleading. See above, p. I 72.

2 The words 'peace, order, and good government,' are the traditional words by which the widest powers of legislation have been given to colonial Governments. 
authority of his own Government, to sulmmit to the jurisdiction ${ }^{*}$ Cr. IX. of the court.

By the Africa Orders of I $89 I_{1}{ }^{1}$, which apply to the Bechuanaland protectorate, i.e. the territories in South Africa bounded by British Bechnanaland, the German protectorates, the rivers Chobe and Zambesi, the Portuguese possessions, and the late South African Republic, the High Commissioner was authorized by proclamation to provide for the administration of justice, the raising of revenue, and generally for the peace, order, and good government of all persons within the limits of the Order, including the prohibition and punishment of acts tending to disturb the public peace. The High Commissioner in issuing such proclamation was to respect any native laws or customs by which the civil relations of any native chiefs, tribes, or populations under Her Majesty's protection were at the date of the Order regulated, except so far as the same might be incompatible with the due exercise of Her Majesty's power and jurisdiction. Any such proclamation can be disallowed by the Crom through a Secretary of State, precisely as if it were an ordinance of a British colony.

The Africa Order of $1892^{2}$ recited that by the General Act of the Conference of Berlin, signed in 1885 , the Signatory Powers declared with respect to oceupation in Africa by any of those Powers that the establishment of authority in protected territories was an obligation resting upon the respective protecting Powers; and that in order to the due fulfilment of the said obligation as respects any of the territories within the limits of the Africa Order of 1889 which Her Majesty had declared to be under IIer protection, it was necessary that the subjects of the Signatory Powers should be justiciable under the Order in like manner as British subjects. The Order then ordained that where Her Majesty had declared any place within the above limits to be a protectorate of Her Majesty the provisions of the Order of 1889 , which referred to British

\footnotetext{
1 Stat. Li. \& O. (189r), pp. 295, 298.

2. Stat. R. \&. O. (1892), p. 486 .
} 
Cr. IX. subjects (except those relating to registration), should extend to all foreigners who were subjects of any of the above Signatory Powers or of any other Power which had consented that its subjects should be justiciable under the Order of I 889 . And so much of the Order as required the consent of the foreigner as a condition of the exercise of jurisdiction was to be of no force as respected foreigners to whom the Order so applied.

The same Order also enabled the Secretary of State to apply to any place within the Order of 1889 any Act in force in British India.

This Order therefore, as respects any place in Africa thus declared to be a protectorate, brings all foreigners who are subjects of the above Powers within the criminal law enacted by the Order of 1889 for British subjects, and within the legislative powers given to the High Commissioner by the Order of I 891 and to the Secretary of State by the Order of 1892.

The declaration has been made as respects the following protectorates :-

East Africa,

Bechuanaland,

Southern Rhodesia,
Uganda,

British Central Africa,

Niger Coast.

Under the Order of 1892 the Indian Land Acquisition Act of 1894 was applied to the Uganda protectorate, and by a subsequent Order of July, J898 ${ }^{1}$, any lands taken under the Order for public purposes are ordered to vest in the commissioner and consul-general, or, if the Secretary of State so lirects, in trustees.

Amaton- The Amatongaland Order of June, I $896^{2}$, provided that galand Order. the special commissioner, who in fact was also governor of Natal, might on behalf of the Crown, by proclamation, provide for the administration of justice, the raising of revenues, and, generally, for the peace, order, and good government of all persons within the limits of the Order. The

1 Stat. R. \& 0., 1898, p. 382 .

' Stat.R. \& 0., I896, p. 117 . 
proclamation was to take effect until disallowed by the Qneen through a Secretary of State, and to give the courts of Zululand the same jurisdiction, civil and criminal, as they might possess from time to time in respect of matters occuring within Zululand. The Order ceased to operate upon Amatongaland being in 1897 made part of the British dominions and annexed to the colony of Natal.

The East Africa Orler, I $897^{1}$, applies to foreigners, in Eart so far as the Crown by treaty; grants, usage, sufferance, or Order:, other lawful means has jurisdiction in relation to them. But ${ }^{\text {1897, I898. }}$ where foreigners in the Zanzibar territory are subjects of any Govermment which on July I, I 895, exercised any jurisdiction in that territory similar to the jurisdiction conferred by the Order, the Order does not apply unless that Government consent.

The Order applies the law of British India to the persons subject to the Order, and enables the Secretary of State to declare that any of the laws for the time being in foree in any African possession of the King shall have effect in the protectorate.

A foreigner subject to the Order can be prosecuted criminally and sued civilly as a defendant.

The procedure in eivil and criminal cases is to follow the Indian law.

The chief authority is rested in a commissioner appointed by the King:, but the court is held by a judicial officer appointed by the King under His Sign Manual.

Among other Indian laws applied by this Order was the Land Aequisition Act, 1894 , which authorized the aequisition of land for public purposes, and by a subsequent Order of July, I 898 ", provision was made for land so taken vesting in the commissioner and consul-general and their successors in office, or, if the Secretary of State so directed, in trustees.

1 Stat. R. \& 0., :897, p. 134 .

2 At present tho person who is agent and consul-general at Zanzibar.

: Stat. R.\& $0 ., \mathbf{1} 898$, p. 38 r. 
Cr. IX. The East Africa Order of $1898^{1}$ regulated the currency of the East African protectorate, making the silver rupee the standard coin, prohibiting other eoins, and declaring what should be legal tender.

Zanzibar The Zanzibar Order of $1897^{2}$ is made to extend to foreigners with respeet to whom the Government whose subjects they are has by treaty or otlierwise agreed with the King for, or consented to, the exercise of power or authority by His Majesty. The Order makes eertain acts criminal when done by persons subject to the Order, and provides for the eriminal prosecution of a eivil suit against every such person.

Natives of Zanzibar are not such persons, but all civil disputes between them and such persons are to be heard by the court under the Order.

The consul-general has porver to legislate for persons subject to the Order.

Matabele- The Matabeleland Order of $1894^{3}$, after reciting that the land Order. area there described is under the protection of the British Crown, entrusts the administration of the area to the British South Africa Company, with a provision that the powers given by the Order to the eompany are to be in addition to the power given by its eharter, but are to be exercised only concurrently with the High Commissioner.

The Order establishes a land commission, with power to deal with the settlement of the natives on eertain areas of land, subject to the reservation of mineral rights, and with power to expropriate those natives for certain purposes on giving them equivalent land. This provision was rescinded but in Southern substance re-enacted by the Southern Rhodesia Order, $1898^{4}$, Rhodesia order. which further legislates for the conditions under which a native may acquire and dispose of land.

This last-mentioned Order differs from the other Orders, inasmuch as it confers the administration of the protectorate

${ }^{1}$ Stat. $R . \&$ O., I898, No. 409, p. $376 . \quad 2$ Stat. R. \& O., 1897, p. 159.
${ }^{3}$ Stat. R. \& O., 1894, p. 133. 
upon the British South Africa Company, although it gives CH. IX. that power only concurrently with the power of the High Commissioner.

The manner in which the administration is to be effected is laid down by requiring the eompany to appoint an administrator or administrators, and authorizing the Secretary of State to appoint an officer, to be called Resident Commissioner, who is to represent the Crown and is to report to the High Commissioner.

The Order establishes a legislative body, consisting of the Administrator, the Resident Commissioner, and nine other nominated members appointed by the company with the approval of the Secretary of State, and four members elected by the registered roters. The Administrator, with the advice and consent of the legislative council, is authorized to make ordinances for the peace, order, and good government of Southern Rhodesia, but no ordinance takes effect until the High Commissioner has signified his assent thereto; and the ordinance can be disallowed within one year by a Secretary of State.

The Order provides for the maintenance of certain control over the finances, for excluding differential customs duties, for the maintenance of military police, for the establishment of a court of record and of magistrates, and for the establishment of a department to manage native affairs.

It will be seen that the Orders in Council have in faet Great exexercised powers of internal sovereignty in the protectorates tent of not merely for the purpose of foreion relations or of police exercised i. e. of keeping the peace and preventing disorder, but for Orders. many legislative and judicial purposes.

They have provided for the coinage, for the establishment of a legislative authority, for the acquisition of land for public purposes, for the settlehent of natives upon particular areas of land, and for giving titles to land ${ }^{\text {. }}$.

\footnotetext{
'Article 83 of the Southern Rhodesia Order of 1898 anthorizes a nativo to acquire and dispose of land on the same conditions as a person who is
} 
Crr. IX. As the power has been used to create legislative bodics, it apparently might apply to the creation of municipalities and to any subject of internal government.

How far such extensions can be made without the protectorate becoming part of the dominions of the Crown and ceasing to be a mere protectorate, is a question which may admit of some argument. It might no doubt be extremely inconvenient that all the natives who are inhabitants of the protectorate should become British subjects for all purposes; but this does not help the difficulty of distinguishing between a protectorate and a British possession where the whole legislative and administrative power in the protectorate is almost identical with that which is found in some of the British possessions.

All that need be noted here is the fact that in the African protectorates, where there are only uncivilized tribes, the amount of internal sovereignty assumed by the protector has been very large, especially where the sovereign power has been given to or assumed by a chartered company.

As the power has bcen used to create legislative bodies, there seems no limit to the extent to which it can be used. In fact, almost as much power has been excreised as can be exercised over conquered territory which is part of the British dominions.

Where so much power has been exercised it seems difficult to draw the line between a protectorate and a British possession. If the whole sovereignty is assumed the territory is really part of the dominions. Apparently the only difference is that in a British possession responsibility is assumed for the whole of the internal government, i. e. for the government of the natives of the protected states inter se, and, further, all those natives become British subjects wherever they may be. A further consequence of the territory becoming part of the

not a native, subject to certain restrictions. This provision implies that persons not natives can acquire and dispose of land in a particular manner without these restrictions. 
British dominions would be that English law would prima Crr. IX. facie apply, though the consequenee ean be avoided by the provisions of an Order in Couneil exeluding it.

It will be observed that the Orders show a gradual inerease of the assumption of internal sovereignty. The Afriea Order of 1889 applied only to British subjeets, and contained the provisions inserted in the foreign jurisdietion Orders applicable to the Ottoman and other dominions, which require the consent of the Government of a foreiguer to the exereise of jurisdiction.

The Order of 1892 as regards any place deelared to be within the protection of the British Crown extended to all subjects of those Powers who had signed the Act of Berlin or had otherwise assented to or acquieseed in the assumption of jurisdiction by the Crown. Thus in effect, the provisions of the Order of 1892 relating to British subjects applied, as the Order of $\mathrm{I} 889$ did not, the criminal law to foreigners. The East Africa Order of 1889 and the Rhodesia Order of I 898 apply apparently to all persons, whether British subjeets or foreigners.

On what legal basis do these Orders rest? By international Legal law, if the above arguments are sound, the Crown, even in the basis, absence of express treaty, usage, or consent, might have tional and jurisdiction within a protectorate over foreigners, including pal, of Europeans who are not British subjects. Further, the Powers Orders. who signed the Berlin and Brussels Acts must be held to have consented to or aequiesced in that doctrine, and therefore in the exercise of jurisdiction by the British Crown over their subjects when within a British protectorate.

Do they rest in fact upon treaty?

As a matter of fact treaties have often been made with the native tribes within a protectorate. Thus in the territories of the Niger Company 343 treaties were made by the eompany and approved by the Seeretary of State. These treaties were in different forms. In most eases they were in form a concession by the tribe of territory to the company, 
Сн. IX. with the right of exchding foreigners, and with an undertaking by the company to protect the tribe, and not to take land without compensation, nor to interfere with native law ${ }^{\mathbf{l}}$. Many, if not all, of these treaties specify the bounds of the territory of the tribe; but some doubt must of course arise as to whether the bounds so stated cover the whole of the territories formerly under the company.

In British South Africa some treaties have also been made, but these treaties do not cover the whole of the territory, and indeed a portion of the territory is believed to be withont any natives. Further, a considerable part of the territory must be considered to have been acquired by conquest. Internationally there may be no difficulty as regards the territories not within any of these treaties; and as regards the treaties themselves it must be open to considerable doubt whether a convention with a half-savage tribe or its chief can be considered to be a treaty conferring jurisdiction.

It must now be considered on what municipal law the Orders in Council regulating the protectorates in such cases rest, and what authority there is to govern British subjects and foreigners within them.

The Forcign Jurisdiction Act, as before mentioned, does not confer jurisdiction on the Crown, but merely enables the Crown to exercise jurisdiction obtained ab extra. It is also doubtful whether it applies where the jurisdiction is acquired by conquest or there is cession of territory.

Even where it applies it cannot be said to be perfectly clear that section I of the Act, enabling the Crown to exercise the jurisdiction, applies to other than British subjects. Section 2 of the Act, which extends to cases where there is no Government capable of entering into a treaty, and which therefore seems peculiarly applicable to Africa, is expressly limited to British subjects. But this section appears to apply to British subjects in places where there is no protectorate. All the Orders in Council profess to proceed on

\footnotetext{
1 Hertslet, Map of Africa by Treaty, vol. i. p. 457.
} 
section I of the Act and upon any other powers enabling the Св. IX. Queen in that behalf.

The charters granted to the Niger Company and the British South Africa Company enabled the companies to exercise the jurisdiction which they are recited in the charter to have already obtained by the treaties or which they may hereafter obtain.

It seems that the municipal law under which the jurisdiction is exercised must partly be based on the common law power of the Crown. The power of the Crown at common law to legislate by Order in Council or by charter for any conquered territory is undoubted, and it must be presumed that the Crown has the same power as respects any portion of sovereignty acquired in the same manner, although it may not be the entire sovereignty.

But in places where there are no natives and to which British subjects resort a difficulty may arise under the constitutional doctrine as to British settlements, namely, that where there is a British settlement the Crown can establish a legislature, but cannot legislate itself.

In the case of the chartered companies in Africa, and in the case of the chartered company and the Rajah of Sarawak in Borneo, there is a curious conflict between two constitutional doctrines. One doctrine is that no addition can be made to the dominions of the Crown without the consent of the Crown. The other is that any sovereignty acquired by a British subject is acquired on behalf of the British Crown. When therefore the Niger Company and the British South Africa Company have taken from native tribes or chiefs a cession of territory, that must, according to the second of the two doctrines, be deemed to be a cession of territory acquired on behalf of the Crown, and yet it is treated as an independent state under the protection but not within the dominions of the Crown. And the same is the ease with the North Borneo Company and the Rajalı of Sarawak.

A few words should be added as to the Indian protectorates. 
Сн. IX. They began with treaties under which certain jurisdiction was

Indian protectorates. ceded to the East India Company. But as the British Crown has become the paramount power in India, and has, partly by succession to the Mogul and partly by conquest, acquired the suzerainty over the native states in India, the protectorates depend now upon orders of the governor-general and less upon the treaties.

The extent to which the internal sovereignty has been acquired differs very largely and has to be ascertained as a matter of fact in each case.

The juriscliction is exercised by the governor-general and the executive council as representing the Crown. The Indian legislature has no power to legislate for the exercise of such jurisdiction, except so far as enabled to do so by its power to legislate for all natives of British India and for all European British subjects whenever they are in the native states of India. It may be observed that the Indian legislature has no power to legislate for British subjects who are neither Europeans nor natives of British India, and still less for foreigners in an Indian protected state.

But the Governor-General in Council by virtue of his commission as viceroy exercises the jurisdiction of the Crown in these native states, and in that capacity legislates for offences committed within them by British subjects who are neither native nor European, and, where the jurisdiction is delegated or transferred by the protected state, for foreigners.

The jurisdiction may be acquired not merely over a special class of persons in the ordinary part of the state, but over all persons in certain areas, e.g. military cantonments or railways, the jurisdiction over which has been transferred by the native sovereign to the Government of India.

Territories held by Europeans in India, e. g. the French or Portuguese, to which the suzerainty of the British Crown does not extend, are in the same position as ordinary European states. 


\section{APPENDIX II}

\section{NON-SELF-GOVERNING COLONIES}

I. Colonies having a representative assembly, i. o. an assembly Apr. II. all or a majority of whose members are elected by the people:

${ }^{2}$ Bahama Islands

${ }^{3}$ Barbadoes

${ }^{1}$ Bermuda

British Guiana
${ }^{1}$ Jamaica ${ }^{2}$

${ }^{1}$ Leeward Islands (central council) ${ }^{2}$

Malta

II. Colonies not having such a representative assembly.

(a) Having a legislative council with, except where otherwise stated, an official majority:

${ }^{3}$ British Honduras ${ }^{3}$

British New Guinea

Ceylon

Falkland Islands

Fiji ${ }^{4}$

Gambia

Gold Coast

Hong-Kong

Lagos $^{4}$

Leevard Islands (local councils) viz. Antigua ${ }^{4}$

St. Kitts and Novis ${ }^{4}$

Dominica ${ }^{4}$

Montserrat

Virgin Islands

Mauritius
Seychelles
Sierra Leone
Straits Settlements ${ }^{6}$
Trinidad and Tobago
Windward Islands
viz. Grenada
St. Lucia
St. Vincent
Turks and Caicos
T-

1 Power not reserved to the Queen in Council to legislate.

2 The governor can nominate enough to place the elected members in a minority of one.

${ }^{3}$ Majority of council uon-official, but nominees of governor.

1 Ifalf of members official, half non-official nomineus.

"Somo of members are elected.

- There is a governor-in-chief, but no central legislative council.

7 Council subordinato to legislaturo of Jamaica. 
Apr. II.

(b) Not having a legislative council :

Basutoland

Labuan

Gibraltar

St. Helena

NoтE.-The Queen in Council can legislate for the constitution of Jamaica under $29 \& 30$ Vict. c. 12 ; of Grenada under 39 $\& 40$ Vict. c. 47 ; and can legislate generally for the Straits Settlements under $29 \& 30$ Vict. c. II5.

See some of the colonial constitutions in Stat. $R$. and $O$. Rev. vol. viii. p. $3^{80}$ et seq., and in Stat. R. and O., Appendix to 1895 and other vols. For legislatures and executives in 1888 and instrument of constitution, see Parl. P., I889, No. 70, vol. lv. P. 7I ; and I8go, No. 194, vol. xlix. p. I. 


\title{
APPENDIX III
}

\author{
BRITISH NORTH AMERICA ACT, 1867 \\ (30 \& 3 I Vict. c. 3) \\ SECTIONS 91 To 95.
}

Distribution of Legislative Powers.

Poucers of the Parliament.

Section 91. It shall be lawful for the Queen, by and with the advice and consent of the Senate and House of Commons, to make laws for the peace, order, and good government of Canada, in relation to all matters not coming within the classes of subjects by this Act assigned exclusively to the Legislatures of Apr. III. the provinces; and for greater certainty, but not so as to restrict the generality of the foregoing terms of this section, it is hereby declared that (notwithstanding anything in this Act) the exclusive legislative authority of the Parliament of Canada extends to all matters coming within the classes of subjects next hereinafter enumerated; that is to say-

I. The public debt and property.

2. The regulation of trade and commerce.

3. The raising of money by any mode or system of taxation.

4. The borrowing of money on the public credit.

5. Postal service.

6. The census and statisties.

7. Militia, military and naval service, and defence.

8. The fixing of and providing for the salaries and allowances of civil and other officers of the Government of Canada.

9. Beacons, buoys, lighthouses, and Sable Island.

ı. Navigation and shipping.

Ir. Quarantine and the establishment and maintenance of marine hospitals.

12. Sea coast and inland fisheries.

13. Ferries between a province and any British or foreign country or between two provinces.

14. Currency and coinage. 
APP. III. I5. Banking, incorporation of banks, and the issue of paper money.

I6. Savings banks.

17. Weights and measures.

18. Bills of exchange and promissory notes.

I9. Interest.

20. Legal tender.

2I. Bankruptey and insolvency.

22. Patents of invention and discovery.

23. Copyrights.

24. Indians, and lands reserved for the Indians.

25. Naturalization and aliens.

26. Marriage and divorce.

27. The criminal law, except the constitution of courts of criminal jurisdiction, but including the procedure in criminal matters.

28. The establishment, maintenance, and management of penitentiaries.

29. Such classes of subjects as are expressly excepted in the enumeration of the classes of subjects by this Act assigned exclusively to the Legislatures of the provinces.

And any matter coming within any of the classes of subjects enumerated in this section shall not be deemed to come within the class of matters of a local or private nature comprised in the enumeration of the classes of subjects by this Act assigned exclusively to the Legislatures of the provinces.

\section{Exclusive Powers of Protincial Legislatures.}

Subjects of exclusive provincia] legislation.
Section 92. In each province the Legislature may exclusively make laws in relation to matters coming within the classes of subjects next hereinafter enumerated ; that is to say-

I. The amendment from time to time, notwithstanding anything in this Act, of the constitution of the province, except as regards the office of Lieutenant-Governor.

2. Direct taxation within the province in order to the raising of a revenue for provincial purposes.

3. The borrowing of money on the sole credit of the provinee.

4. The establishment and tenure of provincial offices and the appointment and payment of provincial officers.

5. The management and sale of the public lands belonging to the province and of the timber and wood thereon.

6. The establishment, maintenance, and management of public and reformatory prisons in and for the province.

7. The establishment, maintenance, and management of hospitals, asylums, charities, and eleemosynary institu- 
tions in and for the province, other than marine Arr. III. hospitals.

8. Mínicipal institutions in the province.

9. Shop, saloon, tavern, auctioneer, and other licences in order to the raising of a revenue for provincial, local, or municipal purposes.

Io. Local works and undertakings other than such as are of the following classes:--

a. Lines of steam or other ships, railways, canals, telegraphs, and other works and undertakings connecting the province with any other or others of the provinces, or extending beyond the limits of the province:

$b$. Lines of steam ships between the province and any British or foreign country :

c. Such works as, although wholly situate within the province, are before or after their execntion declared by the Parliament of Canada to be for the general advantage of Canada or for the advantage of two or more of the provinces.

II. The incorporation of companies with provincial objects.

12. The solemnization of marriage in the province.

I3. Property and eivil rights in the province.

I4. The administration of justice in the province, including the constitution, maintenance, and organization of provineial courts, both of eivil and criminal jurisdiction, and incluciing procedure in eivil matters in those courts.

15. The imposition of punishment by fine, penalty, or imprisonment for enforcing any law of the province made in relation to any matter coming within any of the classes of subjects enumerited in this section.

16. Generally all matters of a merely local or private nature in the province.

\section{Education.}

Section 93. In and for each province the Legislature may Legislation axclusively make laws in relation to education, subject and according to the following provisions :-

(I) Nothing in any such law shall prejudicially affect any right or privilege with respect to denominational schools which any class of persons have by liw in the province at the union :

(2) All the powers, privileges, and duties at the union by law conferred and imposed in Upper Canada on the separate schools and school trustees of the Queen's Roman Catholic subjects shall be and the same are hereby extended to the 
Apr. III. dissentient schools of the Queen's Protestant and Roman Catholic subjects in Quebec:

(3) Where in any province a system of separate or dissentient schools exists by law at the union or is thereafter established by the Legislature of the province, an appeal shall lie to the Governor-General in Council from any Act or decision of any provincial authority affecting any right or privilege of the Protestant or Roman Catholic minority of the Queen's subjects in relation to education:

(4) In case any such provincial law as from time to time seems to the Governor-General in Council requisite for the due execution of the provisions of this section is not made, or in case any decision of the Governor-General in Council on any appeal under this section is not duly executed by the proper. provincial authority in that behalf, then and in every such case, and as far only as the circumstances of each case require, the Parliament of Canada may make remedial laws for the due execution of the provisions of this section and of any decision of the Governor-General in Council under this section.

\section{Uniformity of Laws in Ontario, Nora Scotia, and New Brunswick.}

Legislation for uniformity of laws in three provinces.

Concurrent powers of Legislature respecting agriculture and inmigra. tion.
Section 94. Notwithstanding anything in this Act, the Parliament of Canada may make provision for the uniformity of all or any of the laws relative to property and civil rights in Ontario, Nova Scotia, and New Brunswick, and of the procedure of all or any of the courts in those three provinces, and from and after the passing of any Act in that behalf the power of the Parliament of Canada to make laws in relation to any matter comprised in any such Act shall, notwithstanding anything in this Act, be unrestricted; but any Act of the Parliament of Canada making provision for such uniformity shall not have effect in any province unless and until it is adopted and enacted as law by the Legislature thereof.

\section{Agriculturc and Inmigration.}

Section 95. In each province the Legislature may make laws in relation to agriculture in the province, and to immigration into the province; and it is hereby declared that the Parliament of Canada may from time to time make laws in relation to agriculture in all or any of the provinces, and to immigration into all or any of the provinces; and any law of the Legislature of a province relative to agriculture or to immigration shall have effect in and for the province as long and as far only as it is not repugnant to any Act of the Parliament of Canada. 


\section{JUDICIAL CONSTRUCTION OF THE ABOVE SECTIONS.}

Apr. III.

According to the ordinary rules of law, any Act passed by the Dominion Parliament on a matter which s. 92 of the British North America Act places within the exclusive legislative authority of the Provincial Legislature, and on the other hand any Act passed by the Provincial Legislature which is not witlin the authority conferred by s. 92 is ultra vires and void. And the validity of the Act can be raised in and determined by any court which has to deal with a case affected by the Act ${ }^{1}$.

Various decisions therefore on the valiclity of Acts, both of the Dominion Parliament and the Provincial Legislatures, have been given by the Judicial Committee of the Privy Comcil, and still more by the Canadian courts, both those of the provinces and the Supreme Court of Canada 2 .

The decisions, especially those of the Julicial Committee, have laid down such clear principles that the appeals to the Queen in Council touching the validity of any Act have, of late years, been comparatively few.

The principles laid down are as follows :-

The Courts of Canada have decided that 'exclusive in ss. 91 and 92 refers solely to the division of legislative powers between the Dominion Parliament and the Provincial Legislatures, and does not affect the power of the Imperial Parliament ${ }^{3}$.

The Judicial Committee has laid down that the legislative powers conferred both on the Dominion Parliament and the Provincial Legislature are plenary and not delegated powers, that therefore the principle of delegatus delegare non potest does not apply, and that although the limits of legislation are prescribed, yet within those linits the right of legislation is absolute, and the Local Legislature is supreme, and has the sameauthority as the Imperial Parliament to give a municipal body power to make by-laws ${ }^{4}$.

The Judicial Committee also refused to entertilin an argument derived from the possible abuse of power by the Provincial Legislature, saying that 'they could not conceive that when the Inperial Parliament conferred wide powers of local government

1 See Pope r. Grifith, 2 Cart. 29 r (Q. T., Que.)

"Collected in Cartwright's cases on British Forth Ameriea Aet, 4 vols. (1882-92). Some illustrative cases are briefly stated below.

${ }^{3}$ Smiles v. Belford, 1 Cart. 576 (Ct. of $\Lambda$ pP., Ont.) ; $R$. v. Coll. of Phys. and Surgs., Ontario, 1 Cart. 76 I (Q. B.. Ont.).

'Hodye v. The Queen, I.R. 9 A.C. I17. See also R. v. Bureth, L.R. 3 A.C. 889 as to India ; and re Goodhue, I Cart. 560 (Ct. of $\Lambda$ pp., Oni.). Powell $\checkmark$. Apollo randle Co., L. I. 10 A.C. 282. See also Phillips v. Eyre, I. R. 6 Q. B. I. 
Apr. III. on great countries such as Quebec, it intended to limit them on the speculation that they would be used in an injurious manner' ; and again 'to place a limit on it' (the legitimate meaning of subss. (2) and (9) of s. 92), 'because the power may be used unwisely, as all powers may, ould be an error'".

The Act exhausts the whole range of legislative power, and whatever is not given to the Provincial Legislature rests with the Dominion Parliament 2 .

[The general authority given by the introductory enactments of s. 91 to the Canadian Parliament 'to make laws for the peace, order, and good government of Canada' will be strictly confined to such matters as are unquestionably of Canadian interest and importance; and the exception in the concluding words of the section has no application to those matters ${ }^{3}$.]

The powers of legislation conferred by ss. 91 and 92 are to a certain extent concurrent and conflicting. But as it could not have been intended that the powers exclusively assigned to the Provincial Legislature (s. 92) should be absorbed in those given to the Dominion Parliament (s. 91), it is necessary in each case to ascertain in what degree and to what extent authority to deal with matters falling within each class of subjects exists in each Legislature, and to define in a particular case the limits of their respective powers. It could not have been the intention that a conflict should exist, and in order to prevent such a result the two sections must be read together, and the language of one interpreted and, where necessary, modified by that of the other. As respects certain matters falling within the general description of subjects in s. 91, legislative power may reside in a Provincial Legislature.

Each question should be determined on its own merits 4

Subjects which in one aspect and for one purpose fall within s. 92 may in another aspect and for another purpose fall within s. $91^{5}$.

Where the validity of an Act of the Provincial Legislature is impeached, the first question to be decided is whether the Act falls within any of the classes of subjects enumerated in s. 92, for, if it does not, the Act is invalid, and no other question arises. If it does fall prima facie within one of those classes of subjects, the further question arises whether it does not also fall

1 Bank of Toronto v. Lambe, L. R. I2 A. C. 575.

2 Bank of Toronto v. Lambe, L. R. I2 A. C. 588.

[ ${ }^{3}$ Attorney-General for Ontario v. Attorney-General for the Dominion, L. R. [1896] A. C. 348 .]

t Citizens' Insurance Compeny of Canada v. Persons, L. R. 7 A. C. 96. See also Hodge v. The Queen, L. R. 9 A. C. 128.

5 Hodge v. The Qietn, L. R. 9 A. C. 117. 
within the class of subjects enumerated in s. 91, and whether the power of the Provincial Legislature is or is not thereby overborne ?.

Apparently, where an Act of the Dominion Parliament is impeached, a similar course would be adopted.

For instance, the power of the Dominion Parliament (s. 91 (2)) to legislate for the regulation of trade and commerce conflicts to a certain extent with the power of the Provincial Legislature (s. 92 (13) to legislate for property and civil rights.

The principle is that each Legislature when legislatin on the subject assigned to it, may pass such Act as is necessary for giving effect to the legislation, even though the Act touches incidentally a subject not assigned to the Legislature passing it $^{2}$. And s. 91 refers only to general legislation.

Thus an Act of the Dominion Parliament for the general regulation of trade may deal with property and eivil rights so far as is incidental to earrying into effect the regulation of trade.

And a statute of a Provincial Legislature dealing with 'property and civil rights' is ralid though it incidentally affects trade.

Again, a Dominion Act may for the purpose of maintaining law and order, or of regulating the trade in liquor throughout the Dominion, prohibit the sale of liquor in any town which adopts the Act, notwithstanding that such a provision affects the powers of the Provincial Legislature under s. 92 (9) as to tarem licences, and s. 92 (13) as to property and eivil rights.

A Provincial Legislature, on the other hand, can authorize a municipality to make by-laws regulating the liquor traffic, so long as they are not contrary to the Dominion Act.

And a Provincial Act may fix the qualifieation for (say) a chemist to carry on his business, or regulate the sale of goods in streets, though such enactments may affec trade.

The power of the Dominion Parliament under s. 91 (12) to regulate fisheries does not authorize legislation as to private property in fisheries, which is exchusively under the Provineial Legislature (s. 92 (13)).

The power of the Dominion Parliament to raise money by any mode of taxation (s. 91 (3)) is limited by s. 92 (2), so that the Dominion Parliament cannot provide for direct taxation within

'Citizens' Insurance Company of Cenala v. Persons, L. R. 7 A. C. 108, 109; Dobio v. Temporalities Biorel. L. R. 7 A. C. 149 ; Russell v. The Queen, L. R. 7 A. C. 829 ; Bank of Toronto v. Lombe, I. R. I2 A. C. 58 I.

${ }^{2}$ Iiussell v. Iieg., L. I. 7 A.C. 839 ; Bennett v. Phamaceutical Association of Quebcc, 2 Cart. 250 (Q. L.. Que.). 
Apr. III. a province in order to the raising of a revenue for provincial purposes.

On the other hand, the Provincial Legislature being limited to direct taxation, cannot, for the purpose of provincial revenue, impose a licence or stamp duty, nor tax the salaries of officers of the Dominion Government.

But that Legislature can impose direct taxation upon banks and insurance companies carrying on business in the province, although they are domiciled and have their principal offices outside the province, and may impose direct taxation for local purposes, e. g., those of a municipality and not merely for the purpose of the whole province.

And apparently a Provincial Legislature can under s. 92 (8) authorize a municipality to charge for licences to shops, \&c., where the object is not to raise a revenue for provincial purposes.

The Dominion Parliament alone can incorporate a company to carry on business in more than one province, and a company so incorporated need not in fact carry on business in more than one province, but it is subject to the law of the province respecting the mode in which business may be carried on in that province.

A Provincial Legislature can incorporate a company for making navigation; but its powers are limited to the province (s. 92 (ro)).

Although the Dominion Parliament, under s. 91 (27), can exclusively legislate for criminal law and criminal procedure, a Provincial Legislature, under s. 92 (I5), can not only impose punishment by fine or imprisonment (and that with or without hard labour) for any offence against an Act which that Legislature has power to pass, but can also regulate the procedure for such offence so long as it is purely an offence against the provincial Act, and not an offence by the general law of the dominion.

If it is an offence by the general law, the punishment or procedure cannot be altered by the Provincial Legislature even though it is also made an offence against the provincial statute.

Nor can the Provincial Legislature alter the general rules as to evidence in criminal matters, as e. g. by allowing a defendant to be forced to criminate himself.

\section{ILLUSTRATIVE CASES DECIDED ON ABOVE SECTIONS.}


concerns, and perhaps to general regulations affecting the whole APr. III. dominion, but does not include the regulation of contracts relating to a particular business or trade in one province. That is within s. 92 (13).

Thus an Ontario Act, preseribing conditions which are to form part of every policy of fire insurance entered into or in force in the province for insuring property situate therein against fire, is valid, and applies to the contracts of all insurers in Ontario, including corporations incorporated by imperial Act, or by foreign or colonial authority. Citizens' Insuranee Company v. Parsons, L. R. 7 A. C. 96.

[But power to regulate does not mean power to prohibit. Attorney-General for Ontario v. Attorney-General for Canada, L. R. [1896] A. C. 348.]

Section 91 (2) does not prevent the Provincial Legislature dealing with licences under s. 92 (9). Severn v. The Queen, I Cart. 4r4 (Sup. Ct. of Can.); Regina v. Boardman, I Cart. 676 (Q. B., Ont.), nor with regulations for good order which affect the liquor traffic. Hodge v. The Queen, L. R. 9 A. C. II 7.

A Dominion Act authorizing transfer of warehouse receipts to banks by direct endersement was held valid under s. 91 (2) or ( $\left.\mathrm{r}_{5}\right)$, notwithstanding s. 92 (13), because the Dominion Parliament can legislate as to property and civil rights, so far as necessary for its power over subjects in s. 91. Smith v. Merchants' Bank, I Cart. 828 (Ct. of Ch., Ont.).

'Property' and 'civil rights' are used in their largest sense, and 'civil rights' include rights arising from contract, and do not mean only such rights as flowed from the law, e.g. the status of persons. 'Civil rights' are not included in express terms in s. 91. Citizens' Insurance Company of Canada v. Parsons, L. R. 7 A. C. rio.

A provincial Act respecting the debts of a railway company in the province, being debts arising under a local Act, is valid under s. 92 (13), although the creditor was in England, and therefore the debt domiciled in England. Jones v. Canadu Central Railuay Company, I Cart. 777 (Q. B., Ont.).

A previncial Act providing for the effect of a bill of lading is valid under s. 92 (13), and is not an interference with trade, s. 91 (2). Beard v. Steele, I Cart. 683 (Q. B., Ont.).

A Provincial Legislature can settle the qualifications of persons to manage a business, although the doing se affects trade indirectly. The qualification to carry on a trade, e.g. to be a chemist, is a civil right, and is within s. 92 (13), and not within s. 91 (2). Bennett v. Pharmaceutical Socicty of Quebec, 2 Cart. 250 (Q. B., Que.).

A Dominion Act providing for tho disposal in a county court 
Apr. III. of claims by and against assignees in insolvency is valid under s. 91 (21). Crombie v. Jaclison, I Cart. 685 (Q. B., Ont.).

S. $91(21)$. Bankruptey and insolvency.

This decision was supported on the ground that a similar law was in force at the passing of the Act, a course followed in Corporation of Three Iiivers v. Sulte, 2 Cart. 280 (Q. B., Q ue.), but on this point see the dissent of the Judicial Committee (in Banz: of Toronto v. Lambe, L. R. I2 A. C. $5^{87}$ ) from the suggestion that the Provincial Legislatures possess power of legislation either inherent in them or dating from the time of the Federation Act, and not taken away by that Act.

The Dominion Parliament, by s. 91 (2r), has power to interfere with property and civil rights and procedure so far as they might be affected by a general law relating to bankruptcy. Consequently a Dominion Act, providing that a judgement of a court of appeal in bankruptcy matters should be final, was valid. Cushing $\mathrm{r}$. Dupuy, L. R. 5 A. C. 409.

Regulation: of trade in liquors.

A Dominion Act enabling towns to adopt those provisions of it which prohibit the sale of liquor, held valid because it is not within s. 92 (9), (I3), or ( 16 ), and as relating to the peace, order, and good govermment of Canada, but not as regulating trade and commerce.

It is not within subs. (9), because that subsection is limited to licences for revenue, and legislation interfering with the sale of articles mentioned in subs. (9) is not legislation on the subjects specified in subs. (9).

It is not within subs. (I3), because that Act primarily relates to public order and safety, and only secondarily to civil rights.

It is not of a local nature within subs. (I6), because, although it may only be adopted in certain localities, it is a uniform law for promoting temperance throughont the dominion. Thussell v. The Quecn, L. R. 7 A.C. 829, and Attorney-General for Ontario v. Attorney-General for Canada, L. R. [1896] A. C. 348.

The Provincial Legislature under s. 92 (8) can authorize a municipality to pass a by-law prohibiting the sale of liquor, except in certain houses, by limiting the number of public houses, and such an Act is not opposed to s. 91 (2). Corporation of Tlwee Tivers v. Sulte, 2 Cart. 28o (Q. B., Que.) ; Slacin v. Orillia Village, I Cart. 688 (Q. B., Ont.). See also Severn v. The Queen, I Cart. 4I4 (Sup. Ct. of Can.).

An Ontario Act making regulations in the nature of police or municipal regulations of a merely local character for the good government of taverns is valid.

And that Act can entrust to commissioners authority to enact such regulations, and thereby to create offences and annex penalties thereto. Hodge v. The Qucen, L. R. 9 A. C. II 7. 
A brewer's licence is not an 'other licence' within s. 92 (9), Irr. III. and therefore cannot be provided for by a provincial Act. Secern v. The Queen, I Cart. 414 (Sup. Ct. of Can.).

A provincial Act authorizing a city council to make by-laws for preventing vendors of small wares from selling in the streets is valid. Re Harris and City of Hamilton, I Cart. $75^{6}$ (Q. B., Ont.).

Section 91 (12) enables the Dominion Parliament to legislate Fisheries, for the regulation and protection of fisheries as matter's of ${ }^{5.91}$ (12). national concern, e. g. close time, the use of improper instruments; but not as regards the right to fish or the property. in fisheries, which are under s. 92 (13).

And as ss. 109 and 117 reserve to the provinces the fishery rights of the Crown, the Federal Ministry of Marine cannot grant licences to fish in the province, $R$. v. Robertson, 2 Cart. $6_{5}$ (Sup. Ct. of Can.).

The question of what is direct taxation is dealt with in AttorneyGeneral for Quebec v. Recd, L. R. Io A. C. I4I, and Bank of Toronto v. Lambe, L. R. I2 A. C. 584-5.

In the latter case a tax imposed by a provincial Act upon banks and insurance companies carrying on business within the province was held valid, although they were incorporated and had their chief place of business outside the province.

A licence was held by the Supreme Court of Canada to be indirect taxation: Severn v. The Queen, I Cart. 4I ; but as to this see Bank of Toronto v. Lambe, L. R. I2 A. C. $5^{84}$.

A stamp duty on policies of insurance, although called a licence, is not direct taxation, and is therefore invalid. AttomeyGeneral for Quebee v. Queen Insurance Co., L. R. 3 A. C. Iogo.

So also are stamps on legal proceedings applicable to the general revenue of the province. Attomey-Gencral for Quebec v. Riced, L. R. Io A. C. I4I.

The Dominion Parliament cannot directly tax a province in order to raise a revenue for provincial purposes. Bank of Toronto v. Lambe, L. R. I2 A. C. $5^{85}$.

The s. 92 (2) authorizes direct taxation for any local purpose, and not merely for the purpose of the province. Dow v. Black, L. R. 6 P. C. 272.

The power under s. 91 (27) to impose punishment by impris- 'riminal onment involves imprisonment with hard labour. Hodge v. law, lin $_{27}$ ), The Queen, L. R. 9 A. C. 133 .

A rrovincial $\Lambda$ ct for regulating shop licences imposed three months' imprisonment for certain offences against the $\Lambda$ ct. This is valid, as not being opposed to s. 91 (27). R. v. Boardman, I Cart. 676 (Q. B., Ont.).

The procedure affecting penal laws which a Provincial Legislature can pass can be regulated by that legislature, s. 92 (15), 
Apr. III. and is not criminal within s. 91 (27). Pope v. Griffith, and other cases, 2 Cart. 29I, 297, 308, 31 I (Q. B., Que.).

But if the deed which the Provincial Legislature purports to punish is a crime by the law of the dominion, e. g. if the provin. cial Act punishes on conviction before a magistrate the offence of tampering with a witness under the Liquor Law, the Act is ultra vires, notwithstanding s. 92 (8), (9), and (15), because it is an act which is a crime within s. 91 (27). R. v. Lawrence, I Cart. 742 (Q. B., Ont.).

So also the Provincial Legislature cannot alter the general rules of evidence pertaining to criminal procedure throughout the dominion, e.g. by compelling a defendant to give evidence criminating himself. R. v. Roddy, I Cart. 709 (Q. B., Ont.).

It is for the attorney-general of the province to enforce the criminal law in the province, although the law is made by the Dominion Parliament. Attomey-Gcneral v. Niagara Falls Foot Bridge Co., I Cart. 813 (Ct. of Ch., Ont.).

The attorney-general of the province is the proper officer to file an information for the violation of the rights of the public of the province, e.g. obstruction by a railway, although the rights rest on a Dominion Act. If the property of the Crown, as represented by the Government of the Dominion, were affected, it might be otherwise. Attorney-General v. Niagara Falls Foot Bridge Co., I Cart. 8ıз (Ct. of Ch., Ont.).

Justice, A. $92\left(\mathbf{J}_{4}\right)$.

S. 90.

Ss. 65,137 .

The power of the Provincial Legislature to legislate for the administration of justice includes the power to provide for the appointment of police magistrates and justices of the peace by the lieutenant-governor. $R$. v. Bennett, 2 Cart. 634 (Q. B., Ont.). See also R. v. Horner, 2 Cart. 3I7 (Q. B., Que.).

The Act of the Dominion Parliament establishing a maritime court with jurisdiction limited to one province is valid. MeCuaig and Smith v. Keith, i Cart. 557 (Sup. Ct. of Can.).

A Provincial Legislature cannot pass an Act authorizing the removal of county court judges by the lieutenant-governor, or abolishing a court existing before 1867 for the trial of county court judges (s. 96). Re Squier; x Cart. 789 (Q. B., Ont.).

The Provincial Legislature could continue a temporary Act of 1865 enabling the governor to appoint police magistrates. This was not affected by a Dominion Act of 1868, authorizing the governor-general to appoint police magistrates. $R$. v. Reno and Anderson, I Cart. 81o (Q. B., Ont.).

The prerogative power of the Crown to issue commissions of oyer and terminer and gaol delivery remains notwithstanding s. 91 (27) and s. 92 (14), as neither the Dominion nor the Provincial Legislatures have legislated ( $q$ u. which could legislate). R. v. Amer., I Cart. 722 (Q. B., Ont.). 
The establishment by Dominion Act of a court to try election petitions is valid notwithstanding s. 92 (I4); see s. 41 . Valin v. Langlois, L. R. 5 A. C. II5; as to provincial Act, see Théberge v. Laudry, L. R. 2 A. C. 102.

A provincial Act providing for the reduction of the liabilities of an association, which otherwise would be insolvent, is valid under s. 92 (I6), and not within s. 91 (2I). S. 91 refers only to general legislation. L'Union St. Jacques de Montréal v. Belisle, L. R. 6 P. C. 3 I.

An Act authorizing a parish to raise by local taxation a subsidy to a railway which extended beyond the limits of the province is valid under s. 92 (16). Dow v. Black, L. R. 6 P. C. 272.

An Act of the old province of Canada (consisting of the provinces of Ontario and Quebec), which established a corporation, cannot be repealed or modified by the Legislature of either province or by the two Legislatures, but only by the Dominion Parliament. Dobie v. The Temporalities Board, L. R. 7 A. C. 136.

A company to carry on business in more than one province can only be established by the Dominion Parliament, and is validly constituted even though provincial Acts regulated similar companies, and though it carries on business in one province only; but any such company must act in each province-e.g. as respects holding lands in mortmain -in accordance with the law of the province. Colonial Building, \&c. Association v. AttorneyGeneral of Quebec, L. R. 9 A. C. 157 $^{1}$. See also Citizens' Insurance Co. v. Parsons, L. R. 7 A. C. II5-7.

Incorporation by a patent under a provincial Act of a navigation s. $92(10)$. company with operations limited to the province is valid. MLacclougall v. Union Navigation Co., 2 Cart. 228 (Q. B., Que.).

A Dominion Act providing for the liquidation of all building societies, whether solvent or not, is invalid, as it is not under s. 91 (2I), and is contrary to s. 92 (13). MIcClanaghan $v$. St. Ann's Building Society, 2 Cart. 237 (Q. B., Que.).

A provincial Act for dividing a certain testator's property is valid. Re Goodlhue, I Cart. 560 (Ct. of App., Ont.).

The salary of a Dominion officer cannot be taxed by the pro- Miscelvincial government, because $(a)$ he is a Dominion officer, $(b)$ his laneous salary is not wholly in the province. Leprohon v. City of Ottawa, I Cart. 592 (Ct. of App., Ont.).

$\Lambda$ s respects the powers of the provincial Government to grant

'This over-ruled tho decision of the Queen's Beneh of Quebec, 2 C:ırt. 275, and virtually over-ruled a decision of the samo court as rospeets a telephone company which a Dominion Let had empowered to carry on business in more than one provinee, but had not formed for tho purpose of connecting two provinces, of declared to be to the general advantage of Canada or two provinces. R. v. Mohr, 2 Cart. 257. 
Apr. III. land under deep water and rivers, see Normand v. St. Laurence Navigation Co., 2 Cart. 23 I (Q. B., Que.), the grant being impliedly subject to the right of uavigation, which is under the protection of the Dominion Government.

$\therefore$ 108. The provincial Government cannot grant the foreshore of a natural harbour. See Holman v. Green, 2 Cart. I47 (Sup. Ct. of Can.).

S. 92(10). Where a railway has been declared a federal railway, the transfer of it caunot be authorized by a provincial Act. Bourgoin v. La Compagnie du Chemin de Fer de IIontréal, Ottawa, et Occidental, L. R. 5 A. C. 38I, 404.

And where a provincial railway crosses a federal railway the consent of both the Dominion and the provincial Government is required. Credit Valley Railway v. Great Western Railway, I Cart. 822 (Ct. of Ch., Ont.).

But a provincial Act, generally directing compensation to be paid to all trustees for their services, applies to the commissioners of a harbour which is the property of the dominion. Re Toronto Herbour Commissioners, I Cart. 825 (Ct. of Ch., Ont.). 


\section{APPENDIX IV}

\section{GOVERNORS' COMMISSIONS ${ }^{3}$}

\section{CANADA}

I. Patent.

Letrers Patent passed under the Great Seal of the United Apr. IV. Kingdem, constituting the office of Governor-General of the Dominion of Canada.-Letters Patent, dated 5th October 1878 .

Victoris, by the Grace of God, of the United Kingdom of Great Britain and Ireland, Queen, Defender of the Faith, Empress of India ; To all to whom these Presents shall come Greeting :

Whereas We did, by certain Letters Patent under the Great rreamble. Seal of Our United Kingdom of Great Britain and Ireland, bearing date at Westminster the Twenty-second day of May Recites 1872, in the Thirty-fifth Year of Our Reign, constitute and appoint Our Right Trusty and Right Well-beloved Cousin and Councillor, Frederick Temple, Earl of Dufferin, Knight of Our Governorzaud May, Most Illustrious Order of Saint Patrick, Knight Commander of Our Most Honourable Order of the Bath (now Knight Grand Cross of Our Most Distinguished Order of Saint Michael and Saint George), to be Our Governor-General in and over Our Dominion of Canada for and during Our will and pleasure : And whereas by the rath section of 'The British North America Act, 1867,' certain powers, authorities, and functions were declared to be vested in the Governor-General: And whereas We are desirous of making effectual and permanent provision for the office of Governer-General in and over Our said Dominion of Canada, without making new Letters Patent on each demise of the said Office: Know now ye that We have revoked and determined, and by these presents do revoke and determine, the said recited Letters Patent of the Twenty-second day of May

1 For commissions of eighteenth century see Greene, Provincial Governors in the English Colonies of North America, and as to West Indies) Campbell v. Mall, 20 St. Tr. 239, 246, \&c.

Revocation of Governor. General's Commission 22nd May, 1872 . 
Apr. IV. I872, and every clause, article, and thing therein contained: And further know ye that We, of Our special grace, certain knowledge, and mere motion, have thought fit to constitute, order, and declare, and do by these presents constitute, order,

Office of Governo::

General constituted.

Governor's powers and anthorities.

Great Seal.

Appointment of Judges, Justices, \&c.

Suspension or removal from office.

Summoning, proroguing, or dissolving the Domi. nion Parliament. and declare, that there shall be a Governor-General (hereinafter called Our said Governor-General) in and over our Dominion of Canada (hereinafter called Our said Dominion), and that the person who shall fill the said Office of Governor-General shall be from time to time appointed by Commission under Our Sign-Manual and Signet. And We do hereby authorize and command Our said Governor-General to do and execute, in due manner, all things that shall belong to his said command, and to the trust $W_{e}$ have reposed in him, according to the several powers and authorities granted or appointed him by virtue of 'The British North America Act, 1867,' and of these present Letters Patent and of such Commission as may be issued to hin under Our Sign-Manual and Signet, and according to such Instructions as may from time to time be given to him, under Our Sign-Manual and Signet, or by Our Order in Our Privy Council, or by Us through one of Our Principal Secretaries of State, and to such Laws as are or shall hereafter be in force in Our said Dominion.

II. And We do hereby authorize and empower Our said Governor-General to keep and use the Great Seal of Our said Dominion for sealing all things whatsoever that shall pass the said Great Seal.

III. And We do further authorize and empower Our said Governor-General to constitute and appoint, in Our name and on Our behalf, all such Judges, Commissioners, Justices of the Peace, and other necessary Officers and Ministers of Our said Dominion, as may be lawfully constituted or appointed by Us.

IV. And We do further authorize and empower Our said Governor-General, so far as We lawfully may, upon sufficient cause to him appearing, to remove from his office, or to suspend from the exercise of the same, any person exercising any office within Our said Dominion, under or by virtue of any Commission or Warrant granted, or which may be granted, by Us in Our name or under Our authority.

V., And We do further authorize and empower Our said Governor-General to exercise all powers lawfully belonging to Us in respect of the summoning, proroguing, or dissolving the Parliament of Our said Dominion.

VI. And whereas by 'The British North America Act, 1867,' it is amongst other things enacted, that it shall be lawful for Us, if We think fit, to authorize the Governor-General of Our Dominion of Canada to appoint any person or persons, jointly 
or severally, to be his Deputy or Deputies within any part or parts of Our said Dominion, and in that capacity to exercise, during the pleasure of Our said Governor-General, such of the powers, authorities, and functions of Our said Governor-General Deputies. as he may deem it necessary or expedient to assign to such Deputy or Deputies, subject to any limitations or directions from time to time expressed or given by Us: Now $\mathrm{We}_{\mathrm{e}}$ do hereby anthorize and empower Our said Governor-General, subject to such limitations and directions as aforesaid, to appoint any person or persons, jointly or severally, to be his Deputy or Deputies within any part or parts of Our said Dominion of Canada, and in that eapacity to exercise, during his pleasure, such of his powers, functions, and authorities as he may deen it necessary or expedient to assign to him or them : Provided always, that the appointment of such a Deputy or Deputies shall not affect the exercise of any such power, authority, or function by Our said Governor-General in person.

VII. And We do hereby declare Our pleasure to be that, in succession the event of the death, incapacity, removal, or absence of Our to the Gosaid Governor-General out of Our said Dominion, all and every the porvers and authorities herein granted to him shall, until Our further pleasure is signified therein, bo vested in such person as may be appointed by Us under Our Sign-Manual and Signet to be Our Lieutenant-Governor of Our said Dominion; or if there shall be no such Lientenant-Governor in Our said Dominion, then in such person or persons as may be appointed by Us under Our Sign-Manual and Signet to administer the Government of the same; and in case there shall be no person or persons within Our said Dominion so appointed by Us, then in the Senior Officer for the time being in command of Our regular troops in Our said Dominion: Provided that no such powers or authorities shall vest in such Lientenant-Governor, or such other person or persons, until he or they shall have taken the oaths appointed to be taken by the Governor-General of Our said Dominion, and in the manner provided by the Instructions accompanying these Our Letters Patent.

VIII. And We do hereby require and command all Our Officers and Ministers, Civil and Military, and all other the inhabitants of Our said Dominion, to be obedient, aiding, and Proriso. Lieutenant Governor, Sic. to tak $\theta$ oaths of office before administer ing the Go vernment.

Ofticers an others to assist the Governors. assisting unto Our said Governor-General, or, in the event of General. his death, incapacity, or absence, to such person or persons as may, from time to time, under the provisions of these Our Letters Patent, administer the Government of Our said Dominion.

IX. And We do hereby reserve to Ourselves, Our heirs and power ro successors, full power and authority from timo to time to revoke, Majesty to 
Arr. IV. alter, or amend these Our Letters Patent as to Us or them shall seem meet.

revoke, alter, or amend the present Letters Patent.

Publication of Letter: Patent.
Appointment of the Right How. the Lord Stanley of Preston, P.C., G.C.R., as Governo: General.

Recites Letters Patent, lated $5^{\text {th }}$ October, I 878 , consti. tuting the office of GoternorGeneral.

Commissin appointins the Marqui of Lansdowne, G.C.MI.G., as GovernolGeneral,
$\mathrm{X}$. And We do further direct and enjoin that these Our Letters Patent shall be read and proclaimed at such place or places as Our said Governor-General shall think fit within Our said Dominion of Canada.

In Witness whereof We have caused these Our Letters to be made Patent. Witness Ourself at Westminster, the Fifth day of October, in the Forty-second Year of Our Reign.

By Warrant under the Queen's Sign-Manual.

C. Romilly.

\section{Commission.}

Commission passed under the Royal Sign Manual and Signet, appointing the Right Honourable Lord Stanley of Preston, P.C., G.C.B., to be Governor-General of the Dominion of Canada.-Dated ist May I888.

VICTORIA R.

Victoria, by the Grace of God of the United Kingdom of Great Britain and Ireland Queen, Defender of the Faith, Empress of India: To Our Right Trusty and Well-beloved Councillor Frederick Arthur, Baron Stanley of Preston, Knight Grand Cross of Our Most Honourable Order of the Bath, Greeting.

We do by this Our Commission under Our Sign Manual and Signet appoint you, the said Frederick Arthur, Baron Stanley of Preston, to be during Our pleasure Our Governor-General in and over Our Dominion of Canada, with all the powers, rights, privileges, and advantages to the said office belonging or appertaining.

II. And We do hereby authorize, empower, and command you to exercise and perform all and singular the powers and directions contained in Our Letters Patent under the Great Seal of Our United Kingdom of Great Britain and Ireland, bearing date at Westminster, the Fifth day of October 1878, constituting the said Office of Governor-General, or in any other Letters Patent adding to, amending, or substituted for the same, according to such Orders and Instructions as Our Governor-General for the time being hath already received from Us, or as you shall hereafter receive from Us.

III. And further, We do hereby appoint that so soon as you shall have taken the prescribed oaths, and have entered upon the duties of your office, this Our present Commission shall supersede Our Commission under Our Sign Manual and Signet, bearing date the Eighteenth day of August 1883, in the Forty-seventh 
year of Our Reign, appointing Our Right Trusty and Entirelybeloved Cousin Henry Charles Keith, Marquis of Lansdowne, now Knight Grand Cross of Our Most Distinguished Order of Saint Michael and Saint George, to be Our Governor-General of Our Dominion of Canada.

IV. And We do'hereby command all and singular Our Officers, Ministers, and loving subjects in Our said Dominion, and all others whom it may concern, to take due notice hereof, and to give their ready obedience accordingly.

Given at Our Court at Windsor, this First day of May 1888, in the Fifty-first year of Our Reign.

By Her Majesty's Command,

KNUTSFoRD.

\section{Instructions.}

Instructroxs passed under the Royal Sign-Manual and Signet to the Governor-General of the Dominion of Canada.Dated 5 th October 1878.

\section{VICTORIA R.}

Instructions to Our Governor-General in and over Our Dominion of Canada, or, in his absence, to Our Lieutenant-Governor or the Officer for the time being administering the Government of Our said Dominion.

Given at Our Court at Balmoral, this Fifth day of October, 1878 , in the Forty-second year of Our Reign.

Wirereas by certain Letters-Patent bearing even date here- Preamble. with, We have constituted, ordered, and declared that there Recites shall be a Governor-General (herein-after called Our said LettersGovernor-General) in and over Our Dominion of Canada (hereinafter called Our said Dominion), And We have thereby aulthorized and commanded Our said Governor-General to do and execute in due manner all things that shall belong to his said command, and to the trust We have reposed in him, according to the several powers and authorities granted or appointed him l,y virtue of the said Letters-Patent and of such Commission as may be issued to him under Our Sign-Manual and Signet, and according to such Instructions as may from time to time be given to him, under Our Sign-Manual and Signet, or by Our Order in Our Privy Council, or by Us through one of Our J'rincipal Secretaries of State, and to such Laws as are or shall hereafter be in force in Our said Dominion. Now, therefore, We do, by these Our Instructions under Our Sign-Manual and Signet, declare Our pleasure to be that Our said GovernorGeneral for the time being shall, with all due solemnity, cause Our Commission, under our Sign-Manual and Signet, appointing 
Arr. IV. Our said Governor-General for the time being, to be read and published in the presence of the Chief Justice for the time Publication being, or other Judge of the Supreme Court of Our said General's Dominion, and of the members of the Privy Council in Our commission. said Dominion: And We do further declare Our pleasure to Oaths to be taken by Governorlieneral, \&c.

Inperial Aet, 31 \& 32 Vict. (ㄴ). 72. be that Our said Governor-General, and every other officer appointed to administer the Government of our said Dominion, shall take the Oath of Allegiance in the form provided by an Act passed in the Session holden in the thirty-first and thirty-second year's of Our Reign, intituled 'An Act to amend the Law relating to Promissory Oathis'; and likewise that he or they shall take the usual Oath for the due execution of the Office of Our Governor-General in and over Our said Dominion, and for the due and impartial administration of justice; which Oaths the said Chief Justice for the time being of Our said Dominion, or, in his absence, or in the event of his being otherwise incapacitated, any Judge of the Supreme Court of Our said Dominion, shall, and he is hereby required to, tender and administer unto him or them.

Oatlis to be administerel by the Governori ieneral.

GovernorGeneral to communicate instruc tions to the Privy

Council of the Domi. nion.

Laws sent home to hare marginal abstracts.

Journals and Minutes.
II. And We do authorize and require Our said GovernorGeneral from time to time, by himself or by any other person to be authorized by him in that behalf, to administer to all and to every persons or person, as he shall think fit, who shall hold any office or place of trust or profit in Our said Dominion, the said Oath of Allegiance, together with such other Oath or Oaths as may from time to time be prescribed by any Laws or Statutes in that behalf made and provided.

III. And We do require Our said Governor-General to communicate forthwith to the Privy Council for Our said Dominion these Our Instructions, and likewise all such others, from time to time, as he shall find convenient for Our service to be imparted to them.

IV. Our said Governor-General is to take care that all laws assented to by him in Our name, or reserved for the signification of Our pleasure thereon, shall, when transmitted by him, be fairly abstracted in the margins, and be accompanied, in such cases as may seem to him necessary, with such explanatory observations as may be required to exhibit the reasons and occasions for proposing such Laws; and he shall also transmit fair copies of the Journals and Minutes of the proceedings of the Parliament of Our said Dominion, which he is to require from the clerks, or other proper officers in that behalf, of the said Parliament.

V. And We do further authorize and empower Our said Governor-General, as he shall see occasion, in Our name and on Our behalf, when any crime has been committed for which the 
offender may be tried within Our said Dominion, to grant APr. IV. a pardon to any accomplice, not being the actual perpetrator of such erime, who shall give such information as shall lead to the conviction of the principal offender; and further, to grant to any offender convicted of any crime in any Court, or before any Judge, Justice, or Magistrate, within our said Dominion, a pardon, either free or subject to lawful conditions, or any respite of the execution of the sentence of any such offender, for such period as to Our said Governor-General may seem fit, and to remit any fines, penalties, or forfeitures which may become due and payable to Us. Provided always, that Our said Governor-General shall not in any case, except where the offence has been of a political nature make it a condition of any pardon or remission of sentence that the offender shall be banished from or shall absent himself from Our said Dominion. And We do hereby direct and enjoin that Our said Governor-General shall not pardon or reprieve any such offender without first receiving in eapital cases the advice of the Privy Council for our said Dominion, and in other cases the advice of one, at least, of his Ministers; and in any case in which such pardon or reprieve might directly affect the interests of Our Empire, or of any country or place beyond the jurisdiction of the Government of Our said Dominion, Our said Governor-General shall, before deciding as to either pardon or reprieve, take those interests specially into his own personal consideration in conjunction with such advice as aforesaid.

VI. And whereas great prejudice may happen to Our service and to the security of Our said Dominion by the absence of Our said Governor-General, he shall not, upon any pretence whatever, quit Our said Dominion without having first obtained leave from Us for so doing under Our Sign-Manual and Signet, or through one of our Principal Secretaries of State.

Signet.

V. R.

\section{NEW SOUTH WALES}

\section{Patentr.}

Letters Patent passed under the Great Seal of the United Kingdom, constituting the Office of Governor and Commander-in-Chief of the Colony of New South Wales and its Dependencies.-Letters Patent, dated 29th April 1879.

Victoria, by the Grace of God, of the United Kingdom of Great Britain and Ireland, Queen, Defender of the Faith, Empress of India: To all to whom these Presents shall come: Greeting.

Whereas We did, by certain Letters Patent, under the Great rieamble. 
APP. IV. Seal of Our United Kingdom of Great Britain and Ireland, bearing date at Westminster the Twenty-third day of February

Recites

Governor Sir H. G. R. Robinson's Commission, dated 23 rd February, 1872 .

Rerocation of Governor's Commission.

Boundaries.

Gorernor's powers and authorities. 1872, in the Twenty-fifth year of Our Reign, constitute and appoint Our trusty and well-beloved Sir Hercules George Robert Robinson, Knight Commander of Our Most Distinguished Order of Saint Michael and St. George (now Knight Grand Cross of Our said Most Distinguished Order) to be during Our pleasure Our Governor and Commander-in-Chief in and over Our Colony of New South Wales as therein described, and its Dependencies; And whereas We are desirous of making permanent provision for the Office of Governor and Commander-in-Chief in and over Our said Colony of New South Wales and its Dependencies, without making new Letters Patent on each demise of the said Office: Now know ye that We do by these presents revoke and determine the said recited Letters Patent, and everything therein contained: And further know ye that We, of Our special grace, certain knowledge, and mere motion, do by these presents constitute, order, and declare that there shall be a Governor and Commander-in-Chief in and over Our Colony of New South Wales and its Dependencies (which said Colony of New South Wales and its Dependencies are herein-after called the Colony), comprising all that portion of Our territory of Australia or New Holland lying between the one hundred and twenty-ninth and one hundred and fift $y$-fourth degrees of east longitude, and northwards of the fortieth degree of south latitude, including all the islands adjacent in the Pacific Ocean within the longitudes and latitudes aforesaid, and also including Lord Howe Island, being in or abont thirty-one degrees thirty minutes south, and the one hundred and fifty-ninth degree of east longitude, save and except those parts of Our said territory of Australia or New Holland which are ealled respectively 'The Colony of South Australia,' 'The Colony of Victoria,' and 'The Colony of Queensland,' and that appointments to the said Office, when vacant, shall be made by Commission under Our Sign Manual and Signet.

II. We do hereby authorize, empower, and command Our said Governor and Commander-in-Chief (herein-after called the Governor) to do and execute all things that belong to his said Office, according to the tenor of these Our Letters Patent and of such Commission as may be issued to him under Our Sign Manual and Signet, and according to such Instructions as may from time to time be given to him under Our Sign Manual and Signet, or by Our Order in Our Privy Council, or by Us, through one of Our Principal Secretaries of State, and to such Laws as are now or shall hereafter be in force in the Colony.

III. We do also by these Our Letters Patent declare Our will and pleasure as follows:- 
IV. Every person appointed to fill the Office of Governor shall, with all due solemnity, before entering on any of the duties of his Office, cause the Commission appointing him to be Governor to be read and published at the seat of Government, in the presence of the Chief Justice, or some other Juclge of the Supreme Court of the Colony, and of the Members of the Executive Council thereof, which being done, he shall then and there take before them the Oath of Allegiance, in the form provided by an Act passed in the Session holden in the Thirty-first and Thirty-second years of Our Reign, intituled an Act to amend the Law relating to Promissory Oaths; and likewise the usual Oath for the due execution of the Office of Governor, and for the due and impartial administration of justice; which Oaths the said Chief Justice or Judge is hereby required to administer.

V. The Governor shall keep and use the Great Seal of the Great seal. Colony for sealing all things whatsoever that shall pass the said Great Seal.

VI. There shall be an Executive Council for the Colony, and the said Council shall consist of such persons as are now or may at any time be Members thereof in accordance with any Law enacted by the Legislature of the Colony, and of such other persons as the Governor shall, from time to time, in Our name and on Our behalf, but subject to any Law as aforesaid, appoint under the Great Seal of the Colony to be Members of Our said Executive Council.

VII. The Governor, in our name and on Our behalf, may make and execute, under the said Great Seal, grants and dispositions of any lands which may be lawfully granted and disposed of by Us within the Colony.

VIII. The Governor may constitute and appoint, in Our name and on Our behalf, all such Judges, Commissioner's, Justices of the Peace and other necessary Officers and Ministers of the Colony as may be lawfully constituted or appointed by Us.

IX. When any crime has been committed within the Colony, or for which the offender may be tried therein, the Governor may as he shall see occasion, in Our name and on Our behalf, grant a pardon to any accomplice in such crime who shall give firant of such information as shall lead to the conviction of the principal Executive Council: constitution of.

Publication of Governor" Comnission.

Oatlis to be Governor.

Imperial Act, 31 d 32 Vict. c. 72 .

Grant of linds. offender, or of any one of such offenders if more than one; and further may grant to any offender convicted in any Court, or before any Judge, or other Magistrate, within the Colony, a pardon, either free or subject to lawful conditions, or any remission of the sentence passed on such offender, or any respite of the execution of such sentence for such period as the Governor thinks fit; and further may remit any fines, penalties, or for* feitures duo or accrued to Us: Provided always that the Gorernor

Aploint. ment of Judges, Justices, \&c. pardons.

Remiasion of Lines. 
Arr. IV. shall in no case, except where the offence has been of a political nature unaccompanied by any other grave crime, make it a con*

Political offenders. Proviso.

Banishment from Colony prohibited.

Suspension or removal from oftice.

Summoning, proroguing, or dissolving any Legislative Body. Appointment of Menibers.

Succession to the Goveru. ment. LieutenantGovernor.

Adminis. trator.

Proviso. LientenantGovernor, Sc. to take Oaths of office before administer. ing the Government Duties and authorities under Letters Patent.

Governor may appoint a Deputy during lijs temporary absence from seat of Government.

Offiecrs and others to dition of any pardon or remission of sentence that the offender shall absent himself or be removed from the Colony.

$X$. The Governor may, so far as We Ourselves lawfully may, upon sufficient cause to him appearing, remove from his office, or suspend from the exercise of the same, any person exercising any office or place within the Colony, under or by virtue of any Commission or Warrant granted, or which may be granted, by Us in Our name, or under Our authority.

XI. The Governor may exercise all powers lawfully belonging to Us in respect of the summoning, proroguing, or dissolving any Legislative Body, which now is or hereafter may be established within Our said Colony, and in respect of the appointment of Members thereto.

XII. In the event of the death, incapacity, or removal of the Governor, or of his departure from the Colony, Our LieutenantGovernor, or, if there be no such Officer in the Colony, then such person or persons as We may appoint, under Our Sign Manual and Signet, shall, during Our pleasure, administer the Government of the Colony, first taking the Oaths herein-before directed to be taken by the Governor, and in the manner herein prescribed; which being done, We do hereby authorize, empower, and command Our Lieutenant-Governor, and every other such Administrator as aforesaid, to do and execute during Our pleasure all things that belong to the Office of Governor and Commanderin-Chief according to the tenor of these Our Letters Patent, and according to Our Instructions as aforesaid, and the laws of the Colony.

XIII. In the event of the Governor having occasion to be temporarily absent for a short period from the Seat of Government or from the Colony, he may in every such case, by an Instrument under the Great Seal of the Colony, constitute and appoint Our Lieutenant-Governor, or if there be no such Officer then any other person, to be his Deputy during such temporary absence, and in that capacity to exercise, perform, and execute for and on behalf of the Governor during such absence, but no longer, all such powers and authorities vested in the Governor, by these Our Letters Patent, as shall in and by such Instrument be specified and limited, but no others. Provided, nevertheless, that by the appointment of a Deputy as aforesaid, the power and authority of the Governor shall not be abridged, altered, or in any way affected, otherwise than We may at any time hereafter. think proper to direct.

XIV. And We do hereby require and command all Our Officers and Ministers, Civil and Military, and all other the inhabitants 
of the Colony, to be obedient, aiding, and assisting unto the Governor, or to such person or persons as may from time to time, under the provisions of these Our Letters Patent, administer the Government of the Colony.

XV. And We do hereby reserve to Ourselves, Our heirs and Successors, full power and authority from time to time to revoke, alter, or amend these Our Letters Patent as to Us or Then shall seem meet.

XVI. And We do direst and enjoin that these Our Letters Patent shall be read and proclaimed at "such place or places within the Colony as the Governor shall think fit.

In Witness whereof We have caused these Our Letters to be made Patent. Witness Ourself at Westminster, the Twenty-ninth day of April, in the Forty-second year of Our Reign.

By Warrant under the Queen`s Sign Manual.

C. Romilly.

\section{Commission.}

Commission passed under the Royal Sign-Manual and Signet, appointing The Right Honourable Robert William Duff to be Governor and Commander-in-Chief of the Colony of New South Wales and its Dependencies. - Dated 4 th March 1893.

\section{VICTORIA R.}

VICTORIA, by the Grace of God of the United Kingdon of Great Britain and Ireland Queen, Defender of the Faith, Empress of India: To Our Right Trusty and Well-beloved Councillor Robert William Duff, Greeting.

WE do by this Our Commission under Our Sign Manual and Signet appoint you the said Robert William Duff to be Our Governor and Commander-in-Chief in and over Our Colony of New South Wales and its Dependencies during Our pleasure, with all the powers, rights, privileges, and advantages to the said Office belonging or appertaining.

II. And We do hereby authorize, enpower, and command Recites you to exercise and perform all and singular the powers and Patent directions contained in Our Letters Patent under the Great Seal of Our United Kingdom of Great Britain and Ireland, bearing date at Westminster, the twenty-ninth day of $\Lambda$ pril 1879 , constituting the said Office of Governor and Commander-in-Chief, or in any other Our Letters Patent adding to, amending, or substituted for the same, according to such Orders and Instructions as Our said Goveruor and Commander-in-Chief for the time

Appointment of the Pight IIon. R. W. Dutt to be Gover. nor.

constitutin the office ot Goveruor. 
Arr. IV. being hath already received or as you may hereafter receive from Us.

Conunission of 18 th August, 189o, ippointing the Right Hon. the

Earl of Jersey, P.C.,

G.C.M.G., to be Gover. nor, superseded.

Othicers, \&c. to obey Governor.

III. And We do hereby appoint that, as soon as you shall have taken the prescribed Oaths, and have entered upon the duties of your Office, this Our present Commission shall supersede Our Commission under Our Sign Manual and Signet, bearing date the Eighteenth day of August 189o, appointing Our Right Trusty and Right Well-beloved Cousin and Councillor Victor Albert George, Earl of Jersey, Knight Grand Cross of Our Most Distinguished Order of Saint Michael and Saint George, to be Our Governor and Commander-in-Chief in and over Our Colony of New South Wales and its Dependencies.

IV. And $\mathrm{W}_{\Theta}$ do hereby command all and singular Our Officers, Ministers, and loving subjects in Our said Colony and its Dependencies, and all others whom it may concern, to take due notice hereof, and to give their ready obedience accordingly.

Given at Our Court at Windsor, this Fourth day of March I893, in the Fifty-sixth year of Our reign.

$$
\text { By Her Majesty's Command, }
$$

Ripon.

\section{Old Instructions.}

Irstructrons passed under the Royal Sign Manual and Signet to the Governor and Commander-in-Chief of the Colony of New South Wales and its Dependencies.-Dated 29th April 1879.

VICTORIA R. \& I.

Instructions to Our Governor and Commander-in-Clief in and over Our Colony of New South Wales and its Dependencies, or, in his absence, to Our Lieutenant Governor, or the Officer for the time being Administering the Government of Our said Colony and its Dependencies.

Given at Our Court at Windsor, this Twenty-ninth day of April 1879, in the Forty-second year of Our Reign.

Preamble.

Recites Letters constituting the olfice of Governor.

Whereas by certain Letter's Patent, bearing even date herewith, We have constituted, ordered, and declared that there shall be a Governor and Commander-in-Chief (therein and hereinafter called the Governor) in and over Our Colony of New South Wales and its Dependencies (which said Colony and its Dependencies are therein and hereinafter called the Colony): And whereas We have thereby authorized and commanded the Governor to do and execute all things that belong to his said office according to the tenor of Our said Letters Patent and of such Commission as may be issued to him under Our Sign 
Manual and Signet, and according to such Instructions as may from time to time be given to him, under Our Sign Manual and Signet. or by Our Order in Our Privy Council, or by Us through one of Our Principal Secretaries of State, and to such Laws as are now or shall hereafter be in force in the Colony: Now, therefore, We do, by these Our Instructions under Our Sign Manual and Signet, direct and enjoin and declare Our will and pleasure as follows :-

I. The Governor may, whenever he thinks fit, require any person in the public service to take the Oath of Allegiance, together with such other Oath or Oaths as may from time to time be prescribed by any Law in force in the Colony. The Governor is to administer such Oaths or cause them to be administered by some Public Officer of the Colony.

II. The Governor shall forthwith communicate these Our Instructions to Our Executive Council for the Colony, and likewise all such others, from time to time, as he shall find convenient for Our service to impart to them.

III. The said Executive Council shall not proceed to the dispatch of business unless duly summoned by authority of the Gorernor, nor unless two members at the least (exclusive of himself or of the member presiding) be present and assisting throughout the whole of the meetings at which any such business shall be dispatched.

IV. The Governor shall attend and preside at the meetings of the Executive Council, unless prevented by some necessary or reasonable cause, and in his absence such member as may be appointed by him in that behalf, or in the absence of such member the senior member of the Executive Council actually present shall preside; the seniority of the members of the said Council being regulated according to the order of their respective appointments as members thereof.

V. A full and exact journal or minute shall be kept of all the deliberations, acts, proceedings, votes, and resolutions of the Executive Council; and at each meeting of the said Council the minutes of the last meeting shall be read over and confirmed or amended, as the case may require, before proceeding to the dispatch of any other business.

VI. In the execution of the powers and authorities granted to the Gevernor by Our said Letters Patent, he shall in all cases consult with the Executive Council, excepting only in cases which are of such a nature that, in his judgement, Our service would sustain material projudice by consulting the said Council thereupon, or when the matters to be decided are too unimportant to require their advice, or too urgent to admit of their advice being given by the time within which it may be necessary

Oaths to be adninistered by the Governor.

Governor to communicate Instructions to Executire Cuuncil.

Executive Council not to moceed to business noless summoned by the Governor's authority. Quorum.

Governor to preside.

Governor to appoint a President. Senior nein ber to preside in the absence of the Governor and President. Seniority of menber. Jonrnals and minutes to be kept.

Governor to consult Executive Colnueil. 
APP. IV. for him to act in respect of any such matters. In all such urgent

Proviso,

Urgent

cases.

May act in opposition to Executive Council.

Reporting the grounds for 80 doing.

Constitution of the Logislative Council.

Imperial Act,

18 \& 19 Vict. c. 54,1855 . Local Act, No. 41 of 1853 embudied in the above Imperial Act.

Pules to be observed in assenting to, dissenting from, or reserving Bills. Difierent subjects not to be mixed in the same law.

No clause to be introduced foreign $\mathrm{t} o$ what the title imports. Temporary laws.

Description of Bills not to be assented to. cases he shall at the earliest practicable period communicate to the said Council the measures which he may so have adopted, with the reasons thereof.

VII. The Governor may act in the exercise of the powers and authorities granted to him by Our said Letters Patent in opposition to the advice given to him by the members of the Executive Council if he shall in any case deem it right to do so, but in any such case he shall fully report the matter to Us, by the first convenient opportunity, with the grounds and reasons of his action.

VIII. The Governor, with the advice of the Executive Council, is hereby authorized, from time to time, in Our name by an Instrument or Instruments under the Great Seal of the Colony, to summon to the Legislative Council of the Colony such person or persons as the Governor and Executive Council shall think fit, subject to the provisions of an Act passed in the Session of Parliament holden in the Eighteenth and Nineteenth years of Our Reign, intituled An Act to enable Her Majesty to assent to a Bill, as amended, of the Legislature of New South Wales, 'to confer a Constitution on New South Wales, and to grant a Civil List to Her Majesty.'

IX. In the execution of such powers as are vested in the Governor by law for assenting to or dissenting from, or of reserving for the signification of Our pleasure, Bills which have been passed by the Legislature of the Colony, he shall take care, as far as may be practicable, that in the passing of all Laws each different matter be provided for by a different Law, without intermixing in one and the same Law such things as have no proper relation to each other; and that no clause be inserted in or annexed to any Law which shall be foreign to what the title of such Law imports, and that no perpetual clause be part of any temporary Law.

$X$. The Governor shall not assent in Our name to any Bill of any of the classes hereafter specified (that is to say) :-

$x$. Any Bill for the divorce of persons joined together in holy matrimony.

2. Any Bill whereby any grant of land or money, or other donation or gratuity, may be made to himself.

3. Any Bill affecting the currency of the Colony.

4. Any Bill imposing differential duties (other than as allowed by the Australian Colonies' Duties Act, 1873).

5. Any Bill, the provisions of which shall appear inconsistent with obligations imposed upon Us by Treaty.

6. Any Bill interfering with the discipline or control of Our forces in the Colony by land or sea. 
7. Any Bill of an extraordinary nature and importance, whereby Our prerogative, or the rights and property of Our subjects not residing in the Colony, or the trade and shipping of the United Kingdom and its Dependencies, may be prejudiced.

8. Any Bill containing provisions to which Our assent has been refused, or which have been disallowed by Us.

Unless such Bill shall contain a clause suspending the operation of such Bill until the signification in the Colony of Our pleasure thereupon, or unless the Governor shall have satisfied himself that an urgent necessity exists requiring that such Bill be brought into immediate operation, in which case he is authorized to assent in Our name to such Bill, unless the same shall be repugnant to the law of England, or inconsistent with any obligations imposed upon Us by Treaty. But he is to transmit to Us, by the earliest opportunity, the Bill so assented to, together with his reasons for assenting thereto.

XI. The Governor is to take care that all Laws assented to by him in Our name, or reserved for the signification of Our pleasure thereon, shall, when transmitted by him, be fairly abstracted in the margins, and be accompanied, in such cases as may seem to him necessary, with such explanatory observations as may be required to exhibit the reasons and occasions for proposing such laws; and shall also transmit fair copies of the Journals and Minutes of the proceedings of the Legislative Bodies of the Colony, which he is to require from the clerks, or other proper officers in that behalf, of the said Legislative Bodies.

XII. Whenever any offender shall have been condemned to suffer death by the sentence of any Court, the Governor shall call upon the Judge who presided at the trial to make to him a written Report of the case of such offender, and shall cause such Report to be taken into consideration at the first meeting thereafter which may be conveniently held of the Executive Council, and he may cause the said Judge to be specially summoned to attend at such meeting and to produce his notes thereat. The Governor shall not pardon or reprieve any such offender unless it shall appear to him expedient so to do, upon receiving the advice of the said Executive Council thereon; but in all such cases he is to decide cither to extend or to withhold a pardon or reprieve, according to his own deliberate judgement, whether the members of the Executive Council concur therein or otherwise ; entering nevertheless, on the Minutes of the said Executive Council, a Minute of his reasons at length in case he shoukl Regulation
of power of parton in capital cases. Judge's Report to be laid before the Execttive Council. decide any such question in opposition to the judgement of the majority of the members thereof.

XIII. The Governor is required, to the utmost of his power, 
Apr. IV. to promote religion and education among the native inhabitants of the Colony, and especially to take care to protect them in

Promotion of religion and education among the natires.

Protection 'î jersonsana property.

$J$ udges, fic. to be

aplointed during 1'leasure.

Blue Bouk.

Gorernox's absence.

Temporars leare of absence.

Gorernor's absence and devarture from the Colons. their persons, and in the free enjoyment of their possessions, and by all lawful means to prevent and restrain all violence and injustice which may in any manner be practised or attempted against them.

XIV. All Commissions granted by the Governor to any persons to be Judges. Justices of the Peace, or other officers, shall, unless otherwise provided by law, be granted during pleasure only.

XV. The Governor shall forward to Us punctually from year to year, through one of Our Principal Secretaries of State, such annual Returns as have been customarily transmitted to Us from the Colony relative to the revenue and expenditure, defence, public works legislation, civil establishments, pensions, population, schools, course of exchange, imports and exports, agricultural produce, manufactures, and other matters in the said 'Returns' more particularly specified, with reference to the state and condition of the Colony.

XVI. The Governor shall not quit the Colony without having first obtained leave from Us for so doing under Our Sign Manual and Signet, or through one of Our Principal Secretaries of State, except for the purpose of visiting the Governor of any neighbouring Colony for periods not exceeding one month at any one time, nor exceeding in the aggregate one montl for every year's service in the Colony.

XVII. The temporary absence of the Governor for any period not exceeding one month shall not, if he have previously informed Our Executive Council, in writing, of his intended absence, and if he have duly appointed a Deputy in accordance with Our said Letters Patent, be deemed a departure from the Colony within the meaning of the said Letters Patent.

Signet.

V. R. \& I.

\section{Present ${ }^{1}$ Instructions.}

Instructioss passed under the Royal Sign Manual and Signet, to the Governor and Commander-in-Chief of the Colony of New South Wales and its Dependencies. - Dated 9th July I892.

VICTORIA R.I.

Instructions to Our Governor and Commander-in-Chief in and over Our Colony of New South Wales and its Dependencies or to Our Lieutenant Governor or other Officer for the time being administering the Government of Our said Colony and its Dependencies.

[ ${ }^{1}$ This appendix was compiled before the Commonwealth of Australia came into existence.] 
Given at Our Court at Windsor, this Ninth day of July Apr. IV. r 892 in the Fifty-sixth year of Our reign.

Whereas by certain Letters Patent bearing date the Twenty. Preamble ninth day of April 1879 We did constitute, order, and declare that there should be a Governor and Commander-in.Chief (therein and herein-after called the Governor) in and over Our Colony of New South Wales and its Dependencies (which said Colony and its Dependencies are therein and herein-after called the Colony):

And whereas We did thereby authorize and command the Rerites Governor to do and execute all things that belong to his said Patent of office, according to the tenor of Our said Letters Patent, and of such Commission as might be issued to him under Our Sign Manual and Signet, and according to such Instructions as might from time to time be given to him under Our Sign Manual and Signet or by Our Order in Our Privy Council or by us through one of Our Principal Secretaries of State, and to such Laws as were then or should thereafter be in force in the Colony.

And whereas We did issue certain Instructions under Our Recites Sign Manual and Signet, bearing date the Twenty-ninth day of Intructions April 1879 ;

And whereas We are minded to give these further Instructions to Our said Governor :

Now know you that We do hereby revolie the aforesaid Instructions and We do by these Our Instructions under Our Sign Manual and Signet direct and enjoin and declare Our will and pleasure as follows:-

I. In these Our Instructions, unless inconsistent with the context, the term ' the Governor' ' shall include every person for the time being administering the Government of the Colony.

II. The Governor may, whenever he thinks fit, require any person in the public service to take the Oath of Allegiance, together with such other Oath or Oaths as may from time to time be prescribed by any Law in force in the Colony. The Governor is to administer such Oaths or cause them to be administered by some Public Officer of the Colony.

III. The Governor shall forthwith communicate these Our Instructions to the Executive Council, and likewise all such others, from time to time, as he shall find convenient for Our Service to impart to them.

IV. The Governor shall attend and preside at the meetings of the Executive Council, unless prevented by some necessary or reasonable cause, and in his absence such momber as may be appointed by him in that behalf, or in the absence of such nember the senior member of the Executive Council actually present shall presicle; the seniority of the members of the said

Oaths to be alministered by Gorernor.

teroke aforesaid
Instructions. I 879 . constituting the Office of 1879 . 
Arr. IY. Council being regulated according to the order of their respective appointments as members thereof.

and Presi. dent.

Seniority of nembers.

Quorum.

Governor to take advice of Executive Conneil.

Constitution uf the legis. lativo Council.

Imperiul Act, 18 \& 19 Vict. c. 54,1855 . Loeal Act, No. 4 I of 1853 ; Seliedule to the Imjerial Act.

Description of Bills not to be assented to.

V. The Executive Council shall not proceed to the dispatch of business unless duly summoned by authority of the Governor nor unless two members at the least (exclusive of the Governor or of the member presiding) be present and assisting throughout the whole of the meetings at which any such business shall be dispatched.

VI. In the execution of the powers and authorities vested in him, the Governor shall be guided by the advice of the Executive Council, but if in any case he shall see sufficient cause to dissent from the opinion of the said Council, he may act in the exercise of his said powers and authorities in opposition to the opinion of the Council, reporting the matter to Us without delay, with the reasons for his so acting.

In any such case it shall be competent to any member of the said Council to require that there be recorded upon the Minutes of the Council the grounds of any advice or opinion that he may give upon the question.

VII. The Governor, with the advice of the Executive Conncil, is hereby authorized, from time to time, in Our name by an Instrument or Instruments under the Great Seal of the Colony, to summon to the Legislative Couneil of the Colony such person or persons as the Governor and Executive Council shall think fit, in accordance with the provisions of an Act passed in the Session of Parliament holden in the Eighteenth and Nineteenth years of Our Reign, intituled An Act to enable Her Majesty to assent to a Bill, as amended, of the Legislature of New South Wales 'to confer' a Constitution on New South Wales, and to grant a Civil List to Her Majesty.'

VIII. The Governor shall not, except in the cases hereunder mentioned, assent in Our name to any Bill of any of the following classes:-

I. Any Bill for the divorce of persons joined together in holy matrimony.

2. Any Bill whereby any grant of land or money, or other donation or gratuity, may be made to himself.

3. Any Bill affecting the currency of the Colony.

4. Any Bill imposing differential duties (other than as allowed by the Australian Colonies' Duties Act, 1873).

5. Any Bill, the provisions of which shall appear inconsistent with obligations imposed upon Us by Treaty.

6. Any Bill interfering with the discipline or control of Our forces in the Colony by land or sea.

7. Any Bill of an extraordinary nature and importance, whereby Our prerogative, or the rights and property of 
Our subjects not residing in the Colony, or the trade and APr. IV. shipping of the United Kingdom and its Dependercies, may be prejudiced.

8. Any Bill containing provisions to which Our assent has been once refused, or which have been disallowed by $U_{s}$;

Unless he shall have previously obtained Our Instructions upon such Bill through one of Our Principal Secretaries of State, or unless such Bill shall contain a clause suspending the operation of such Bill until the signification in the Colony of Ou pleasure thereupon, or unless the Governor shall have satisfied himself that an urgent necessity exists requiring that such Bill be brought into immediate operation, in which case he is authorized to assent in Our name to such Bill, unless the same shall be repugnant to the law of England, or inconsistent with any obligations imposed upon Us by Treaty. But he is to transmit to $\mathrm{Us}_{\mathrm{s}}$ by the earliest opportunity the Bill so assented to, together with his reasons for assenting thereto.

IX. The Governor shall not pardon or reprieve any offender without first receiving in eapital cases the advice of the Executive Council, and in other cases the advice of one, at least, of his Ministers; and in any case in which such pardon or reprieve might directly affect the interests of Our Empire, or of any country or place beyond the jurisdiction of the Government of the Colony, the Governor shall, before deciding as to either pardon or reprieve, take those interests specially into his own personal consideration in conjunction with such advice as aforesaid.

X. All Commissions granted by the Governor to any person to be Judges, Justices of the Peace, or other officers, shall, unless otherwise provided by law, be granted during pleasure only.

XI. The Governor shall not quit the Colony without having first obtained leave from Us for so doing under Our Sign Manual and Signet, or through one of Our Principal Secretaries of State, except for the purpose of visiting the Governor of any neighbouring Colony for periods not exceeding one month at any one Temporary time, nor exceeding in the aggregate one month for every year's leave of service in the Colony.

XII. The temporary absence of the Governor for any period not exceeding one month shall not, if ho have previously informed the Executive Council, in writing, of his intended absence, and if he have duly appointed a Deputy in accordance with Our said Letters Patent, bo deemed a departure from tho Colony within the meaning of the said Letters Patent.

Signet.

V. R. I. to be appointed during

Governor's absence.

Governor's absence and departure from the Gulony. Interpretation Clasuse. 


\section{INDIA .}

Warrant of Appointment of the Viceroy and GovernorGENERAL OF INDIA.

VICTORIA R. \& I.

Apr. IV. Victoria, by the Grace of God of the United Kingdom of Great Britain and Ireland Queen, Defender of the Faith, Empress of India.

'I o Our Right Trusty and Right Well-beloved Cousin and Councillor, Victor Alexander, Earl of Elgin and Kincardine, Greeting.

The Earl of Elgin and Kincardine appointed

Viceroy and GovernorGeneral of India.

Whereas by an Act passed in the Session of Parliament holden in the twenty-first and twenty-second years of Our Reign, intituled 'An Act for the better Government of India,' it is enacted that the appointment of Governor-General of India shall be made by Us by Warrant under Our Royal Sign Manual :

Now know that We, reposing especial trust and confidence in the Fidelity, Prudence, Justice, and Circumspection of you the said Victor Alexander, Earl of Elgin and Kincardine, have nominated, made, constituted, and appointed you, the said Victor Alexander, Earl of Elgin and Kincardine, to be Governor-General of India and of all and singular our Forts, Factories, Settlements, Lands, Territories, Countries, Places, and Provinces which now are or shall from time to time be subject to or under Our Government in the East Indies, and to execute all and every the powers and authorities committed, continued, or given to Our Governor-General of India, by or under or in virtue of a certain Act passed in the Session of Parliament holden in the third and fourth years of the Reign of his late Majesty King William the Fourth, chapter 85 , and by or under or in virtue of any other Act or Acts of Parliament now in force, to take upon you, hold, and enjoy the said Office upon and from the death, resignation, or coming away of Henry Charles Keith, Marquis of Lansdorvne, Governor-General of India, whichever of those events shall first happen, and to continue in the exercise of the said Office during Our Will and Pleasure, subject nevertheless to such Instructions and Directions as you, the said Victor Alexander, Earl of Elgin and Kincardine, shall as Governor-General of India, or as Governor-General of India in Council, from time to time receive under the hand of one of Our Principal Secretaries of State. And We do hereby authorize and empower and require you, the said Victor Alexander, Earl of Elgin and Kincardine, to execute and perform all and every the powers and authorities to the said Office of Governor-General of India appertaining. 
And We do hereby give and grant unto you, the said Victor APr. IV. Alexander, Earl of Elgin and Kincardine, Our said GovernorGeneral of India, and your Council, as the Governor-General of India in Council, the superintendence, direction, and control of the whole Civil and Military Government of all Our said Territories and Revenues in India, with full power and authority to superintend and control the Governors and Governors in Council respectively of all Our Presidencies in the East Indies in all points relating to the due administration of such Presidencies respectively; and also with all such powers and authorities jointly, severally, and respectively, and subject to all such restrictions and conditions as are given to them respectively or created by or under or by virtue of the said Act passed in the Session of Parliament holden in the third and fourth years of the reign of his said late Majesty King William the Fourth or any other Act or Acts of Parliament now in force. And We do hereby order and require all Our Servants, Officers and Soldiers in the East Indies, and all the people and inhabitants of the Territories under Our Government, and also all Our Governors and Councils of our respective Presidencies in the East Indies, to conform, submit, and yield due obedience unto you, the said Victor Alexander, Earl of Elgin and Kincardine, Our said Governor-General of India, and your said Council accordingly.

Given at Our Court at Balmoral the 26th day of October in the year of Our Lord one thousand eight hundred and ninetythree, in the fifty-seventh year of Our Reign.

\section{By Her Majesty's Command,}

Kraperley.

\section{SOUTH AFRICA}

\section{Commission of Hiait Commissioner.}

Commrssiox passed under the Royal Sign Manual and Signet, appointing the Governor and Commander-in-Chief or the Officer for the time being administering the Government of the Colony of the Cape of Good Hope to be High Commissioner for South Africa.

\section{VICTORIA R.}

Victoris, by the Grace of God of the United Kingdom of Great nated zoth Britain and Ireland Queen, Defender of the Faitl, Empress Auguet 1889 of India: To Our Governor and Commander-in-Chief or other Officer for the time leing administering the Government of Our Colony of the Cape of Good Hope, with its Territories and Dependencies, Greeting. 
Arp. IV. Whereas by Our Commission under Our Sign Manual and Signet, bearing date at Windsor the Twenty-ninth day of Rewites Conl- February 188.4, We did appoint Our Right Trusty and Wellniission of
29 th Febvuary $188_{4}$, appointing the Riglit

IIon. Sir $\mathbf{H}$. G. R. Robinson,

G.G.M.G., to be iligh Commine sioner.

Recites

Order in

Conneil of

and Feb-

lutury 1884,

resuming

direct

anthority

orer

Basitoland.

Alumint-

Itent of

Governor or Officel for the time being administeling tlie

Govermment of the Cape Colony to be High Com-

missioner.

Powers and dutits of

High Com. missioner.

High Com. missioner enipowered to transact all lawful business witl Republics, \&e. beloved Councillor Sir Hercules George Robert Robinson, Knight Grand Cross of Our Most Distinguished Order of Saint Michael and Saint George, to be Our High Commissioner for South Africa :

And whereas We did, by Our Order in Our Privy Council bearing date the Second day of February 1884 , resume direct authority over Our Territory of Basutoland :

And whereas We do exercise influence in Bechuanaland, Matabeleland, and other Countries adjoining thereto, in aid and protection of the Native Chiefs and peoples residing therein :

And whereas We are now minded to make further provision for the due execution of the duties of Our said High Commissioner in the conduct of Our affairs in South Africa :

Now therefore We do, by this Our Commission under Our Sign Manual and Signet, appoint you, Our said Governor and Commander-in-Chief for the time being of Our Colony of the Cape of Good Hope, with its Territories and Dependencies, or you, the Officer for the time being administering the Government thereof, to be during Our pleasure Our High Commissioner for South Africa, and as such High Commissioner to act in Our name and on Our behalf, and in all respects to represent Our Crown and authority in matters occurring in South Africa beyond the limits of Our Colonies of the Cape of Good Hope and Natal, and Our Territories of British Bechuanaland, Basutoland, and Zululand respectively, and beyond the limits of any other place or territory in South Africa, in and over which We may from time to time have appointed a Governor.

II. And We do hereby authorize, empower, and command you to exercise in Our name and on Our behalf all powers in regard to Basutoland which are vested in Our said High Commissioner by Our aforesaid Order in Our Privy Council, bearing date the Second day of February 188, and further to take all such measures and to do all such matters and things in Bechuanaland, Matabeleland, and other Countries adjoining thereto, as in the interest of Our service you may think expedient, subject to such Instructions as you may from time to time receive from Us or through one of Our Principal Secretaries of State.

III. And We do hereby authorize, empower, and command you, as such Our High Commissioner, to transact in Our name and on Our behalf all business which may lawfully be transacted by you with the President or Representatives of the Republic of the Orange Free State or of the South African Republic, or with the Representative of any Foreign Power, subject nevertheless 
to such Instructions as you may from time to time receive from Us or through one of Our Principal Secretaries of State. And We do empower you. if occasion shall so require, to appoint British Officers to reside within the said Republics or either of them, and to transact such business as you may entrust to them. And We do require you, by all proper means, to invite and obtain the co-operation of the Gorermments of the said Republics or of any Foreign Power towards the preservation of peace and safety in Sonth Africa, and the general welfare and adrancement of its territories and peoples.

IV. And We do hereby authorize, emporrer, and command you as such Our High Commissioner, in Our name and on Our behalf, to take all such measures, and to do all such things, in relation to the Native Tribes in South Africa with which it is expedient that We should have relations, and which are not included within the territory of either of the said Repnblics or of any Foreign Power, as are lawful and appear to you to be advisable for maintaining Our Possessions in peace and safety. and for promoting the peace, order, and good government of the Tribes aforesaid, and for preserving friendly relations with them.

$V$. And We do hereby authorize and empower you, by Instruments under your hand and seal, to appoint so many fit persons as in the interest of Our Service you shall think necessary to be your Deputy Commissioners, or to be Resident Commissioners or Assistant Commissioners, and by the same or other Instruments to define the districts within which such officers shall respectively discharge their functions: And We do hereby authorize and empower every such Deputy or Resident or Assistant Commissioner to have and exercise within his district such of the powers and authorities hereby conferred upon you, Our said High Commissioner, as you shall think fit to assign to him by the Instrument appointing him, subject nevertheless to such directions and instructions as you may from time to time think fit to give him. And We do declare that the appointment proviso. of such Deputy or Resident or Assistant Commissioners shall not abridge, alter, or affect the right of you, Our said High Commissioner, to execute and clischarge all the powers, authorities, and functions of your said office.

VI. And We do hereby further authorize and empower you, as occasion may require, to appoint such Border Agents and other Officers as you may think necessary, if provision shall have been made for their payment.

VII. And further Wo do hereby appoint that so soon as you shall have caused this Our Commission to be pulblished in South Africa, this Our present Commission shall supersede Our above recited Commission of the 'Twenty-ninth day of February $188_{4}$,

High Com. missioner empowered to alyoint Dernity, Resident, or Assintant Comuruis. sioners.

Powers anel autloritie. of suc! Conn . nissinater.

Aprint nent of Agentis, \&ie. The Right (i. K. Rubinson's ('ommission at 
Apr. IV. appointing Our Right Trusty and Well-beloved Couneillor Sir Hercules George Robert Robinson to be Our High Commissioner

High ('ominissioner, of zoth $\mathrm{Feb}$. ruary $188_{4}$, superscded. Officers and others to aid and assist said Gover. nor', ite. as therein mentioned.

VIII. And We do hereby command all and singular Our Officers and Ministers, Civil and Military, and all the inhabitants of Our Possessions, and all other Our loyal subjects in Sonth Africa, to be aiding and assisting unto you, Our said Governor and Commander-in-Chief for the time being, or you, the Officer for the time being administering the Government of Our said Colony, in execution of this Our Commission.

Given at Our Court at Osborne House, Isle of Wight, this Twentieth day of August 1889, in the Fifty-third year of Our Reign.

By Her Majesty's Command,

Kyutsford.

\section{WESTERN PACIFIC}

\section{Commission of High Commissioner.}

Commission passed unlel the Royal Sign Míanual and Signet, appointing Sir George Thomas Michael O'Brien, K.C.M.G.. to be Her Britannic Majesty's High Commissioner for the Western Pacific.

\section{VICTORIA R.}

Dated 9th March I897.

Recites Order in Council of 15th March 2893.

Alpoint. ment of Sir G. T. M. O'Brien. K.C.M.U.,
Victoria, by the Grace of God of the United Kingdom of Great Britain and Ireland Queen, Defender of the Faith, Empress of India: To Our Trusty and Well-beloved Sir George Thomas Michael O'Brien, Knight Commander' of Our Most Distinguished Order of Saint Michael and Saint George, Our Governor and Commander-in-Chief in and over Our Colony of Fiji, Greeting.

Whereas by Our Order in Our Privy Council bearing date the Fifteenth day of March 1893 , We have made provision for the government of Our subjects in certain islands and places in the Western Pacific Ocean, and have constituted and continued the office of High Commissioner in, over, and for such islands and piaces, or some of them, and have declared that the person for the time being filling the said office shall continue to be styled - Her Britannic Majesty's High Commissioner for the Western Pacific':

Now know you that We do by these Presents constitute and appoint you, the said Sir George Thomas Michael O'Brien, to be during Our pleasure Our High Commissioner for the Western Pacific, with all such powers and authorities as may be necessary 
for the due execution of the provisions contained in Our said Order in Council, or in any other Our Order in Council adding to, amending, or substituted for the same, according to such Orders and Instructions as Our said High Commissioner for the time being hath already received from Us, or as you may hereafter receive from Us.

II. And We do hereby command and require all Our Officers and Ministers, eivil and military, and all other Our loyal subjects in the said Western Paeifie Islands, to be aiding and assisting unto you, the said Sir George Thomas Michael O'Brien, as High Commissioner.

Given at Our Court at Saint James's, this Ninth day of March 1897, in the Sixtieth year of Our Reign.

By Her Majesty's Command,

J. Cimamberlais.

\section{PROTECTED MALAI STATES}

Commission of Higil Commisstoner.

Commssios passed under the Royal sign Manual and Signet, appointing the Officer for the time being administering the Government of the Straits Settlements and their Dependencies, to be High Commissioner for the Protected States in the Malay Peninsuliı.

VICTORIA R.

Victoria, by the Grace of God of the United Kingdom of Dated

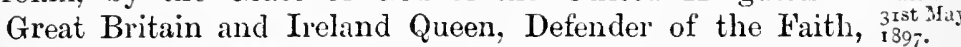
Empress of India: To Our Governor and Commander-inChief in and over Our Straits Settlements, or, in his absence. to Our Lientenant-Gorernor or the Officer for the time being administering the Government of Our said Straits Settlements and their Dependencies, Greeting.

Whereas We did, by Our Commission under Our Sign Recites ComManual and Signet bearing date the Third day of July I896, appoint Our Trusty and Well-beloved Lieutenant-Colonel Sir Charles Bullen Hugh Mitehell, Knight Grand Cross of Our Most Distinguished Order of Saint Michael and Saint George, Our Governor and Commander-in-Chief of Our Straits Settlements and their Dependencies, to be during Our pleasure Our High Commissioner for the Federated States in the Malay Peninsula of Perak, Selangor, Negri Sembilan, and Pahang, which were then and are now under Our protection, and for any other Territories within the said Peninsula which might at any time thereafter be under Our protection: ing LielltenantC. 13.11 . Mitchell, G.C.MI.C. Governor af the straits siettlenents, to be Iligle Comminissioner for the Protected States in the Malay reninsula. 
Apr. IV. And whereas We are minded to make fresh provision for filling the office of Our IIigh Commissioner of the said Federater States and Territories in the Malay Peninsula; and for the due execution of the duties thereof:

Alpuintunent of the Otticer for the time being $A d$. misistering the Govern. unent of the Straitsisettle. ments, to be High Conmissioner.

Commision of $3^{\mathrm{rd}} \mathbf{J} 1 z \mathrm{ly}$ 1896 snpelseded.

Now therefore WVe do by this Our Commission under Our Sign Manual and Signet appoint you, Our said Governor and Commander-in-Chief in and over Our Straits Settlements, or, in your absence, Our Lieutenant-Governor, or the Officer for the time being administering the Govermment thereof, to be Our High Commissioner to act in Our name and on Our behalf, and in all respects to represent Our Crown and authority in matters occurring within the said States and Territories, and further to take all such measures and to do all such matters and things in the States and Territories aforesaid as in the interest of Our service you may think expedient, subject to such Instructions as you may from time to time receive from $U_{s}$ or through one of Our Principal Secretaries of State.

II. And We do hereby appoint that, so soon as you shall have caused this Our Commission to be published in the said States, this Our present Commission shall supersede Our above-recited Commission of the Third day of July I895 appointing Our said Trusty and Well-keloved Sir Charles Bullen Hugh Mitchell to be Our High Commissioner as therein set forth.

III. And further We do hereby command all and singular Commission.

Our subjects to take due notice of this Our Commission, and to yield obedience thereunto, and to be abiding and assisting unto you, Our said High Commissioner, in execution of this Our Commission.

Given at Our Court at Saint James s, this Thirty-first day of May 1897, in the Sixtieth year of Our Reign.

$$
\text { By Her Majesty's Command, }
$$

J. Chinmberlain. 


\section{APPENDIX V}

\section{COLONIAL LAWS VALIDITY ACT, 1865 , $28 \& 29$ VICT. с. 63}

An Act to remore Doubts as to the Validity of Colonial Law's ${ }^{1}$.

Arp. V.

[29th June I865.]

Whereas doubts have been entertained respecting the validity of divers laws enacted or purporting to have been enacted by the legislatures of certain of Her Majesty's colonies, and respecting the powers of such legislatures, and it is expedient that such doubts should be removed :

Be it hereby enacted by the Queen's most Excellent Majesty, by and with the Advice and Consent of the Lords Spiritual and Temporal, and Commons, in this present Parliament assembled, and by the authority of the same, as follows:

1. The term 'colony' shall in this Act include all of Her Majesty's possessions abroad in which there shall exist a legislature, as herein-after defined, except the Channel Islands, the Isle of Man, and such territories as may for the time being be vested in Her Majesty under or by virtue of any Act of Parliament for the government of India :

The terms 'legislature' and 'colonial legislature' shall severally signify the authority, other than the Imperial Parliament or Her Majesty in Council, competent to make laws for any colony:

The term 'representative legislature' shall signify any colonial legislature which shall comprise a legislative body of which one 'Legislature.' 'Colonial legis lature.' 'Represer. tative legislature.' half are elected by inhabitants of the colony :

'The term 'colonial law' shall include laws made for any 'Colonial colony either by such legislature as aforesaid or by Her Majesty in Council :

An Act of Parliament, or any provision thereof, shall, in Act of larconstruing this Act, be said to extend to any colony when it is made applicable to such colony by the express words or necessary intendment of any Act of Parliament:

lianent, \&ic. to exterid to colony wlien made appli. cable to sticls culony.

' Short title; The Colonial Laws Validity Act, 1865 , given by 59 \& 60 Vict. c. I4. 
Apr. V. The term 'governor' shall mean the officer lawfully administering the government of any colony :

'(iovernor.' The term 'letters patent' shall mean letters patent under the 'Letters Patent.'

Colonial law when roid for re. pugnancy.

Colonial Iaw when not void for reprignancy.

Colonial

law not roid for inconsis. tency with instructions.

Colonial legislature may establish, \&c. courts of law.

liepresentative legislature nuay alter constitution.

Certified corpies of laws to be exidence that they are properly passed. Great Seal of the United Kingdom of Great Britain and Ireland.

2. Any colonial law which is or shall be in any respect repugnant to the provisions of any Act of Parliament extending to the colony to which such law may relate, or repugnant to any order or regulation made under authority of such Act of Parliament, or having in the colony the force and effect of such Act, shall be read subject to such Act, order, or regulation, and shall, to the extent of such repugnancy, but not otherwise, be and remain absolutely void and inoperative.

3. No colonial law shall be or be deemed to have been void or inoperative on the ground of repugnancy to the law of England, unless the same shall be repugnant to the provisions of some such Act of Parliament, order, or regulation as aforesaid.

4. No colonial law, passed with the concurrence of or assented to by the governor of any colony, or to be hereafter so passed or assented to, shall be or be deemed to have been void or inoperative by reason only of any instructions with reference to such law or the subject thereof which may have been given to such governor by or on behalf of Her Majesty, by any instrument other than the letters patent or instrument authorizing such governor to concur in passing or to assent to laws for the peace, order, and good govermment of such colony, even though such instructions may be referred to in such letters patent or lastmentioned instrument.

5. Every colonial legislature shall have, and be deemed at all times to have had, full power within its jurisdiction to establish courts of judicature, and to abolish and reconstitute the same, and to alter the constitution thereof, and to make provision for the administration of justice therein; and every representative legislature shall, in respect to the colony under its jurisdiction, have, and be deemed at all times to have had, full power to make laws respecting the constitution, powers, and procedure of such legislature; provided that such laws shall have been passed in such manner and form as may from time to time be required by any Act of Parliament, letters patent, Order in Council, or colonial law for the time being in force in the said colony.

6. The certificate of the clerk or other proper officer of a legislative body in any colony, to the effect that the document to which it is attached is a true copy of any colonial law assented to by the governor of such colony, or of any bill reserved for the signification of Her Majesty's pleasure by the said governor, shall be prima facie evidence that the document so certified is a true 
copy of such law or bill, and, as the case may be, that such law has been duly and properly passed and assented to, or that such bill has been duly and properly passed and presented to the governor; and any proclamation purporting to be published by authority of the governor in any newspaper in the colony to which such law or bill shall relate, and signifying Her Majesty's disallowance of any such colonial law, or Her Majesty's assent to any such reserved bill as aforesaid, shall be prima facic evidence of such disallowance or assent.

And whereas doubts are entertained respecting the validity of certain Acts enacted or reputed to be enacted by the legislature of South Australia: Be it further enacted as follows :

7. All laws or reputed laws enacted or purporting to have Certain Acts been enacted by the said legislature, or by persons or bodies of enacted by persons for the time being acting as such legislature, which have of South received the assent of Her Majesty in Council, or which have to be valii. received the assent of the governor of the said colony in the name and on belsalf of Her Majesty, shall be and be deemed to have been valid and effectual from the date of such assent for all purposes whatever; provided that nothing herein contained shall be deemed to give effect to any law or reputed law which has been disallowed by Her Majesty, or has expired, or has been lawfully repealed, or to prevent the lawful disallowance or repeal of any law. 


\title{
APPENDIX VI
}

\section{REPORT ON BRITISH JURISDICTION IN FOREIGN STATES}

\author{
By the late Mr. Hope Scott, Q.C.
}

Lincoln's Inn, January 18, 1843.

APP. VI. THE object to which my attention has been immediately directed is that of the establishment by Great Britain of a Criminal Jurisdiction in the Levant; but I have conceived that it might be useful to extend the following observations beyond the limits thus marked out, and to include in them as well the question of civil jurisdiction in that quarter, as those which may arise, whether in civil or eriminal matters, in other parts of the world.

Indeed even if I had not been led to a direct adoption of this course by considerations arising out of the still unsettled condition of our civil jurisdiction in the East, and by the knowledge (however imperfect) which I have acquired of the existence of similar powers in other quarters of the world, it would have been impossible to solve that which appears to be the most important part of the question immediately before me-I mean the definition of the constitutional authority of the Crown in respect of jurisdiction thus acquired-without, at the same time, establishing principles, the recognition of which in any single instance would entail an obligation to give them general effect.

Having said thus much in explanation of the purport of the following paper, I will add a few words as to the method in which it is framed.

I. Although I have directed attention to similar questions generally, yet as the documents referred to me do not comprise any information as to the British jurisdiction in those countries which are not subject to the Porte, I have taken the accounts of the jurisdiction within the Turkish dominions as the chief basis of my observations.

2. The subject being one of a mixed character, partly international, and partly domestic, I have throughout endeavoured, as far as possible, to distinguish from each other the questions incident to either portion of it. 
3. I have bestowed more care upon establishing the principle APr. VI. and the main features of the jurisdiction, than upon details for its exercise ; these latter being in my opinion more fit for local and gradual institution, than for summary legislation, whether by the Crown alone, or by Parliament at home.

Of the two points of view from which the British jurisdiction in the Levant may be contemplated, that which presents it as an international question seems naturally to obtain the first place.

The principle declared by the maxim of the civil law, 'Extra territorium ius dicenti impune non paretur' ", is one so necessarily connected with the first idea of independent sovereignties, and so fully recognized throughout the civilized world, that to speak of legislative or judicial acts to be performed by one supreme power within the dominions of another, without first showing some special authority ${ }^{2}$ by which to support them, would be to discredit the whole system of international jurisprudence.

But it is evident that the sovereign right to exclude also implies that of admitting the influence of foreign Governments ; and the convenience of nations having friendly relations with each other has at all times required and obtained a departure from the strict rule above laid down.

The forms under which such concessions have for the most part been made, are-

I. The recognition of foreign laws in particular cases by the local tribunals.

2. The partial or total exemption of the subjects of foreign Powers from the jurisdiction of these tribunals, and the allow. ance of their own laws and judges.

Of these the former appears to be in some sort necessary for the maintenance of intercourse amongst nations, and does not materially interfere with the notion of territorial sovereignty ; and accordingly we find that, by 'comity,' various modifications of it are generally observed.

The latter, especially in mixed suits between natives and foreigners, and above all, in criminal cases of whatever description, implies pro tanto, an abdication of sovereignty, which must not in any case be hastily assumed, and which, amongst civilized Powers, in these days rarely occurs.

It is certain, however, that in earlier times this latter juris-

1 Dig. lib. 2, tit. i, 1. 20.

2 I have not thought it worth while to consider the case of ambassadors and their dependents under the general law of nations. The curious illustration of it furnished by the proceedings of Sully (Vattel, Droit des Gons, lib. iv, claap. 9) would hardly be considered a precedent in these days. The case, too, of the Portuguose minister, in Cromwell's time, is the other way. 
Apr. VI. diction (with which alone we are now concerned) was very generally allowed, and that it still exists both in the Levant and elsewhere.

From the laborious compilation of De Miltitz ${ }^{1}$ it appears that traces of such a jurisdiction are to be found as early as the sixth century B. c., and thence downwards from time to time, until, at the period of the Crusades, it obtained in the Levant a form not materially dissimilar from that in which we have now to consider it.

The purposes of its first institution were purely commercial, and for the settlement of differences amongst the merchants of the particular nation to which it was conceded; and such were probably always its limits in the Western States, and, partieularly in England, where the introduction of it appears to have been comparatively late and partial ${ }^{2}$. But in the Levant there were many circumstances which enabled foreign States, and particularly the mercantile powers of Italy, to obtain a firmer footing ; and there is abundant proof of their having established, both under the Christian and the Mahomedan rulers of these districts, a sort of independent sovereignty, sometimes coupled with territory, and often extending alike to crimes and to civil proceedings of whatever description ${ }^{3}$.

It was probably with a regard to these precedents that the French Capitulations with the Porte in $\mathbf{5} 535$ were framed; and though England and Scotland neglected to take advantage of the right then reserved to them by Francis $I^{4}$, the Capitulations obtained in 1579 , and at subsequent periods, placed Great Britain in the same position as France and other favoured Powers.

The British jurisdiction in the Turkish dominions as it now exists, may be thus described. It rests-

(I) ${ }^{6}$ Upon Capitulations with the Porte, and upon usage more or less fully acquiesced in by that Power;

1 Manuel des Consuls, par A. de Miltitz. Londres et Berlin, 1837, tom. i, p. 9 ; and tom. ii, part 1 , lib. 2, chap. $r$.

2 Cf. Miltitz, tom. i, lib. I, chap. 5, sec. 6 ; tom. ii. part r, lib. 2, chap. $r$, sec. 3 , p. 334 ; ibid., p. 356 ; ibid., chap. 2 , sec. 3 , p. $460, \&$ e.

${ }^{3}$ Cf. Miltitz, tom. ii, part I, lib. 2, chap. I, generally ; and chap. 2, sec. 2, p. 423 et seq. ; sec. 3, p. $43^{\mathrm{I}}$ et seq. See also Lewis on the Government of Dependencies, p. 142 et seq.

4 Miltitz, tom. i, lib. I, chap. 5, sec. 13, p. 525; ibid., tom. ii, part r, lib. 2, chap. I, sec. 3, p. 2 I9.

3 The Articles of the Capitulations with Great Britain affecting the question of jurisdiction are the following:-VIII, IX, X, XI, XIV, XV, XVI, XXIV, XXV, XXVI, XXXIII, XLII, XLV, XLVI, LVIII, LXIX, LXXI, LXXII.

These Articles do not bear out the present jurisdiction in mixed suits, or in the cases of crimes committed upon the person or property of any 
(2) Upon agreement with other nations to whom similar privileges have been allowed; such agreement being sanctioned by the Porte. (See the French Capitulations, A.D. I740, Article LII ; Miltitz, tom. ii, part 2, p. 127.)

The persons in behalf of whom it is allowed, are-

I. British subjects properly so called ${ }^{1}$.

2. Subjects of other Powers who navigate under the flag, or claim the protection of Great Britain.

The subject-matter of the jurisdiction includes either generally and constantly, or in some places and occasionally-

(I) Crimes and offences of whatever kind committed by British subjects ;

(2) Civil proceedings where all parties are British subjects;

(3) The same where the defendant is a British subject, and the plaintiff a subject of the Porte;

(4) The same where the defendant is a British subject, and the plaintiff subject to another European Power.

The recognized officers for its exercise are the ambassadors,

but British subjects; nor, indeed, if strietly constined, do they eonvey any eriminal jurisdiction at all.

Article XVIII, however, places Great Britain on the same footing as other faroured Powers, and thus extends the jurisdietion; but unless we can thus obtain the advantage of the Russian Treaty of Adrianople, A. D. 1829 , it does not appear that an exclusive criminal and police jurisdietion, except in eases where British subjects alone are eoncerned, ean be maintained under the Capitulations.

An extract from this treaty is given by Miltitz, tom. ii, part 2, p. I330, and the grant thereby made is that Russian subjects shall be under ' the exelusive jurisdiction and police of the Minister and Consuls of Russia.' De Miltitz says in another place (ibid., p. 1445) that Austria is entitled ' comme toutes les nations Chretiennes,' to the advantages of this treaty; but this does not seem to be the case, at least as regards jurisdiction; and on this account, as well as because the practico of judging in eivil eases where Turkish subjeets are parties, is not sanctioned by the Capitulations, I have thought it right to mention usage as one of the grounds of the jurisdiction. I may add that many parts of the French, Anstrian, and earlier Russian Capitulations, as well as of our own, appear to be so vaguely worded, that without tho assistance of usage it might be diffeult to aseertain the senso of them. (Since this noto was written my attention has been called to the first Articlo of the Convention of 1838 , which, being posterior to the Troaty of Adrianople, must be lecld to incorporate its provisions in favour of Great Britain, and so to place tho subjects of the latter on the same footing as those of Russia.)

3 There does not appeas to be much exactness in the language of tho Capitulations on this head. The two elasses are sometimes identified and sometimes distinguished. For purposes of envenienee I have used the term 'British subjects' indifferently for both. 
Apr. VI. consuls, and other agents of Great Britain. In some cases they are entitled under the Capitulations to act alone, in others in assisting the Turkish magistrates, but in the latter cases also they are often allowed a sole authority.

The laws to which the jurisdiction, when separately exercised, is referred for its regulation, are not certainly defined.

Article XVI of the Capitulations points to 'the custom' of the English in the decision of 'any suit or other difference or dispute amongst the English themselves.' And in proceedings between the English and other Europeans the fortm rei is customarily allowed to entail the application of English law to the case of an English defendant, but (to omit for the present particulars which will be considered hereafter) a strict adherence to English jurisprudence has never been observed.

In cases where British agents act jointly with the Turkish magistrates their only duty seems to be that of preventing palpable oppression.

The foregoing sketch may suffice to give a general view of that part of the subject which is properly international-that is, which concerns the relations between Great Britain and the territorial sovereign of Turkey, as well as those between Great Britain and the other foreign Powers which have similar privileges in the Levant. And I will now pass on to what may be called the domestic portion of it ; in other words, to a consideration of the principles upon which the jurisdiction thus conceded from without has been accepted and exercised. Here too, however, there is an international question which requires consideration. It has been noticed above that the jurisdiction is allowed not only in favour of the British subjects properly so called, but also in favour of the subjects of other countries under the protection of Great Britain. In former times it appears ${ }^{1}$ that the Flemish merchants, and perhaps some others, were in this position; but at present I am not certain that any but the Ionian islanders are so circumstanced.

By the Treaty ${ }^{2}$ of 1815 the Seven Islands are declared an independent State, under the protection of Great Britain; and by the Constitutional Charter of $\mathrm{I}_{\mathrm{I}} \mathrm{7}$ it is declared that "the British Consuls in all ports whatsoever shall be considered to be the Consuls and Vice-Consuls of the United States of the Ionian Islands, and the subjects of the same shall be entitled to their fullest protection.'

In accordance with these conditions, the Ionians have enjoyed all the advantages of British subjects in the Turkish dominions; but no direct jurisdiction over them having been

1 Capitulations, Article XXXIII.

${ }^{2}$ Hertslet's Treaties, vol. i. p. 46 et seq. 
conceded by the legislature of the islands to the British ambassador's and consuls, this has hitherto been enforced (as I understand) only by the threat of withdrawing British protection, and cannot be considered to rest upon a safe or satisfactory ground. It seems, however, that no difficulty would occur in procuring an Act of the Ionian Legislature to regulate this point. And as the terms of such a law ought on every account to agree with the provisions to be made in respect of British subjects, I will hereafter advert to this more particularly, and now proceed to consider the character of the jurisdiction with reference to the constitution and laws of England.

According to De Miltitz ${ }^{1}$, the earliest traces that can be found of the establishment of an English consular jurisdiction abroad are those contained in royal charters of the fifteenth century. Of these, the first (A, D. $\left.\mathrm{I}_{4} \mathrm{O}_{4}\right)$ recites the disorders which had arisen amongst English traders in the Hanse ports, and gives them power to elect Gubernatores, to whom the King grants quantum in nobis est anthority to govern the English merchants; and do full and speedy justice amongst them in their causes and disputes; to compose differences between them and the local merchants; to cause satisfaction to be made in cases of injury and violence to the latter, and to demand it in return ; also, with common consent of the merchants, to make statutes and ordinances, and to enforce them by reasonable penalties, \&c. And general obedience is enjoined upon English merchants, \&c. (Rymer's Focdera, ed. Lond., vol. viii. p. 360.)

This grant, from one part of it, appears to have been only a confirmation of an existing usage, founded upon privileges from the local Government, and upon consent of the merchants themselves; which privileges and consent are still treated as in some sort the basis of the jurisdiction, the Crown only lending manus suas adiutrices.

A similar charter of the Low Countries will be found, ibid., p. 46., A. D. 1407 , and again for Norway, ibid., p. 5rr, A. D. $1408^{2}$.

The letters-patent given to Lorenzo Strozzi by Richard III in ${ }^{4} 85$ are remarkable as not appearing to rest upon an antecedent grant of privileges from the country in which the consulate was to be established, but rather upon the general usage of nations. They contain, moreover, a direct creation of a royal magistracy, and subject to it not merchants only, but all the subjects of the Crown of those parts. (Rymer, vol. xii. p. 270 ; ef. ibid., p. 3i4.)

1 Tom. ii, part 1, p. $3^{8} 5$.

${ }^{2}$ In 1490 extensive powers of self-government wero allowed by treaty to the Englislı merchants in Donmark and Norway.-Miltitz, tom. ii, part 2, p. 664 . 
Apr. VI. Of the sixteenth century I lave examined several grants of consulates, but they are so vague in their terms as to afford little assistance. (Rymer, vol. xiii. p. 353 ; ibid., p. 766 ; ibid., vol. xiv. p. 424.)

In that century, too, the practice of creating corporations with exclusive privileges of foreign trade, appears to have been on the rise; and, as I shall presently have occasion to observe, the constitution of these bodies was such as to render unnecessary a frequent resort to judicial authority in the sense in which we have now to consider it.

As to the Levant, in particular, I have already noticed that the first formal Capitulations with the Porte bear date in the year ${ }^{1579 .}$ In ${ }_{158 I^{1}}$ it appears that the Queen established a Levant Company, but probably not with the same privileges as those subsequently granted by King James.

The commission to her ambassador or agent in the 'partes of 'Turkie' of the year ${ }^{5} 5^{82}$ has been preserved by Hackluyt ${ }^{2}$; and by that instrument, after having previously recited her treaty with the Porte, the Queen grants to him, inter alia, power over all her subjects trading in the Mussulman Empire, authorizes him to make laws for their guidance, and to enforce the observance of them, promising bonâ fide et in verbo Regio, to ratify all the ambassador might do a legibus nostris non abhorrentia.

Under this commission ${ }^{3}$, which contains a clause respecting consuls, the ambassador in ${ }_{5} 53$ named one for Aleppo, \&c., to whom he gave power 'to imprison, punish, and correct, \&c.,' even as he might himself do, by virtue of Her Majesty's commission.

In James I's time a new charter was granted to the Levant Company, and this, confirmed by Charles II, and recognized by various Acts of Parliament, constituted the basis of the British consular jurisdiction in the East, until the abolition of the company in 1825 .

By King James' letters-patent", the company was invested

1 See Miltitz, tom. ii, part 2, p. 780 , note 4.

${ }^{2}$ It is given by Miltitz, tom. ii, part 2, lib. 3, App., p. I602.

${ }^{3}$ Miltitz, ibid., p. 1604.

${ }^{4}$ The consuls and vice-consuls of the company might be appointed 'in all such places of the Seignory of Venice, the dominions of the Grand Seignior, and other places within the Levant,' as the company should think meet, and were to have authority and power to govern all and singular merchants, being subjects, \&c., as well of the said company as others which were not of the said company, \&c.-Charter, sec. 17 .

The company was also empowered 'to make, ordain, and establish, \&c., as well for the good rule and govermment of the said governor and company, \&c., as of all and singular others the subjects of him, his heirs 
with exclusive privileges of trade in great part of the Levant or Mediterranean seas, and (as it seems) with a general power of making by-laws, and appointing consuls, with judicial functions, in all the regions so designated.

Of this charter, and the confirmatory one of Charles II, the points which it seems most material for our present purpose to observe are:-

I. That it was altogether in the nature of a prerogative grant from home, and not at all founded upon any recital of concessions made by the various sovereigns in whose dominions it was to take effect. On the contrary, it assumed a power to withdraw British subjects from the foreign tribunals of its own authority, and, for aught that appears, even in cases in which those tribunals might, according to the local law, supply the legitimate forum. It was provided, indeed, that there should be no infraction of treaties, but that was all.

2. That the main strength of the coercive jurisdiction given by the charter appears, in Turkey at least, to have depended, on the one hand, upon the corporate character of the company and the power which it thus had over its own members, and on the other, upon its exclusive privileges of trade, which enabled it to prevent the influx of disorderly merchants and seamen.

3. That the charter did not contemplate the exercise of any criminal jurisdiction, properly so called, nor yet any of a civil character in mixed suits.

These branches of the jurisdiction have probably been of gradual acquisition, and perhaps were not pretended to in those times.

This charter, the principle of which, as to exclusive rights of trading, received support from the famous case of the East India Company v. Sandys (State Trials, vol. x. p. 37r), received also a Parliamentary recognition in the Act 26 Geo. II, cap. 18 ; but that statute, in confirming, with certain modifications, the

and successors, intermeddling, or by any means exereising merchandize, in any part of the Scignory of Venice, \&e., and to ordain, limit, and provide such pains, punishments, and penaltiss, by imprisonment of lody, or by fines or amerciaments, or by all or my of them, to be extended upon and against all and every offonders, \&c.'-Ibid., see. I9.

The exclusive privileges of trading extended 'to the Seignery of Venice, the Gulf of Venice, the State of Ragonsa, and any other State of Government within the Gulf of Venice, the dominions of the Grand Seinior, and every other part of the Lovant or Mediterranean seas,' "xcept the particular parts and places specified by the charter, and the coasts of Spain, France, and Tuscany, generally; but the legislative and judicial powers of the company and its consuls seem to have had no such limitation. 
Apr. VI. company's power of making by-laws, seems to have restricted their effect to the members of the company only.

There can be little doubt but that the Act 6 Geo. IV, cap. 33 which transferred the jurisdiction to the consuls of the Crown, was designed to establish it in their hands at least to the extent thus described.

But upon the dissolution of the company, a far more difficult task was thrown upon the consuls than that which their office had previously entailed. The whole corporate and preventive authority which had before supported them was gone, and the prescriptive respect, which might formerly have attached to the power's conferred by the charter, was disturbed by the necessity which had now arisen of testing them by the recognized principles of the constitution.

In 1826 doubt was thrown upon the legality of the general powers of fine and imprisonment, and of the power in certain cases of sending back His Majesty's subjects to this country, which had previously been thought to be vested in the consuls; and thus the coercive character of the jurisdiction was greatly shaken.

The Act 6 Geo. IV, moreover, had made no provision in lieu of the company's power of framing by-laws, nor had any principle been laid down by which the difficulties attending alike upon a strict adherence to English jurisprudence and upon deviations from it, by the consular tribunals, might be remedied.

And, lastly, the criminal and international jurisdiction had gradually assumed a form which the new state of affairs rendered in the highest degree important, but the exercise of which could not be based even upon that degree of authority which a reference to the powers of the company's consuls might in other respects have supplied.

It was to relieve the servants and subjects of the Crown in the Levant from the danger and inconvenience arising out of these circumstances that, in 1836 (eleven years after the dissolution of the company), the Act 6 \& 7 Will. IV, cap. 78 was passed; but up to this day its provisions have remained dormant; and the following observations induce me to think that, upon the passing of a new Act, the total repeal of it is desirable:

I. It will be remembered that although Queen Elizabeth's commission to her ambassador had based her power in the Levant, to some degree at least, upon the capitulations of the Porte, the charter of the Levant Company proceeded altogether upon the prerogative of the English Crown.

The Act 6 Geo. IV, cap. 33, in transferring the authority of the company's consuls to those of the King, recognized the charter and the subsequent Acts of Parliament as the chief basis of the 
jurisdiction; and though the language of section 4 is sufficient, Arr. VI. and was perhaps designed to include the authority derived, whether by capitulation or usage, from the Porte and other foreign Powers, no specific mention is made of it.

This omission must. I think, be deemed erroneous, since it is admitted on all hands that the law of nations does not countenance the assertion of such a jurisdiction upon the sole authority of the extra-territorial Power. But the Act now under consideration appears to have gone into the other extreme. As originally framed, it contained no allusion to the origin of the jurisdiction, but in consequence, I beliere, of the objections which had been taken to a Bill for similar purposes in China, the present preamble was added.

Now, this preamble omits all reference as well to the company's charter and the Acts relating to it, as to the Act 6 Geo. IV, cap. 33, and recites, apparently as the sole ground of the jurisdiction, the treaties and capitulations between His Majesty and the Porte; while, by speaking of it as ' a full and entire jurisdiction and controul conferred upon the British ambassadors and consuls,' by those capitulations (which are in the form of grants from the Porte), it seems to countenance the theory which has sometimes been put forward, but which English lawyers have refused to admit, that the ambassadors and consuls are in this respect delegates of the Porte, so that 'all their acts are to be considered as emanating from the Local Government whose representatives they are.'

It is true, indeed, that the subsequent part of the Act, by. proceeding to define and establish the jurisdiction, brings in British authority to complete it, and so, by construction, both the sources of the consular jurisdiction may be said to be acknowledged. But as I conceive it to be of great practical importance that some definite theory should be recognized by the constitution as applicable to all cases of the kind, and as this Act, even when most farourably construed, cannot bo said distinctly to propound such a theory, I think that its continuance on the Statute Book is on this ground alone undesirable.

2. The second objection to which the preamble seems open is that, by referring specifically to the capitulations, and to cases in which British subjects are exclusively concerned, it tends to discredit those important parts of the jurisdiction which have arisen from usage, or which relate to cases in which foreign subjects under the protection of Great Britain are involved. And this view (except as regards civil suits in which British subjects and the subjects of other Christian Powers are concernerl), is confirmed by the enacting part.

I am indeed aware of the difficulties which would have 
APr. VI. attended either a specific recital of the whole subject-matter of the jurisdiction as it practically exists, or the subjection (without their previous consent) of the Ionian islander's to a British Act of Parliament; but I think that by the use of general terms, all that is necessary in these respects might have been provided, without giving any cause for jealousy or offence.

3. I am in some doubt as to the nature of the powers conferred on the Crown by the Act. If they are meant to be, properly speaking, legislative, the proviso as to 'penalties, forfeitures, or imprisonments, for the breach of the directions and regulations' so made, appears to limit the criminal legislation to a very subordinate part of that 'full and entire jurisdiction and controul' which the Porte has conceded, and leaves the chief difficulties still unprovided for. But I conceive that the 'directions and regulations' authorized by the Act must be construed to relate rather to rules of practice and modes of proceeding than to legislation properly so called; and, if this be so, the question what laws or modifications of laws are to be considered applicable, remains as it was before the passing of the Act.

Having traced out the Turkish jurisdiction, I propose now to refer briefly to other provisions on the same or similar subjects.

With the Barbary States of Morocco, Tripoli, and Tunis there are separate treaties ${ }^{1}$ still in force, which, although not recited by the Act $6 \& 7$ Will. IV, may have been partly the cause of these States being included in the provisions of that statute.

As to the practice in those parts, it is not necessary for $\mathrm{my}$ present purpose to do more than observe that the jurisdiction, as defined by the treaties, bear a general resemblance to that established by the capitulations with the Porte.

In China a species of government and the erection of a criminal and admiralty jurisdiction was authorized by the Act 3 $\& 4$ Will. IV, cap. 93, sec. 6 , before any formal consent had been obtained from the Emperor. A Bill subsequently introduced into Parliament was lost, as I understand, owing to objections founded on this want of consent; but by the pending negotiations provisions will probably be made in this respect which will produce a state of things similar to that which exists in the Levant.

The British settlement at Honduras (of which I shall have occasion to speak again hereafter) presented in its original form the picture of a similar jurisdiction. Honduras ${ }^{2}$ was in 1768 lield to be part of the Spanish territories by Mr. de Grey (Reeves,

1 See Hertslet's Treaties, vol. i, \&c. Tripoli and Tunis are also included in those with the Porte.

${ }^{2}$ In 1699 it had been spoken of by the Attorney and Solicitor-General as 'being no part of His Majesty's plantations.'-Chalmers' Opinions, 2. 265 . 
p. 96); and in 1817 the Act 57 Geo. III, cap. 53, recited its existence as 'a settlement for' certain purposes in the possession and under the protection of His Majesty, but not within the territory and dominion of His Majesty.' But from an early period the British settlers appear to have had, by sufferance, a separate jurisdiction; and the Act 59 Geo. III, cap. 44, authorized the establishment of a Criminal Court amongst them. It would seem, however, that Honduras has now assumed a more formally colonial position.

In other foreign countries traces of the old consular power are also to be found ${ }^{2}$, but for the most part it seems from the treaties to be confined to voluntary jurisdiction in testamentary matters, and hardly ever to extend beyond arbitration.

I am unable, however, to speak with any certainty upon this head, since the subject requires much investigation, and a knowledge, not of written treaties only, but of the usages of the respective countries.

But whether any other important jurisdiction of this kind may at present exist or not, it is plain that intercourse between Christian and infidel, civilized and barbarous nations, must at all times tend to create them; and it seems, therefore, but prudent that a country whose colonial and commercial relations are so extensive as those of Great Britain, should be provided with settled principles by which to decide every new case as it may arise.

The ascertainment of these principles forms the next subject of my inquiry ; and here the chief point to be considered is, to what doctrines of the constitution the acquisition and exercise of such a jurisdiction can be referred.

Now, from the instances before adduced, both in respect of the Levant and other places, it may be concluded that in earlier times the Crown alone would have been thought to possess sufficient authority to establish Consular Courts wherever foreign Powers might allow them to exist; and it is remarkable ${ }^{2}$ that as late as the middle of the last century the Commission of the British Consul at $\Lambda$ licante contained a grant of judicial powers.

1 Seo Hertslet's Treaties, vol.i.p. rgI ; vol. ii. pp.3, 4, I54; vol. iii. p. 47 ; vol. iv. pp. 39, 40 ; vol. v. Pp. 292, 387, \&e.

${ }^{2}$ See Beawes' ed. Chitty, vol. ii. p. 4 I8. I lave seon later forms for tho same plaee to the same effect. In 1718 the $\Lambda$ ttorney-General (Thomson) appears to have thought that the Crown could givo a consul coercive powers (Clialmers' Opinions, 2. 29.). The ease of Waldron v. Cuombe, 3 Taunt, 162 , secms to be an athority against the judicial character of consuls.

The registers of the Privy Council might probably throw light upon the question, but I have not had loisure to examine them. 
Apr. VI. How far the practice of introducing such clauses may have prevailed in other cases, and when it ceased, I do not know ; but the present form of commission certainly does not pretend to convey such powers, and though this may in some degree be accounted for by the alterations which have been made in later treaties with regard to consular authority, yet, on the whole, it might be dangerous in these days to rely upon the prerogative, unless fortified, not by treaty only, but by some definite Parliamentary recognition.

Such a recognition, however, may, I think, very justly be claimed, even upon the present theory of the Constitution, and, as I shall endeavour to show, is urgently required by the public interest.

There are two principles which I may mention, in the first place, as having some relation to the question, but upon neither of which it is necessary, nor, as I think, expedient, to rely.

The first is that which concerns the general allegiance of the subjects, and the power of the Crown to restrain them from going abroad and to recall them home.

The second is that which has at various times been asserted and allowed in respect of restraints on English trade to foreign countries.

Of these, the former is, I think, inadequate; the latter, even if it could nowadays be maintained, would be so chiefly by a forced application to it of principles, the support of which we may obtain in this case by a more direct and legitimate way. The difference between the question of commercial prerogative and that which we have to consider may be illustrated by the following remarks.

Trade amongst nations is a thing necessarily incident to their mutual wants, and as far as it does not interfere with the respective internal interests of the comtries between which it takes place, may be argued to be in its own nature common and free, and, in fact, to be recognized as such by our constitution.

And, therefore, although the Crown, by its prerogative of peace and war, may exercise considerable influence in establishing a foreign trade, yet it may be argued to do so merely by the removal of unjust imperliments to the right, and not by the creation of the right itself. And such, in effect, appears to be the answer ${ }^{1}$ which has been given to the principle adopted in The East India Company v. Sandys, and more recently in a very able opinion by Mr. West. (See Chalmers' Opin., 2. 249.) But the exercise of legislative and judicial powers within an independent State is an attribute of sovereignty, the communica-

1 See Chitty on The Prerogative, chap. $\mathrm{x}$, sec. $\mathrm{I}$; the arguments in East India Company v. Sandys, \&c. 
tion of which is neither generally required by any international principle of justice or convenience, nor, except under peculiar circumstances, consistent with the dignity and safety of the Power which grants it. The foreign Power, therefore, which is induced to make a concession of this kind, performs a very different act from any of those which relate merely to the freedom or security of trade. It does, not thereby remove impediments to what, in a popular sense, may be termed the rights of other nations, but it trenches directly upon its own, and that in matters of the utmost delicacy and importance.

And so, on the other hand, the Crown, when it procures the allowance of this jurisdiction, eannot be considered to obtain privileges over which the subjects have any antecedent constitutional claim. On the contrary, it is in the strictest sense a creation by the Crown of that which the subjects cannot pretend to, nor, even when granted, acquire to themselves; for, allowing that a mere exemption from the local courts might be argued to be a personal privilege in them, it is plain that the erection of other courts implies sovereignty of such a kind as no subject, or body of subjects, except in the right of the Crown, can obtain.

The objections then which might in these days be raised to an assertion of the prerogative in the regulation of foreign trade do not seem to touch our case, of which the true principle (as I hope the following remarks will show) is still to be found among the recognized attributes of the Crown.

Let us assume that by the pending treaty China concedes an island, and that by the same treaty she concedes a jurisdiction over British persons and causes within her own ports.

How are these two cessions distinguishable? As it would appear, only by ?is: 'that the former is supported by the natural and most secure, but not the only basis of jurisdiction, viz. territory, and the latter is without it.

In both cases the Emperor parts with his sovereignty ; in both cases Great Britain acquires it. The difference between them is not so much one of kind as of degree and strength. In the island our authority extends to everything not specially oxcepted in the cession; on the continent we have also power, but only in excepted instances. In tho island wo can command physical force to give effect to the jurisdiction; on the continent we have an equal right to mako it effectual, but we may need foreign assistance to do so. In the island the territory lelps to maintain itself, and by a maintenance of the territory we maintain the jurisdiction ; on the continent our arms and negotiations may effect the same result, only they have a less secure basis of operation. 
Apr. VI. But if the nature of the thing ceded, the means of its acquisition and retention, and the party acquiring, be the same in the one case as the other, how can we escape the conclusion that both jurisdictions are held in the same right and under the same constitutional principles? And if this be so, then the sole prerogative of the Crown needs no further argument for its support.

For it is admitted on all hands, that when the Crown acquires territory, either by cession or conquest, its authority is purely monarchical; and if extra-territorial jurisdiction, acquired in a similar manner, be not distinguishable from territorial, except by a still greater dependence upon the continued exercise of the prerogative, it would seem at once to follow that both in a legislative and judicial sense it appertains properly and exclusively to the Crown.

Nor is it any objection to this view to say that the case of English subjects proceeding to a foreign country has in it features of that kind of colonization which is held to imply the applieation of the common law of England, to the exclusion of the legislative anthority of the Crown; for even if it could be maintained that these principles are not, practically speaking, subject to great modifications in the very case of settlements within a new and unoccupied territory, still it would be hard to see how they could find any entrance here. When British subjects proceed, in ordinary cases, to the dominions of a foreign Power, they go under the full operation of the principle which requires obedience to the local courts and laws. Then a treaty, or tacit agreement, ensues ${ }^{1}$, and a separate jurisdiction is provided for them ; but if English laws become applicable in its administration how is this effected? Surely not because the subjects brought those laws with them, for at first there was a local system which excluded their effect. It must be then from the treaty or agreement alone that they derive force; and, if so, they cease to be the laws of England in a proper sense ${ }^{2}$, and become merely that system of jurisprudence which either the treaty has stipulated for, or the Crown has thought fit to prescribe.

To test this view by a case which may easily occur. Let us suppose an English mercantile establishment to have acquired, in a foreign country, courts of its own and a certain application of English law, by mere usage and without any indirect interference from home.

1 I have supposed this to supervene, which is usually the case; but the principle must, I think, be the same though it precede, as now in parts of Clina.

2 The theory of the common law, as to the reception of the civil and canon law in England, illustrates this principle. 
Let us then imagine a conquest or cession by which the territory comes to the Crown. What would, under these circumstances, be the position of the English? Would they be able to allege an established constitutional right, and require to be treated as the inhabitants, not of a Crown colony, but of a settlement by emigration? If they did so, surely the answer would be this:- We cannot acknowledge that you ever were yourselves sovereigns, and if you now claim, independently of the Crown, you must rely upon a delegation from the former Government, and that Government, with all its dependencies, is at an end; but if you claim under a constructive authority from home, in what part of the constitution, except the prerogative of the Crown, can you find any principles which will bear upon that original surrender of sovereignty by the local power which must be the necessary basis of your claim? Either then the jurisdiction over you has now for the first time become British, and, if so, you are in the same pasition as the other inhabitants of the ceded district, or else you must be considered to have been the subject of a prior cession; and in both cases your constitutional rights are the same'".

1 The case of Honduras, which I have already had occasion to notice, fresents facts similar to those which I have here supposed. The following account of it is ehiefly taken from Clark on Colonial Law, p. 326, and Martin's Colonies, vol. ii, and, though not very aecurate, may suffice to show the resemblance. In its origin a trading establishment on foreign territory, it seems for many years to have existed without any direet government by the Crown, and yet independently of the territorial sovereign. Under these circumstanees, the inhabitants themselves formed an assembly for the enactment of laws, and in the courts the law of England, except where local circumstances prohibited its applieation, seems usually to have prevailed. In 1765 (apparently for the first time) the direet authority of the Crown was admitted and established by a formal covenant with the naval eommander on that station. Since this period the power of a governor seems to have been exercised by tho commanding officer of the station till, in 1783 , the practice of appointing superintendents commeneed.

The reeupation has at various periods been sanctioned by Spain, but with a reservation of the sovereignty, and ( 783 or 1786 ) with a proviso which has not been enforced, that no system of government should be established except by eonsent of both tho Crowns. Mr. Martin would now have tlie rights of Great Britain to be territorial, and to rest either upon cession or conquest; but the transactions upon which ho rolies were anterior to the $\Lambda$ ct 57 Geo. III, cap. 53, which, as I have abovo noticerl, disclaims territorial rights. The next $\Lambda$ et, however, 59 Gico. III, eap. 44, though eautiously worded, seems to have proceeded upon tho supposition that lhere was enough of a torritorial character to support the establisliment of a criminal court; but then this is no more than has since been done in China, and may be explained by tho necessity of 
APr. VI. In the last illustration which $I$ have used, it will be observed that $I$ have put the ease as strongly as possible against the prerogative, by supposing that there has been no direct grant of jurisdiction to the Crown from foreign Powers. But in the case of the Levant, at least, this is plainly otherwise, since the Capitulations are between the Porte and the Crown, and the jurisdiction is vested expressly in the ambassadors and consuls, who, whether appointed through the Levant Company or immediately by the Queen, must be considered as royal officers.

It will be observed also that in arguing the question $I$ have supposed a claim of right by the subjects in opposition to the Crown, and this seemed necessary fully to bring out the principle. But as a matter of fact, the real interests of the subjects are not only compatible with, but require this view of the prerogative.

The transition from mere residence to occupation, and from long occupation to territorial settlement, are so gradual, and there appears to be now so little authority which will apply to the case of subjects abroad, until the last step in the process is completed and a formal colony established, that it is of the utmost importance to seize upon any principle which will prevent confusion, and so tend to the protection of trade.

To establish by Act of Parliament any system sufficiently extensive and various to meet every case as it may arise is utterly impossible; and, indeed, the Act 6 \& 7 Will. IV, eap. 78 , by referring the regulation of the Levant jurisdiction to the King in Council, admits this impossibility.

To confer upon the Crown by Act of Parliament any powers short of those which I recommend, is but to shift the ground of the difficulty, since, of course, that which the Act has not

the case. Appeals, however, are said to be admissible from Honduras to the Privy Council; and the Act $3 \& 4$ Will. IV, eap. 54, sec. I4 las brought it within the privileges of the Navigation Acts. To this curious state of circumstances $I$ am not aware that auy definite theory has been applied.

The resort to Parliament for the erection of a court certaiuly shows that the power of the Crown was thought insufficient for the exercise of what was at that time acknowledged to be an extra-territorial juris. diction; but $I$ do not deny that the doctrine of the prerogative which I advance has been greatly neglected. And therefore, although Mr. Clark throws doubt upon the validity alike of the laws and tribunals other than those established under the Act of Parliament. I am inclined to maintain an opposite opinion.

To the covenant of the inhabitants, indeed, I can attach no constitutional effect, but, considered upon the principles which I lave advanced, the jurisdiction, whether territorial or extra-territorial, finds a support in the prerogative of the Crown, which is sufficient to establish both the political and the judicial institutions of the settlement. 
specified, because it was unforeseen, an Order in Council dependent upon the Act could not regulate.

Indeed, a brief review of the jurisdiction in the Levant alone will prove that none but the most flexible and extensive powers are adequate to its control.

The persons in favour of whom it exists are not Englishmen only, but also foreigners from Crown colonies, and not these foreigners only, but also Ionian islanders.

Nor is this all : it is to be exercised in cases where Turks, Germans, Frenchmen, Russians, Italians, \&c., are concerned as plaintiffs or prosecutors.

Lastly, it is held upon a precarious tenure; its limits are not strictly defined; it is sometimes shared with the Turkish magistrates, and it is to be exercised under continual relations with monarchical or absolute Powers ${ }^{1}$, and in dependence upon their support.

Under these circumstances it is not surprising that though the treaties point vaguely to the English 'custom,' the 'Turkey merchants should say that it is quite obvious that British law is totally inapplicable to the local circumstances of Turkey, and that all who reside in the Levant, though tenacious of the valuable privileges conceded by the Porte, are sensible of the necessity of a peculiar code of regulations for the government of Her Majesty's subjects within the Ottoman Dominions.

In truth, even if the variety of origin which distinguishes the persons protected by Great Britain did not render great modifications of English law both necessary and just, the points of contact with other Christian nations, as well as with the Turks,

I I cannot refrain from quoting Lord Chief Justice Jefferies' observation in the East India Company v. Sandys :-

'It hath been too much practised at this and other bars in Westminster Hall of late years to captivate the lay-gens by lessening the power of the King, and advancing, I had almost said, the prerogative of the people; and from hence come the many mischiefs to the King's subjects in parts abroad, by making the power of the King thought so inconsiderable, as though he were a mere Duke of Venice, being absolutely dependent upon his Parliament. Would it not be mightily for the honour and dignity of the Crown of England, think ye, that the Emperor of Fez and Moroces, or any prinee of the remoto parts of the world, should be told that Mr. Sandys, one of the King of Great Britain's subjects, came into the emperor's territories against his prinee's consent; and that he had no power to hinder him, unless he would consult with all his nobles and the representatives of all his common subjects, to assist therein; would not the emperor believe Sandys to be the greater prince of the two?' (Stute Trials, vol.x. p. 535). The Turks must have some such feeling when they find that criminals eannot be banished or executed, owing to tho constitutional weakness of our consular jurisdiction. 
APr. VI. would present continual difficulties. The present society may be exactly described in the words of an old author, when speaking of a similar state of things in the middle ages. 'It often happens that five men, each under' a different law, may be found walking or sitting together' .

It does not appear how the conflict of laws which in those times must have been continually caused, was provided for ; but in the Levant nothing except the general similarity of the commercial systems of Europe, and, on the part of England, a considerable forbearance in requiring the observance of her own peculiarities, could have prevented the occurrence of perplexities which the consular tribunals would hardly have been competent to solve.

But to meet the case fully, and to secure that there shall be sub diversitate iudicum una iustitia ${ }^{2}$, a further progress in the same direction is necessary.

In fact, the object which it appears to me should be aimed at is the formation of one system of jurisprudence for all the Europeans in the Levant, by which means the international questions would be reduced to a conflict between Turkish and Christian law, while even this would probably by degrees give way, or be modified, by the influence, thus consolidated, of the latter.

Of course, in pointing at this result, I do so rather to mark what should be the tendency, than what ean be hoped for as any immediate effect of our own legislation or of our negotiations with other Christian Powers; but to enter upon this course at all seems to require nothing less than what I have urged, viz. the free use of prerogative.

Upon these arguments, then, I found my first and most important recommendation, viz. that all extra-territorial power should be declared by Parliament to be held by the Crown as fully, and in the same right as its territorial power in ceded or conquered dependencies.

My next point is that great latitude should be allowed by the Act in its description of the means by which the jurisdiction has been, or may hereafter be, acquired, and of its extent and nature. In describing the Levant jurisdiction I have mentioned treaties or capitulations with the Porte, usage sanctioned by that Power, and agreement with other Christian Powers, as concurring to form its basis; and to these we must add the intended grant from the Ionian Legislature.

All these means of acquisition, therefore, should find room in

1 Cited from Savigny by Story, Conflict of Lau's, p. 4, note.

3 Cassiodorus, cited by De Miltitz, vol. i. p. IGa. 
the Act; and, indeed, as the question is one which admits of infinite variety, and relates principally to the rights of foreign Powers, which they are as competent to guard as they are to prevent the seizure of their territory, the language should be very general, and only so far limited as to avoid the appearance of sanctioning usurpation or aggression.

The object of these two suggestions may, perhaps, be attained by a preamble and enactment to the following effect:-

'Whereas, in divers foreign countries beyond the territory and dominion of the Crown supreme jurisdiction in respect of particular persons, causes, and things, has by treaty and other lawful means accrued to, and become vested in Her Majesty, her heirs, and successors ;

'And whereas doubts have from time to time arisen as to the exercise of such jurisdiction, and it is expedient to remove the same: Be it declared and enacted that in all cases in which there may heretofore have accrued, or may hereafter accrue, to Her Majesty, her heirs, and successors, or to any ambassador, consul, agent, or other person or persons in lier or their behalf, by treaty, capitulation, grant, sufferance, usage, or other lawful means, any jurisdiction or authority in respect of any persons, causes, or things, within any kingdom, state, or place beyond the territory and dominion of the Crown, it shall and may be lawful for Her Majesty, her heirs, and successors, to hold, exereise, and enjoy such jurisdiction or authority, according to the nature and extent thereof, and to perform all acts necessary and expedient for the due administration of the same, in as full and ample a manner as though such jurisdiction and authority were a territorial jurisdiction or authority acquired by cession or conquest from a foreign Power.'

To this declaration clauses to the following effect might be added :--

I. The repeal of section 4 of 6 Geo. IV, cap. 33 ; of $6 \& 7$ Will. IV, cap. 78 ; and of those parts of $3 \& 4$ Will. IV, cap. 93, which relate to jurisdiction in China; perhaps also of the article relating to Honduras.

2. A proviso that nothing in the Act shall be construed to authorize breach of treaties, \&c.

This, however, is only intended to prevent jealonsy, and it may appear disrespectful to the Crown.

3. A proviso that the places within which the jurisdiction is exercised shall not thereby be deemed possessions or plantations for any purpose of trade, naturalization, or the like. This too is, perhaps, an unnecessiry precaution, but under the novelty of the circumstances may be desirable.

4. A declaration that every law prescribed or sanctioned by 
Apr. VI. the Crown for cases within the jurisdiction shall be considered as the lex loci by the courts at home, equally with, but not so as to exclude the territorial law.

This appears to be a point of such importance that it ought not to be left to mere construction.

The jurisdiction might otherwise cause extreme confusion and hardship to the English residents.

Whether it should be extended to all cases, e. g. to marriages, is worth consideration, but I submit that it would be more convenient that it should.

5. An enactment that criminals of all descriptions may, at the discretion of the Crown, be sent to any of the British colonies for trial, and may there be tried, if necessary, upon written depositions, according to such forms and by such of the courts as Her Majesty may order.

This provision might be very important in China, and perhaps under some circumstances in the Levant. But though it would supply the expedient which has been proposed with regard to trials at Malta, yet I think there are several reasons for which, if possible, the judicial proceedings should be had at or near the foreign place where the erime has been committed.

These are (I) that this mode would give more satisfaction to the parties injured, and to the local authorities, who would thus be persuaded that there was a real intention to repress disorder.

(2) That the law of England is not the law of Malta, and therefore, even if the former were to prevail within the jurisdiction, cases under it could not be referred to a tribunal conversant with that law, and that the same objection would apply whatever law might be established in the Levant, in as far as it differed from that of Malta.

(3) That on the spot the evidence might be given orally which could not otherwise be provided, except at great expense and trouble, and in many cases might be impossible.

(4) That all the parties concerned in any particular crime might be tried together, by the same law and on the same evidence, which, in the very possible case of Ionians and Maltese being jointly guilty, could not be done, except by requiring the former to be sent to the English colony, which probably would cause jealousy and might be resisted.

The means by which a satisfactory local tribunal might be established I will mention hereafter.

6. A similar enactment as to carrying sentences into effect by execution, imprisonment, or penal labour within a British colony.

This would be open, in a great degree, to the first of the objections last stated, but not to the concluding remarks of the 
fourth, as sentences against Ionians might be carried into effect Apr. VI. within their own island.

7. A clause as to ressels of war, which perhaps might extend so as to require the assistance of the crews in cases of executions on shore, or even to providing for executions on board.

8. Clauses as to expenses, similar in some respects to those in the draft Act last referred to, but framed so as to meet the more general kind of jurisdiction here proposed.

To these provisions others would probably have to be added in framing the Bill ; but as I have said enough to give a general view of what is proposed, and as everything depends upon the decision which is come to upon the principle of jurisdiction, I have thought it unnecessary to go more into detail at present.

Supposing such an Act to have been obtained, I will give, briefly, an account of the measures which should, in my opinion, be taken to give it effect in the Levant ${ }^{1}$.

I. The Ionian Legislature should be moved to pass an Act putting their subjects upon the same footing as other persons within the jurisdiction, in all respects, except as to trial and punishment within a British colony; and the same should be done with regard to any other nation which enjoys British protection.

2. Communications should be entered into with other Christian Powers, having similar privileges in their own right, with a view generally to the assimilation of the jurisprudence, and particularly to that of proceedings in civil appeals ${ }^{2}$, and the execution of criminal sentences within the jurisdiction. Prisons common to all the Christian Powers might thus be established at a small expense to each, and provision might be made for carrying capital sentences into effect with order and solemnity.

Austria, from not having as yet established any particular code, would probably be found willing to enter upon these arrangements, and, except on the part of Russia perhaps, a feeling of identity of interest might induce the other Christian Powers gradually to combine with us. On this point, however, I speak merely from conjecture.

1 I am not sufficiently acquainted with the state of matters in China to offer any suggestions with regard to that quarter.

A Appeals from the decisions of French, Russian, Sardinian, and somo other commissions are earried to courts in those countries. This is evidently a hardship upon British subjects, and unless there should be any occasion for carrying appeals from British tribunals to the Privy Council at liome (which seems very undesirable), an effort should bo made to have this remedied. Tho original tribunals for mixed suits must also depend for their organization upon somo arrangemont witl foreign Powers. 
Arr. VI. 3. I hold it to be indispensable that one or more legal assessors should be provided for the assistance of the ambassadors and consuls.

Of these, one should reside at Constantinople, and assist at all criminal trials and appeals in civil suits. He should also make circuits or occasional expeditions for the purpose of trying the more serious offences elsewhere. From the extent of the jurisdiction, it would appear desirable that a similar officer should reside in Egypt; but provision for that country, and for the Barbary States, might perhaps be made by periodical visits of the Law Officers of the Crown from Malta or Gibraltar. Unless these officer's could receive some consular character, they should not possess any nominal jurisdiction, lest they should be thought to trench upon the authority of the ambassadors and consuls, which is that recognized by the treaties and usage; but their concurrence should in all cases be necessary to the validity of a sentence.

4. The civil jurisdiction should for the present be provisionally established according to the existing usage, both as to the application of laws and the forms of proceeding and appeala power of enforcing process by fine and imprisonment being given.

It might be well, however, at once to divide the appellate jurisdiction, so as to vest a portion of it in the Consul-General for Egypt. When the Consul-General decides in the first instance, the legal assessor might assume one or more of the magistrates afternamed to form a Court of Appeal. The respective Courts of Appeal might, with the advice of their legal assessor, be empowered to make rules of practice for all the courts within their limits.

5. The criminal jurisdiction should be divided into Courts of Magistracy and of Assize ${ }^{1}$, the former having the same kind of jurisdiction as magistrates have in England; the latter, the cognizance of more serious offences. The former, in cases which one or more magistrates can decide summarily at home, should be held by the consul alone. When the case is one which would go before quarter sessions at home, some of the principal residents should be associated with the consul, and should for that purpose receive commissions from the Crown, or the ambassador.

The Courts of Assize should be presided over by the consul, or consul-general, with the assistance of the legal assessor, and

1 The Courts of Magistracy might be defined by an Order in Council. A regular commission to the assistants, however, seems to me preferable to the system of assessorship there proposed. The office would probably be more valued, and its duties better performed, while the power of appointment might strengthen the influence of the Crown. 
though trial by jury might often be impracticable, and as a formal system is, perhaps, not to be desired under the circumstances, a certain number of the magistrates might be called in to assist, and might have votes as to matters of fact. The directions issued in the first instance to the legal assessors and consuls should be to decide criminal cases as nearly as may be according to the law of England '. Power to make rules of practice should be vested in the same hands as in civil cases.

The ambassadors should have power to pardon and to commute sentences.

Banishment from within the jurisdiction should be prescribed in certain cases.

Short imprisonments might be provided for on the spot. Those of a longer duration, in Malta, and for the Ionians, in the Ionian Islands. Transportation to the penal settlements might also be provided.

Capital sentences should, if possible, be carried into effect on the spot ${ }^{2}$.

These suggestions, however, I must observe are intended merely for provisional purposes, and that only in a general sense ${ }^{3}$. All permanent arrangements should, I think, be referred for consideration to the legal assessors, who, upon consultation with parties on the spot, and after some practical experience of the working of the system, might be required to furnish reports upon which ulterior legislation should proceed. The employment of these officers, as I have already said, appears to me absolutely indispensable, and I wonld humbly submit that the first step which Her Majesty's Government should take is to select some lawyer, if possible one who has had experience of practice in Gibraltar or Malta, for the office of assessor at Constantinople.

1 See the Order in Council for Canton (Hertslet, vol. iv. p. 84).

${ }^{2}$ It is of course very diffieult to say how this should be effected. I have already hinted at executions on board of vossels of war, but, except in cases of great necessity, I should be loth to recommend the imposition of so disagreeable a duty upon the navy. The Porte would probahly give assistance through its officers, and perhaps by virtuo of one of the Articles of the French Capitulations we are entitled to demand it. $\Lambda$ Macao the Portuguese exceute delinquents.

${ }^{3}$ 'The delay of practical measures until a formal codo should be proviclerl would be, in effect, an abandomment of the subject in despair. The course which I have recommended with regard to the appointment of legal assessors under provisional instruetions, besides meeting the inmediate necessity of the case, appears to me to furmish the most likoly means of eventually establishing a system of jurisprudence practically adapted to the nature of the juristiction. It seems, moreover, to bo sanetioned by the usage generally pursued in new colonies. 
Apr. VI. By putting into the hands of such a person the various consular reports and the Levantine codes, \&c., of foreign Powers, and by requiring him to point out the regulations which he may consider immediately necessary for his own guidance and protection, more would probably be effected towards a good commencement of the system than could be hoped for in any other way. His position, no doubt, would be at first a difficult one, but not more so, perhaps, than that of many judges who have had the first regulation of tribunals in conquered colonies; and a reference to the charters and instructions, under which such tribunals have been established, would afford him very considerable assistance.

6. It will be observed that I have made no recommendations as to the jurisdiction when exercised jointly with the Turkish magistrates; perhaps it may hereafter assume a shape which may require specific instructions, but at present $I$ do not see how any can be given.

There are many other points which have occurred to me in preparing these observations which are not noticed in them, and, doubtless, many more which ought to have been considered, but have escaped me.

My report, however, has already run to such a length, and there are such pressing reasons for a decision of the question to which it relates, that $I$ have preferred offering it in its present form to suffering any further delay to occur.

I shall, therefore, only add that no one can be more sensible than myself of the extent and difficulty of the question referred to me, or of the imperfectness of the manner in which I have treated it. Indeed, nothing could reconcile me to allowing this paper to pass into other hands but the knowledge that it is intended only for the private use of those who are amply competent to supply its deficiencies, and to correct the errors, whether relating to facts or to principles, which are to be found in it. 


\title{
APPENDIX VII
}

\section{FOREIGN JURISDICTION ACT', 1890 ,}

\author{
53 \& 54 VIст. с. 37
}

Section.

Arrangement of Sections.

I. Exercise of jurisdiction in foreign country.

App. VII.

2. Exercise of jurisdiction over British subjects in countries without regular governments.

3. Validity of acts done in pursuance of jurisdiction.

4. Evidence as to existence or extent of jurisdiction in foreign country.

5. Power to extend enactments in First Schedule.

6. Power to send persons charged with offences for trial to a British possession.

7. Provision as to place of punishment of persons convicted.

8. Validity of acts done under Order in Council.

9. Power to assign jurisdiction to British courts in cases within Foreign Jurisdiction Act.

ro. Power to amend Orders in Council.

Ir. Laying before Parliament, and effect of Orders in Council.

12. In what cases Order's in Council void for repugnancy.

13. Provisions for protection of persons acting under Foreign Jurisdiction Acts.

I4. Jurisdiction over ships in certain Eastern seas.

15. Provision as to subjects of Indian princes.

16. Definitions.

17. Power to repeal or vary Acts in Second Schedule.

18. Repeal.

19. Short title.

Schedules.

An Act to consolidate the Foreign Jurisdiction Acts '. [4th August I89o.]

Wilereas by treaty, capitulation, grant, usage, sufferance,

1 This repealed and conselidated with later $\Lambda$ ets the original $\Lambda$ et of I 843 ( $6 \& 7$ Vict. c. 94), which was passed in aceordance with the recommendations of Mr. Hope Scott's Memorandum, printed above in $\Lambda_{p} p$. VI. 
Arr. VII. and other lawful means, Her Majesty the Queen has jurisdiction within divers foreign countries, and it is expedient to consolidate the Acts relating to the exercise of Her Majesty's jurisdiction out of Her dominions:

Be it therefore enacted by the Queen's most Excellent Majesty, by and with the advice and consent of the Lords Spiritual and Temporal, and Commons, in this present Parliament assembled, and by the authority of the same, as follows:

Exercise of juristiction in foreign (rotintry.

Exercise of jurisdiction over British subjects in countries without regular governments.

Validity of acts done in pursuance of jurisdiction.

Evidence as to existence or extent of jurisdiction in foreign country.

Power to extend enactments in First Schedule.
I. It is and shall be lawful for Her Majesty the Queen to hold, exercise, and enjoy any jurisdiction which Her Majesty now has or may at any time hereafter have within a foreign country in the same and as ample a manner as if Her Majesty had acquired that jurisdiction by the cession or conquest of territory.

2. Where a foreign country is not subject to any government from whom Her Majesty the Queen might obtain jurisdiction in the manner recited by this Act, Her Majesty shall by virtue of this Act have jurisdiction over Her Majesty's subjects for the time being resident in or resorting to that country, and that jurisdiction shall be jurisdiction of Her Majesty in a foreign country within the meaning of the other provisions of this Act.

3. Every act and thing done in pursuance of any jurisdiction of Her Majesty in a foreign country shall be as valid as if it had been done according to the local law then in force in that country.

4. If in any proceeding, eivil or criminal, in a court in Her Majesty's dominions or held under the authority of Her Majesty any question arises as to the existence or extent of any jurisdiction of Her Majesty in a foreign country, a Secretary of State shall, on the application of the court, send to the court within a reasonable time his decision on the question, and his decision shall for the purposes of the proceeding be final.

(2) The court shall send to the Secretary of State, in a document under the seal of the court, or signed by a judge of the court, questions framed so as properly to raise the question, and sufficient answers to those questions shall be returned by the Secretary of State to the court, and those answers shall, on production thereof, be conclusive evidence of the matters therein contained.

5.-(I) It shall be lawful for Her Majesty the Queen in Council, if She thinks fit, by Order to direct that all or any of the enactments described in the First Schedule to this Act, or any enactments for the time being in force amending or substituted for the same, shall extend, with or without any exceptions, adaptations, or modifications in the Order mentioned, to any foreign country in which for the time being Her Majesty has jurisdiction. 
(2) Thereupon those enactments shall, to the extent of that Arp. VIL. jurisdiction, operate as if that country were a British possession, and as if Her Majesty in Council were the Legislature of that possession.

6.-(I) Where a person is charged with an offence cognizable by a British court in a foreign country, any person having authority derived from Her Majesty in that behalf may, by warrant, cause the person so charged to be sent for trial to any British possession for the time being appointed in that behalf by Order in Council, and upon the arrival of the person so charged in that British possession, such criminal court of that possession as is authorized in that behalf by Order in Council, or if no court is so authorized, the supreme criminal court of that possession, may cause him to be kept in safe and proper custody, and so soon as conveniently may be may inquire of, try, and determine the offence, and on conviction punish the offender according to the laws in force in that behalf within that possession in the same manner as if the offence had been committed within the jurisdiction of that criminal court.

Provided that-

(a) A person so charged may, before being so sent for trial, tender for examination to a British court in the foreign country where the offence is alleged to have been committed any competent witness whose evidence he deems material for his defence and whom he alleges himself unable to produce at the trial in the British possession:

(l) In such case the British court in the foreign country shall proceed in the examination and cross-examination of the witness as though he had been tendered at a trial before that court, and shall cause the evidence so taken to be reduced into writing, and shall transmit to the criminal court of the British possession by which the person charged is to be tried a copy of the evidence, certified as correct under the seal of the court before which the evidence was taken, or the signature of a judge of that court:

(c) Thereupon the court of the British possession before which the trial takes place shall allow so much of the evidence so taken as would have been admissible according to the law and practice of that court, had the witness been produced and examined at the trial, to be read and received as legal evidence at the trial :

(d) The court of the British possession shall admit and give effect to the law by which the allegerl offender would have been tried by the British court in the foreign country in which his offence is alleged to have been committed, so far as that law relates to the criminality of the act alleged to 
Apr. VII.

have been committed, or the nature or degree of the offence, or the punishment thereof, if the law differs in those respects from the law in force in that British possession.

(2) Nothing in this section shall alter or repeal any law, statute, or usage by virtue of which any offence committed out of Her Majesty's dominions may, irrespectively of this Act, be inquired of, tried, determined, and punished within Her Majesty's dominions, or any part thereof.

Provision as to place of punishment of persons convicted.

Validity of acts done under Order in Council.

Power to assign jurisdiction to British courts in cases within Foreign Jurisdiation Act.

Power to amend Orders in Council.

Laying before

Parliament, and effect of Orders in

Council.
7. Where an offender convicted before a British court in a foreign country has been sentenced by that court to suffer death, penal servitude, imprisonment, or any other punishment, the sentence shall be carried into effect in such place as may be directed by Order in Council or be determined in accordance with directions given by Order in Council, and the conviction and sentence shall be of the same force in the place in which the sentence is so carried into effect as if the conviction had been made and the sentence passed by a competent court in that place.

8. Where, by Order in Council made in pursuance of this Act, any British court in a foreign country is authorized to order the removal or deportation of any person from that country, that removal or deportation, and any detention for the purposes thereof, according to the provisions of the Order in Council, shall be as lawful as if the order of the court were to have effect wholly within that country.

9. It shall be lawful for Her Majesty the Queen in Council, by Order, to assign to or confer on any court in any British possession, or held under the authority of Her Majesty, any jurisdiction, civil or criminal, original or appellate, which may lawfully by Order in Council be assigned to or conferred on any British court in any foreign country, and to make such provisions and regulations as to Her Majesty in Council seem meet respecting the exercise of the jurisdiction so assigned or conferred, and respecting the enforcement and execution of the judgements, decrees, orders, and sentences of any such court, and respecting appeals therefrom.

10. It shall be lawful for Her Majesty the Queen in Council to revoke or vary any Order in Council made in pursuance of this Act.

11. Every Order in Council made in pursuance of this Act shall be laid before both Houses of Parliament forthwith after it is made, if Parliament be then in session, and if not, forthwith after the commencement of the then next session of Parliament, and shall have effect as if it were enacted in this Act.

12.-(I) If any Order in Council made in pursuance of this 
Act as respects any foreign country is in any respect repugnant to the provisions of any Act of Parliament extending to Her Majesty's subjects in that country, or repugnant to any order or regulation made under the authority of any such Act of Parliament, or having in that country the force and effect of any such Act, it shall be read subject to that Act, order, or regulation, and shall, to the extent of such repugnancy, but not otherwise, be void.

(2) An Order in Council made in pursuance of this Act shall not be, or be deemed to have been, void on the ground of repugnancy to the law of England unless it is repugnant to the provisions of some such Act of Parliament, order, or regulation as aforesaid.

13.-(I) An action, suit, prosecution, or proceeding against any person for any act done in pursuance or execution or intended execution of this Act, or of any enactment repealed by this Act, or of any Order in Council made under this Act, or of any such jurisdiction of Her Majesty as is mentioned in this Act, or in respect of any alleged neglect or default in the execution of this Act, or of any such enactment, Order in Council, or jurisdiction as aforesaid, shall not lie or be instituted-

(a) in any court within Her Majesty's dominions, unless it is commenced within six months next after the act, neglect, or default complained of, or in case of a continuance of injury or damage within six months next after the ceasing thereof, or where the cause of action arose out of Her Majesty's dominions within six months after the parties to the action, suit, prosecution, or proceeding have been within the jurisdiction of the court in which the same is instituted; nor

(b) in any of Her Majesty's courts without Her Majesty's dominions, unless the cause of action arose within the jurisdiction of that court, and the action is commenced within six months next after the act, neglect, or default complained of, or, in case of a continuance of injury or damage, within six months next after the ceasing thereof.

(2) In any such action, suit, or proceeding, tender of amends before the same was commenced may be pleaded in lieu of or in addition to any other plea. If the action, suit, or proceeding was commenced after such tender, or is proceeded with after payment into court of any money in satisfaction of the plaintiff's claim, and the plaintiff does not recover more than the sum tendered or paid, he shall not recover any costs incurred after such tender or payment, and the defendant shall be entitled to costs, to be taxed as between solicitor and client, as from the time of such tender or payment; but this provision shall not affect costs on any injunction in the action, suit, or proceeding. 
Apr. VII. 14. It shall be lawful for Her Majesty the Queen in Council to make any law that may seem meet for the government of $\mathrm{Hel}^{*}$

Jurisdiction over ships in certain Eastern seas.

Provision a to subjectis of Indian princes.

1)efinition:

Power to repeal or vary Acts in second Schedule. Relverl.

short title. Majesty's subjects being in any vessel at a distance of not more than one hundred miles from the coast of China or of Japan, as fully and effectually as any such law might be made by Her Majesty in Council for the government of Her Majesty's subjects being in China or in Japan.

15. Where any Order in Council made in pursuance of this $\Lambda$ ct extends to persons enjoying Her Majesty's protection, that expression shall include all subjects of the several princes and states in India.

16. In this Act-

The expression 'foreign country' means any country or place out of Her Majesty's dominions :

The expression 'British court in a foreign country' means any British court having jurisdiction out of Her Majesty's dominions in pursuance of an Order in Council whether made under any Act or otherwise:

The expression 'jurisdiction' includes power.

17. The Acts mentioned in the Second Schedule to this Act may be revoked or varied by Her Majesty by Order in Council.

18. The Acts mentioned in the Third Schedule to this Act are hereby repealed to the extent in the third column of that schedule mentioned: Provided that-

(I) Any Order in Council, commission, or instructions made or issued in pursuance of any enactment repealed by this Act, shall, if in force at the passing of this Act, continue in force, until altered or revoked by Her Majesty as if made in pursuance of this Act; and shall, for the purposes of this Act, be deemed to have been made or issued under and in pursuance of this Act; and

(2) Any enactment, Order in Council, or document referring to any enactment repealed by this Act shall be construed to refer to the corresponding enactment of this Act.

19.-(I) This Act may be cited as the Foreign Jurisdiction Act, 1890 .

(2) The Acts whereof the short titles are given in the First Schedule to this Act may be cited by the respective short titles given in that schedule. 


\section{SCHEDULES}

\section{FIRST SCHEDULE}

\begin{tabular}{|c|c|c|c|}
\hline $\begin{array}{l}\text { Session } \\
\text { and } \\
\text { Chinpter. }\end{array}$ & Title. & $\begin{array}{l}\text { Enactments } \\
\text { which may } \\
\text { be extended } \\
\text { by Order in } \\
\text { Council. }\end{array}$ & Short Title. \\
\hline $\begin{array}{l}12 \& 1_{3} \text { Vict. } \\
\text { c. } 96 .\end{array}$ & $\begin{array}{l}\text { An Act to provide for the Pro- } \\
\text { secution and Trial in Her } \\
\text { Majesty's Colonies of Offen- } \\
\text { ces committed within the } \\
\text { jurisdiction of the Admi- } \\
\text { ralty. }\end{array}$ & $\begin{array}{l}\text { The whole } \\
\text { Act. }\end{array}$ & $\begin{array}{c}\text { Admiralty } \\
\text { Offences } \\
\text { (Colonial) } \\
\text { Act, } 8_{49} \text {. }\end{array}$ \\
\hline $\begin{array}{l}\text { I4 \& } 15 \text { Vict. } \\
\quad \text { c. } 99\end{array}$ & $\begin{array}{l}\text { An Act to amend the law of } \\
\text { evidence. }\end{array}$ & $\begin{array}{l}\text { Sections } 7 \\
\text { and } 11 .\end{array}$ & $\begin{array}{c}\text { Evidence Act, } \\
185 \mathrm{I} .\end{array}$ \\
\hline $\begin{array}{l}17 \& \text { I } 8 \text { Vict. } \\
\text { e. 104. }\end{array}$ & $\begin{array}{l}\text { The Merchant Shipping Aet, } \\
\text { I854. }\end{array}$ & Part $\mathrm{X}$. & \\
\hline $\begin{array}{l}\text { I9\& zo Vict. } \\
\text { c. I } 3 \text {. }\end{array}$ & $\begin{array}{l}\text { An Act to proville for taking } \\
\text { evidence in Her Majesty's } \\
\text { Dominions in relation to } \\
\text { civiland eommereialmatters } \\
\text { pending before Foreign tri- } \\
\text { bunals. }\end{array}$ & $\begin{array}{l}\text { The whole } \\
\text { Act. }\end{array}$ & $\begin{array}{c}\text { Foreign } \\
\text { Tribunals } \\
\text { EvidenceAct, } \\
1856 .\end{array}$ \\
\hline $\begin{array}{l}22 \text { Viet. c. } \\
20 .\end{array}$ & $\begin{array}{l}\text { An Act to provide for taking } \\
\text { evidence in Suits and Pro- } \\
\text { ceedings pending before Tri- } \\
\text { bunals in Her Majesty's } \\
\text { Dominions, in places out of } \\
\text { the jurisdiction of such } \\
\text { tribunals. }\end{array}$ & $\begin{array}{l}\text { The whole } \\
\Lambda \text { ct. }\end{array}$ & $\begin{array}{l}\text { Evidence by } \\
\text { Commission } \\
\text { Aet, } 1859 \text {. }\end{array}$ \\
\hline $\begin{array}{l}22 \& 23 \text { Vict. } \\
\quad \text { c. } 63 \text {. }\end{array}$ & $\begin{array}{l}\text { An Act to afford Facilities for } \\
\text { the more certain Ascertain- } \\
\text { ment of the Lilw adminis- } \\
\text { tered in one Part of Her } \\
\text { Majesty's Dominions, when } \\
\text { pleadcal in the Courts of } \\
\text { another Part thercof. }\end{array}$ & $\begin{array}{c}\text { The whole } \\
\text { Act. }\end{array}$ & $\begin{array}{c}\text { British Law } \\
\text { Ascertain- } \\
\text { ment Act, } \\
1859 .\end{array}$ \\
\hline $\begin{array}{l}23 \& 24 \text { Vict. } \\
\text { c. 122. }\end{array}$ & $\begin{array}{l}\text { An Act to enable the Legisli- } \\
\text { tures of IIer Majesty's Pos- } \\
\text { sessions Abroad to mako } \\
\text { Enaetments similar to the } \\
\text { Enactment of the Act ninth } \\
\text { George the Fourth, cliapter } \\
\text { thirty-onm, section ejght. }\end{array}$ & $\begin{array}{c}\text { The whole } \\
\text { Aet. }\end{array}$ & $\begin{array}{c}\text { Admiralty } \\
\text { Offences } \\
\text { (Colonial) } \\
\text { Act, I 86o. }\end{array}$ \\
\hline
\end{tabular}




\begin{tabular}{|c|c|c|c|}
\hline $\begin{array}{l}\text { Session } \\
\text { and } \\
\text { Chapter. }\end{array}$ & Title. & $\begin{array}{l}\text { Enactments } \\
\text { which may } \\
\text { be extended } \\
\text { by Order in } \\
\text { Council. }\end{array}$ & Short Title. \\
\hline $\begin{array}{l}24 \& 25 \text { Vict. } \\
\text { c. II. }\end{array}$ & $\begin{array}{l}\text { An Act to afford facilities for } \\
\text { the better ascertainment of } \\
\text { the Law of Foreign Countries } \\
\text { when pleaded in Courts } \\
\text { within Her Majesty's Do- } \\
\text { minions. }\end{array}$ & $\begin{array}{c}\text { The whole } \\
\text { Act. }\end{array}$ & $\begin{array}{c}\text { Foreign Law } \\
\text { Ascertain- } \\
\text { ment Act, } \\
\text { r86r. }\end{array}$ \\
\hline $\begin{array}{l}30 \& 3_{1} \text { Vict. } \\
\text { c. 124. }\end{array}$ & $\begin{array}{l}\text { The Merehant Shipping Act, } \\
\text { I } 867 \text {. }\end{array}$ & Section 11. & \\
\hline $\begin{array}{l}37 \& 38 \text { Vict. } \\
\text { c. } 94\end{array}$ & $\begin{array}{l}\text { The Conveyaneing (Scotland) } \\
\text { Act, } 1874 \text {. }\end{array}$ & Section 51. & \\
\hline $\begin{array}{l}44 \& 45 \text { Vict. } \\
\text { e. } 69 .\end{array}$ & $\begin{array}{l}\text { The Fugitive Offenders Act, } \\
\text { r88r. }\end{array}$ & $\begin{array}{l}\text { The whole } \\
\text { Act. }\end{array}$ & \\
\hline $\begin{array}{l}48 \& 49 \text { Vict. } \\
\text { c. } 74 \text {. }\end{array}$ & $\begin{array}{l}\text { The Evidence by Commussion } \\
\text { Act, } 1885 \text {. }\end{array}$ & $\begin{array}{c}\text { The whole } \\
\text { Act. }\end{array}$ & \\
\hline
\end{tabular}

\section{SECOND SCHEDULE}

Acts which may be revolicd or raried by Order in Council.

S. 17. Session and Chapter.

Title.

Extent of Repeal. $24 \& 25$ Vict. c. 3 I.

An Act for the prevention and The whole Act. punishment of offences committed by Her Majesty's subjects within certain territories adjacent to the colony of Sierra Leone.

$26 \& 27$ Vict. c. 35. An Act for the prevention and The whole Act. punishment of offences committed by Her Majesty's subjects in South Africa. 


\section{THIRD SCHEDULE}

Enactments repealed.

\begin{tabular}{|c|c|c|}
\hline Session and Chapter. & Title or Short Title. & Extent of Repeal. \\
\hline 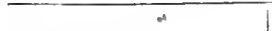 & & \\
\hline $6 \& 7$ Vict. c. 94 . & $\begin{array}{l}\text { The Foreign Jurisdiction Act, } \\
\text { I8 } 43 \text {. }\end{array}$ & The whole Act. \\
\hline $20 \& 2$ I Vict.c. 75 & $\begin{array}{l}\text { An Act to confirm an Order in } \\
\text { Council concerning the exer- } \\
\text { cise of jurisdiction in matters } \\
\text { arising within the kingdom } \\
\text { of Siam. }\end{array}$ & The whole Act. \\
\hline 28 \& 29 Vict. c. I I6. & $\begin{array}{l}\text { The Foreign Jurisdiction Act } \\
\text { Amendment Act. } 186_{5} \text {. }\end{array}$ & The whole Act. \\
\hline$=9 \& 30$ Vict. c. 87. & $\begin{array}{l}\text { The Foreign Jurisdiction Let } \\
\text { Amendment Act, } 1866 .\end{array}$ & The whole Act. \\
\hline $33 \& 34$ Vict. c. 55 . & $\begin{array}{l}\text { The Siam and Straits Settle- } \\
\text { mentsJurisdiction Act, } 870 \text {. }\end{array}$ & The whole Act. \\
\hline $3^{8} \& 39$ Vict. c. 85. & $\begin{array}{l}\text { The Foreign Jurisdiction Act, } \\
\text { I875. }\end{array}$ & The whole Act. \\
\hline $39 \& 40$ Vict. c. 46. & $\begin{array}{l}\text { An Act for more efiectually } \\
\text { punishing offences against } \\
\text { the laws relating to the } \\
\text { slave tradle. }\end{array}$ & Sections 4 and 6. \\
\hline 4 I \& 42 Vict. c. 67. & $\begin{array}{l}\text { The Foreign Jurisdiction Act, } \\
\text { I } 878 \text {. }\end{array}$ & The whole Act. \\
\hline
\end{tabular}




\section{APPENDIX VIII}

\section{EARLY CONSTITUTIONAL HISTORY OF THE AUSTRALIAN COLONIES}

Apr. VIII. Ix considering the constitutions of the Australian colonies it is useful to bear in mind the origin of the several colonies. Dates of New South Wales was founded in I788, the governor's comorigin. mission comprising not only the whole eastern littoral of Australia, but also Tasmania and New Zealand. Tasmania (then Van Diemen's Land) became a separate colony in 1825 , New Zealand in 1840 , Victoria in 1850 , Queensland in 1859 . South Australia was separately settled and constituted in I 836, Western Australia in I829.

Different The legislatures of the earliest colonies in Australia passed stages of legislatures of Australian i. e. the governor and three or more persons nominated by the colonies. through three stages :-

I. There was first what may be called a nominee council, Crown.

2. Then came what may be called a legislative council, which consisted of twenty-four, thirty-six, or some similar number of members, of which one-third were nominated by the Crown, and two-thirds were elected by the inhabitants for five years.

3. Finally, there was what may be called a parliament (although that term does not commonly occur in the Acts), consisting of the Crown and two houses, namely, a council and a legislative assembly.

Victoria and Queensland did not pass through these three stages as separate colonies, because each, when constituted a colony carved out of New South Wales, received a legislature of the same class as then existed in New South Wales. Thus Victoria received a legislative council and Queensland a parliament.

The details of the Acts relating to the Australian colonies are very instructive as illustrations of the hand to mouth method in which the constitutions of colonies have been made, the variations which were constantly introduced as new cir- 
cumstances arose, the eonstant necessity of resort to Parlia- Arr. VIII. ment, and consequently the utility of the supreme power of Parliament.

The Acts are a tangled mass of legislation, with the result that there is much obscurity in the law, and that many doubts might be raised as to the exact condition of the law. But this obseurity has eaused but little ineonvenience in practice, though it places great difficulties in the way of a writer on constitutional law.

New South Wales will first be treated of separately, as NewSouth the general selieme has been to legislate for New South Wales. Wales, and then to extend the legislation to the other Australian colonies.

Although the official date of the foundation of $\mathrm{New}$ South Wales is 1788 , its beginnings are to be traced at an earlier date.

An Act of $1-84^{1}$ authorized the transportation of convicts to parts beyond the seas which were not designated. Under this Act two Orders in Council of Dee. 6, I786, appointed ' the eastern coast of New South Wales or some one or other' of the islands adjacent,' as the place to which certain offender's named in two lists should be transported.

A subsequent Act of $1787^{2}$ recited that ' it may be found necessary that a Colony and a Civil Government should be established in the place to which such convicts shall be transported . . . and that a Court of Criminal Jurisdiction should also be established within such place as aforesaid with authority to proceed in a more summary way than is used within this Realm according to the known and established laws thereof.'

'The 'civil government' contemplated by the Act consisted of a governor and a lieutenant-governor to be appointed by commission : the court was a court of judicature composed of 'the Judge-Advocate to be appointed in and for such place, together with six officers of His Majesty's Forees by Sea or Land.' Judgements were to be executed by the provost marshal, and the court was to be a court of record.

Such was the constitution under which Australia slowly grew for nearly forty year's. 'The next legislative change came in $1823^{3}$. The Act of that year recited that 'it may be necessary to make Laws and Ordinanees' for New South Wales and its dependencies, but that 'it is not at present expedient to call a Legislative Assembly in the said Colony,' meaning presumably an elected assembly. The course adopted

${ }_{24}$ Geo. III. c. 56 .

${ }^{2} 27$ Geo. III. c. 2.

${ }_{3} 4$ Gico. IV. c. 96. 
APP. VIII. was to authorize the king to constitute and appoint a council - of not more than seven nor less than five persons, upon whose (I) advice the governor was to make laws. By this Act also, Nominee separate supreme courts were constituted for New South council in Wales and Van Diemen's Land, with an appeal from each to
N.S.W. r8a3 to the governor, who on appeals from Van Diemen's Land was 1842 .

(2) The Constitution Act of $1842^{2}$ repealed (s. 53) such parts Legisla- of the Act of I 828 and other Acts as related to the constitution tive Coun- and powers of the nominee council in New South Wales, estabN.S.W. 1842 to 1855 . to be assisted by the Chief Justice of New South Wales.

This constitution lasted only five years. In the meantime Van Diemen's Land had become a separate colony. The Act of $1828^{1}$ again recited that it was not then expedient to appoint a legislative assembly. It substituted, however, in each colony, a council of not more than fifteen nor less than ten persons, and constituted new supreme courts without appeal to the governor. (ss. I to 28 ) various provisions respecting the electoral districts, the elections, the qualifications of members, their tenure of office, the election of speaker, standing orders, and other matters.

The most notable features of the constitution under the Act of $\mathrm{r} 842$ were that the council consisted of thirty-six members, twelve nominated by the Crown, and twenty-four elected by the constituencies: that the council had power to increase its number; so, however, that one-third of the whole council should be nominated by the Crown : and that the franchise was given to freeholders possessing lands of $£_{200}$ value, and householders occupying dwelling-honses of the clear annual value of $\mathfrak{E}_{2} \mathrm{O}$.

'The Act of $\mathrm{x} 85^{\circ}$, entitled 'An Act for the better' government of Her Majesty's Australian colonies,' was passed in consequence of a considerable public feeling which existed at the time in favour of the introduction of representative government into the colonies, and made provision for enabling the Australian colonies to obtain that form of government, a power of which Western Australia did not avail itself until I 890 .

This Act formed the ' District of Port Phillip' into a new colony to be called Victoria, authorized the Legislative Council of New South Wales (after the separation of Victoria) to establish new electoral districts, to alter the number of members chosen by the districts, to increase the number of members

$$
{ }^{1} 9 \text { Geo. IV. e. } 83 . \quad 25 \& 6 \text { Vict. c. } 76 . \quad 3 \text { I3 \& } 14 \text { Vict. c. } 59 .
$$


of the legislative council, and to provide for the elections, APP.VIII. subject to the proviso that if the number of the council was increased, one-third of the whole increase should be appointed by the Crown.

It also (ss. 32 and 33) empowered the legislative council to alter the law in force, under that Act or otherwise, concerning the election of members of the council and their qualification; to establish a parliament ${ }^{1}$ instead of the legislative council, and to confer on it the powers and functions of that comneil, but the Bill for the purpose was to be 'reserved' and laid before Parliament for thilty days before the royal pleasure was signified.

The legislative council of New South Wales, in pursuance of this porrer, passed, in 1853 , a Bill for a constitutional Act, which was reserved, but was held to be beyond the power of the Queen to assent to. Consequently an imperial Act" was (3) passed in 1855 , authorizing (s. I) the Queen to assent to the Parliareserved Bill (which the Qucen subsequently did), and (s. 2) N.S.W. repealing, as from the day of the proclamation of her assent, from $r 855$. such portions of the Acts of 1842,1844 , and $185^{\circ}$, as related to the colony of New South Wales, and were repugnant to the reserved Bill. The Act (s. 3) declared that the provisions of the Acts of 1842 and 1850 , which relate to the giving and withholding of Her Majesty's assent to Bills, and the reservation of Bills for the signification of Her Majesty's pleasure thereon, and the instructions to be conveyed to governors for their guidance in relation to the matters aforesaid, and the disallowance of Bills by Her Majesty, shall apply to Bills to be passed by the parliament ${ }^{3}$, and by any other legislative body which may at any time hereafter be substituted for that parliament. The Act (s. 4) also authorized the legislature of $\mathrm{New}$ South Wales to repeal or alter any of the provisions of the reserved Bill in the same manner as other laws, subject to any conditions imposed by the reserved Bill, and not repealed by the legislature.

The conditions so imposed (ss. 15 and $3^{6}$ of the reserved Bill) were-

(a) That Bills for altering the system of representation in

1 'The term 'parliament' is not used in the Act, which mentions 'a Council and a IIouso of Representatives, or other separato Legislative Houses, to consist respectively of such members to be appointed or olected respectively by such persons and in such manner as hy such Act shall br, determined.'

" $18 \& 19$ Vict. c. 54.

3 'Legislativo Council and $A$ ssembly' are the terms used. 
APr. VIII. the legislative assembly must pass their second and third readings by a two-thirds majority of the legislative assembly, and by a majority of the legislative conncil;

(b) That Bills affecting the constitution of the legislative council must pass both houses by a two-thirds majority, must then be reserved, and laid before Parliament for thirty days.

The requirement of unusual majorities has since been repealed by a New South Wales Act (20 Vict., No. Io), but the requirement of reservation is still, it is believed, in force.

The reserved Bill scheduled to the imperial Act of 1855 , gave (s. I) power to Her Majesty, by and with the advice and consent of the Parliament, to make laws for the peace, welfare, and good government of the colony in all cases whatsoever.

The Acts of 1842 and I 850 had conferred express legislative power on the legislative comncil, giving that council power 'to make laws for the peace, order, and good government of the colony,' and the Act of I 850 further empowered the legislative council, by any Bill establishing a parliament, to confer on that parliament the powers of the council, and thereby to confer on it the full legislative power above quoted.

But the reserved Constitution Bill of New South Wales (scheduled to the imperial Act of $1855^{1}$ ) did not vest in the parliament the powers of the legislative council, but expressly conferred a new legislative power to make laws. The imperial Act of 1855 further repealed such provisions of the Acts of 1842 and 1850 as are repugnant to the reserved Bill, and therefore repealed the statutory authority conferred on the colonial legislative council to make laws.

The Act of 1855 gave power to the Queen to assent to the reserved Bill, but did not expressly enact its validity.

Consequently, the foundation of the legislative power of the Parliament of New South Wales might be open to some doubt $^{2}$, but for s. 5 of the Colonial Laws Validity Act, 1865 , which expressly declares, with retrospective effect, the power of a colonial legislature to make laws respecting its own powers, a power which was exercised by the reserved Bill of 1855 .

Apart from any such requirement in a special Act, the classes of Bills which are required to be reserved are those set out in the Acts of $1 \delta_{42}$ and 1850 , and mentioned below.

The Act of $185^{\circ}$ (s. 33) applied the enactments of 1842 and

1 I8 \& 9 Vict. c. 54.

${ }^{2}$ But see Powell v. Apollo Candle Company, L. R. ro App. Ca. 282, 290. 
I 844 to the Bills reserved under s. 32 of the Act of I 850 , Arp. VIII. and (s. 32) further provided that a eopy of the Bill should be laid before both Houses of the Imperial Parliament for thirty days before Her Majesty's pleasure was signified.

The requirement of s. 32 as to reservation was deelared by 25 \& 26 Vict. e. II, s. 2 to be limited to Bills passed by the legislative council, and therefore would not have extended to Bills passed by the parliament established by that council, had not the foregoing provisions of the Acts of i $8+2$ and i 844 , if not s. 32 of 1850 , been applied by the imperial Act of 1855 (s. 3) to Bills passed by the parliament.

There is, however, some difficulty in so applying them, as they were framed with reference to a legislative council.

Presumably by such application of those provisions to the parliament, the expression 'legislative council' in those provisions (e.g. in ss. 30 and $3 \mathrm{I}$ of the Act of 1842 ) will include both houses of parliament, but this construction is not clear.

The Act of ${ }_{1} 82^{1}$ (s.31) required the reservation of Bills-

(a) altering or affecting the divisions or extent of the several districts and towns which should be represented in the legislative eouncil, or establishing new and other divisions of the same; or

(b) altering the number of the members of the couneil to be chosen by the said districts and towns respectively; or or

(c) inereasing the whole number of the legislative council;

(d) altering the salaries of the governor or superintendent;

$(c)$ altering the salaries of the judges (a requirement repealed by s. 13 of the Aet of $185^{\circ}$ ), or

$(f)$ altering or affecting the duties of customs upon imports or exports (a requirement repealed by an Act of $1866^{3}$, s. 1).

The Act of $1850^{2}$ required (s. 32 ) the reservation of Bills concerning-

(g) the election of the elective members of the legislative couneil, and the qualification of electors and elective members;

(h) the establishment of a parliament;

(i) the vesting in the parliament of the functions of the legislative council.

If and so far as these provisions are applied by the Act of I 85.5, s. 3 , they must, unless repealed by the Act of $I_{5.5}$, s. 2 , as being repugnant to the reserved Bill seheduled to that Aet $^{4}$,

${ }^{1} 5$ \& 6 Vict. c. $76 . \quad$ : I $_{3} \&$ I 4 Vict. c. 59. $\quad{ }^{3} 29 \&$ зo Vict. c. 74.

I So far as thry apply to Victoria and Western Australia, the requirements of $\mathrm{s} .3^{2}$ of the $A$ ct of 1850 have been repealed by the 
APr. VIII. be considered still to apply to Bills passed by the Parliament of New South Wales.

So far as respects Bills concerning $(h)$ and $(i)$, s. 32 of the Act of 1850 may be considered to have been spent, and therefore may be disregarded.

In the result, these Acts would seem to require that Bills dealing with the matters specified in the Act of 1842 , and perhaps Bills dealing with the election of the elective members of the legislative assembly ${ }^{1}$, and the qualification of electors and elective members, should be reserved.

But the power of the New South Wales Parliament to deal with its own constitution depends now upon s. 5 of the Colonial Laws Validity Act of 1865 , and the question arises whether the proviso to that section does or does not extend the reservation provisions of the Act of I 842 to enactments dealing with the constitution. Even if it has that meaning, it can hardly extend the class of Bills to be reserved. Consequently, while Bills dealing with the specific matters above quoted from the Acts of $\mathrm{I} 842$ and 1850 may require to be reserved, Bills in other respects altering the constitution of the parliament are not required by any imperial Act to be reserved, though such reservation may be required by the colonial Act in pursuance of which the constitution is altered.

Section 32 of the Act of 1850 seems not to give power to the parliament to alter its constitution for the reason that the legislative council which established it had no such power; although that council had a power to alter the law respecting the election of the members of the council and the qualification of the electors and members. The power to alter its constitution is given by the Act of 1865 , but the reason referred to above still applies to the question of what Bills are to be reserved by virtue of s. 32 of $185^{\circ}$.

Appro- The Act of 1842 , ss. 34-36, provides that the revenues priation of arising from taxes, duties, rates, and imposts levied on fixed and British subjects in the colony are to be appropriated to the grants for publie service by ordinances of the legislative council, and in governor no other manner; and that an ordinance shall not be passed and judges. appropriating any sum unless the governor has first recommended the council to provide for the specific public service to which the sum is appropriated.

Statute Law Revision Act, I893, the framers of which must apparently have considered that they were repealed by the analogous section of the Act of 1855 , relating to Victoria ; cf. p. 288.

I The Legislative Conncil of New South Wales has no elective members. If it had, the above provision would apply also to the elective members of that assembly. 
Further, the revenue is to be charged with the costs of APr. VIII. collection, and no revenue is to be issued except in pursuance of a warrant under the hand of the governor direeted to the treasurer.

The foregoing enaetments still remain in force unaltered, and have formed an element in contests between the two honses of the parliament ${ }^{1}$.

The Act of 1842 provided that certain sums should be charged on the revenue fund of the colony for the services mentioned in the Schedules A, B, and C to that Act, and (ss. 38,39$)$ limited the power of the legislature to alter those provisions. Schedule A provided for the governor, the judges, the attorney and solicitor-general, and the administration of justice; Schedule B provided for the department of the colonial secretary, treasurer, and auditor-general, and for pensions; Sehedule C provided for publie worship.

The Act of 1850 , ss. I7-19, besides varying the amounts in the schedules in consequence of the separation of the colony of Vietoria, gave power to the colonial legislature to alter the sums and the appropriation thereof, but the Bill for any other alteration was to be reserved.

The financial provisions of the Act of $18_{+2}$, and most of those of the Aets of 1850 , have been repealed by s. 2 of the Act of 185.5 , but apparently the statute law revisers felt some doubt whether the latter portion of s. I 5 of the Act of $185^{\circ}$ was repealed, though that provision seems inconsistent with the existing financial arrangements ${ }^{2}$.

Sections $47-50$ of the Aet of ${ } \$ 42$ provided for the division of the expenses of police, half being paid out of the public revenue of the colony, and half out of loeal rates.

The Act of $\mathrm{I}_{42}$ (s. 29), in giving legislative power to the Crown Legislative Council of New South Wales, provided that no law should interfere with the sale or other appropriation of the lands belonging to the Crown within the colony, or with the revenue thence arising.

A similar restriction was contained in s. It of the $\Lambda$ et of I850, which conferred a similar legislative power upon the legislative couneils of the other Australian colonies.

This provision was virtually repealed as to New South Wales by s. 2 of the Act of 185.5 , which provided that the entire management and control of the waste lands belonging to the Crown in the colony, and also the appropriation of the gross proceeds of the sales of such lands, and of all other proceeds and revenues of the same, including all royalties,

1 See as to Victoria, Parl. 1'., 1873, C. 2 I 73, C. 22 I 7 , p. 35 .

" Section 15 has been repealed hy a Now South Wales Act. 
Arp. VIII. mines, and minerals, should be vested in the legislature, i. e. the parliament of the colony. And a similar course has been taken for the other Anstralian colonies.

Thus the profits from Crown lands, which otherwise would have yielded a revenue to the Government of the United Kingdom, were surrendered to the colony.

The administration of the waste lands, which in law belong to the Crown, and the revenue derived from these lands, has always been a very important matter in the early life of a colony. When the view prevailed that a colony was to be administered for the sole benefit of the mother country, the profits from those lands would clearly be taken by the mother country in aid of its own revenue; but that view has been entirely abandoned as regards the British colonies. It followed that the Crown lands ought to be administered for the benefit of the colony, and the profits of them applied in aid of the public revenue of the colony. The enactment of $x 855$ may be treated as a Parliamentary declaration of this view.

Creation of new colonies out of New Soutli Wales.

The Act of $\mathrm{I}_{42^{1}}$ (by ss. 51 and 52) provided for the creation of a new colony out of the territory then comprised within New South Wales, and lying north of $26^{\circ}$ (altered by the Act of $i 8_{50^{2}}$ to $30^{\circ}$ ) sonth latitude, and for the establishment of a nominee comcil therein.

A consequence of the restriction as to latitude was that when it was desired to establish the colony of Victoria, imperial legislation was required; and the Act of $1850^{2}$ (ss. I and 5) provided for the separation from New South Wales of the district of Port Phillip under the name of the colony of Victoria, fixed the boundaries of the colony, provided for their subsequent alteration, and directed that the colony should have a legislature like that of New South Wales.

The Act of 1850 also (ss. 34, 35) amended the Act of I 842 in relation to the carving of other new colonies out of New South Wales.

South Australia was constituted a British colony in $\mathrm{I} 834^{3}$ by an Act which authorized the Queen to establish a nominee council with legislative power, and to convene a general assembly, elected by the inhabitants, for legislative purposes ${ }^{4}$. This Act, with an amending Act of 1838 , was repealed by the Act of I 842 .

'Tasmania, under the name of Van Dieman's Land, was at first part of New South Wales, but a separate supreme court

$5 \& 6$ Viet. c. 76.

2 I 3 \& 14 Viet. c. 59.

${ }^{3}+\& 5$ IVill. IV, e. 95 , amended by ${ }_{4} \& 2$ Vict. c. 60.

"By $5 \& 6$ Viet. e. 61 . 
was established for it under an Act of I $823^{1}$. In 182.5 it Apr. VIII. was proclaimed independent of New South Wales, and a nominee council was formed under an Act of $1828^{2}$. This Act regulated the civil and judicial establishments for Tasmania as well as for New South Wales.

An Act of $1829^{3}$, after reciting that divers British subjects had effected a settlement of unoceupied lands on the western coast of New Holland, which were known by the name of Western Australia, and that it was necessary to make temporary provision for the civil government of the settlement, authorized the Queen in Council to establish a nominee cotmeil.

The Aet of 1850 established (ss. 2, 3) in Victoria, and authorized (ss. 7,10 ) the existing nominee couneils of Tasmania, South Australia, and Western Australia to establish legislative councils, and provided for the creation of the first electoral districts, and for the election of the elective members of the legislative councils. It also (s. II) authorized the legislative council, when established, to create new electoral districts, to alter the number of nembers to be chosen by each distriet, to inerease the whole number of members of the council, to regulate the elections, subject to the proviso that if the number of councillors was increased, one-third of the increased number should be nominated by the Crown.

The Act of $185^{\circ}$ (s. I2) applied to each of these four colonies-

(a) The provisions of that Act (s. 4) respecting the qualification and disqualification of electors in New South Wales; and

(b) The provisions of the Act of 1842 (i.e. ss. 5 to 9,12 to I 4,15 to 19 , and 22 to 29 ), respecting the elective members of the legislative council, their qualifieation, appointment, tenure of office, and resignation, the dissolution of the council and election of the speaker, the quorum, the oath to be taken, the standing orders, and the issue of writs; and

(c) The provisions of the Aet of 1842 (i.e. ss. 30 to 3.3 and 40) respecting the proposal of drafts of laws and amendments to the couneil, the griving and withholding of the Queen's assent to Bills, the reservation of Bills for the signification of the Queen's pleasure thereon, and the Bills so reserved, the instructions to the governor for his guidanec in relation to the matters aforesaid, and the disallowance of Bills by the Qneen.

The Act of I 850 (ss. 32 and 33) also made for each colony

${ }_{4}{ }_{4}$ Geo. IV. c. 96.

${ }^{2} 9$ Geo. IV. c. 83 .

3 1o Geo. IV. c. 22. 
Apr. VIII. the same provision as those sections made for New South Wales respecting the establishment of a parliament and electoral matters ${ }^{1}$.

The Act of 1850 (s. 14) also authorized the governor of each colony, with the advice of the legislative council, to make laws for the peace, welfare, and good government of the colony; and to appropriate the revenue subject to the proviso that such laws should not-

(a) Be repugnant to the law of England; or

(b) Interfere with the sale or appropriation of the Crown lands in the colony or the revenue thereof; and

(c) If appropriating money for the public service, should be passed only on the recommendation of the Crown; and that no part of the revenue should be issued except in pursuance of a warrant under the hand of the governor directed to the treasurer ${ }^{2}$.

The Act (s. I5) provided for charging the revenues of the colonies with the management thereof, and for the audit of those revenues; while s. I 6 as respects Victoria, and ss. 16 to I9 as respects Victoria, Van Dieman's Land, and South Australia, made provision with respect to the appropriation of sums granted, and the grants for civil and judicial services, similar to those mentioned above as made for New South Wales.

Section 20 provided for the ereation of district councils in Victoria, while ss. 2I and 22 extended to Tasmania, South Australia, and Western Australia, upon the establishment of a legislative council, the provisions of the Act of 1842 respecting the creation of councils in the different distriets, and (s. 24) amended those provisions.

Section 27 gave the same power to the legislatures of each colony to impose duties of customs, as was given to New South Wales.

Section 28 provided for the judicature in the colony of Victoria, and s. 29 authorized the colonies of Tasmania and Victoria, but not the two other colonies, to make provision for the administration of justice.

The Act of 1850 thus placed each of the four colonies in substantially the same position. Their subsequent history varies.

Vietoria. In Victoria the legislative eouncil passed a Bill for a constitution in 1853 by virtue of the powers conferred by the Act of 1850 (s. 32 ).

The Bill was reserved, and, as the Queen had not porver to

See above, p. $28 \mathrm{r} . \quad{ }^{2}$ As to this in Victoria see above, p. 283 , note I. 
assent to it, an imperial Act anthorizing her assent to it Arp. VIII. was passed in $18.55^{1}$, in almost the same terms as that passed for New South Wales.

The Act of 185.5 , by s. 2 , repealed such parts of the abovementioned Acts of $18+2$ and 1850 as related to the colony of Victoria and were repugnant to the reserved Bill, and gave to the colony the management and control of the Crown lands.

It further (s. 3) enacted that the provisions of the Acts of 1850 and 1842 , which relate to the giving and withholding of Her Majesty's assent to Bills, and the reservation of Bills for Her Majesty's pleasure, and the instructions to the governors for their guidance in relation to Bills, and the disallowance of Bills, shall apply to Bills passed by the legislature constituted under the reserved Bill, or by any other legislature substituted therefor.

By s. 4 the legislature was authorized to repeal or alter the provisions of the reserved Bill, subject to the conditions thereby imposed.

The reserved Bill was assented to by the Queen and became the Constitution Act. It (by s. I) authorized the Queen, by and with the advice and consent of the council and assembly, to make laws in and for Victoria in all cases whatsoever.

The Bill (by s. 6o) provided that the legislature should have full power to alter any part of the Bill, subjeet to the proviso-

(a) That the Bill by which an alteration of the constitution of either house of the legislature should be made ${ }^{2}$ must be passed with the concurrence of an absolute majority of each house, and

(b) That the Bill should be reserved.

But (s. 6I) provided that the legislature should be free, without the above restrictions, to alter the qualifications of clectors and of members of either house of the legislature, and to establish new electoral provinces or districts, and to alter or inerease the number of members either for any province or district or the whole number of the house, and to alter the methods of election.

The result appears to be that the legislative power of the Legislature of Victoria depends now on the Constitution Act of 185.3 and the Colonial Laws Validity Act of 1805 , and that apart from the limitations of special Acts, whether imperial or colonial, the only general restriction on that power is

1 I \& 19 Vict. c. 55.

2 Or which varied the Civil List as scheduled to the Constitution Aet. 
Apr. VIII. contained in the provisions of the Act of $1842^{1}$, respecting the reservation of certain Bills for the signification of the Queen's pleasure.

For this reason, most of the provisions of the Acts of 1842 and $1850^{2}$ which gave legislative power to, or impose restrictions on, the legislative council of Victoria, have been repealed as regards Victoria by the Statute Law Revision Act, $1893^{3}$.

South The legislative council established in South Australia Australia. under the Act of $8_{5} 0^{2}$ passed two Acts in pursuance of s. 32 , the powers of which became thereby exhausted. One of these Acts (No. 2 of $1855^{-6}$ ), establishing a parliament, was reserved and laid before the imperial Parliament and assented to by Order in Council in accordance with s. 33 of the Act of $1842^{1}$. The second (No. 10 of $\times 855^{-6}$ ), which created the electoral districts, fixed the number to be returned for each district, and provided for the elections, was nct reserved.

Act No. Io was, however, held to be within the terms of s. $3^{2}$ of the Act of 1850 , and therefore, not having been reserved, to be invalid. In consequence an imperial Act was passed in $1863^{4}$ confirming the above-mentioned colonial Acts.

Section 34 of the Colonial Act No. 2 of $1855^{-6}$ provided that any Bill passed by the South Australian Parliament for altering the constitution of the legislative council or house of assembly must be passed by absolute majorities in both houses, and should be reserved.

In I86 I the South Australian Parliament passed an electoral Act ${ }^{5}$ which altered the boundaries of electoral districts, and the number of members returnable by them. This was considered to be invalid, because it had not been passed by the absolute majorities which were required by the Constitution Act of $1855-6$, and also because the legislature had no power to pass the Act. The governor and legislative council were authorized to give to the parliament established under the Act of I850 such powers and such only as were already possessed by the legislative council. Therefore as that council had no power to alter its constitution, the parliament had also no such power. This objection was removed by the Confirmation Act, $26 \& 27$ Vict. c. 84 .

Whatever power the Constitution Act of $1855^{-6}$ gives to the South Australian Parliament, the confirmation of that Act by the imperial Act of $1863^{4}$ is not a confirmation of

\footnotetext{
${ }^{1} 5 \& 6$ Vict. c. $76 . \quad{ }^{2}$ I3 $_{3}$ I 4 Vict. c. $59 . \quad{ }^{3}{ }_{56}^{6}$ \& 57 Vict. c. 54. 4 26 \& 27 Vict. c. 84 .

${ }^{5}$ No. 20 of $186 \mathrm{r}$.
} 
the same character as in the ease of Vietoria or New South APr. VIII. Wales.

The Act of 1863 referred in the preamble to the doubts as to the validity of the South Australian Acts, and enacted in general terms that all laws theretofore passed by any colonial legislature with the object of declaring or altering the constitution of the legislature or of any braneh thereof, or the mode of appointing or electing the members of the same, shall be deemed to have had effect, as if the legislature had possessed full powers of enacting laws for the objeet aforesaid, and all formalities prescribed in respect of the passing of such laws had been duly observed.

This confirmation seems limited by the terms or objects of the laws eonfirmed. But the Colonial Laws Validity Aet of $1865^{1}$, by s. 7 , deelared all Sonth Australian Acts previously passed to have been valid.

The result is that some of the powers of the South Australian Legislature may still depend upon the imperial Aets before the Colonial Laws Validity Aet", as, for instanee-

(a) The power of altering electoral distriets and the number of members (s. I I of 1850 );

(l) The general legislative power of the Legislature of South Australia (ss. I4 and 15 of the Act of $185^{\circ}$ );

(c) The power to impose eustoms duties (s. 27).

Regard being had to the condition of the law, it is not surprising that mistakes have been made. Resort has been had to the imperial Parliament, on several oceasions, to confirm eolonial Acts held invalid because either not reserved or otherwise not complying with the law ${ }^{3}$.

In Tasmania (the name given to Van Diemen's Land in Tasmania. I 85.3), the legislative comncil, appointed under the Act of $185^{\circ}$ (s. 7), in pursuance of s. 32 , passed in 1855 the Constitution Act of that year (1 8 Vict., No. I7), which has since been supplemented by 48 Vict., No. 54, and 49 Viet., No. 8.

That Act established a parliament, both houses of which are elective, and regulated the electoral districts and the mode of election.

The Constitution Act of 1855 was not speeially confirmed by an imperial statute, as in the ease of New South Wales

128 \& 29 Vict. c. 63. Seo $\Lambda_{\text {pp. }}$ V.

"It might be argued that the oath to bo taken by members of the two houses of the South Australian Legislature depends upon ss. 25 and 26 of the $\Lambda$ ct of $18_{42}$, and that the valility of South Australian Aets may ine affected by the nom-obscrvance of those sections.

${ }^{3}$ In $1862,25 \& 26$ Vict. c. 11 ; in $1863,26 \& 27$ Vict. c. 84 ; in 1865 , $28 \& 29$ Vict. $\therefore 63$; in $1894,56 \& 57$ Vict. c. 72. 
APr. VIII and Victoria, and consequently the remarks applying to South Australia apply also to Tasmania.

The difficulties with respect to the validity of South Australian Acts do not appear to have been actually raised in the case of Tasmania; but the confirming Act of $186.3^{1}$ was passed in general terms, and therefore would apply to Tasmanian as well as to South Australian Acts. The Act of I 86.5, s. 7, did not however apply to Tasmanian Acts.

Western In Western Australia the legislative council was estabAustralia. lished under the Act of 1850 (s. 7), on the petition of not less than a third of the householders. But this council did not exercise the powers conferred by $s .32$ of the Act of $185^{\circ}$ until the year 1889 , when they passed a Bill for a Constitution Act, which was reserved and was not to come into operation until such portions of the Acts of 1842,1844 , and $185^{\circ}$, as were repugnant to it, had been repealed.

The Queen was authorized to assent to the Bill by an imperial Act of $1890^{2}$, by which (s. 22) such portions of the above-mentioned imperial Acts of 1842,1844 , and 1850 , as are repugnant to the scheduled Bill, are repealed.

But the same section applied the provisions of the Acts of I 842 and I 850 as to the Royal Assent to a disallowance of Bills and their reservation in terms similar to those used in the case of Victoria in 1855 .

The Act (s. 5) authorized the Legislature of Western Australia to alter or repeal any of the provisions in the scheduled Bill in the same manner as any other laws of the colony, subject to the conditions imposed thereby.

The Queen assented to the scheduled Bill, which thus became the Constitution Act. Under it (s. 73) the parliament of the colony has full power to repeal or alter any of its provisions, subject to the proviso that any change in the constitution of the legislative council or assembly should not be effected unless the Bill was passed with the concurrence of an absolute majority of the members of each house; and also that any Bill for the election of a legislative council, which either is passed before the expiration of six years from the first summoning of it, or interferes with the operation of ss. 69 to 72 , and the schedules (i.e. the civil list charges, and certain pensions to ex-officials) should be reserved.

It also (s. 2) gave full power to the legislature to make

$226 \& 27$ Vict. c. 84.

${ }^{2} 53 \& 54$ Vict. c. 26 . This Act followed closely the imperial Acts of 1855, authorizing the Queen to assent to the Constitution Acts of Victoria and New South Wales. 
laws for the peace, order, and good government of Western Arr. VIII. Australia, and gave it all the powers and functions of the then subsisting legislative council.

The effect of the imperial Act of 1890 , followed by the Statute Law Revision Act, $1893{ }^{1}$, is that the enactments of the Act of 1850 conferring powers on the Legislature of Western Australia are repealed, and the powers of the legislature of that colony depend (except for the Colonial Laws Validity Aet, $186_{5}^{5}$ ), entirely upon the Constitution Act of I 800 .

The position, therefore, of Western Australia is precisely similar to that of New South Wales above mentioned.

Queensland differs from the other Australian colonies in Queensthat it was not made a colony until after 1850 , and is not land. mentioned by name in the Acts of $18+2,1844$, or 1850 , nor indeed in any Act except the Act of $186 \mathrm{I}^{2}$ (which confirms the Letters Patent establishing it), and never had a nominee or legislative eouncil.

The Acts of 1842 (s. 51 ) and $185^{\circ}$ (s. 34) gave the Queen in Council power (as above mentioned" under New South Wales) to erect into a separate colony any territories forming part of New South Wales and lying north of the thirtieth degree or south latitude.

The Constitution Act of New South Wales ${ }^{4}$ (s. 46) provided that nothing in that Bill should prevent the Queen from altering the boundary of the colony on the north in sueh manner as to Her Majesty might seem fit; and $s$. 7 of the Imperial Act of $1855^{5}$ provided that the Queen by Letters Patent might erect into a separate colony any territory separated from New South Wales by such alteration of the northern boundary.

The Act of 1842 (s. 52) authorized the Queen, in ereating the colony, to establish a nominee couneil.

The Act of $1850(\mathrm{~s} .35)$ provided that the legislature which might be constituted in any such new eolony under the Aet of $18+2$, should have power to establish a legislative council, and in effeet should liave the same power, and be subject to the same enactments of the Act of 1850 , as the colony of Western Australia.

The Act of 185,5 directed that the Queen, in establishing the colony, should by Letters Patent or Order in Council provide for the government of the colony, and for the

${ }^{1} 5^{6} \& 57$ Vict. e. $54 . \quad 2{ }_{24} \& 25$ Vict. c. 44 . 2 sce p. 284.

- The reserved Bill scheduled to 18 \& 19 Vict. c. 54 , and assented to Ly the Queen under the power conferren by that $\Lambda$ et.

s 18 \& 9 Vict. c. 54 . 
Arp. VIII. establishment of a legislature therein, in manner as nearly resembling the form of government and legislature which should be at such time established in New South Wales as the circumstances of such colony would allow, and full power was to be given by the Letters Patent or Order in Council to the legislature of the colony to make further provision in that behalf.

Thus the power given by each Act of creating a new colony was accompanied by a power to create in that colony a legislature of such character as at the date of the Act was existing in New South Wales.

Moreover, the New South Wales Constitution Act of 1855 was altogether repealed as to Queensland by an Act of the Queensland Legislature (32 Vict., No. 39).

In 1859 , Letters Patent of June 6 were made, creating certain parts of the colony of New Sonth Wales into the colony of Queensland, and an Order in Council, dated June 6, 1859, was made for the government of the colony and the establishment of a legislature ${ }^{1}$.

But the form of govermment and legislature so established did not in all respects resemble the form of government and legislature at that time established in New South Wales, and consequently doubts arose as to the validity of the order. These doubts were removed in $186 \mathrm{I}$ by an imperial Act ${ }^{2}$, which (s. 4) repealed the provisions of s. 7 of the Act of 1855 , requiring the form of government and legislature to be the same as that established in New South Wales.

If a legislative council had been established in Queensland under s. 35 of the Act of 1850 , ss. 12 and 32 of that Act would have applied, and consequently all Acts subsequently passed by the legislature of Queensland would have been subject, as respects the reserved Bills, to the provisions respecting those Bills of the Act of 1842 , i.e. ss. 30-33 and 40.

As no legislative council was ever established under s. 35 of the Act of 1850 , any application of the provisions of the Act of 1842 , in respect of reserved Bills, to the lesrislature of Queensland must depend upon the Letters Patent and Order in Coumcil and not on any statute.

But it may be questioned whether the repeal by the Act of $186 \mathrm{I}$ of that part of $\mathrm{s}$. 7 of the Act of 1855 , which required the legislature in any new colony to be similar to that of New South Wales, did not exclude the legislature from the provisions as to reserved Bills of the Act of 1842 .

1 See Stat. R. \& O. Rev., vol. vi. pp. 54, 55.

${ }^{2} 24$ \& 25 Vict. c. 44, s. 3. 


\section{INDEX}

Absolute gorernment, 7, 93 .

Aden protectorate, 169 .

Administrator, in Southern Rhodesia, I9I.

Admiralty, 17.

Admiralty jurisdietion, $3 \hat{3}, 124-5$, 129.

African Orders in Council for protectorates, $185-95$.

Agriculture, in British North America Act, 202.

Alderney, subordinate to Guernsey, 38 .

Aliens, naturalization of, 70, 200.

Amatongaland Order in Council, I 88 .

American colonies, 7.

Amnesty, 111.

Annexation of territory, 4 .

Annual meetings of legislature, 68.

Antigua, 97, 197.

Appeal, to Privy Council, 32-4.

Appropriation of taxes, 282, 286.

Army. Sce Military forces.

Arrest on mesne process, I 24.

Assent to Bills, 77, I13-21.

Australian Commonwealth, money Bills, 6o; constitutional position of executive, 64 ; power of constitutional change, 76 ; history of federation, $84-6$; analysis of imperial Act, 86-9; compared with Dominion of Canada, 89 ; constitution and legislature, App. i.

Bahamas, 197.

Balfour, Arthur, estimate of Sir H. Jenkyns's publie serrices, $\mathrm{xx}$. Bankruptey, 1 2, 27, 160; in British North America Act, 200, 208.

Barbadoes, 197.

Barbary States, 252.

Basutoland, I69, I 98, 234.

Bechuanaland protectorate, I $87-$ 8, 234.

Behring Sea, 25-6, 147 .

Berlin, conference of, $175-7$.

Bermuda, 197 .

Bigamy, 12, 27, 137 .

Jishop of Man, 39 .

Bismarck, Prinee, 168.

Board of Control, 42.

Hombay, government of, 46 .
Borneo, British protectorates in, 169-71, 195 .

Boundaries of British dominions, alteration of, $2-4$.

British Bechuanaland, 169, 234.

British Central Africa, 169.

British Columbia, 77, 81, I19, App.i.

British Guiana, 197.

British Honduras. See Honduras.

British India, definition, 44.

British Islands, definition, 37 .

British New Guinea, 197.

British North America Act, partly reprinted, I99-202; judicial construction, 203-12.

British North Borneo Company, I 69-7I, I 73, I 84 .

British possession, definition, 2.

British protected persons, in foreign states, I 55 .

British ship, jurisdiction for offences committed on, I 30 .

British South Africa Company, I69, 184 .

British subject, on foreign slip', I 40.

British subjects, under Foreign Jurisdiction Act, I54; under Capitulations, 245 .

Brunei, British protectorate of, I69-7I.

Bryce, James, testimony to Sir H. Jenkyns's official services, xxi.

Burgher force, in Cape Colony, 20. By-laws, I6.

Canada, 8-9, 17, 30; militia, 19; money Bills, 6o; position of ministers, 62; senate, 66; house of commons, 67 ; power of constitutional change, 75 ; history of federation, 8I-4; compared with Commonwealth of Australia, 89; assent to rills, I 4 ; disallowanee of Bills, I47; constitution and legislature, App.i.

Cantonments, jurisdiction over, 196.

Cape Colony, 9; burgher force, 20 ; money Bills, 61; constitutional position of exceutive, 63 ; position of natives, 94 ; exten- 
sion of criminal law to neighbouring territory, 143 ; constitution and legislature, App.i.

Capitulations, the, their history, 148-5I.

Captain-general, 100.

Carnarvon, Lord, i I I.

Ceded or conquered colonies, 6 .

Ceylon, I7, 29, 197.

Chinnel Islands, relations to the Home Government, 14, 37-9.

Chartered companies, I72-3, I 84 , 195.

Chief commissioner, of province in India, 47.

China, special provision for criminal jurisdiction, $144,163.252$.

Chinese immigration, 24, i 18.

Circulars, to governors of colonies, IOO.

Civil service, in India, 52-3.

Coasting trade, 28.

Codes, in India, 51 .

Coinage, regulation of, 29; in British North America Act, 199.

Coleridge, Justice, 128.

Collision, jurisdiction in, 125 .

Colonial Laws Validity Act, reprinted, 239-4I.

Colonial regulations, 100.

Colony, definition, 2 ; alteration of boundaries, 2-4; settled colonies, 5-6; conquered or ceded colonies, 6 ; instruments of constitution, 7 ; modes of governing, 7 ; self-governing colonies, 8-9, 54-90.

Coloured population in colonies, $9,67,94,96$.

Commander-in-chief, in India, $5 \mathrm{I}$; in Canada, 81, IOI; in Australia, 87 .

Commissioner, in British protectorates, I72-3.

Commissions, of governors of colonies, 99; of GovernorGeneral of Canada, 213-9; of Governor of New South Wales, 2I9-3I; of Governor-General of India, 232-3; of High Commissioner of South Africa, 2336; of High Commissioner of Western Pacific, 236; of High Commissioner of protected Malay states, 237-8.

Commonwealth of Australia, money Bills, 60 ; constitutional position of executive, 63-4; power of constitutional change,
76 ; history of feleration, $84-$ 6; analysis of imperial Act, 86-9; compared with Dominion of Canada, 89-90; constitution and legislature, App. i.

Companies, British, not exempted from colonial law, 30 .

Congo Free States, consular jurisdiction in, $152,158$.

Conquered or ceded colonies, 6,95.

Constantinople, I6o.

Constituent assemblies, 72 .

Constitutional change, in colonies, 72; in Australia, 73; in New Zealand, 74; in Canada, 75; in Australian Common. wealth, 76; in colonies with representative legislatures, 240.

Consular jurisdiction, consuls in civilized states, I 48 ; the capitulations, I 49-51; the Foreign Jurisdiction Acts, $15 \mathrm{I}$; power of deportation, I52; nature of the jurisdiction under these Acts, I 53-4; persons subject to this jurisdiction, and law applicable, $154^{-7}$; in what countries capitulations exist, I 57 ; in the Congo Free States, I 58 ; the Ottoman Dominions Order, I59-6I ; imprisonment and deportation, I6I; Persia and Persian Gulf, I62; Morocco, I62; Siam, 163; China and Corea, I63; Japan, I63-4.

Consul-general, in British pro. tectorates, I72-3.

Convicts, 277 .

Cook Islands, I69.

Copyright, 26-7, I I 7-18, 200.

Corea, British jurisdiction in, 163 . Council, of Governor-General of India, 42, 45; of Secretary of State for India, 43; of Governors of Bombay and Madras, $46-7$.

Covenanted civil service, 52 .

Crime, local jurisdiction for, 125-47.

Crown, the, as link with colonies, I2; sovereignty of, in India, 43, legislative power in not selfgoverning colonies, 95 ; as fountain of honour, Ioo; legislative power in foreign coun. try, 153; legislative power in protectorates, I93, 195.

Crown, or not self-governing, colonies, two classes, 91 ; re- 
lation to Home Government, 9I; the legislature, 92 ; the executive, 92-3; relation of representative body to local government. 94; conflict between Jegislature and executive in Malta, 94; legislative power of Crown, 95; forms of constitutions, 96-7; federation in West Indies, 97- 8 .

Crown lands, in colonies, $2 \delta_{3}$.

Customs duties, 27, 87, 106.

Cyprus, capitulations supersederl, I 57.

Deadlock, 66, 122.

Deceased wife's sister, marriage with, 28 , I I $7-8$.

Deensters, 39-40.

Dependency, anbiguous, I; India, 41.

Deportation, in New Zealand, 70 ; under Foreign Jurisdiction Acts, 152, 161, 265.

Dicey, Prof., quoted, 3I, 54-5, 62, 72 .

Dignities and honours, in colonies, IoO.

Disallowance of Bills, I 5-6, 779, II 3-2I.

Dismissal of ministers, I IO.

Dissolution, power of, I I I-3.

Distribution, statute of, 72 .

Dirorce, 226, 230.

Dollars, 29-30.

Dominica, 97, 197.

Dominion of Canada, militia, I9; money Bills, 6o; position of ministers, 62; senate, 66; house of commons, 67 ; power of constitutional change, 75 ; history of federation, $8 \mathrm{I}-4$; compared with Commonwealth of Australia, 89-90; assent to Bills, I 4-5; disallowance of Bills, I 7 ; constitution and legislature, App. i.

Durham, Lord, report on Canada, 57.

East Africa Protectorate, 29, I69; Orders in Council, 189.

Fast India Company, brief history, 4I-3.

Education, in British North Anerica Act, 20 I.

Egypt, international courts il, 157.

Empire, British, 23.
Empire, of Indial, 44.

English law, in settled colony, 5-6, 3I; in British India, 51 .

European British subject, jurisdiction over, in India, 50.

Executive, the, statutory definitions of position of, $61-5$; in self-gorerning colonies, 65,76 ; in a crown colony, 92-3.

Exequatur; consnlar, I 48 .

Explosives Act, offences against, 136.

External affairs of colonies, 26-3I.

Extradition, I2, 26, I 37.

Extra-territorial jurisdiction, sovereignty limited to territory, 123; civil jurisdiction of English courts, 123-5; criminal jurisliction local, 125 -7 trial of persons at locality of crime, 127-8; crimes committed in military lines abroad or at sca, I28-30; offences committed at sea, I30; prisoners on board a foreign ship, I3I-5; illustrative cases, 135-6; offences committed on land out of British dominions, 136 ; foreign doctrines, I37-40; no power to try British subject for offence on board a foreign ship, I40I ; offences on land in nonChristian or barbarous country, I 42 ; trial of offences by British subjects in Newfoundland, 142 ; in Honduras, New Zealand, Otaheite, and Pacific, 143 ; in South Africa, I43; in Sierra Leone, I44; in China, I 44; in the Pacific, 145-7; jurisdiction to prevent sinuggling and to protect fisheries, 147.

Extra-territorial legislation, forbidden to colonies, 69-71.

Extra-territorial powers, of $\mathrm{Go}_{0}$ vernor-General of India, 46.

Eyre, governor of Jamaica, IO4.

Factories, in India, 41-2; in the Levant, I 49.

Falkland Islands, 2, 5, I 97.

Federal Council of Australia, 84-5.

Federations, within the empire, 23, So; Dominion of Canada, SI-4; Commonwealth of Australia, 84-9; the two contrasted, $89-90$; in the West. Indies, 97-8.

Fenale franchise, 67 . 
Fiji, I 46, I 97.

Fisheries, extra-teritorial jurisdiction for protection of, 147.

Flag, British, 25, I 30.

Foreign Deserters Act, I 35 .

Foreign Enlistment Act, 26.

Foreign Jurisdiction Act, 1 51-3; reprinted, 266-75.

Foreign ship, jurisdiction for offences on, I 24-5, I 31, I 35-6, I 40-I.

Foreigners, crimes by, on foreign ships within Britisl waters, 26 ; in British protectorates, $174-7$.

Forsyth, quoted, I32.

Fortifications, in colonies, $2 \mathrm{I}-2$.

Franchise, in colonies, 67, 82 .

Frenchshore, of Newfoundland, 24 .

Frontier disputes, 26.

Gambia, 197.

GermanEast Africa Company, 177. Gibraltar, I 5, 95, I98.

Gold Coast, I97.

Governor of colony, his appointment and powers, I4, 34-5; appointment and commission, 99 ; dignities and honours, I0O; military command, IOO-2 ; statutory powers, IO2; not a viceroy, IO2 ; power given by commission, 103; reserve power, I05; of self-governing as opposed to other colonies, I05; acts as imperial and local officer, I05-6; social influence, I07; relations to ministers, 107-IO; power of pardon, I 10I ; power of dissolution, I I I3 ; assent to legislation, II36 ; disallowance by Crown, I 16 8; disallowance in Canada, I $8-2 \mathrm{I}$; Acts ultra vires not necessarily disallowed, $12 \mathrm{I}$; in a colony not self-governing, I 22 ; trial for oppression, 138 ; commissions and instructions, 21 3-38.

Governor-General, of Australia, 87 ; of Canada, 8 I, 84, I00, I Io, I I9; of India, 42-8.

Graliam-Harrison, $\mathrm{Mr}$., assisted in revision of book, xxii.

Grenada, 98, 197.

Grey, Earl, 58-9, 8o, 84 .

Guernsey, constitution of, $3 \delta$.

Halifax, $2 \mathbf{I}$.

Hall, Mr., quoted, 134, 147, 150 ,
I 54, I 56, I 58, 166, 168, 177-8. 179-80.

Halleck, quoted, I 3I, 166.

Hamilton, Sir E., testimony to Sir H. Jenkyns's official services, $\mathrm{xx}$.

Hanse ports, 247.

Hanseatic merchants, 149.

Heligoland, 3 .

Hertslet, 170, 183-4, 194, 252-3.

High Commissioner, of South Africa, 233-6; of Western Pacific, 145, 236 ; of Protected Malay States, 237.

High Court, in England, colonial governors amenable to, 35 ; of Australia, 87.

High Courts, in India, 50.

High seas, definition of, I 29.

Holland, Prof., referred to, I 37.

Home Government, relations with colonies, 10-36; the imperial Parliament, ro-I2; the Crown, 12 ; acts of Home Government, 13 ; the governor, 14 ; the local legislature, 14-6; naval and military, 17-22; subjects for imperial authority, 22 ; international relations, 22-6 ; intercolonial relations, 26 ; external affairs, 26-3I ; judicial arrangements, 3I-4; the governor, 34-6; internal government, 36 .

Honduras, constitution, 96, 197 ; imperial Act for trial of murders, I43, 252, 257.

Hong-Kong, I44, I 97.

'Honourable, applied to colouial ministers, 65 .

Honours and dignities, in colonies, 100.

House of Assembly, 7, 67.

House of Commons, in Canada, 67 . House of Representatives, 67.

Immigration, in British North America Act, 202.

Imperial federation, 23.

India, surrender of territory, 3 ; Secretary of State, I4; marine service, 17 ; coinage, 29 ; a dependency, not a colony, 4I ; outline of history, 4I; Home Gorernment, 42-3; local government, 44 ; governor-general, 44-5; central legislature, 45; provincial governments, 46-8; comparison with colonial go- 
rernments, 48 ; control by Home (iovernment, 49 ; courts of justice, 49-5 I system of law, $5 \mathrm{I}$; nililitary forces, $5 \mathrm{I}$; civil service, $5 \mathrm{I}-3$; trial of officials for misdemeanours, I 39: subjects of native states under Foreign Jurisdiction Aets, 155, 272 ; natives of, under Ottoman Dominions Orler, I60-2 ; protectorates, I96.

Indian Land Acquisition Act, I $88-9$.

Indians, American, I67, 200.

Influence, sphere of, I.

Initiative in legislation, 92.

Instructions, to governor of colony, 99; to governor of New South Wales, 228-3I.

Intercolonial relations, of colonies, 26.

International copyright, 26.

International courts, in Egypt, 157.

International relations, of colonies, 22-6.

Ionian Islands, I67, 246-7. -

Jamaica, representatice legislature, 92, 96, 197-8.

Japan, consular jurisdiction abolished, I63.

Japanese immigration, 24, II9.

Jefferies, Chief Justice, 259.

Jenkyns, Sir Henry, brief biography, i-xv; Lord Thring's estimate, xvi-xviii ; John Morley's estimate, $\mathbf{x v i i i - x x . ~}$

Jersey, constitution of, 38 .

Judge-Advocate, 277 .

Judges, 3 I.

Judicial arrangements, in colonies, $3 I-4$.

Jury, in consular eourts, I60-I.

Kermadec Islands, I69.

Keys, House of, 39.

King's council, in Canada, 100.

Labuan, I98.

Lagos, 197.

Leeward Islands, federation of, $97,197$.

Legislative Assembly, 67 .

Legislative Council, 66, 276.

Legislature, the, in liritish possessions, 14-6; in Chamnel Islands, 38 ; in Isle of Man, 39 ; in British India, 45-8; in self-governing colonies, 66-79; in a crown colony, 92.95; in colonies generally, A pp. i, 197-S.

Letters Patent, creating office of governor of eolony. 99, 2I3-6.

Levant Company, the, I49-5I, 248-50.

Lewis, Sir G. C., referred to, 1-2, 9-10, 24, I27, 149.

Lieutenant-governors, of Indian provinces, 47 ; of Canadian provinces, 83, 90, II 9.

Lighthouses, in British possessions, II ; in Canada, I99.

Lower Canada, $\delta$ I.

Lower house, in colonial legislatures, 67 .

Madagascar, I 58 .

Madras, goverument of, 46 .

Mahommedan country, offences by British subjects in, I $\$ 2$.

Maine, Sir H.S., quoted, I65-6, I 78 .

Malay protected states, 169 ; commission of High Commissioner, 237.

Maldive Islands, I69.

Malta, Protestant marriages, 33 ; conflict between legislature and executive, 94-6; representative assembly, 197 .

Man, Isle of, relations to the Home Government, I4, 39-4I.

Manitoba, 77, 81, App. i.

Maoris in New Zealand, 67.

Marriage, with deceased wite's sister, I I 7-8; by consuls, 148 ; in a Russian factory, 149.

Matabeleland Order in Council, I 90, 234.

Mauritius, 197 .

Merchandise marks, 30 .

Merchant shipping, 28 .

Merivale, Herman, quoted, I05.

Military command, in India, 51 ; in colonies, 100-2.

Military forces, in colonies, I 7-22; in India, 42, $5 \mathrm{I}$.

Military offences, I 28-9.

Ministers, position of, in colonies, $6 \mathrm{I}-6$.

Mints, in colonies, 29.

Misclemeanours, trial of colonial officials for, 139 .

Money Bills, in colonial legislatures, 32, 60-I.

Montserrat, 97, 197.

Morley, Joln, estimate of Sir H. Ienkyns's publie services, xviii$\mathrm{xx}$. 
Morocco, consular jurisdiction in, $162,252$.

Nowatt, Sir Francis, testimony to Sir H.Jenkyns's official services, $\mathrm{xx}$.

Murder, outside territorial jurisdiction, I36, 138 .

Muscat, 173 .

Mutiny Act, in India, 42.

Natal, 9, 26, 63, 74, 94, I44, 189, App. i, 234.

Natives, in Indian civil service, 53 .

Naval forces, in colonies, I7; in India, 42.

Negri Sembilan, 237.

Negroes, in West Indies, 96.

Neutrality, 26.

Nevis, 97, 197.

New Brunswick, 8, 77, 8I-4, App.i.

Newcastle, Duke of, 107.

Newfoundland, 9, 24, 58, 74, 81, 142, App. i.

New Guinea, I69, I97.

New South Wales, military force, 19 ; money Bills, 6o; constitutional position of executive, 62 ; power of constitutional change, 73; constitution and legislature, App. i ; patent for governor, 2I9-23; commission of governor, 223 ; old instructions to governor, 224-8; present instructions, 228-3I; foundation of, 276; early constitutional history, 277; nominee council, 278; legislative council, 278; parliament, 279-82 ; appropriation of taxes and fixed grants for governor and judges, 282; crown lands, 283 ; creation of new colonies, 284-6.

New Zealand, military force, 2o; money Bills, 60 ; constitutional position of executive, 62 ; power of constitutional change, 74-5; Government Securities Act, 80; imperial Act for trial of murders in, I43; constitution and legislature, App. i.

Niger Territories, I69, I 7 I.

Nominee councils, in Australian colonies, 276.

Non-regulation provinces, in Inclia, 52.

Norfolk Island, I69.

North-Trest Teritories Canada), 77, 81, Apl. i.
Nova Scotia, 8, 77, 81-4, App. i.

Ontario, 77, 81-3, App. i.

Orders in Council, I 3 .

Ordinance, I 5.

Otaheite, imperial Act for trial of murders in, 143 .

Ottoman Dominions, capitulations in, I 5o, I 57, I 59-62.

Pacific, the, imperial Act for trial of murders in, I43, 145-6; protected islands in, 169 .

Pahang, 237.

Pardon, prerogative of. IIO-II, 227, 23 I, 265.

Parkes, Sir Henry, 84 .

Parliam॰nt, supremacy over British possessions, IO-12; legislation for self-governing colonies, 91 ; in Canada, 81, 199.

Parliamentary counsel to the Treasury, vi, xvi.

Parliamentary governmext, in colonies, 56.

Payment of members, 68.

Pearl fisheries, I 7.

Perak, 237.

Phillimore, quoted, I34, 140, I66, 168, I 8o.

Picton, General, trial of, 140.

Piracy, jurisdiction over, I 3O, I42.

Pitcairn Island, 169.

Plenary, not delegated, powers of colonial legislature, I6.

Port Phillip, 278, 284.

Possessions, British, defined, 2.

Presidencies, in India, 42 ; in Leeward Islands, 97.

President of the Council, Lord, I 3 . President of the United States, 56. Prince Edward Island, 77, 81, App.i.

Private intermational law, 125.

Private law, in colonies, 30.

Privy Council, appeal to Judicial Committee, 32-3, 88-9.

Privy Council of Canada, 59, 8I.

Prize courts, in colonies, 34 .

Probate of wills, 30.

Protective duties, 27.

Protectorate, British, definition, I65; exclusion of external relations, 166 ; from point of view of international law, 167-8; classification, I68-72; two types, I72 ; position of foreigners, I74-8; sovereignity divisible, I79-82; intermal suve- 
reignty, I $\delta_{3} ;$ courts and law, 185; African Orders, I $85-8$; Amatongaland Order, I 88 ; Fast Africa Order, IS9; Zanzibar Order, I90; Matabeleland $\mathrm{Or}^{-}$ ders, Igo; Southern Rhodesia Order, I90-I ; great extent of powers in these Orders, I9I-3; their legil basis. 191-5; Indian protectorates, 196.

Protestant marriages in Malta, 32.

Provinces, of India, 47 ; of Dominion of Canada, $81-4$, I 8,120 ; their powers of exclusive legis. lation, 200.

Provincial civil service, in India, 53.

Quebec, 77, 8I-3, App. i.

Queensland, defence force, 20; money Bills, 32 ; power of constitutional change, 74 ; constitution and legislature, App. i; foundation of colony, 276; early constitutional history, 29I-2.

Referendum, in Australia, 86.

Regulation provinces, in India, 52. Representative government, in colonies, 5-7, 94, 197.

Representative legislature, definition of, 239 ; may alter constitution, 240.

Reprieve, prerogative of, I $\mathrm{I}$.

Repugnancy, colonial law void for, 7I, I 2I, 240, 27 I, 286.

Reservation of Bills, 78, II3-2I, 281 .

Reserve power of governor of colony, $\mathrm{IO}_{4}$

Resident commissioner, 191.

Resident, in British protectorates, 173.

Resignation, of colonial member, 69.

Responsible government, 7-9; meaning of, 55 : informal origin of, 56 ; origin of, in Canada, 57-9.

Pupees, 29, 190.

Rupert's Land, 8I.

Russell, liarl, 57-8.

Russia Company, the, 149.

St. Jelena, 198.

St. Kitts, 97, 197.

St. Jucia, 98, 197.

St. Vincent, $98,197$.

Sarawak, British protectorate of, I 69-7I, 105.
Sark, subordinate to Guelnsey, 38 .

Scott, Mr: Hope, on consulin jurisdiction, 15I; his report reprinted, 242-66.

Sea fisheries, extra-territorial protection of, 147.

Seal-hunting, 26.

Secretary of State, for the Colonies, 4 ; for India, 43.

Selangor, 237.

Self-governing colonies, the problem stated, 54; responsible government, 55 ; its informal origin, 56 ; its origin in Camada, 57-9; unwritten constitutional custom, 59; rules as to money Bills, 6o; statutory definitions of position of executive, $6 \mathrm{I}-5$; the Upper House, 66; the Lower House, 67 ; comparison with imperial larliament, 68 ; limits to legislative power, 69; legislation must not be extraterritorial, 69-71; nor repugnant to laws of England, 71; powex to make changes in constitution, 72; in Australia. 73; in New Zealand, 74; in Canadil, 75 ; in Australian Commonwealth, 76 ; power to vary constitution of executive, $76:$ position of the Crown in legislation, 77 ; assent of governor, 77 ; his veto, 78 ; reservation and disallowance, 78 ; practical limits on inperial control,79; federiltions within the empire, 80 ; Dominion of Canada, $\delta_{1}$; parliament of Camada, 82 ; government of provinces, $8_{3}$; Austrialian federation, 84-6; the Commonwealth Act, 86-8; appeals to Privy Council, 88-9; federiations of Canada and Australia contrasted, 89-9o.

Semi-sovereign states, I66-7.

Senate, in Canada and Australia, 66.

Settled colonies, 5, 95 .

Seychelles, severed from Mauritius, 98, 197.

Sluanghai, I63.

Siam, consular juristiction in, 162 .

Sierra Leone, imperial Act for trial of offences in, $144,197$.

Simon, J. A., contributor of clity)ter iv, xxii.

Simon's liay, 21

Slave trule, $28,136,174,184$. 
Smuggling, in the Channel Islands, $39 ;$ in the Isle of Man, 40; extra-territorial jurisdiction, 147 ; in Africa, Orders in Council, I86.

Social influence, of governor of colony, 107.

Socotra, I69, I73.

Somali coast protectorate, I62, I69.

South Africa, imperial Act for trial of offences in, 144 ; commission of High Commissioner, 233-6.

South Australia, military force, 20 ; constitutional position of executive, 65 ; power of constitutional change, 74 ; constitution and legislature, App. i; foundation of colony, 276; early constitutional history, 288-9.

Southern Rhodesia Order in Council, I90-I.

Sovcreignty, limited to territory, I23: division of, I 53, I66, I79, 255.

Sphere of influence, defined, I.

States, of Australian Commonwealth. $87-9$.

Statute law consolidation, $x v$.

Straits Settlements, 95, I97-8.

Subordinate legislature, I6.

Suzerainty, 44 .

Tasmania, Defence Act, 20 ; constitution and legislature, App.i ; foundation of colony, 276, 278 ; early constitutional history, 289 .

Thring, Lord, note on Sir H. Jenkyns's early official career, xvixviii.

'Tobago, annexed to Trinidad, 98, I97.

Todd, Mr., quoted, 19, I04, 115 , I 20.

Tramsportation, 277.

'Ireason, outside territorial juriscliction, I 36, I 38 .

Treaties, as affecting colonies, 23-4; by Governor-General of India, 45,48 ; as basis of protectorates, I93.

'Trinidad, 98, I 97.

Tripoli, capitulations in, I 57, 252.

T'unis, capitulations abolislied, I.57, 175 .
'Turkey, capitulations in, I 50, I 57, I 59-62.

Turks and Caicos Islands, I 97.

Twiss, Sir Travers, quoted, 165-8, 183 .

Tynwald, Court of, 39 .

Uganda, 169.

United States, constitution of, 56, 90.

Unwritten constitutional custom, 59.

Upper Canada, 8I.

Upper housc, in colonial legislature, 66.

Utrecht, treaty of, 24 .

Van Diemen's Land. See Tasmania.

Veme, in criminal law, I26.

Veto of Bills, 78, I I 3-2 I.

Vice-Admiralty courts, 33-4.

Viceroy, of India, 44; warrant of appointment, 232-3; governor of a colony not a viceroy, IO2.

Victoria, money Bills, 6I ; constitutional position of executive, 63 ; power of constitutional change, 74 ; constitution and legislature, App. i ; foundation of colony, 276; early constitutional history, 286-8.

Virgin Islands, 97, 197.

Warrant of appointment, of Governor-General of India, 232-3.

Welby. Lord, testimony to Sir H. Jenkyns's official services, xxi.

West Coast of Africa, I 83 .

West Indies, forms of constitution, 96-7; federation, 97-8.

Western Australia, constitutional position of executive, 63 ; andmitted into Commonwealth, 88 ; constitution and legislature, App. i ; foundation of colony, 276,285 ; early constitutional history, 290.

Western Pacific, commission of High Commissioner, 236.

Wheaton, referred to, I31, I66-7.

Windward Islands, 98, 198.

Writs, in name of Crown, $3 \mathbf{r}$.

Zanzibar, I69, 190.

Zululand, 189, 234. 
UNIVERSITY OF CALIFORNIA LIBRARY

Los Angeles

This book is DUE on the last date stamped below.

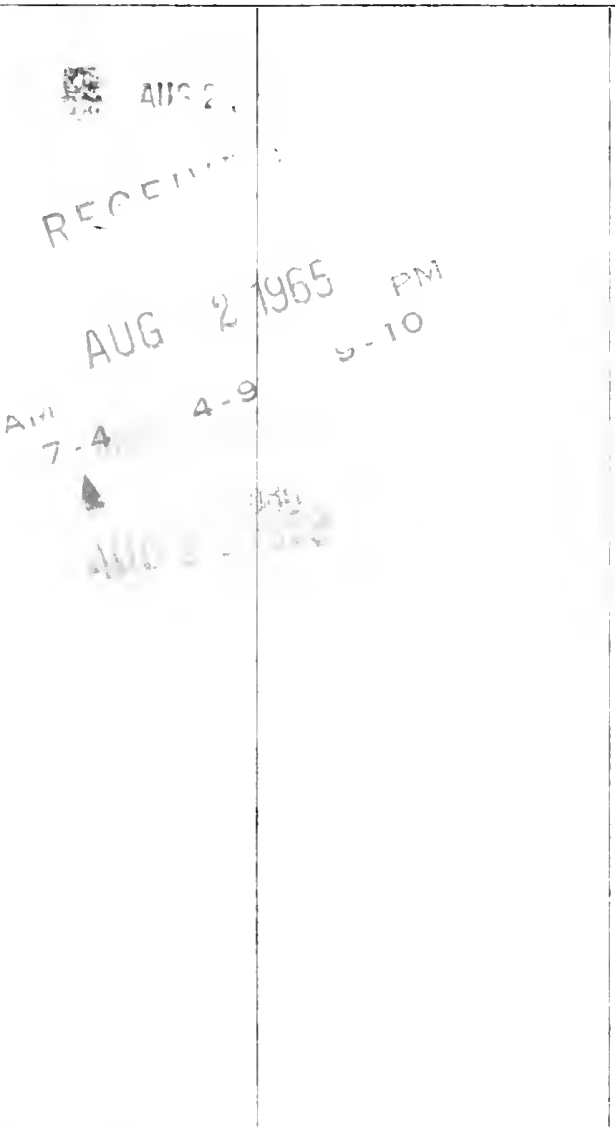

Form $1.9-10 m-6,52(A 1855) 444$ 


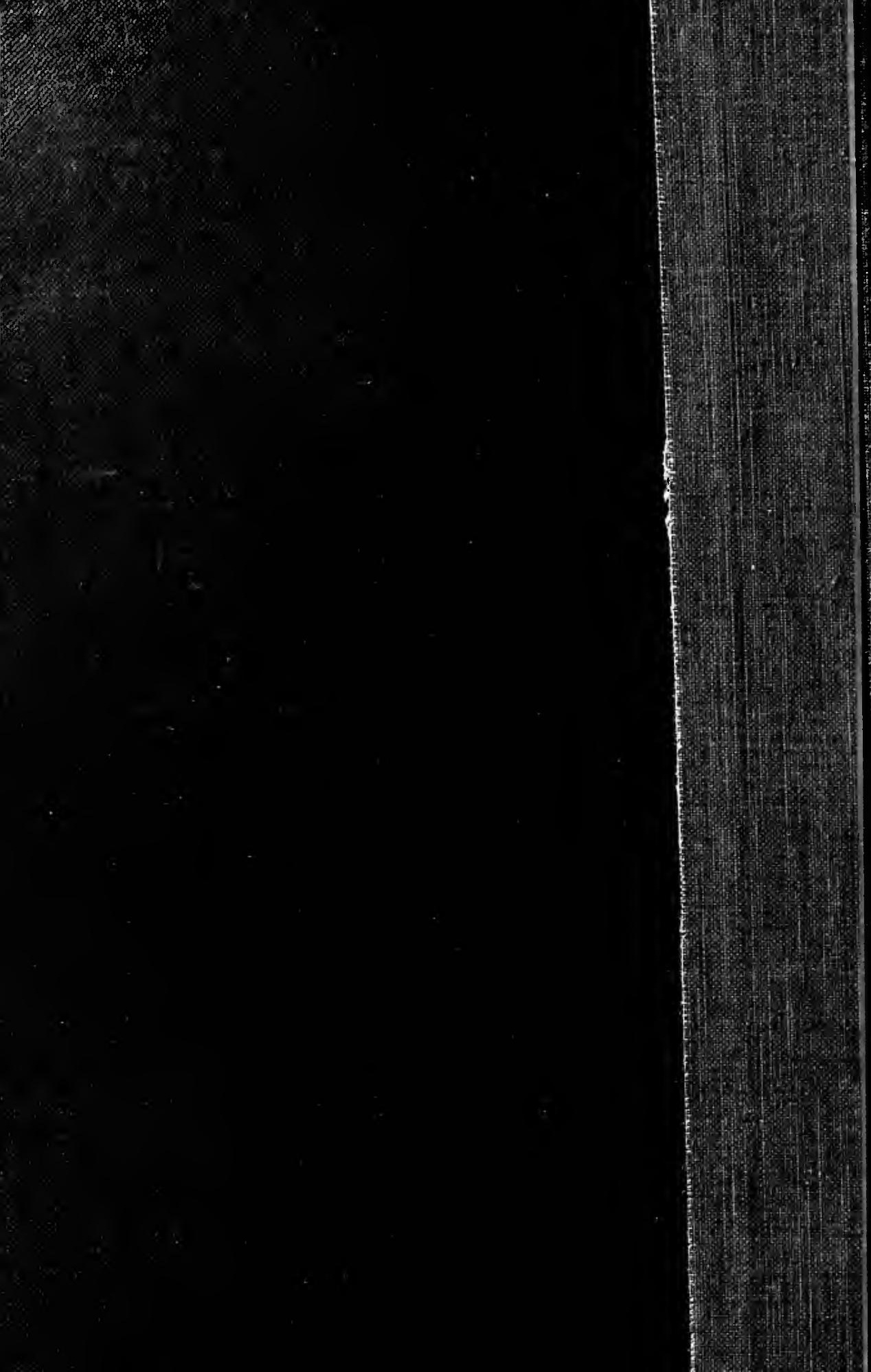

